EGIDIO VERTAMATTI

\title{
CONFORTO E DESCONFORTO DA COR DA ILUMINAÇÃO EM UMA CABINE DE AERONAVE: UMA ANÁLISE EXPERIMENTAL
}

Dissertação apresentada à Escola Politécnica da Universidade de São Paulo para obtenção do Título de Mestre em Engenharia Mecânica 
EGIDIO VERTAMATTI

CONFORTO E DESCONFORTO DA COR DA ILUMINAÇÃO EM UMA CABINE DE AERONAVE: UMA ANÁLISE EXPERIMENTAL

Dissertação apresentada à Escola Politécnica da Universidade de São Paulo para obtenção do Título de Mestre em Engenharia Mecânica

Área de Concentração:

Engenharia Mecânica de Energia e Fluidos

Orientador:

Jurandir Itizo Yanagihara 
Este exemplar foi revisado e corrigido em relação à versão original, sob responsabilidade única do autor e com a anuência de seu orientador.

São Paulo, 11 de março de 2014.

Assinatura do autor

Assinatura do orientador

FICHA CATALOGRÁFICA

Vertamatti, Egidio

Conforto e desconforto da cor da iluminação em uma cabine de aeronave : uma análise experimental / E. Vertamatti. -- versão corr. -- São Paulo, 2014.

$161 \mathrm{p}$.

Dissertação (Mestrado) - Escola Politécnica da Universidade de São Paulo. Departamento de Engenharia Mecânica.

1. lluminação 2. Aeronave 3. Cor 4. LED 5. Conforto ambiental I. Universidade de São Paulo. Escola Politécnica. Departamento de Engenharia Mecânica II.t. 
Agradecimentos

Ao

Professor Dr. Jurandir Itizo Yanagihara, pelo seu apoio, incentivo e competência.

À minha amada esposa que muito me incentivou e apoio para a conclusão desse mestrado

À equipe de apoio para a realização desta pesquisa.

Ao grupo de voluntários que participaram no ensaio dedicado

Ao grupo de passageiros que participaram dos ensaios pilotos.

À Embraer. 


\section{RESUMO}

Em uma viagem de avião os passageiros ficam de 1 a 12 horas em determinada localização, na maior parte do tempo sentados, com limitações nos ajustes de seus assentos, expostos a ruídos, vibrações mecânicas, temperaturas desconfortáveis, condições que podem levá-los a um processo de estresse em função do desconforto a que estão sujeitos. Outro fator importante para a sensação de desconforto é a qualidade e a cor da iluminação do interior da aeronave. A cor de uma iluminação tem influência no estado de humor das pessoas, que pode afetar de maneira positiva ou negativa o seu estado emocional. Com o avanço tecnológico e a invenção LED (Light Emitting Diode, Diodo Emissor de Luz) pode-se criar uma iluminação no interior da cabine, com cores que podem ser alteradas facilmente e dessa maneira influenciar o estado emocional dos passageiros. O objetivo da presente pesquisa é determinar a sensação de conforto/desconforto causada pela cor da iluminação em uma cabine de aeronave. Foi realizada uma pesquisa bibliográfica para se obter dados sobre a influência das cores no estado emocional das pessoas. Também foi pesquisado o mecanismo de funcionamento do sistema visual humano e como percebemos as informações visuais. A pesquisa foi realizada com uma população representativa de passageiros de aeronaves. Fez-se um levantamento quantitativo de aspectos subjetivos da percepção da qualidade do ambiente em função da cor da iluminação, por meio da aplicação da técnica do diferencial semântico. O ambiente de estudo desta investigação foi um mockup que reproduz o interior de uma cabine de aeronave em condições semelhantes a uma viagem de avião. Avaliou-se a influência de algumas características físicas dos passageiros, tais como gênero, cor dos olhos e Índice de Massa Corporal (IMC), na percepção da qualidade do ambiente em função da cor da iluminação. Os resultados das análises mostraram que as sensações percebidas do ambiente são afetadas pelas características físicas dos indivíduos, com diferenças significativas de percepção da qualidade do ambiente entre o sexo masculino e o feminino, entre $\mathrm{IMC}>25$ e IMC $<25$, e entre olhos claros e olhos escuros. Pela análise dos resultados também se determinou cores mais adequadas para reduzir o estresse de uma viagem de avião e para cada fase do voo. O resultado encontrado apresentou um grau de incerteza elevado, com desvio padrão de 20 pontos em uma amplitude de valores de 0 a 100, o que evidencia a subjetividade das percepções. Este resultado revela que o ideal, em termos de conforto da cor da iluminação, é individualizar a iluminação. Além das possibilidades práticas de aplicação em cabines de aeronave, o resultado obtido poderá se estender a outras aplicações, em que se busca o bem estar propiciado por uma cor de iluminação adequada.

Palavras-chaves: iluminação, conforto, cor, aeronave, led. 


\section{ABSTRACT}

On a plane trip passengers could stay from 1 to 12 hours in a specific location, most of the time sitting with limitations related to the settings of their seats, subjected to noise, vibration, uncomfortable temperatures, conditions that can lead them to a stress due to the discomfort process that they are exposed. Another important factor for the discomfort factor is the quality and color of aircraft interior illumination. The color of illumination influences the people's mood, which can positively or negatively affect their emotional state. With technological advancement and invention of LED (Light Emitting Diode) it is possible to create a lighting inside the cabin with colors that can be changed easily and thus influence the passengers' emotional state. The aim of this research is to determine the sense of comfort / discomfort caused by the lighting color in an aircraft cabin. A literature survey was conducted to obtain data about the influence of colors on people's emotional state. It was also investigated the mechanism of functioning of the human visual system and how we perceive visual information. The survey was conducted with a representative sample of passenger aircraft. It was made a data collection about subjective aspects of the environment perception due to the illumination color by applying the technique of semantic differential. The study environment of this research was a mockup that reproduced the interior of an aircraft cabin in conditions similar to a plane trip. It was assessed the influence of some physical passengers characteristics, such as gender, eyes color and body mass index (BMI), in the perception of the environment due to the illumination color. The analysis of the results showed that the perceived sensations of the environment are affected by the physical characteristics of the persons, and that there were significant differences in perception of the environment between male and female, between $\mathrm{BMI}>25$ and $\mathrm{BMl}<25$, and between light eyes and dark eyes. Through the analysis of the results it was also determined most appropriate colors to reduce the stress of traveling by plane and for each phase of flight. The results founded showed a high degree of uncertainty, with a standard deviation of 20 points in a range of values from 0 to 100 , which demonstrates the subjectivity of perceptions. This result reveals that the ideal, in terms of comfort lllumination color, is to individualize the lighting. Apart from the practical possibilities of application in aircraft cabins, the result can be extended to other applications where one seeks the well being brought by a color proper lighting is seek.

Keywords: lighting, comfort, color, aircraft , led 


\section{SUMÁRIO}

1 INTRODUÇÃO

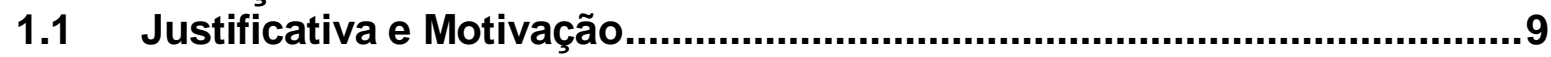

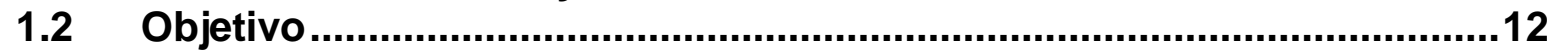

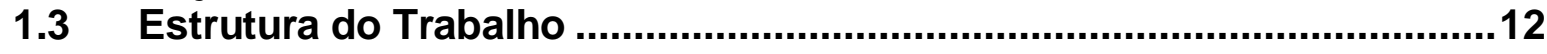

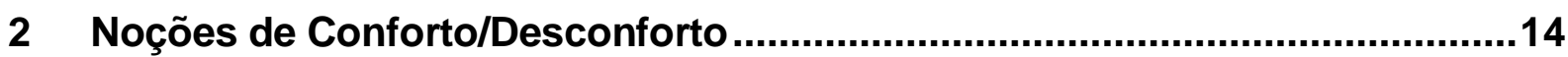

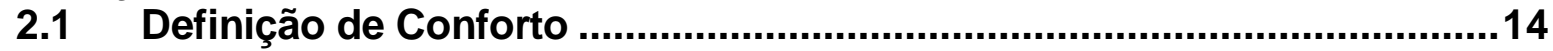

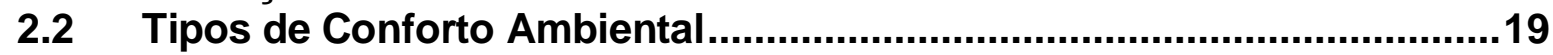

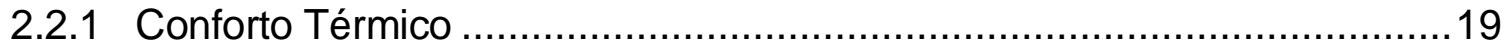

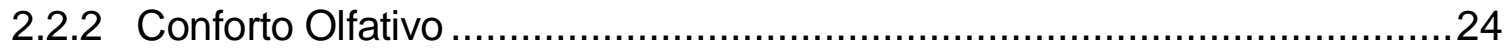

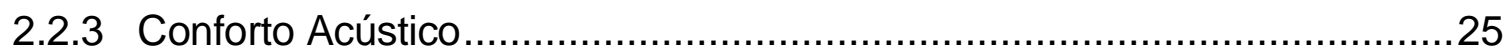

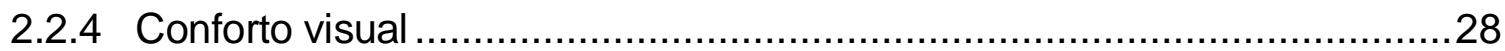

3 Influência da Cor e da lluminação na percepção de Conforto e Desconfort 31

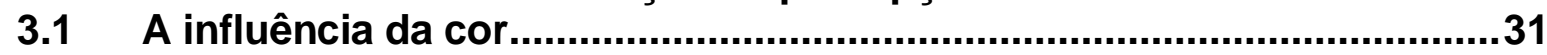

3.1.1 Conceitos básicos da Cor e sua percepção...........................................32

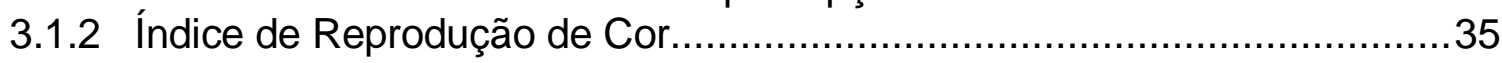

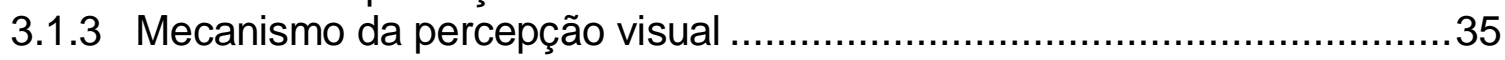

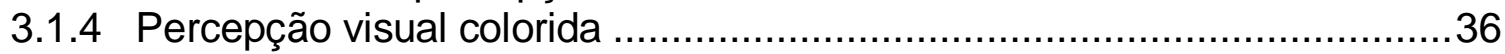

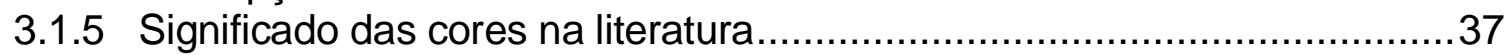

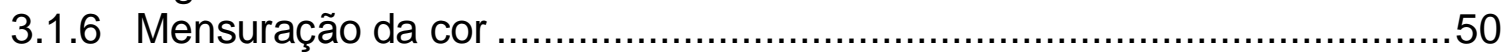

3.2 Influência da lluminação na sensação de conforto..................................53

3.2.1 Condições de lluminação que podem causar desconforto.........................54

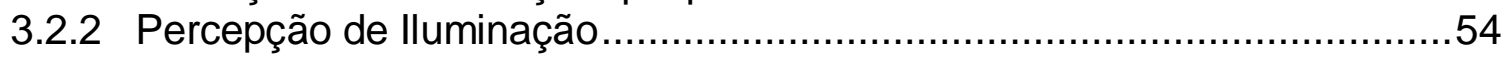

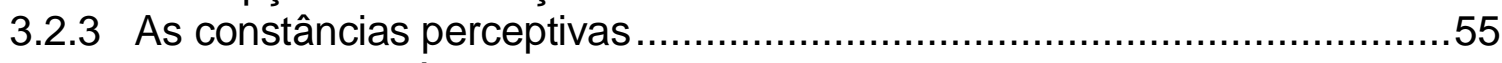

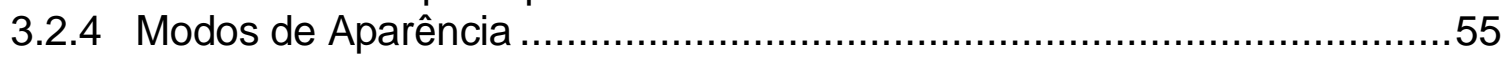

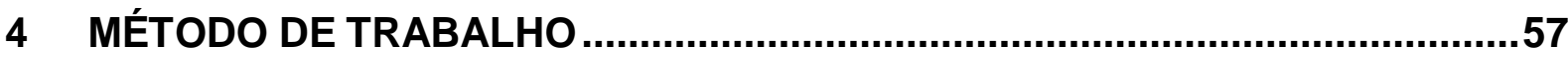

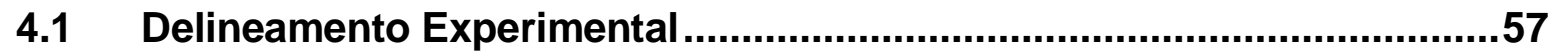

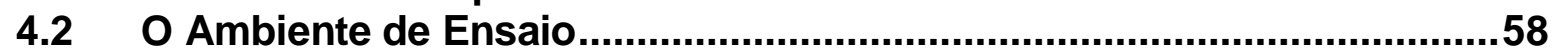

4.3 Estudo de Diferencial Semântico .........................................................63

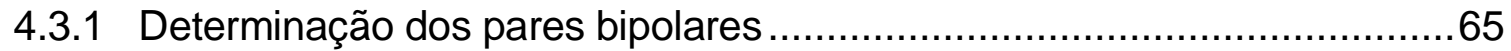

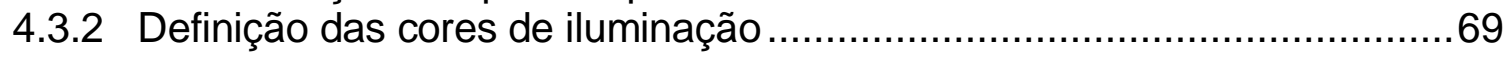

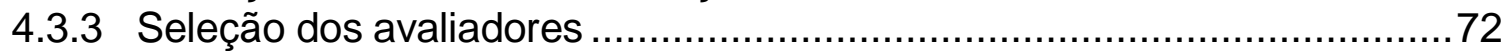

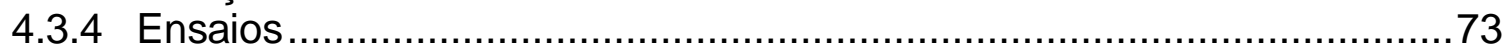

4.3.5 Preparação para a análise dos resultados ............................................73

5 RESULTADOS DOS ENSAIOS ..................................................................75

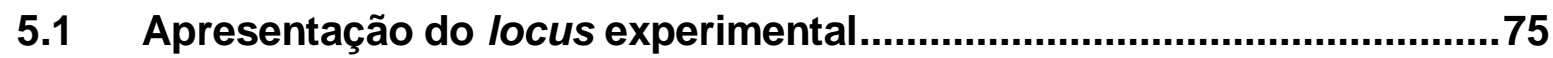

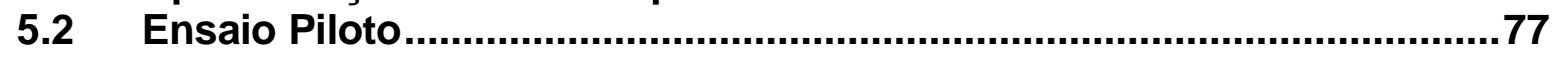

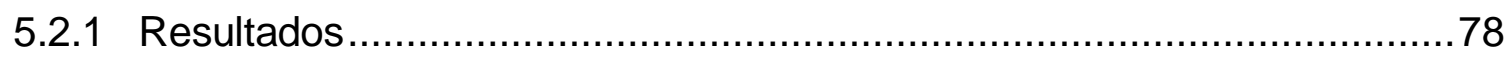

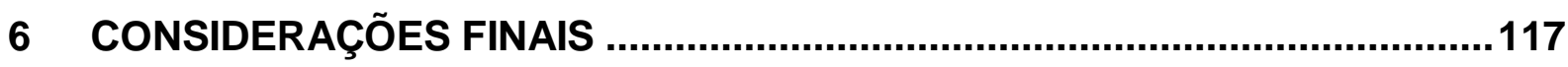

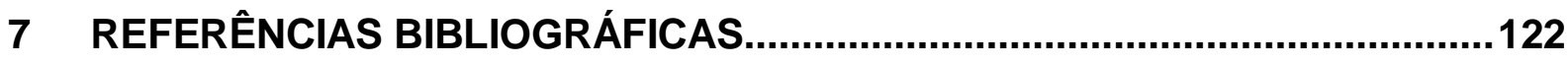

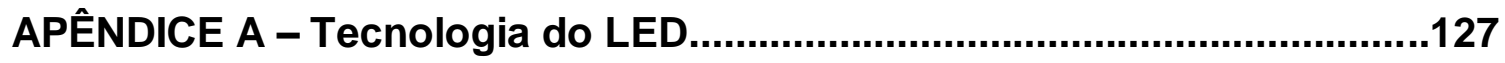

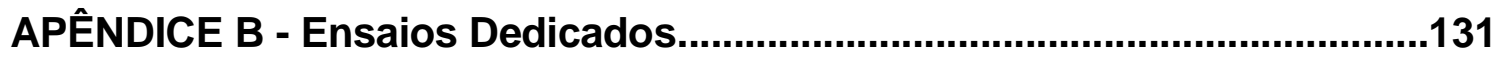

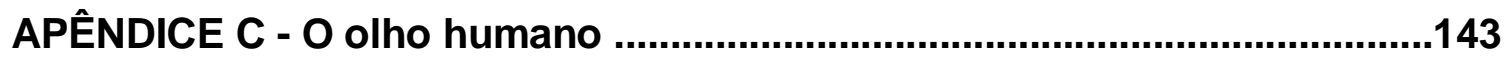

ANEXO 1 - Significado das cores em diferentes culturas...........................158 


\section{INTRODUÇÃO}

Uma das principais características da atual sociedade é a condição de mudança contínua, principalmente tecnológica, a qual exige dos indivíduos e empresas adaptações aos novos padrões decorrentes dessas transformações.

Esse fenômeno de alterações em ritmo acelerado e em modo perpétuo, característico da sociedade moderna, provoca transformações gradativas e significativas no individuo, na sua maneira de agir, no seu modo de interagir com o meio ambiente, na sua maneira de sentir e de perceber o mundo e as pessoas ao seu redor. A velocidade dessas transformações faz com que o homem deixe de perceber e refletir a respeito de como as modificações afetam seu estado emocional, sua saúde e sua disposição física, resultando o que Duarte (2010) denomina de anestesia dos sentidos.

O fluxo intenso e complexo de atividades que ocorrem na vida do homem leva-o a se adaptar ao ambiente em que vive sem que necessariamente elas the tragam o conforto necessário.

Nos grandes centros urbanos as pessoas passam a maior parte do tempo confinadas em escritórios, meios de transporte, no trânsito, diante de televisores e computadores. O ser humano é submetido a inúmeras ondas eletromagnéticas oriundas de sinais de estações de rádio, estações de televisão, celulares, aparelhos eletrônicos, além da poluição visual e de impactos da cor da iluminação. Esses fatores contribuem para um cansaço físico e mental que é ocasionado pelo desconforto nas suas várias formas: desconforto térmico, visual, acústico, vibracional, olfativo, tátil, ou ainda desconforto ocasionado pela influência da pressão atmosférica.

A cor da iluminação é outro elemento que pode originar condição de desconforto, principalmente em ambientes onde ela é produzida artificialmente. Um exemplo dessa condição é o interior de uma cabine de aeronave.

Em uma viagem de avião, os passageiros ficam de 1 a 12 horas na mesma posição, na maior parte do tempo sentados e com limitações nos ajustes de seus assentos, muitas vezes sujeitos a ruídos, a vibrações mecânicas e a temperaturas desagradáveis, condições estas que podem levá-los a um processo de estresse em 
função do desconforto a que estarão sujeitos. Durante a viagem vários fatores contribuirão para que esse estresse se intensifique, entre eles, o desconforto causado pela qualidade da iluminação, seja direta (para leitura) ou indireta (para iluminar o ambiente). A localização da luz direta pode ser um fator de escolha da poltrona. Em alguns assentos, em função da localização e direcionamento da luz dos spots, podem aparecer sombras que dificultam a leitura e a escrita. Há ainda outros fatores causadores de desconforto de iluminação, como: cor da luz, cor dos objetos, contrastes de cores e luminosidade, brilho, intensidade luminosa, temperatura de cor da luz, reflexo e textura dos objetos, ângulo de incidência da luz nos objetos e nas pessoas, espectro da luz, distribuição espacial da luz. Todos esses fatores contribuem de alguma maneira para que a situação "desconforto" do passageiro se instale.

Além do nível de lluminância, outros fatores, tais como contraste, tamanho do objeto, luminosidade, o tempo disponível para visualização ou reconhecimento dos objetos, determinam a visibilidade de um objeto dentro do campo visual. Outras considerações incluem desconforto devido ao ofuscamento, aos reflexos especulares e às sombras. Do ponto de vista subjetivo, a estética da cor, e os efeitos psicológicos da cor da iluminação também devem ser considerados. Esses fatores estão inter-relacionados e devem ser analisados durante o processo de seleção de níveis de iluminação, mas não quantificados separadamente.

Pergunta-se, então, que cores de iluminação em cabines de avião, seriam adequadas às distintas situações que ocorrem durante uma viagem aérea - Embarque, Cruzeiro, Serviço de Bordo e Desembarque, de modo que o passageiro se sinta confortável?

\subsection{Justificativa e Motivação}

De acordo com a organização $\mathrm{ABS}^{1}$ (American Bureau of Shipping, Escritório Americano de Navegação), as recomendações para a iluminação do ambiente em que os passageiros de embarcações se encontram, devem facilitar o conforto visual, atender adequadamente as atividades dos passageiros e auxiliar na criação de um ambiente visual apropriado. O projeto de iluminação envolve a integração desses

\footnotetext{
${ }^{1}$ A missão da ABS é servir ao interesse público, promover segurança de vida, de propriedade e do meio ambiente por meio do desenvolvimento e da verificação de normas para construção, projetos e manutenção de itens relacionados à marinha.
} 
aspectos a fim de fornecer iluminação adequada para o conforto e bem-estar dos passageiros (ABS, 2001).

McCafferty e McSweeney, respectivamente gerente e consultor, em 2001, de Avaliação de Segurança e Fatores Humanos do grupo de tecnologia do ABS, mencionam no artigo conjuntamente elaborado, Comfort: Passengers, Crews and Fast Ferries (ABS, 2001), que é necessário incluir critérios de iluminação como parte de um conjunto de parâmetros a ser considerado no projeto e planejamento dos requisitos de conforto de um ambiente.

De acordo com as diretrizes de Visão/ Missão/Valores das companhias aéreas brasileiras viajar de maneira confortável é uma meta almejada pelas companhias aéreas e, possivelmente, um componente que contribui para a solidez da imagem da empresa. A AZUL tem como valor a inovação, foco nos clientes e como visão fazer das viagens aéreas algo mais humano. A GOL tem como visão ser a melhor companhia aérea para viajar, foco no cliente e em inovação. A TRIP tem como valor a excelência de serviços ao cliente: busca constante de melhorias e satisfação. $A$ PASSAREDO tem como missão oferecer condições para que as pessoas viajem com o máximo de conforto, como valor busca desenvolvimento. A TAM tem como missão ser a companhia aérea preferida das pessoas e com criatividade.

Muitas das companhias aéreas que se mantém no mercado procuram oferecer a seus passageiros qualidades associadas ao conforto no atendimento, nos serviços prestados e na infraestrutura, a fim de satisfazer e conquistar o público que as procuram. A cor da iluminação é uma característica que traz inovação e se enquadra nas diretrizes de Visão/ Missão/Valores das companhias aéreas.

Além disso, parte-se do pressuposto que podem ser encontradas características de iluminação das cabines de avião que contribuam para um maior conforto da viagem.

Com os avanços e facilidades tecnológicas, o nível de exigência para atingir um grau elevado de satisfação, por parte do consumidor, mudou. As empresas procuram oferecer um conjunto de qualidades em seus produtos para garantir sua competitividade no mercado. Valores como funcionalidade, confiabilidade, custo são acrescidos de outros quesitos como conforto, satisfação e utilidade (YAMADA e 
PRICE, 1991). Portanto, conceitos de prazer, conforto são considerados fatores de competitividade.

Ao lado do desenvolvimento econômico das últimas décadas, crescem também as vítimas da globalização e os efeitos do sistema competitivo. Nesse tecido social, histórico e político, as exigências dos consumidores vão além do "estar bem", a demanda volta-se para o conforto (BROEGA, 2007, p. 1). Como consequência, "compreender e satisfazer as necessidades dos consumidores de forma rápida" (BROEGA, 2007, p. 3) é fundamental para que a empresa se mantenha no mercado competitivo. Dessa maneira, o conforto tornou-se elemento crucial para vários setores da sociedade - indústria têxtil, automobilística, aeronáutica, de calçados, de iluminação, entre outras.

Os diversos estudos que foram feitos nessa área - conforto de iluminação - são específicos para uma determinada população amostral, como, por exemplo, o estudo conduzido por Newsham et al. (2004), que envolveu 118 pessoas para participarem de um dia de experimento, em uma sala protótipo, onde se avaliou o humor, a satisfação e o desconforto causados por diferentes condições de iluminação.

O que motiva este estudo é a falta de parâmetros brasileiros para definição de níveis de conforto/desconforto causado pela cor da iluminação em uma cabine de aviãoDestaca-se a necessidade de investigar um padrão de conforto que atenda o público brasileiro usuário do avião como meio de transporte. Para tanto, foi necessário fazer um levantamento estatístico com uma população representativa da classe de passageiros.

Os resultados obtidos neste estudo, de determinação de desconforto causado pela iluminação podem contribuir para que as pessoas tenham maior predisposição para viajar, sabendo que estarão em um ambiente agradável. Com a redução de estresse causado pelo desconforto da cor da iluminação, as viagens tornar-se-ão mais agradáveis ao passageiro incentivando-o a procurar as companhias aéreas que ofereçam esse diferencial. 


\subsection{Objetivo}

O objetivo da presente pesquisa é avaliar o grau de conforto/desconforto que a cor da iluminação causa aos passageiros e com esta informação determinar cores de iluminação de cabines de aeronaves que minimizem o desconforto provocado pela iluminação do interior da aeronave.

\subsection{Estrutura do Trabalho}

Para esta pesquisa foi feito um levantamento quantitativo envolvendo aspectos subjetivos.

Neste estudo consideram-se dois tipos de variáveis: independentes e dependentes. De acordo com Boente e Braga (2004, p. 5), e Dancey e Reidy (2007, p. 33), as variáveis independentes são aquelas manipuladas pelo pesquisador. Vergara (2004,

p. 48) define variável dependente como sendo aquela que é afetada pela independente.

Como variáveis independentes apontam-se os aspectos da luz, cor, espectro, intensidade, temperatura de cor e o tempo de exposição.

Considera-se como variável dependente as respostas das pessoas que participaram da pesquisa do questionário a ser utilizado na avaliação das impressões do ambiente iluminado.

As respostas ao questionário podem ser afetadas pelas características físicas do passageiro, tais como, idade, sexo, peso, altura, cor dos olhos. Outro fator que também pode afetar as respostas dos questionários é o estado emocional em que a pessoa se encontra.

Os dados subjetivos, obtidos por meio das informações de sensação de desconforto fornecidas pelos passageiros, mediante um questionário elaborado para esse fim, foram pontuados e analisados para determinação do nível de desconforto que uma determinada iluminação proporciona. 
Este trabalho foi organizado da seguinte maneira: 1. Introdução, em que se apresenta o objeto de estudo desta pesquisa, bem como os objetivos traçados para 0 desenvolvimento do trabalho; 2. Noções de conforto/desconforto-- neste item, apresenta-se os conceitos empregados na investigação e os autores que serviram de base para desenvolver o estudo. Aborda-se também os diferentes tipos de conforto, assim como a caracterização do sistema visual e iluminação. Passa-se, em seguida para o item 3. Influência da cor e da iluminação no conforto desconforto. O item 4. Métodos de trabalho - refere-se à descrição dos procedimentos e critérios utilizados para a coleta de dados e sua organização. $O$ item 5. Resultados dos ensaios compõem-se da análise das informações obtidas dos questionários e estatísticas utilizados no decorrer do experimento. Por fim, no item 6 . Considerações finais - no qual são tecidas algumas reflexões a respeito dos resultados. 


\section{Noções de Conforto/Desconforto}

Após o texto introdutório, com a exposição do tema e questionamentos discutidos ao longo da pesquisa, passa-se, neste capítulo aos temas relativos à caracterização do conforto/desconforto.

\subsection{Definição de Conforto}

No caminho de aproximação com o tema conforto, uma quantidade considerável de abordagens a respeito do tema foi encontrada. Parte dos estudos explora o termo conforto em suas dimensões - social, funcional, física, e outra parte enfoca aspectos psicológicos implícitos em seu significado.

Em Pineau (1982), conforto corresponde a tudo o que contribui para o bem-estar e conveniência dos aspectos materiais da vida, portanto, constitui uma melhoria das condições de vida no espaço habitado. Para Lueder (1983), conforto é uma função dos benefícios e restrições físicas sobre a pessoa engajada em uma ou mais tarefas específicas, Slater (1985) vê conforto como um estado agradável de harmonia fisiológica, psicológica e física entre um ser humano e ao meio ambiente. Na visão de Zahang (1992), conforto está relacionado ao sentimento de bem estar e relaxamento e o desconforto está relacionado com questões fisiológicas e biomecânicas. Para Sanders e McCormick (1993), conforto é uma sensação e, por isso, depende, em parte, da pessoa que experimenta uma situação, Na concepção de Quehl (2001), conforto é um estado psicológico do bem estar subjetivo induzido sob condições ótimas) diferem entre si, mas os autores comungam o pensamento de que não há uma definição capaz de abranger todos os contextos em que o conforto ocorre (LINDEN, 2004, p. 73-74).

De acordo com Linden (2004), o tema "conforto" ganha importância no final da década de 1950 e continua sendo fator recorrente em vários estudos atuais. Na França, o tema conforto surgiu pela primeira vez na época medieval, ligado ao sentido de piedade e consolação. No renascimento, o sentido de auxílio ou assistência adquiriu mais importância e no início do século XIX, o significado de conforto passou a ser o de posse. Durante o romantismo, o termo foi extensivamente utilizado como sinônimo de 
bem-estar. Em 1949, de acordo com Pezeu-Massabuau (2012), o conforto moral e intelectual passam a fazer parte do cenário de bem-estar da mente e convivem com o sentido de "utilidade" e "vantagem". Atualmente o conforto e o bem-estar decorrente dele estão relacionados com conveniências intelectuais e materiais. No sentido moderno, pós-moderno ou doméstico, conforto é sinônimo de ciência domótica (tecnologia doméstica) (PEZEU-MASSABUAU, 2012, p.18-20).

O conceito atual de conforto emergiu durante o processo de transformação da sociedade desencadeado pela Revolução Industrial. A necessidade de obter utensílios, mobílias e aparatos que facilitariam a vida do ser humano, era característica de um grupo restrito. À medida que a ideia de conforto foi sendo introduzida às classes de menor poder aquisitivo, desenvolveu-se o desejo pela aquisição de bens materiais, que, ao lado da higiene, eram entendidos como sinônimo de conforto e modernização. As mudanças advindas da industrialização conduziram a uma reconfiguração de todos os setores da vida humana, hábitos, costumes, relações humanas e comerciais, organização do tempo e espaço (DUARTE, 2001, p. 47), elementos que favoreceram a instalação do capitalismo (MALDONADO, 1991, p. 35).

Maldonado (1991) traça uma relação entre conforto e qualidade de vida, a partir da ideia de "habitabilidade", cujo significado e concepção se alteram, de acordo com o contexto histórico, social e político em que está inserida.

Da mesma maneira, a definição e interpretação do conforto têm se alterado ao longo da história e retratam os valores que cada período e cultura estabelecem como válidos e representativos de sua maneira de estar e se relacionar com o mundo.

Outro aspecto do conforto trazido por Maldonado é sua "função compensatória" física e psicológica do conjunto de atividades diárias do mundo moderno, seja para reestruturar posturas corporais, relações familiares ou vida privada. Assim, o conforto se apresenta como modelo de vida burguesa, em que a família moderna é remodelada e cujo interesse se volta para o ambiente de privacidade, de intimidade, baseado, ao mesmo tempo, em necessidades materiais como ideal de conforto (MALDONADO, 1991, p. 36-37). 
Além dos aspectos positivos, o conforto pode ainda ser analisado a partir da relação de interdependência entre a sua manifestação e os resultados negativos surgidos da modernização, isto é, uma das consequências da difusão do conforto é o desconforto. Tome-se como exemplo, o congestionamento causado pelo excesso de veículos nas ruas e a consequente poluição advinda da queima dos combustíveis propulsores dos meios de transporte (MALDONADO, 1991, p. 35-36).

Avançando na investigação, encontra-se o conforto associado ao prazer. Nessa visão conceitual, o prazer, apontado por Jordan (1998), não está centrado apenas nas vantagens técnicas referentes a um produto, mas em fatores humanos desencadeados durante o seu uso. No entanto, a facilidade no uso de um produto não garante a "satisfação" do consumidor. É preciso que a usabilidade seja acompanhada de sentimentos positivos. De acordo com Jordan, é necessário que haja prazer na utilização de um produto (JORDAN, 1998, p. 25-26).

O autor define prazer como sendo os "benefícios emocionais e hedônicos associados ao produto" (JORDAN, 1998, p. 26) e o desprazer, como "as penalidades emocionais e hedônicas associadas ao uso do produto" (Idem). A análise dos dados coletados em sua pesquisa possibilitou elencar sentimentos relacionados ao prazer (segurança, confiança, orgulho, excitação, satisfação, entretenimento, liberdade, nostalgia) e também ao desprazer (aborrecimento, ansiedade, desprezo, resignação, sentimento de enganação, agressão). Apesar de Jordan reconhecer a importância da usabilidade, conclui que o eixo prazer e desprazer deve ser considerado na determinação de produtos agradáveis e desagradáveis (JORDAN, 1998, p. 28-33).

A questão do prazer também é abordada por Linden (2004), paralelamente à da emoção. Os produtos podem afetar emocionalmente o ser humano. Juntos, Linden e Guimarães trazem para o debate uma visão multidimensional de conforto, isto é, um fenômeno constituído de dimensão subjetiva e objetiva e propõem a seguinte definição: "conforto é uma sensação prazerosa de bem-estar físico e psicológico. $O$ conforto é também uma condição de bem-estar com ausência de dor, desconforto e estresse, definida a partir de uma situação de desconforto" (2004, p. 83). O autor considera o conforto como uma sensação que implica emoções de prazer. 
As reações psicológicas do homem em sua relação com objetos e ambientes são oriundas do sistema cognitivo e do sistema afetivo que ocorrem por meio das emoções. Os dois sistemas - cognitivo e afetivo -, apesar de diferentes, estão conectados e são influenciados um pelo outro (LINDEN, 2004, p. 49).

Claude Pineau, igualmente a Linden, considera a aproximação com o conforto por mais de uma via de pensamento (PINEAU, 1982, p. 271).

De acordo com esse autor, há duas maneiras de abordá-lo:

1. Uma, relacionada às necessidades fisiológicas, físicas, estilo de vida, em que a aquisição de bens materiais pode trazer satisfações momentâneas;

2. Outra associada às necessidades psicológicas, que são individuais, culturais, sociais, políticas e históricas (PINEAU, 1982, p. 276-279).

As análises de Pineau (1982) possibilitaram o surgimento de quatro elementos, significativos à percepção de conforto: personalização, liberdade de escolha, espaço e aconchego, são de grande relevância.

1. Personalização - é tornar um espaço próprio, é reconhecer-se nele, pois o indivíduo o organiza e decora de acordo com suas necessidades e vontade. A personalização possibilita a sensação de bem-estar e de cumplicidade entre 0 indivíduo e seu ambiente. O sentimento de pertencimento gera a sensação de liberdade em habitar um espaço em que se sente à vontade (PINEAU, 1982, 276-277).

2. Liberdade de escolha - é a liberdade do homem de escolher, de estar distante de intrusões alheias e, dessa forma, garantir-lhe a proteção; é a liberdade por optar pela calma, silêncio, relaxamento, pela reflexão. Ser livre implica em ter "a liberdade de ação", "a possibilidade de", quando se deseja (PINEAU, 1982, p. 277-278).

3. Espaço - é possuir um território próprio e, dessa maneira, intensificar a liberdade (PINEAU, 1982, p. 278-279).

4. Aconchego - é um fenômeno complexo, pois depende de fatores físicos e psicológicos. Seu significado está ligado ao bem-estar e ao prazer (PINEAU, 1982, p. 279). 
De acordo com Pineau (1982, p.274) não se chega à ideia de conforto somente a partir de critérios quantitativos e materiais, é preciso uma visão global, que permita estudar o conforto a partir das diferentes relações de seus elementos. Além disso, o conceito de conforto não é universal e "não pode ser definido em sentido absoluto e definitivo" (PINEAU, 1982, p. 282).

O termo "conforto" não tem uma única definição e pode estar relacionado a bem-estar, riqueza, charme, amabilidade, conveniência, felicidade, alegria, quietude, satisfação, aconchego eficiência, funcionalidade, prazer, praticidade, entre muitos outros significados.

Outro autor que apresenta o conforto em diferentes dimensões é Slater (1986). O autor, citado por vários pesquisadores indica três tipos de conforto:

- "conforto fisiológico" - "relacionado com a capacidade que o organismo humano tem de manter a vida".

- "conforto psicológico"- relacionado com a capacidade da mente humana, se manter a funcionar satisfatoriamente com ajuda externa,

- "conforto físico"- que é o efeito do ambiente externo sobre o organismo humano"

Este estudo é desenvolvido a partir das perspectivas de Pineau (1982) e Slater (1985, 1986), que veem a questão de conforto/desconforto relacionada às necessidades fisiológicas, físicas e psicológicas do indivíduo

O conforto implica em percepção subjetiva de diferentes sensações, fato que the confere característica multifacetada, pois abrange os diferentes sentidos do ser humano - audição, tato, visão, olfato. Além disso, as percepções subjetivas de um indivíduo dependem de vários fatores, entre eles suas experiências passadas, que influem nas experiências presentes e elaboram sua própria definição de estado de conforto.

A percepção subjetiva do conforto requer ferramentas de análise da psicologia sensorial, que é composta pelos cinco sentidos - visão, audição, olfato, gosto e tato, e pelas ramificações de cada um desses componentes (2007, p. 110). 


\subsection{Tipos de Conforto Ambiental}

O homem se relaciona com o mundo por meio dos sentidos - visão, olfato, tato, audição, paladar. As informações recebidas de experiências externas são traduzidas primeiro na forma de sensações. O corpo tem papel de comunicação com o tempo e espaço e pela experiência corpórea, vivenciada por meio dos sentidos, que se dão as diferentes maneiras de apreensão do mundo (MERLEAU-PONTY, 1971). Cada um dos sentidos percebe os fenômenos segundo suas possibilidades e características próprias, além de estabelecerem relações entre si ao experenciarem determinada situação, e dão diferentes significados às informações recebidas, sejam elas visuais, táteis, auditivas, olfativas ou gustativas. Estas informações, se transpostas para o tema do conforto/desconforto, podem motivar discussões a respeito de determinação de produtos e experiências confortáveis ou desconfortáveis.

\subsubsection{Conforto Térmico}

Conforto térmico, conforme definido pela norma ASHRAE 55-2010, "é um estado de espírito que reflete satisfação com o ambiente térmico que envolve a pessoa e é ponderado por avaliações subjetivas" (ASHRAE Standard 55-2010).

$\mathrm{Na}$ determinação da sensação de conforto térmico, um dos fatores que possui maior significado é a temperatura. O metabolismo do corpo humano mantem a temperatura interna dentro de uma faixa muito estreita. Uma variação de $1^{\circ} \mathrm{C}$ é suficiente para criar desconforto. Como a variação da temperatura externa é relativamente alta, nem sempre o sistema regulatório da temperatura do corpo humano consegue manter o organismo na faixa de conforto. No processo de estabilização da temperatura interna do corpo humano há geração de calor, o qual deve ser dissipado no ar e nas superfícies que estão ao seu redor. Quando a temperatura externa for relativamente alta e houver dificuldade na troca térmica entre o corpo e o meio ambiente, sente-se uma sensação de calor, o que leva a uma sensação de desconforto. Por outro lado, quando a temperatura externa for relativamente baixa, a perda de calor é rápida, gerando, consequentemente uma sensação desconfortável de frio.

Além da temperatura do ar, existem outros fatores que atuam na sensação de conforto térmico, tais como: 


\subsubsection{Diferença nas Temperaturas das Superfícies e do $\mathrm{Ar}$}

$\mathrm{Na}$ determinação do conforto térmico, emprega-se temperatura operativa ("temperatura de um meio imaginário com o qual a pessoa troca a mesma quantidade de calor por convecção e radiação que aquela trocada com o meio real", ASHRAE 55 2010), que é uma função da temperatura radiante média (" temperatura uniforme de um ambiente imaginário no qual a troca de calor por radiação é igual ao ambiente real não uniforme", ASHRAE 55 2010) e da temperatura do ar. Porém, existe dificuldade na determinação dessa temperatura, uma vez que a pessoa normalmente se movimenta e a influência das paredes é alterada.

A sensação de desconforto aparece quando há diferenças de temperatura das paredes, conforme indicado na Figura 2.1, a qual representa a porcentagem de pessoas que sentem sensação de desconforto em função da diferença de temperatura de uma superfície em relação às outras superfícies. Observa-se na Figura 2.1 que assimetrias de temperaturas do teto são mais significativas em relação às outras paredes, e que paredes mais frias apresentam melhores condições de conforto. Também ocorre sensação de desconforto quando a temperatura do ar nos pés for diferente da temperatura do ar na cabeça. A Figura 2.2 indica a porcentagem de pessoas que sentem desconforto em função da diferença da temperatura do ar entre os pés e a cabeça e quanto maior for esta diferença de temperatura maior será o desconforto.

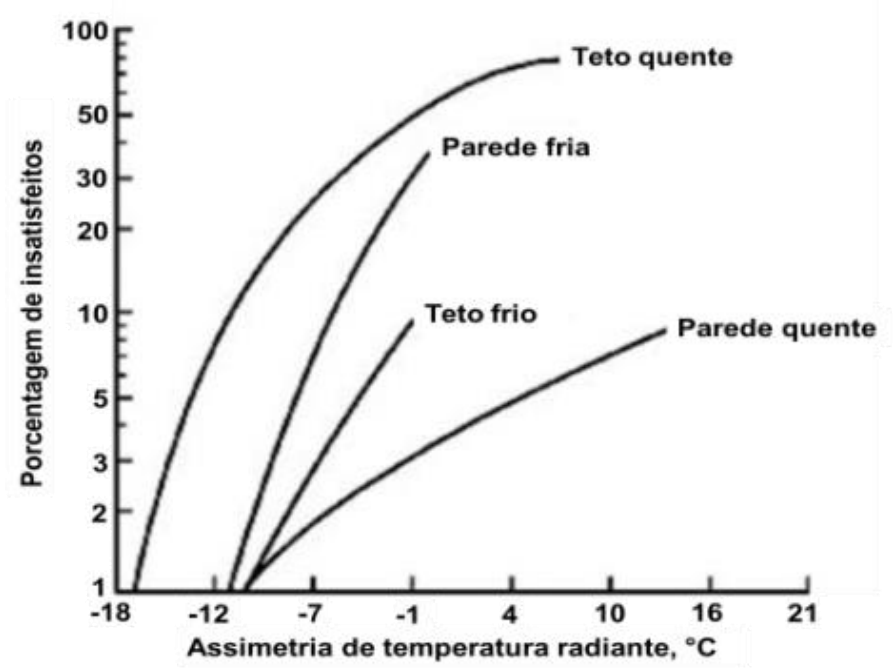

Figura 2.1 Porcentagem de pessoas que expressam desconforto devido à radiação assimétrica (ASHRAE 2009, p. 183). 


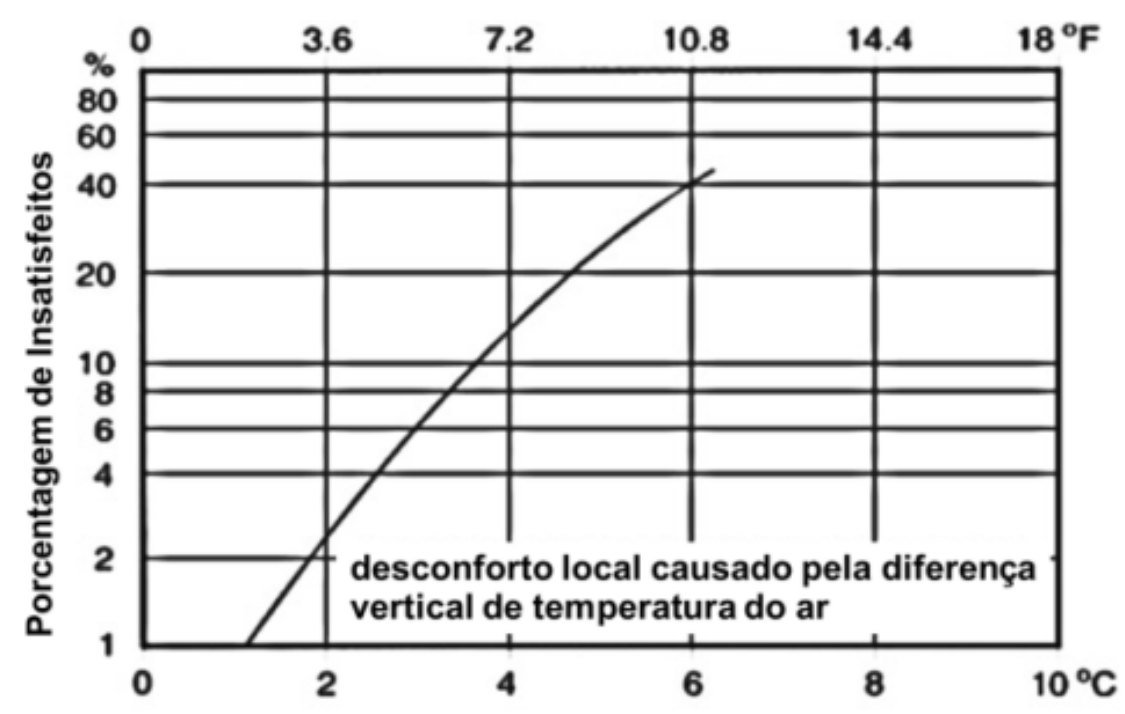

Diferença da temperatura do ar entre a cabeça e os pés

Figura 2.2 Desconforto local causado pela diferença de temperatura vertical (ANSI/ASHRAE-55, 2010).

\subsubsection{Umidade Relativa do $\mathrm{Ar}$}

Outro fator importante que influencia na sensação de desconforto térmico é a umidade relativa do ar. Valores elevados de umidade relativa do ar prejudicam a evaporação do suor e não permitem o resfriamento adequado do corpo. Consequentemente, a temperatura aumenta ligeiramente e cria a sensação de calor, que gera desconforto. Comprova-se também que com baixas temperaturas do ar e com altas taxas de umidade relativa do ar, a sensação de frio torna-se mais intensa (ROSET, et al.). Pelo fato do ser humano não ser muito sensível às variações de umidade do ar, a faixa de umidade relativa do ar que propicia conforto é ampla, entre 30\% e 65\% (NBR 164012 2008). Com valores de umidade acima de $65 \%$, sente-se sensação de desconforto pelos seguintes motivos:

- pela não evaporação da umidade da pele (ASHRAE, 2009, p. 9-12).

- pelo aumento de atrito entre a pele e a roupa,

- pelo fato da pele estar mais úmida (ASHRAE, 2009, p. 9-12).

Para umidade relativa do ar abaixo de $30 \%$, sente-se uma sensação de desconforto no sistema respiratório. Na Figura 2.3, baseada no ASHRAE 55-2010, o interior dos poliedros correspondem às zonas de conforto relacionadas à umidade relativa do ar $\mathrm{e}$ à temperatura operativa, mostrando-se duas figuras sendo a com contorno azul (linha continua) correspondente ao períodos de inverno e a com contorno laranja (linha 
tracejada) para períodos de verão, sendo que a velocidade do ar deve ser menor do que $0,20 \mathrm{~m} / \mathrm{s}$.

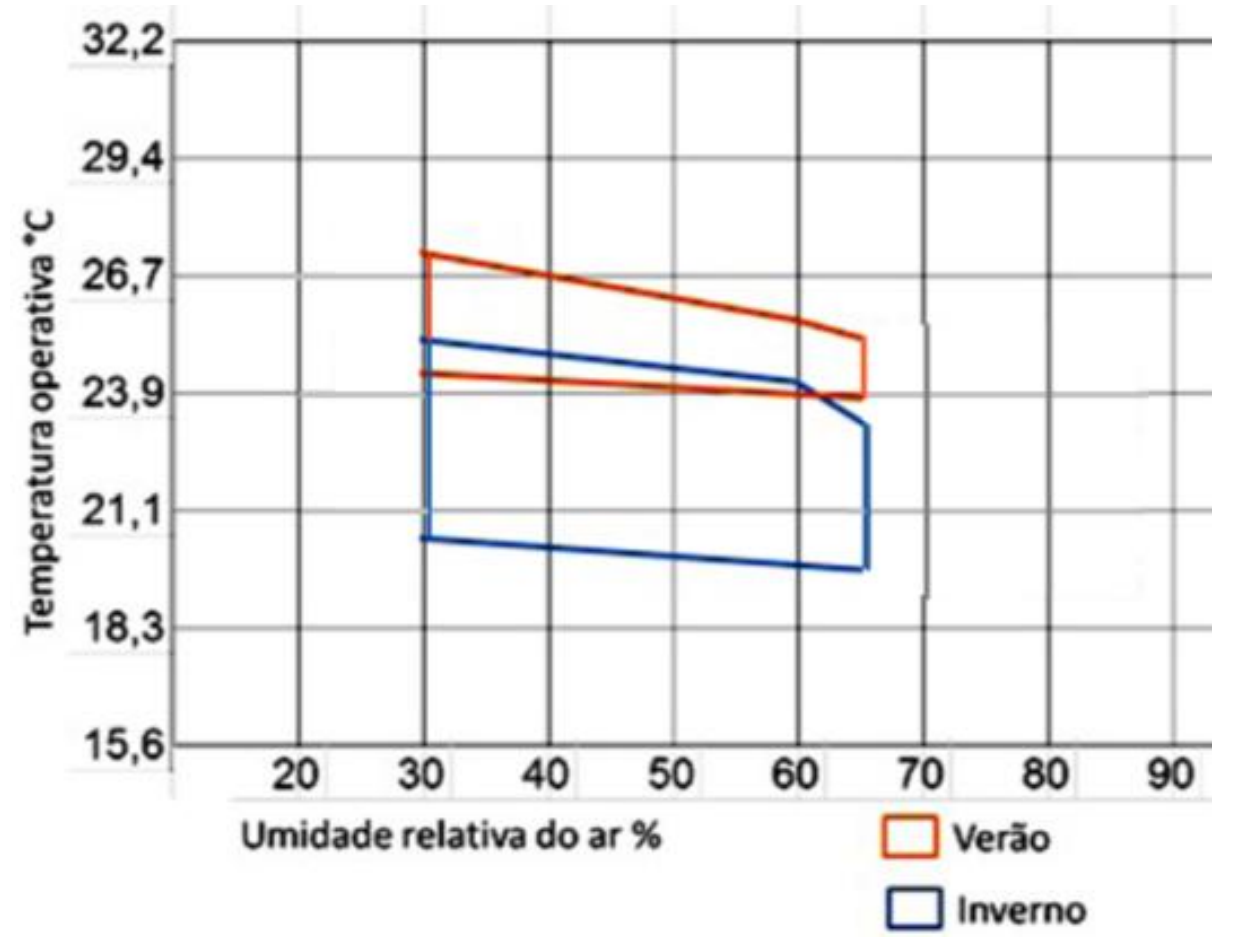

Figure 2.3: Faixa aceitável de conforto relacionada à umidade relativa e à temperatura operativa (baseado na ASHRAE, 2010).

\subsubsection{Velocidade do $\mathrm{Ar}$}

A percepção do conforto térmico também é afetada pela velocidade do ar. A movimentação do ar pelo nosso corpo acelera o processo de evaporação do suor, o que é favorável para o conforto térmico em dias quentes, $T_{\mathrm{ar}}<35^{\circ} \mathrm{C}$. O processo de troca de calor do corpo com o ar por convecção e evaporação torna-se mais eficaz quanto maior for a velocidade do ar. Porém, em dias frios a velocidade do ar não é desejável, pois o processo de troca de calor, comentada anteriormente, fará com que a temperatura do corpo se reduza, o que causará sensação desconfortável de frio.

Ressalta-se que o conforto e desconforto dependem do conjunto velocidade média do ar e da temperatura do ar - acima de determinados valores é possível haver desconforto. Conforme a norma ASHRAE 55-2010, velocidades do ar acima de $0,8 \mathrm{~m} / \mathrm{s}$ não são recomendáveis. 
O gráfico da Figura 2.4 indica a porcentagem de pessoas que sentem desconforto em função da velocidade média do ar e de sua temperatura.

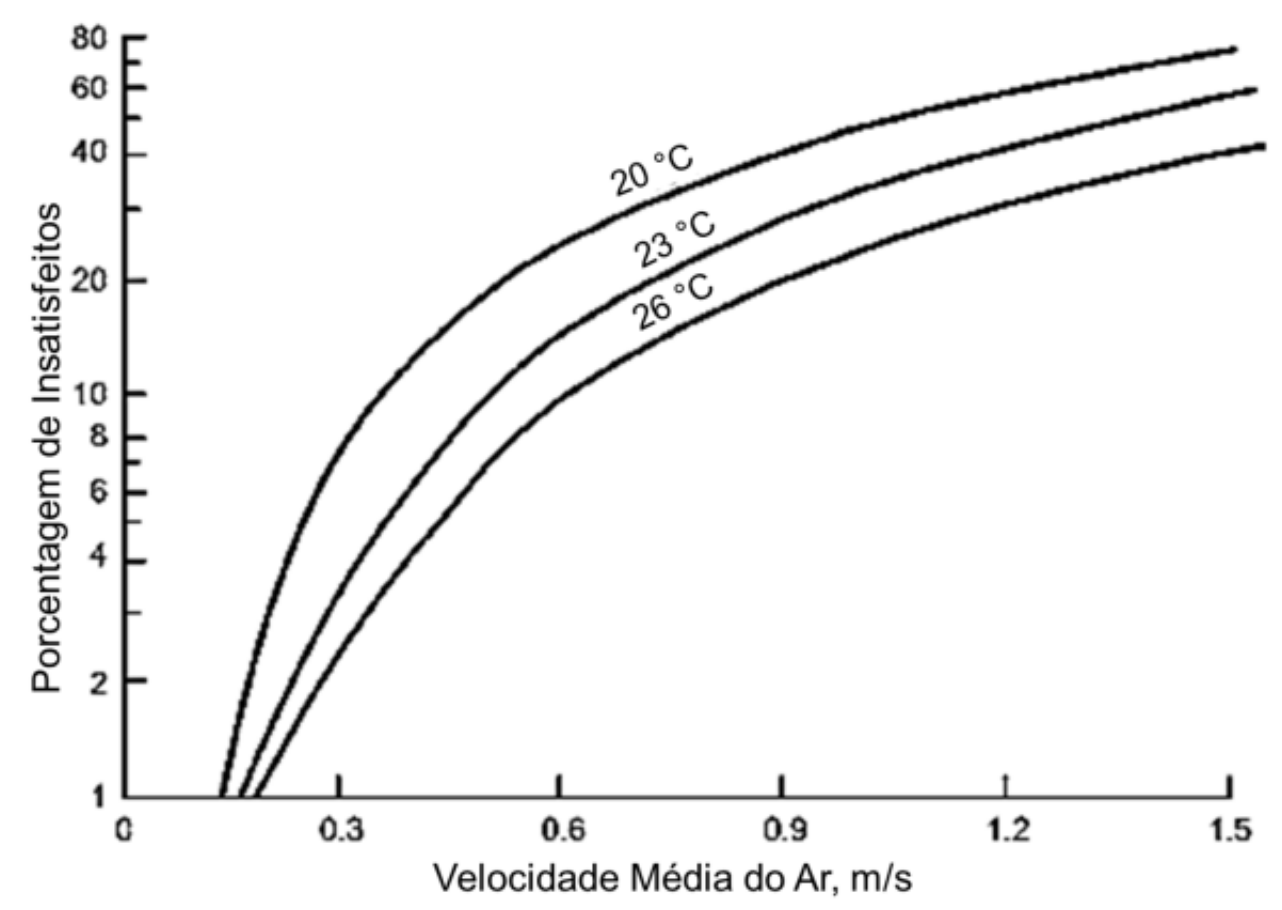

Figura 2.4 Porcentagem de pessoas insatisfeitas em função da velocidade do ar (ASHRAE, 2009, p. 183).

\subsubsection{Metabolismo}

A maior fonte de diferença na percepção de conforto térmico, no entanto, pode ser a individualidade de cada pessoa. O metabolismo do corpo humano é eficaz na regulação da sua temperatura, porém a eficácia em manter a temperatura do corpo varia de indivíduo para indivíduo. O metabolismo também é sazonal, se modifica em função de alguns fatores tais como atividade física, alimentação, idade, sexo, estado emocional e temperatura externa.

\subsubsection{Vestimenta}

A vestimenta também é um fator que pode propiciar conforto ou desconforto, dependendo do grau do isolamento térmico da mesma e do tipo de roupa. Em períodos quentes a vestimenta deve permitir a evaporação do suor e não ser um isolante térmico. Em períodos frios a vestimenta deve permitir a evaporação do suor e ser um isolante térmico. 


\subsubsection{Cor das superfícies}

A temperatura que percebemos pelo tato sofre alterações em função das cores empregadas no ambiente. Alguns experimentos revelaram que ambientes pintados com cores em tons de azul-verde tendem a gerar sensação de temperatura mais baixa do que a real, enquanto que tons de vermelho-laranja geram uma sensação contrária (ITTEN, 1970, p. 46).

\subsubsection{Conforto Olfativo}

O conforto referente ao olfato refere-se à percepção relacionada com a qualidade do ar dentro de um ambiente.

Diversos tipos de aromas podem provocar dor de cabeça e alergias, outros, como fumaça e gases expelidos por chaminés, podem indicar a presença de substâncias nocivas à saúde.

Pode-se pensar, então, que a ausência de todos os odores seja ideal, mas o que dizer, por exemplo, do cheiro que emana da flora ou do mar? Boa porcentagem das pessoas recuperam suas energias (físicas e mentais) quando entram em contato com esses odores. Outro elemento que se pode apontar é a identificação de determinado aroma com marcas de produtos específicos. A empresa Starbucks, rede mundial de café, por exemplo, investiu em seus equipamentos para prolongar o período de duração do aroma do seu produto (JARGON, 2009, p. 22). Os perfumes também podem direcionar respostas emocionais. O uso estratégico de aromas dentro de um espaço pode induzir os indivíduos a determinados comportamentos e estados emocionais, criando-se sensação de conforto, mesmo que ela não seja consciente. Alguns hospitais, em determinados espaços, empregam o recurso aromático para aliviar o estresse do paciente.

Muitas doenças e mal-estares são provenientes da Síndrome do Edifício Doente (SED), termo usado para as condições que ocorrem quando os seus ocupantes passam muito tempo em um ambiente que está carregado de contaminantes, tais como gases e vapores, aerossóis, odores, vírus, bactérias, esporos e fungos. Se a renovação do ar do edifício for baixa, a situação de mal-estar é agravada. 
Para se reduzir a má qualidade do ar deve-se fazer periodicamente a troca de filtros de ar e vedações adequadas para impedir a entrada de ar ou gases não filtrados.

A qualidade do ar de um ambiente fechado é medida por dois fatores principais: pela sensação de conforto proveniente do ar e pela ausência de efeitos nocivos para a saúde dos seus habitantes, tanto no aspecto psicológico quanto no aspecto físico (STEIN, et al., 2010, p. 116-125).

\subsubsection{Conforto Acústico}

Pode-se dizer que o conforto acústico implica em duas dimensões: o psicológico e o físico. O primeiro refere-se à satisfação proveniente dos sons recebidos. O segundo está relacionado às características físicas do som, que podem afetar negativamente a audição e o corpo.

O som resulta de um movimento oscilatório de um objeto e necessita de um meio elástico para se propagar (gás, líquido e sólido) e de um receptor para o interpretar.

Para a determinação do conforto/desconforto acústico, os parâmetros físicos importantes são o nível acústico e o espectro sonoro (TILLER, 2010). O principal órgão receptor de ondas sonoras é o ouvido e o meio condutor mais comum é o ar, sendo que a velocidade do som no ar seco e à $20^{\circ} \mathrm{C}$ é $344 \mathrm{~m} / \mathrm{s}$ (HENRIQUE, 2009, p. 208). Não só o ouvido capta essas vibrações, mas todos os órgãos humanos, os quais são afetados, distintamente, em determinadas faixas de frequência e podem causar sensação de desconforto. Dependendo do nível sonoro, frequências de $50-100 \mathrm{~Hz}$ e acima de $150 \mathrm{~dB}$ provocam náuseas, enjoos, afetam o abdômen e os pulmões; com 7 $\mathrm{kHz}$ e acima de $165 \mathrm{~dB}$ há aquecimento dos dedos; sons de altas frequências (acima de $10 \mathrm{kHz}$ ) e ultrassons (acima de $20 \mathrm{kHz}$ ), ambos acima de $140 \mathrm{~dB}$, há aquecimento das vias respiratórias e dos dedos; infrassons de $7 \mathrm{~Hz}$ afetam o cérebro. Ressalta-se que a frequência de $7 \mathrm{~Hz}$ é, considerada a frequência de ressonância das vísceras, e a exposição do corpo a essa frequência, pode provocar rupturas e levar à morte. A faixa de frequência de $30 \mathrm{a} 60 \mathrm{~Hz}$ afeta o globo ocular (DAVIES, 1999). 


\subsubsection{Parâmetros do ouvido humano, Intensidade sonora e Ruído}

O ser humano pode perceber sons na faixa de frequência de 20 a $20 \mathrm{kHz}$ (GRONDZIK, 2010, p. 741).

A Figura 2.5 ilustra a sensibilidade do sistema auditivo entre $20 \mathrm{~Hz}$ e 20khz, o limiar da dor e o limite de desconforto. A região de desconforto e de dor representam os limites superiores do nível sonoro que o ser humano pode tolerar. O desconforto ocorre a partir de $110 \mathrm{~dB}$ e a dor surge com $130 \mathrm{~dB}$, sendo que a sensação de desconforto e de dor não se altera em função da frequência do som (QUEHL, 2001, p. 27).

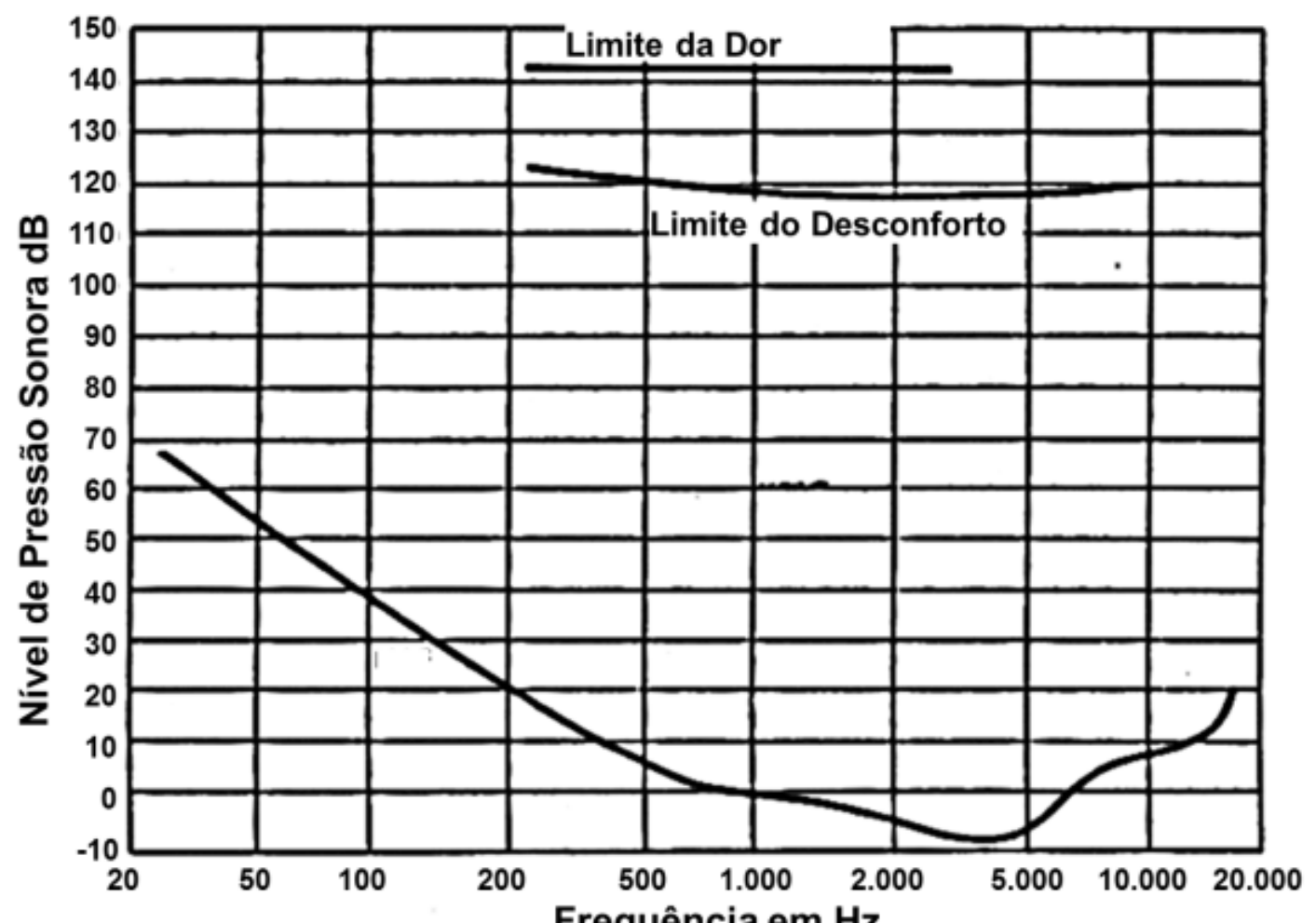

Figura 2.5 Limites de audição (MAF = Minimal Audible Field), desconforto e dor em dBs (adaptado de Slater, 1985).

\subsubsection{Intensidade sonora}

A percepção da intensidade sonora depende da pressão e da frequência sonora. $O$ sistema auditivo humano responde de maneira não linear com a variação da frequência sonora. A Figura 2.6 apresenta curvas de resposta entre potência sonora em $\mathrm{dB}$ e frequências em $\mathrm{Hz}$, com níveis de fones (unidade de medição de impressão de volume sonoro) constantes. Para a impressão sonora de $60 \mathrm{~dB}$, percebem-se 30 fones na frequência de $50 \mathrm{~Hz}, 50$ fones à $100 \mathrm{~Hz}$ e 68 fones a $1 \mathrm{kHz}$ (STEIN, et al., 
2010, 745-619) (ver Figura 08). Pode-se observar que o ouvido humano é mais sensível na faixa de frequência produzida pela voz humana do que outras faixas. $\mathrm{Na}$ faixa da fala humana há pouca necessidade de aumentar a potência sonora para manter o conforto acústico, mas é necessário eliminar fontes sonoras nessa mesma faixa de frequência a fim de que não ocorra dificuldade de entendimento do que se fala por parte do ouvinte. Um exemplo do que está sendo dito é a tolerância a altos níveis sonoros de automóveis como ruído de fundo durante uma conversa e uma intolerância ou distração ocasionadas pelo som de vozes de outras pessoas próximas à conversa.

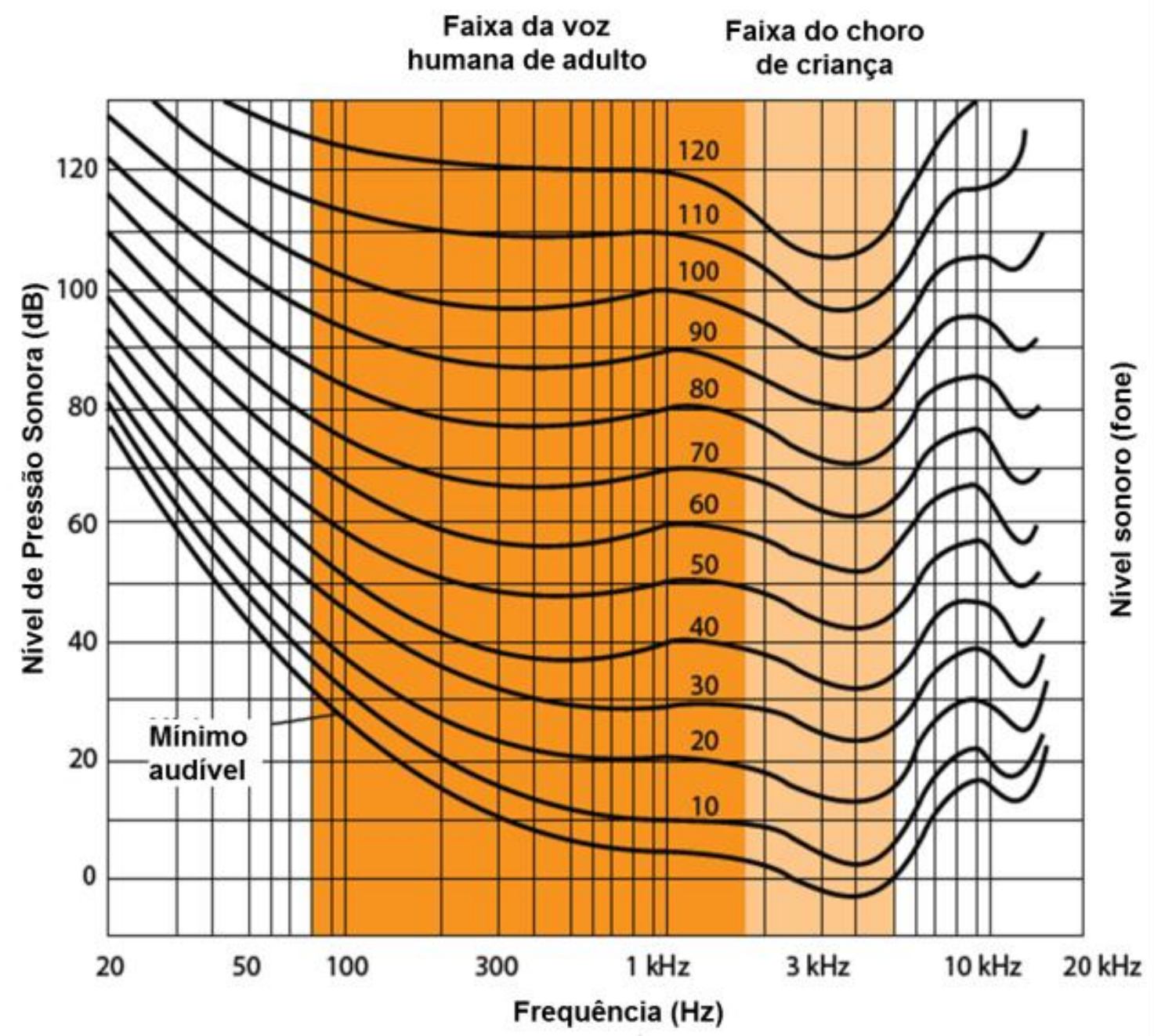

Figure 2.6: Fones e os efeitos no ouvido humano (STEIN, 2010, p. 746).

\subsubsection{Ruído}

Ruído é definido como qualquer som indesejável. O incômodo causado pelo ruído é proporcional a sua intensidade, aumenta em frequências altas, em ruídos 
intermitentes, com sons puros, com ruídos reverberantes, e é extremamente desconfortável quando uma informação estiver acompanhada de ruído.

\subsubsection{Conforto visual}

Uma iluminação correta auxilia na motivação de execução de tarefas, evita fadiga, mantem a saúde e protege de acidentes de trabalho.

Conforme DIN EN 12464-1 "Lighting of indoor work places" (Iluminação de ambientes de trabalho internos) (2003), os objetivos de uma iluminação adequada são estabelecidos para garantir o conforto visual, o desempenho do sistema visual e a segurança. O conceito de Conforto visual está relacionado a fatores visuais que propiciam às pessoas uma sensação de bem-estar no trabalho, enquanto o de desempenho visual descreve o objetivo de ser capaz de realizar tarefas visuais em períodos de tempo prolongados.

Com os avanços tecnológicos na área de iluminação, pode-se criar um ambiente de conforto, com possibilidade de adaptação para diferentes necessidades dos usuários.

A luz visível é a parte do espetro eletromagnético que permite aos seres humanos enxergarem. É uma faixa estreita do espectro eletromagnético total, conforme indicado na Figura 2.7. A Luz tem propriedades de partícula e propriedades de onda, e quando considerada como onda, tem uma frequência que está relacionada com a cor.

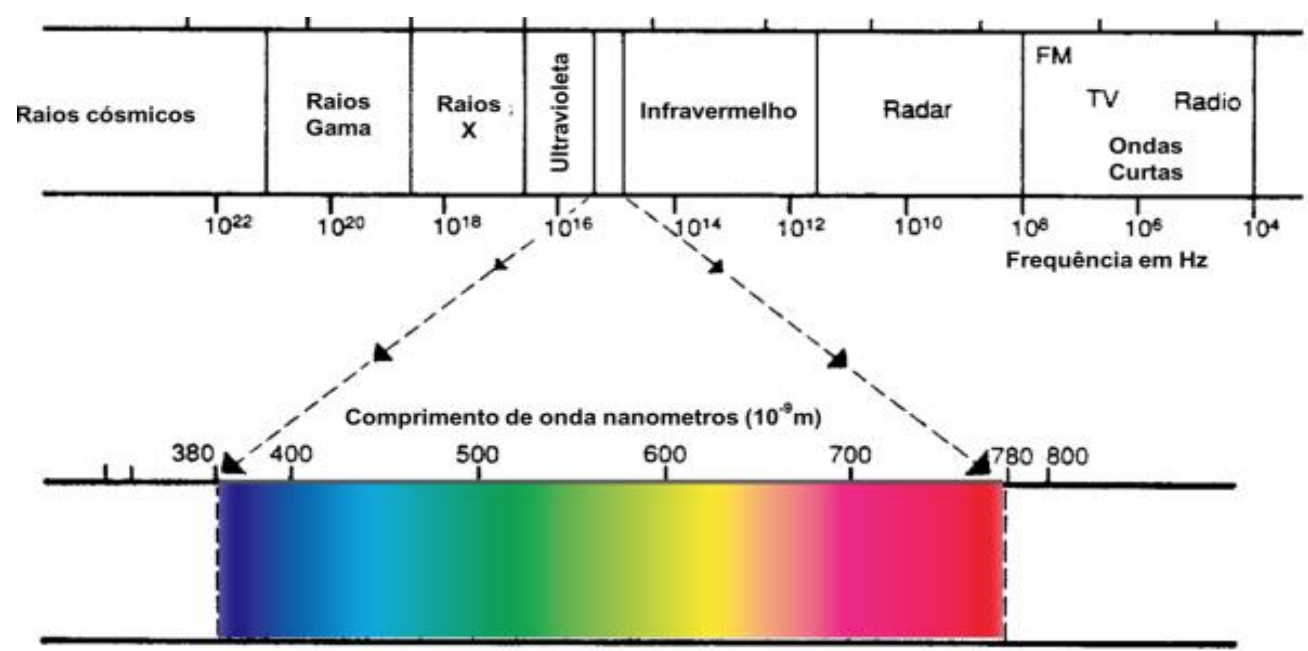

Figure 2.7 Espectro eletromagnético e luz visível (adaptação de STEIN, 2006, p. 460). 
Quando a luz atinge uma superfície, seu espetro ou parte dele pode ser transmitido, absorvido ou refletido. A cor de uma superfície representa a combinação das frequências do espectro visível refletido para o observador. Uma superfície branca reflete a maior parte do espectro incidente, enquanto que uma superfície preta absorve a maior parte do espectro incidente.

Para a análise do conforto visual empregam-se quatro tipos de características principais da luz: os níveis de luminosidade, o contraste, o brilho e a cor. O primeiro é utilizado para especificar a intensidade luminosa de determinadas áreas de um ambiente em função da tarefa que será executa naquele espaço. Dessa forma, salas cirúrgicas são muito mais iluminadas do que escritórios, que são muito mais iluminados quando comparados a salas de estar. O segundo tipo, o contraste, é considerado para aumentar a compreensão do objeto de interesse. Quanto maior o contraste, mais fácil a compreensão do objeto em observação. Por esse motivo, a maior parte das publicações usa texto em preto sobre papel branco ou combinações de cores contrastantes. O terceiro ponto, o brilho ou ofuscamento, é um aspecto indesejável, pois dificulta a visualização do objeto de atenção. O quarto, cor, é o que pode harmonizar um ambiente dando-lhe aspectos que propiciam conforto. Os projetos/instalações de iluminação devem levar em consideração essas características, além de outras, como distribuição da luz, para criarem ambientes confortáveis.

Existem referências para minimizar os problemas de conforto visual, com indicações de valores de luminosidade, contraste, distribuição das fontes luminosas, conforme a tarefa a ser executada:

- Taxas de contraste de 1:3 a 1:10 aumentam a concentração na tarefa executada e permitem a percepção de objetos adjacentes;

- O brilho pode ser reduzido com a utilização de múltiplas fontes de luz.

Esses itens representam apenas parte do que deve ser avaliado para se obter 0 conforto visual, mas nem sempre os valores de referência são empregados. Outros aspectos que devem ser abordados para tornar um ambiente mais confortável/ menos desconfortável são: evitar iluminação cintilante; evitar sombras; evitar reflexões especulares da luz incidente em superfícies espelhadas ou semifoscas; reduzir o ofuscamento - definido pelo (CIE) como a iluminação que causa desconforto sem 
necessariamente impedir a visualização da tarefa. $O$ ofuscamento pode ser produzido por excesso de luz ou pela heterogeneidade na iluminação do ambiente. Esses aspectos reduzem a visibilidade pela difusão da luz no olho (DERLOFSKE, J. V., BULLOUGH, J, i2004).

Várias fórmulas foram desenvolvidas e novas estarão por vir para tentar predizer e mensurar o desconforto causado pelo ofuscamento (CLEAR, 2012). Essa é uma das preocupações e desafios dos profissionais envolvidos em projetos de iluminação.

Quanto à mensuração do desconforto visual causado pelas cores, uma fórmula foi proposta por (SAGAWA et al., 2006).

$C($ escala de 100$)=w_{n} N+w_{r} R+w_{y} Y+w_{g} G+w_{b} B+$ const.

Onde a letra $\mathrm{N}$ significa o número de cores fundamentais em uma imagem e $\mathrm{R}, \mathrm{Y}, \mathrm{G}$, $B$ são componentes médios das cores contidas na imagem, $C$ é o índice de conforto em uma escala de 0 a 1 . A determinação do índice de conforto $C$ é feita por foto tirada do ambiente, convertida em imagem e então verificada as cores de cada pixel dessa imagem.

Segundo os autores, duas medidas colorimétricas são importantes para avaliar o desconforto visual: a saturação média das cores e o número de cores primárias contidas em uma cena.

O desconforto visual pode ser responsável por uma série de sintomas. Os mais comuns, são: olhos vermelhos; coceira; irritações; olhos lacrimejantes; dor de cabeça; enxaqueca; problemas gastrointestinais; dores associadas a uma má postura.

No presente trabalho o foco é o conforto/desconforto visual, considerando condições usuais da cabine da aeronave quanto aos aspectos de conforto térmico e acústico, conforme será detalhado no Capítulo 4. 


\section{Influência da Cor e da lluminação na percepção de Conforto e Desconforto}

Terminada a verificação acerca das definições de conforto e tipos de conforto, itens relevantes para este trabalho, neste capítulo são apresentadas as influências das cores e da iluminação de um ambiente no conforto ou desconforto dos seres humanos e como as cores são percebidas pelo processo cognitivo humano.

\subsection{A influência da cor}

As cores têm um papel muito importante no processo cognitivo do ser humano. Por meio delas pode-se criar nuances que aumentam a capacidade de percepção de detalhes, aumentam a quantidade de informação e facilitam a identificação de objetos.

O sistema visual humano é capaz de identificar infinitas cores, levando cientistas a pesquisarem o funcionamento do sistema visual de reconhecimento das cores. Thomas Young (1773-1829), cientista britânico, foi um dos que iniciaram a pesquisa da capacidade de visão das cores pelos humanos e identificou que bastavam apenas três cores primárias para criar infinitas cores, e imaginou que os elementos que compõem a retina deveriam ser de três tipos e, por meio de estudos e pesquisa conseguiu comprovar tal hipótese. Os cones possuem três tipos diferentes de pigmentos que absorvem preferencialmente uma das três cores básicas (vermelho, verde e azul). Os bastonetes possuem apenas um tipo de pigmento, que absorve mais a faixa do verde do que as faixas azul e vermelha. Como há cones e bastonetes que absorvem o verde, a percepção das cores pelo sistema visual torna-se mais sensível ao verde (LENT, 2010, p. 330). A sensibilidade visual maior ao verde talvez decorra dos primórdios da raça humana, quando o ser humano vivia muito mais tempo em contato com a vegetação. Talvez no futuro, com a redução das áreas verdes, o sistema visual sofra alterações e se adapte a um mundo com pouco verde, mudando as curvas de sensibilidade espectrais do olho humano.

Nesta pesquisa, ao se referir à cor e a sua reprodução, toma-se como base a fonte luminosa proveniente de um sistema composto por LEDs que emitem as cores primárias vermelho, verde e azul e LEDs que emitem luzes brancas com características de temperatura de cor quente e fria. Devido à faixa do espectro luminoso da luz emitida pelos LEDs ser muito estreita, o sistema apresenta 
limitações em termos de reprodução de cor. Esse sistema não permite que todas as cores perceptíveis sejam reproduzidas, fato que reduz a quantidade de cores possíveis de serem projetadas para tornar um ambiente agradável.

Ao se tratar de parâmetros de visão e percepção, os aspectos de cor na iluminação de objetos e ambiente, são de extrema importância, pois é parte integrante da determinação do conforto visual.

Como mencionado por Nishitani (2006), após o passageiro entrar no trem, ele não tem muito que fazer. A menos que durma, leia, use o computador, o indivíduo passará a olhar os objetos do interior da cabine. Esse fato indica a importância que tem o interior do trem ou de outro ambiente, que, intencionalmente ou não, passará a ser observado pelas pessoas que nele estejam. O interior da cabine é composto, entre outros elementos, por grandes superfícies coloridas (paredes, teto, chão, assentos) as quais dependem da luz incidente para apresentarem efeitos visuais predeterminados ou não. O conjunto de componentes e características dos objetos do interior da cabine exerce grande influência psicológica no desconforto dos passageiros.

\subsubsection{Conceitos básicos da Cor e sua percepção}

Existem basicamente dois processos para a obtenção de cores: o processo aditivo e o processo subtrativo. O processo aditivo está relacionado à caracterização da luz emitida e o processo subtrativo à luz refletida pelo objeto

No processo aditivo - RGB (Red, Green, Blue) - a cor da luz projetada é o resultado da adição de diferentes comprimentos de ondas. Nesse sistema as cores primárias empregadas são vermelho, verde e azul. O processo RGB é utilizado em aparelhos eletrônicos como câmeras digitais, projetores, monitores, Datashow.

No processo subtrativo - CMYK (Cyan, Magenta, Yellow e Black) - os pigmentos tem a propriedade de absorver certos comprimentos de ondas e refletir outros. Nesse sistema as cores primárias empregadas são ciano, magenta, amarelo e preto. 0 processo CMYK é utilizado frequentemente em impressões. O processo subtrativo sofre mais influência da luz ambiente do que o processo RGB. 
Existem diversos tipos de ondas no espectro eletromagnético do universo, "ondas de rádio, infravermelhas, visíveis, ultravioleta, gama e cósmicas" (FARINA; PEREZ e BASTOS, 2006). Nesse espectro de ondas, existem dez milhões de cores aproximadamente. As ondas e os raios visíveis podem ser medidos pela unidade nanômetro $(\mathrm{nm})$. O comprimento de onda da luz é muito pequeno - entre 400 e 780 $\mathrm{nm}$ (manômetro). A faixa de comprimento de onda entre 400 e $780 \mathrm{~nm}$ contém as ondas que estimulam a retina humana, que tem como resultado a sensação luminosa - luz - responsável pelo fenômeno da cor. Acima de 780nm, encontram-se as ondas de infravermelho e abaixo de $400 \mathrm{~nm}$ estão as ultravioletas, raios que a visão humana não consegue perceber (FARINA; PEREZ e BASTOS, 2006, e GRANDJEAN, 1998). A Tabela 3.1 apresenta as cores e sua faixa de comprimento de onda.

Tabela 3.1 As cores da luz têm comprimentos de ondas específicos (FARINA; PEREZ e BAS TOS (2006):

COR Faixa de Comprimento de Onda (nm)

Roxo ou Violeta $400-450$

Azul $450-500$

Verde $500-570$

Amarelo $570-590$

Laranja $590-627$

Vermelho

$627-780$

O olho é estimulado por diferentes comprimentos de onda e a superfície dos objetos, por meio de seleção, absorve ou reflete essas ondas. A percepção da cor branca ocorre quando um objeto reflete todas as ondas que o atingem. Nesse caso, os comprimentos de onda chegam simultaneamente ao olho, que percebe a superfície como branca. O oposto acontece quando a superfície de um objeto absorve determinados comprimentos de onda e não as reflete. O resultado é a percepção de um corpo como preto. Quando os comprimentos de onda que compõem a luz branca atingem uma superfície de um objeto, mas parte dessas ondas é absorvida e parte é refletida, há o fenômeno da cor. 
Em termos físicos, a luz é incolor. Somente adquire cor quando interage com algum objeto. Portanto, cor "não é uma matéria, nem uma luz, mas uma sensação" (FARINA; PEREZ; BASTOS, 2006, p.60). A cor, dessa maneira, só existe porque o indivíduo a percebe como cor por meio da luz e do objeto que a reflete.

A cor de um objeto é definida como a cor da luz refletida ou transmitida por um objeto quando ele for iluminado por uma fonte luminosa padrão, ou seja, quando dizemos que um material tem uma determinada cor também precisamos mencionar qual a fonte luminosa a que o objeto está sendo observado.

A percepção da cor resulta de uma complexa interação dos estímulos visuais recebidos pelo olho e da interpretação que o cérebro faz destes estímulos. Os raios luminosos que chegam até a retina são convertidos em sinais elétricos. Estes sinais elétricos são transmitidos, através do nervo ótico, para o cérebro que os interpreta, criando-se a percepção da cor.

O olho é o receptor, que capta a energia e o cérebro, o processador das informações recebidas, em que o cérebro compara, analisa, sintetiza, usa as emoções e intuições para decodificar os dados recebidos (FLOR; CARVALHO, 2012 p. 334). O processo de transformação dos estímulos recebidos em informações dotadas de sentido permite que o homem perceba as nuanças das cores e outras características do mundo externo, como intensidade da luz ambiente, localização espacial dos objetos de interesse, brilho, forma, posição, movimento, sombra ou reflexo.

Como a visão depende da luz, é a iluminação que propicia condições para que o homem possa exercer suas atividades de modo eficiente, seguro e confortável. $O$ processo de visão varia em função das condições de Luminância dos objetos e da iluminação do ambiente.

A intensidade luminosa além de seu valor objetivo, que é obtido por meio de equipamentos eletrônicos, também tem valor subjetivo que é o resultado das adaptações do sistema visual em função dos estímulos recebidos. Esses fatores são, além da energia luminosa, a capacidade de adaptação da retina, o nível de ruído interno criado pelo próprio sistema visual, a cor do que se observa e as condições de contorno a cena observada (LENT, 2010, p. 324). Tais adaptações fazem com que a 
luz de uma vela acesa à noite aparente ser mais intensa do que de dia, apesar de sua energia irradiada ser a mesma.

A análise dos processos de visão permitem entender o que ocorre nas diferentes situações de trabalho do ser humano. As diferentes tarefas executadas pelo homem, que dependem da visão, variam em função dos estímulos visuais absorvidos pelo sistema nervoso. Dessa maneira, o desempenho de determinada atividade terá maior ou menor eficiência, de acordo com a influência causada pelas condições de iluminação ambiental. Ao desenvolvermos tarefas que dependem da visão, estamos sujeitos a estímulos visuais que são absorvidos pelo sistema visual de forma que possamos executar tais tarefas com uma determinada eficiência.

\subsection{2 Índice de Reprodução de Cor}

Índice de Reprodução de Cor (IRC) é uma expressão utilizada para se referir ao efeito de uma fonte de luz sobre a aparência dos objetos em comparação com sua cor aparente sobre outras fontes de luz. É a qualidade de reprodução de cores sobre uma dada fonte luminosa. O grau de distorção da cor em comparação com uma fonte de luz padrão é classificado pelo índice de reprodução de cor, a escala desse índice é de 0-100, sendo que quanto maior for valor desse índice maior será a capacidade de reprodução de cor (IESNA, 2000).

\subsubsection{Mecanismo da percepção visual}

A retina possui mais de 100 milhões de células que recebem fótons provenientes do ambiente onde o ser humano se encontra, após terem transpassado a pupila, que é o diafragma do olho e o cristalino, que é uma lente convergente. Essas células estão divididas, basicamente, em bastonetes e cones. Os bastonetes se situam na periferia de cada olho e são responsáveis pela detecção da luz branca de baixa intensidade. Os cones estão localizados no centro do olho e são fundamentalmente de três tipos sensíveis à luz vermelha, azul e verde. Quando a luminosidade é baixa, os bastonetes têm maior atuação e obscurecem os cones, fazendo com que a percepção de forma se sobreponha à da cor. 
Após a sensibilização dos cones e bastonetes, a informação visual é transmitida ao tronco cerebral por meio dos nervos óticos devido a uma variação de potencial elétrico. Meyer (2002) menciona que o tronco cerebral é uma entrada de sensações que precede o córtex cerebral, o qual é responsável por decifrar as informações recebidas. Uma filtragem ocorre entre o tronco cerebral e o córtex, a qual seleciona parte das informações captadas pela retina segundo o contexto fisiológico, psicológico, cognitivo, ambiental e outros a que está sujeito o indivíduo. Ao sinal luminoso captado pela retina, são acrescentados dados mnemônicos. Simultaneamente são feitas comparações e são adicionadas outras informações sensoriais. Após o processamento das comparações, das classificações e das interpretações das sensações visuais chega-se finalmente, à percepção visual.

\subsubsection{Percepção visual colorida}

As variações de cores provocadas por mudança de luminosidade branca ou por pequenas mudanças da fonte luminosa são ajustadas pelo córtex de modo que não cause grandes impactos na percepção de uma cor. Essa adaptação do córtex à luz é o que permite o indivíduo perceber a cor de uma peça de vestuário, como sendo a mesma, seja sob uma luz de uma lâmpada de filamento ou sob a luz de uma vela. Segundo Meyer (2002), o cérebro, além de registrar passivamente as mudanças da natureza física, cria um universo colorido imóvel, ou pouco móvel, em razão da sensação recebida inicialmente.

Segundo Crick (1998) a cor de um objeto é definida em relação àquelas que estão ao seu redor, e um ajuste permanente mantém essa comparação constante: $O$ cérebro não se interessa tanto pela combinação da reflexão e da iluminação quanto pelas propriedades coloridas da superfície dos objetos. Ele tenta extrair essa informação comparando a resposta dos olhos em diferentes regiões do campo visual.

A região do cérebro responsável pela visão das cores negligencia variações de cores em função de mudanças de intensidade luminosa, e mantem a cor considerada principal imutável.

Vigouroux (1992) resume a percepção das cores da seguinte forma: 
A apreciação sutil das cores que exige, por exemplo, a observação de um quadro, implica um papel ativo do córtex, um ato de juízo e não de sensação. Com efeito, a visão cromática de uma composição mantemse a mesma, quaisquer que sejam as condições de iluminação. Conserva uma surpreendente constância, apesar de alterarem as características físicas da luz que é refletida. Este fenômeno pressupõe a capacidade do sistema nervoso para extrair de dados variáveis um modelo interno invariável que representa a cor captada. Implica a existência de neurônios, cuja atividade não depende dos comprimentos de onda recebidos pelo olho, mas de uma definição cromática determinada. De certa forma, o cérebro distribui a cada construção uma tonalidade colorida, deduzida não apenas a partir das sensações que lhe chegam e da luminosidade, mas também de um modelo de representação interna de cores (p. 159).

Outra caraterística da visão colorida é que ela desaparece quando dois ou três comprimentos de onda diferentes e que excitam os seus cones correspondentes, atingem a retina simultaneamente, em uma mesma região e com idênticas intensidades. Essa particularidade da visão justifica o fato da somatória das cores criarem uma sensação de cor diferente. Por exemplo, se olharmos três círculos adjacentes nas cores vermelho, azul e verde, os veremos como tal. Porém, se esses círculos forem sobrepostos, a cor resultante será a branca.

A visão de cores não é simplesmente uma percepção ordenada de fótons dispersos, que posteriormente são rearranjados. O sistema sensorial humano não é estável como um espectrofotômetro (aparelho utilizado para medição de cores, vide item 3.1.6.2), ele está envolto com memórias interpretações, focalizações visuais, comparações, e outros fatores. Para um mesmo observador, conforme ponto de fixação de seu olhar em um objeto, o equilíbrio das cores varia, ao passo que com um espectrofotômetro será sempre a média da luz que é recebida por este equipamento. O cérebro só percebe realmente o que procura sobre efeitos de estimulações sensoriais e de seu próprio pensamento.

\subsubsection{Significado das cores na literatura}

Os significados das cores são filtrados pela religião, pela sociedade, pelos mitos, pelas emoções, pela memória. Esses filtros fazem com que não ocorra uma sensação puramente física de uma difração de fótons. O ser humano não é uma máquina desprovida de emoções. O sistema cerebral faz uma série de associações 
com neurónios que contem informações memorizadas, de emoção, de percepção sensorial e de julgamentos, o que conduz a uma imagem perceptual impregnada de informações e de experiências passadas.

Para os cristãos, a cor azul-celeste remete à Virgem Maria, o branco é símbolo de pureza. O verde é a cor símbolo do islamismo, Khidr, o mensageiro divino no alcorão e mentor de Moisés sempre veste verde. Na Idade Média o ouro exaltou as áreas mais nobres da luz (MEYER, 2002).

Segundo Brusatin (1987) as cores exprimem as boas e as más reações: verde para a esperança, vermelho para a vingança e branco para a pureza; o amarelo é dominação e arrogância; o encarnado, os prazeres do amor. No século XIX, o vermelho era uma cor militar, tinha uma conotação revolucionária. No Oriente o significado das cores é diferente; o preto, por exemplo, indica sabedoria.

O violeta aparece no século II, como cor da separação e da viuvez; é uma cor de meio-luto, assim como o malva e o cinza. Após o Concílio de Nicéia, os católicos militantes faziam dela a cor do jejum.

Os objetos têm cores, formas e volumes constantes, porém a percepção que deles temos é função de como o cérebro humano se desenvolveu, desde o início de suas atividades.

Farina; Perez e Bastos (2006), assim como outros autores veem a cor como uma "linguagem individual", que se modifica de acordo com o meio em que vive o indivíduo, sua educação, temperamento, idade, sexo e sua história de vida. O gosto por determinada cor dependerá das características físicas da cor e das condições psicológicos do observador, bem como, da religião, da cultura, do gênero, da raça dentre outros aspectos.

A influência da cor sobre as sensações e as emoções é fato reconhecido por pesquisadores de diferentes áreas de estudo. Por meio delas a percepção de volume, de espaço, assim como a distância que se tem de objetos e ambientes pode sofrer alteração. A cor é utilizada, ainda, em experiências de laboratório. De acordo com Farina; Perez e Bastos (2006), a luz verde, por exemplo, pode contribuir para a morte de larvas de moscas e besouros, enquanto a cor anilada tem efeito analgésico e a 
vermelha estimula funções orgânicas. Existem pesquisas que tem como objeto de estudo a relação entre cores e doenças - as experiências apontam o azul como benéfico em certas doenças "dos olhos, ouvidos, nariz e pulmões; o vermelho, para estômago, fígado e baço; o verde, para o sistema nervoso e aparelho digestivo" (2006, p. 18). Há investigações ainda a respeito da relação entre cor de alimentos e funções biológicas. $\mathrm{O}$ autor cita que estudos cromoterapeutas mostram que as cores amarela e café não são adequadas para o interior de avião, pois podem provocar enjoo.

No âmbito social, a cor está estreitamente ligada a aspectos afetivos da vida humana. A indústria publicitária estuda e se vale desses elementos para atingir o consumidor de maneira positiva.

De acordo com Farina; Perez e Bastos, (2006), a cor produz sensação de movimento. O amarelo se expande no espaço, o azul causa sensação de vazio, distância, profundidade. A percepção do espaço pode variar de acordo com a cor utilizada e com a maneira que é harmonizada com outras cores. Os decoradores amparam-se em dados perceptivos da cor para atingir seus objetivos

A Associação de Normas Técnicas (ABNT), conforme norma NBR 7195/1995, emprega a linguagem psicológica das cores para as normas de segurança do trabalho (Idem, p. 88-89): o azul é utilizado em controles de equipamentos elétricos; a cor laranja está presente em partes perigosas de equipamentos; o vermelho é a cor usada nos equipamentos de proteção contra incêndio; o verde é a cor da caixa de socorros de urgência; o branco indica o sentido de circulação e o preto, coletores de resíduos. As cores são utilizadas nos códigos de trânsito: o vermelho significa perigo, o amarelo, atenção e o verde, segurança, passagem livre.

Os sinais visuais só têm funcionalidade se forem decodificados rapidamente pelo público a que se destinam. Para que isso aconteça há o estudo psíquico, social, cultural e fisiológico da influência da cor na percepção e reação do homem.

As pesquisas mostram que, pelo motivo do cristalino do olho humano se amarelar ao longo da idade, o homem, que na infância absorvia 10\% da luz azul, na idade avançada passa a absorver $57 \%$. Esse fenômeno leva a uma preferência pela cor 
azul, por parte de adultos e idosos, ao contrário de jovens que optam por cores fortes (FARINA; PEREZ E BASTOS, 2006).

Apesar de as investigações ainda estarem em andamento, há estudos a respeito da reação física diante da exposição das cores. Segundo Fère (1887), a luz colorida interfere na circulação sanguínea e na musculatura, intensificando ambas. Lüscher (1980) afirma que pessoas expostas ao vermelho por determinado tempo, têm sua pressão arterial elevada e seu ritmo cardíaco alterado, mas o oposto ocorre diante da cor azul.

Além das áreas citadas, constata-se o uso da cor na terapia, no trabalho do psicólogo por meio de trabalhos artísticos.

Outros fatores são importantes na percepção da cor. A posição de uma ou determinada cor em uma tela, por exemplo, também tem influência na percepção do indivíduo; na parte inferior de um quadro a cor parece mais escura do que na parte superior.

Grandjean (1998), afirma que as cores escuras são "abafantes, sufocantes e desestimulantes", ao passo que as cores claras parecem ser leves, amistosas e estimulantes.

Para Lacy (2007) as cores utilizadas nos ambientes podem afetar o comportamento e o estado emocional do homem, por vezes de maneira negativa. Para a autora, o estudo da psicologia das cores merece atenção, pois seu conhecimento pode auxiliar em muitos aspectos da vida moderna, entre eles, o estresse.

Os estudos a respeito do fenômeno e percepção das cores fornecem muitas informações a respeito do impacto emocional que podem estimular ou das sensações que podem surgir quando se está exposto a elas. No entanto, não se trata de fórmulas, mas de "dados científicos do emprego do movimento, da cor ou da luz", que será modificado ou sofrerá variações de indivíduo para indivíduo.

As cores têm dois polos de sensações - positivas e negativas, dependendo do contexto que é utilizada e por quem é utilizada. De acordo com Farina; Perez e Bastos (2006), "as cores constituem estímulos psicológicos para a sensibilidade 
humana" e, a partir da experiência que se tem com as cores ao longo da vida, as sensações com relação a ela serão positivas ou negativas.

Com relação aos efeitos psicológicos das cores, Grandjean (1998) sintetiza as ilusões das cores por distância, temperatura e disposição psíquica geral.

Como pode ser visto na Tabela 3.2, as cores que causam efeito de distância são o azul e o verde e as de proximidade, o vermelho e amarelo. As cores laranja, marrom e violeta, segundo Grandjean, provocam uma sensação de proximidade excessiva. Com relação à temperatura, o azul e violeta, provocam sensação de frio e a cor vermelha, de quente. Os efeitos das cores laranja e amarelo são de muito quente; marrom, de neutro e a cor verde, de frio a neutro. Voltando-se aos efeitos psicológicos das cores, de acordo com os estudos de Grandjean, o azul é capaz que transmitir tranquilidade e o verde, de muita tranquilidade. As cores laranja, amarela e marrom são estimulantes; a vermelha causa irritabilidade e a violeta, agressividade.

Tabela 3.2 Efeitos psicológicos das cores

\begin{tabular}{cccc}
\hline Cor & Efeito de distância & Efeito de temperatura & Disposição psíquica \\
\hline Azul & distante & frio & tranquilizante \\
\cline { 2 - 4 } Verde & distante & frio a neutro & muito tranquilizante \\
Vermelho & próximo & quente & muito irritante e não tranquilizante \\
\hline Laranja & muito próximo & muito quente & estimulante \\
\hline Amarelo & próximo & muito quente & estimulante \\
\hline Marrom & muito próximo & neutro & estimulante \\
\hline Violeta & muito próximo & frio & agressividade, não tranquilizante \\
\hline
\end{tabular}

Ao examinar documentos e textos a respeito da percepção da cor, das sensações e reações que surgem a partir da relação homem-cor, pode-se encontrar o seguinte:

\section{Preto}

No processo RGB, o preto é ausência de cor e no CMYK é composto do pigmento preto. 
Preto, do latim niger (negro), é ausência de luz ou ausência de cor. A cor preta associa-se a aspectos negativos e positivos.

Em Salazar e Chiarini, a cor preta está relacionada a elementos como masculino, pessimismo, tristeza, dor, bem como qualidades como distinção, nobreza ou elegância.

Em Farina; Perez e Bastos (2006), a cor preta pode associar-se a situações obscuras (funeral, noite, morte, sujeira, escuridão), ou ainda à miséria, pessimismo, negação, ausência, angústia, mas também a situações de sofisticação e requinte. O uso em excesso estimula a melancolia, depressão, confusão, medo. Quando combinada com outras cores, o preto pode expressar alegria.

A cor preta faz parte também da cultura Rock'n'roll e rock que se instalou como estilo de rebeldia e protesto, assim como as variações punk, hard rock, heavy metal e outros.

\section{Azul}

No processo RGB, a cor azul é formada pela sobreposição dos pigmentos ciano e magenta. No sistema CMYK, o azul é formado somente pelo pigmento azul.

Azul, de origem árabe e persa - lázúrd, lazaward (azul), é a cor do céu e do mar.

Lacy(2007) associa o azul à lealdade, integridade, respeito, responsabilidade e autoridade. É uma cor capaz de promover o relaxamento. Segundo a autora, alguns tons de azul ajudam a diminuir a violência. Essa cor é indicada para hospitais e clínicas, mas não em excesso, o que favorece a criação de um ambiente frio.

Para Salazar e Chiarini (2007), a cor azul está ligada à fala, é a cor da espiritualidade da intuição e das faculdades mentais. A cor azul acalma, estimula a harmonia, a interiorização e a paz, mas também a tristeza e a melancolia.

O azul escuro associa-se à sofisticação, sobriedade, acolhimento, inteligência, recolhimento, inteligência, serenidade, recolhimento, paz, confiança e densidade. Essa cor é muito empregada para representar a sensação de frio (FARINA; PEREZ E BASTOS, 2006). Produz diferentes emoções de acordo com a cor que é combinada e é considerada uma cor romântica, no entanto, em demasia, pode expressar certo tom 
de monotonia. Quando sombrio, o azul transmite a sensação de infinito. O azul claro provoca uma sensação de frescura e de higiene, combinado com o branco, pode levar vezes à introspecção (FARINA; PEREZ E BASTOS, 2006).

A cor azul ajuda a baixar a pressão arterial, reduz o stress e a ansiedade, favorece as atividades intelectuais e a meditação.

\section{Verde}

No processo RGB, o verde é composto somente pelo verde e no sistema CMYK é formado pelo ciano e amarelo.

Verde, do latim viridis, é a cor da natureza e está no centro do espectro.

Lacy (2007) apresenta a cor verde como sendo a cor do equilíbrio e da harmonia. Segundo a autora, o tom do verde tem a característica de se harmonizar com as outras cores do espectro e ajuda a reduzir a tensão e o stress. Auxilia ainda na redução da pressão arterial, do estímulo da autoestima, promove a sensação de liberdade e relaxamento. Em Salazar e Chiarini (2007), a cor verde estimula o metabolismo, atua na fidelidade, solidez, responsabilidade, sucesso profissional e é calmante. Salazar e Chiarini (2007) apontam a cor verde como estimulante do metabolismo e da glândula pituitária, favorece a dilatação dos capilares, a produção da sensação de calor e a reconstrução dos tecidos e músculos. Essas mesmas características aparecem no texto de Farina; Perez e Bastos (2006), que acrescenta o verde como calmante de dores nevrálgicas e benéfico em determinados casos de fadiga nervosa e insônia.

Lacy (2007) aponta os tons de verde escuro como responsáveis por proporcionar sensações de força e estabilidade e os tons claros pelas sensações de bem-estar. A autora acrescenta que as crianças, em geral, se identificam com os tons de verde claro, por estarem próximos à natureza, que, proporciona equilíbrio e bem estar. Os adultos, segundo a autora, se distanciaram da harmonia entre o homem e a natureza. 
Marrom

No sistema RGB, o marrom é uma variação do vermelho. No sistema CMYK, o marrom é formado pelo ciano, magenta, amarelo e preto.

Marrom, do francês - marrom (castanho) - é a cor da terra. Do período medieval ao atual, o marrom é associado a cores de roupas populares, a tecidos que não passaram pelo processo de tingimento. Também é a cor do outono, do recolhimento, e, portanto, é comum a associá-la com o conforto que se busca em climas frios.

De acordo com Lacy (2007) e Salazar e Chiarini (2007) a cor marrom está relacionada com permanência, solidez, segurança, estabilidade e organização. Para essas autoras, marrom é a cor da organização, constância e bom senso. Significa maturidade, consciência e responsabilidade. Está ainda associada ao conforto, à estabilidade, à resistência e simplicidade.

\section{Roxo}

No processo RGB, o roxo se constitui pelo vermelho e azul. No sistema CMYK o roxo é formado pelas cores ciano, magenta e preto.

Roxo, do latim russeus (Vermelho-carregado). Farina; Perez e Bastos (2006) aponta o roxo como possuidor de poder microbicida. Noite, aurora, sonho, fantasia, mistério, egoísmo, grandeza, misticismo, espiritualidade, calma, delicadeza são aspectos associados à cor roxa (FARINA; PEREZ E BASTOS, 2006).

\section{Cinza}

No sistema RGB, a cor cinza é formada pelas 3 cores primárias, vermelho, amarelo e azul. No sistema CMYK, a cor cinza é obtida pela variação da intensidade da cor preta.

Do latim cinicia (cinza), do alemão gris (gris, cinza), é a cor intermediária entre a luz e a sombra (FARINA; PEREZ E BASTOS, 2006).

A cor cinza combina facilmente com outras cores e, talvez por isso, represente a neutralidade. O cinza é associado ao medo e, por isso, deve ser utilizado com 
moderação (LACY, 2007). Quanto mais sombrio, mais expressa desânimo e monotonia.

Em Farina; Perez e Bastos (2006), essa cor aparece relacionada ao tédio, tristeza, velhice, desânimo, seriedade, sabedoria, pena, aborrecimento, carência, máquinas, cimento, mas pode representar estabilidade e sucesso.

\section{Púrpura}

No sistema RGB, a cor púrpura é constituída pelo vermelho e azul. No sistema CMYK, obtém-se essa cor com o magenta, o amarelo e o preto.

Do latim purpura, descoberta, segundo Heller (2004), em 1.500 AC, era uma cor produzida de maneira artesanal e que se mantinha viva por mais tempo do que as outras cores. A cor púrpura, no Império Romano era usada somente pelo imperador e sua família. Talvez esses motivos tenham contribuído para sua associação com eternidade e nobreza.

A cor púrpura é constituída por grande quantidade de vermelho, o que favorece a emotividade do indivíduo (FARINA; PEREZ E BASTOS (2006). Transmite calma, autocontrole e respeito e é muito utilizada em locais de meditação.

\section{Violeta}

No processo RGB, a cor violeta, origina-se pela sobreposição do vermelho e azul. No sistema CMYK, pelas cores ciano e magenta.

Segundo Farina; Perez e Bastos (2006), violeta é diminutivo do provençal antigo viula (viola).

Salazar e Chiarini (2007) definem o violeta como a cor da transmutação e da espiritualidade. A cor violeta, de acordo com as autoras, atua sobre o pâncreas e o metabolismo endócrino, na circulação arterial, purificação do sangue e também na produção de leucócitos.

Lacy (2007) aponta a cor violeta como estimulante da criatividade musical e artística. Associa essa cor à devoção, lealdade de causa, ideais nobres e sensação de 
grandiosidade. Junto ao amarelo favorece a introspecção. Ao lado do verde, estimula a ajuda ao próximo. O violeta com tons de verde claro estimula a afetuosidade, mas com verde escuro, dá força. De acordo com a autora o violeta com vermelho tem o poder de afetar as pessoas de maneira profunda.

A cor lilás - violeta claro - auxilia na meditação em processos depressivos e também no abandono de vícios (SALAZAR e CHIARINI, 2007).

\section{Dourado}

No sistema RGB, o dourado é obtido pelo vermelho e azul. No processo CMYK, o dourado é formado pelas cores magenta, amarelo e preto.

O dourado ou cor de ouro está simbolicamente associado ao ouro, à riqueza, a algo majestoso. Dourado simboliza vibração elevada, vigor, inteligência superior e nobreza. É a cor da opulência, da luz e da prosperidade. Traz charme e constrói confiança, dá poder, persuasão, energia e inteligência.

\section{Bege}

No processo RGB, obtém-se o bege com o vermelho, amarelo e azul. No processo CNYK, o dourado é formado pelo amarelo e preto.

O bege é uma cor que transmite calma e passividade. Está associada à melancolia e ao clássico. A cor bege é muito utilizada em ambientes, cortinas, tapetes, porque apesar de um tanto inerte, o bege promove a sensação de aconchego e conforto.

\section{Prateado}

No sistema RGB, o prateado é o resultado da sobreposição do vermelho, amarelo e azul. No sistema CMYK, essa cor é formada somente pelo pigmento preto.

O prateado ou cor prata é uma cor associada ao moderno, às novas tecnologias, à novidade, à inovação. Prateado atribui valores relacionados ao metal, como brilho, solidez e valor. Transmite estabilidade, sucesso, qualidade e distinção, principalmente 
quando associado ao preto. A cor prata em excesso promove a sensação de frieza e distância (FARINA; PEREZ E BASTOS, 2006).

\section{Vermelho}

No processo RGB, o vermelho é formado somente pela cor vermelha. No processo CMYK, o vermelho resulta dos pigmentos magenta e amarelo.

Do latim virmiculus (verme, inseto), de onde se estrai o escarlate ou carmim, do árabe qirmezi (vermelho vivo), é a cor do sangue, da paixão, da aproximação, do encontro, mas também da agressividade (FARINA; PEREZ E BASTOS, 2006).

De acordo com Lacy (2007) o vermelho favorece a pessoa a se sentir corajosa, poderosa e ousada. Sugere ainda diferentes atitudes como, sensibilização, ao cuidado pelas pessoas, mas também a insensibilidade, o egocentrismo, o controle, domínio sobre as pessoas. Os tons escuros de vermelho induzem à violência e emoções negativas. Segundo a autora, a cor vermelha, pode ainda estimular o apetite. $O$ excesso de vermelho favorece a perda de noção de tempo e ativa a violência interior das pessoas. Para Salazar e Chiarini (2007) está relacionada à beleza física e sensualidade. É também a cor da emoção, vitalidade e autoridade. Para as autoras a cor vermelha revitaliza o corpo, mas também estimula os nervos sensoriais e favorece a liberação de adrenalina, por isso deve ser usada com cuidado.

\section{Magenta}

No sistema RGB, chega-se a cor magenta pelas cores vermelho e azul. No processo CMYK, na cor magenta há somente pigmento magenta.

Magenta - é a cor púrpura, resultado da sobreposição do azul-violeta e o vermelho. É um "vermelho isento de amarelo e azul" (FARINA; PEREZ e BASTOS, 2006).

Vermelho-magenta - não se encontra no espectro solar e se compõe da "síntese aditiva do vermelho-alaranjado com o azul-violeta" (FARINA; PEREZ e BASTOS, 2006).

Essa cor pode encorajar as pessoas a tomarem iniciativas, mas também favorece o surgimento de sensações de tristeza e melancolia caso a pessoa conviva demais com 
o magenta. A cor magenta está associada a respeito, dignidade, devoção, piedade, sinceridade, espiritualidade, purificação e transformação.

\section{Laranja}

No sistema RGB, a cor laranja resulta da sobreposição do vermelho e verde. No sistema CMYK, a cor laranja é obtida pelos pigmentos magenta e amarelo.

De origem indiana - nareng, levada à Arábia - narang e, posteriormente à Europa, a cor laranja é símbolo de iluminação de perfeição (FARINA; PEREZ e BASTOS, 2006).

De acordo com Lacy (2007), a cor laranja estimula a conversa, a vitalidade, a criatividade e a afetividade. Tons claros da cor laranja promovem sensações de conforto, alegria e expressividade. Os tons escuros podem ter um efeito negativo e sedativo. Segundo Lacy (2007), os tons escuros de laranja têm potencial para criar uma atmosfera deprimente, e provocar sensação de desamparo e insegurança. Em Salazar e Chiarini (2007), a cor laranja é apontada como capaz de desenvolver a força mental, a criatividade, as atividades artísticas, desportivas e intelectuais. Pode aumentar a vitalidade, alegria e o desejo por vencer e viver. $\mathrm{O}$ tom laranja estimula 0 bem estar.

O laranja estimula a comunicação, otimismo, generosidade, entusiasmo e aumenta o apetite. Ideal para salas de estudo/reunião e outros locais onde as pessoas se encontram para conversar.

\section{Rosa}

No sistema RGB, o rosa resulta do vermelho, verde e azul. No processo CMYK, na cor rosa só há pigmento magenta.

A cor rosa é o vermelho suavizado com o branco. Salazar e Chiarini (2007) classificam a cor rosa como sendo a mais sutil da paleta. Está relacionada ao amor incondicional e ao afeto. Favorece o surgimento de amizades, a manutenção do amor, a beleza e evita a depressão. 
Lacy (2007) associa a cor rosa à beleza, carinho, fragilidade e delicadeza. Segundo a autora, os tons de rosa claros podem ser relaxantes, estimulantes de cansaço; os tons escuros têm um efeito positivo, podem tornar as pessoas ativas.

\section{Amarelo}

No sistema RGB, o amarelo é obtido pelas cores vermelho e verde. No sistema CMYKO só há pigmento amarelo.

É a cor do sol e frequentemente associada a deuses, por estar próximo ao dourado. Do latim amaryllis, é a cor da luz que irradia em todas as direções (FARINA; PEREZ e BASTOS, 2006). Segundo os autores, o amarelo é estimulante e pode provocar irritação.

Salazar e Chiarini (2007) apontam o amarelo como a cor que age sobre a memória, a rapidez mental e o raciocínio. Segundo as autoras essa cor auxilia a vencer a timidez, favorece a comunicação, a alegria e também a criação.

A cor amarela, para Lacy (2007), é capaz de ativar a mente e estimular o pensamento para o desenvolvimento de ideias novas. Estimula o estado de consciência e alerta das pessoas e auxilia aqueles que apresentam dificuldade de aprendizagem, mas também alimenta o ego. $O$ amarelo age sobre cérebro, mas também pode favorecer a perda do senso de limite. $O$ tom de amarelo escuro tem um efeito negativo, cria pessimismo e negatividade, pode causar indisposição. Os tons claros do amarelo criam sensação de espaço. Está associada ao verão e ao calor, por isso é recomendada para ambientes frios.

\section{Turquesa}

No sistema RGB, Turquesa é o resultado das cores vermelho, verde e azul. No sistema CMYK, a cor turquesa é obtida pelos pigmentos ciano, amarelo e preto.

Lacy (2007) define a cor turquesa como extremamente relaxante e repousante, elemento que auxilia a reduzir o estresse. Na medicina holística tem efeito calmante, principalmente em casos de pânico. 


\section{Branco}

No sistema RGB, o branco é a sobreposição de todas as cores - vermelho, verde azul. No processo CMYK, o branco é a ausência de pigmento.

Do alemão blank (brilhante) e está associada à luz. O branco é a presença de todos os comprimentos de ondas visíveis. Para a civilização ocidental o branco é associado à vida e ao bem, mas para a cultura oriental é símbolo de morte, de fim, de nada (FARINA; PEREZ e BASTOS, 2006).

O branco tem a característica de realçar todas as cores (LACY, 2007) e de criar "uma impressão de vazio e de infinito" (SALAZAR e CHIARINI, 2007, p. 50).

A cor branca está associada à limpeza, liberdade, castidade e também criatividade e à paz. Farina; Perez e Bastos (2006). apontam o branco como a cor do vazio interior, da carência afetiva e da solidão e por esse motivo deve ser evitada a exposição prolongada em ambientes totalmente brancos. De acordo com a Organização Mundial da Saúde, é recomendado que as paredes de hospitais e ambulatórios, assim como os quartos, não devam ser unicamente de cor branca .

O significado das cores também, como já mencionado, depende, dentre outros fatores, de religião, cultura e etnia, conforme pode ser verificado no anexo 1 deste trabalho. Os dados apresentados neste item revelam as mudanças de significados que as cores adquirem nos diferentes contextos em que é empregada.

\subsubsection{Mensuração da cor}

A verificação das cores dos objetos pode ser feita em cabines especiais, com fontes de luz determinadas. Nesta verificação compara-se a cor do objeto com a cor padrão de referência. Esse método traz problemas de objetividade e reprodutibilidade, uma vez que é uma verificação subjetiva. Para se determinar as propriedades da luz e da cor de maneira objetiva, empregam-se equipamentos denominados espectrofotômetros e colorímetros. Com eles podem-se quantificar as características fotométricas do que se observa, e, deste modo, arquivar as informações de maneira digital. 
A classificação das cores é expressa em termos de Matiz (Hue), Brilho ou Valor (Value) e Saturação ou Intensidade ou Croma (Saturation ou Chroma). Com a criação de escalas para esses três fatores, pode-se medir a cor numericamente.

Matiz, Figura 3.1, é o estado puro da cor, sem branco e sem preto. É definida pelo comprimento de onda predominante. Com a mistura das cores primárias puras (verde, azul e vermelha) pode-se construir um círculo cromático com infindáveis matizes de cores, dependendo das proporções das cores primárias.

Brilho, Figura 3.1, é um termo empregado para definir o grau de claridade ou obscuridade de uma cor, ou seja, representa quão claro ou escuro está uma cor em relação a sua cor padrão.

Saturação, Figura 3.1, representa a pureza ou intensidade de uma cor, é definida pela predominância do componente matiz. Está relacionada com a largura da banda espectral que se observa.
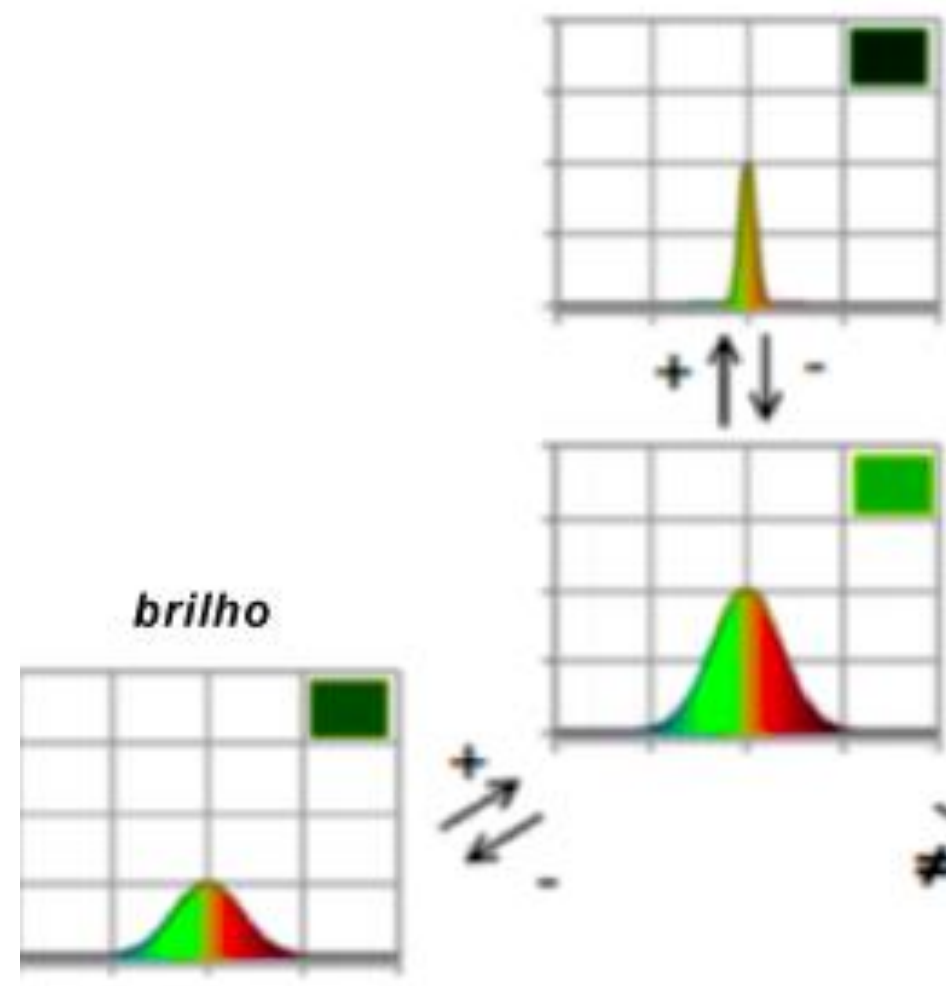

saturação
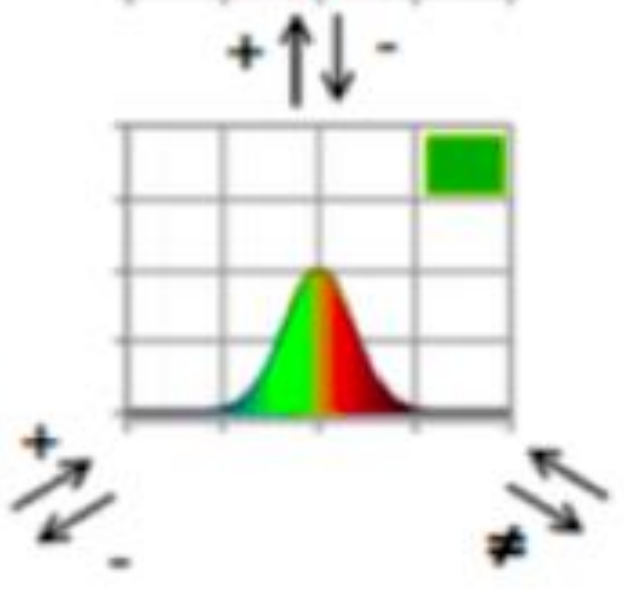

matiz (hue)

Figura 3.1 característica de espectros luminosos http://www.tecgraf.puc-rio.br/ mgattass/cg/pdf/02 Cor.pdf 


\subsubsection{Colorímetro}

Os colorímetros, Figura 3,2 possuem sensores que simulam o modo como o olho humano "vê" a cor, quantificando as diferenças de cor entre uma amostra e um padrão. Para que haja uma uniformidade nas medições deve-se empregar uma mesma fonte luminosa, não importando as condições de iluminação do ambiente.

O colorímetro possui uma fonte de luz interna a qual incide no objeto e é refletida para três sensores, que filtram a luz nos comprimentos de onda vermelho, verde e azul, tentando se assemelhar ao processo de captação das cores pelo sistema visual humano. Estes três sensores fornecem a resposta $X Y Z$ da cor.

\subsubsection{Espectrofotômetro}

O espectrofotômetro, Figura 3.2, também possui uma fonte de luz interna que incide no objeto e é refletida para um sistema de difração, que subdivide a luz em vários comprimentos de onda. Essa luz é então captada por uma matriz de diodos que mede a intensidade de luz recebida em cada sensor/diodo. Com a informação do espectro da luz emitida e da luz detectada pelos sensores, pode-se criar a curva espectral da cor medida. A partir desta informação, faz-se a integração da curva espectral de acordo com os filtros vermelho, verde e azul que a visão humana possui, fornecendose também os valores $X Y Z$ da cor.

Atenta-se para o fato de que se podem ter diferentes curvas espectrais que resultam em mesmos valores $X Y Z$, ou seja, com o espectrofotômetro obtém-se uma informação mais detalhada e caracterizada das propriedades físicas da cor do objeto do que o colorímetro. 


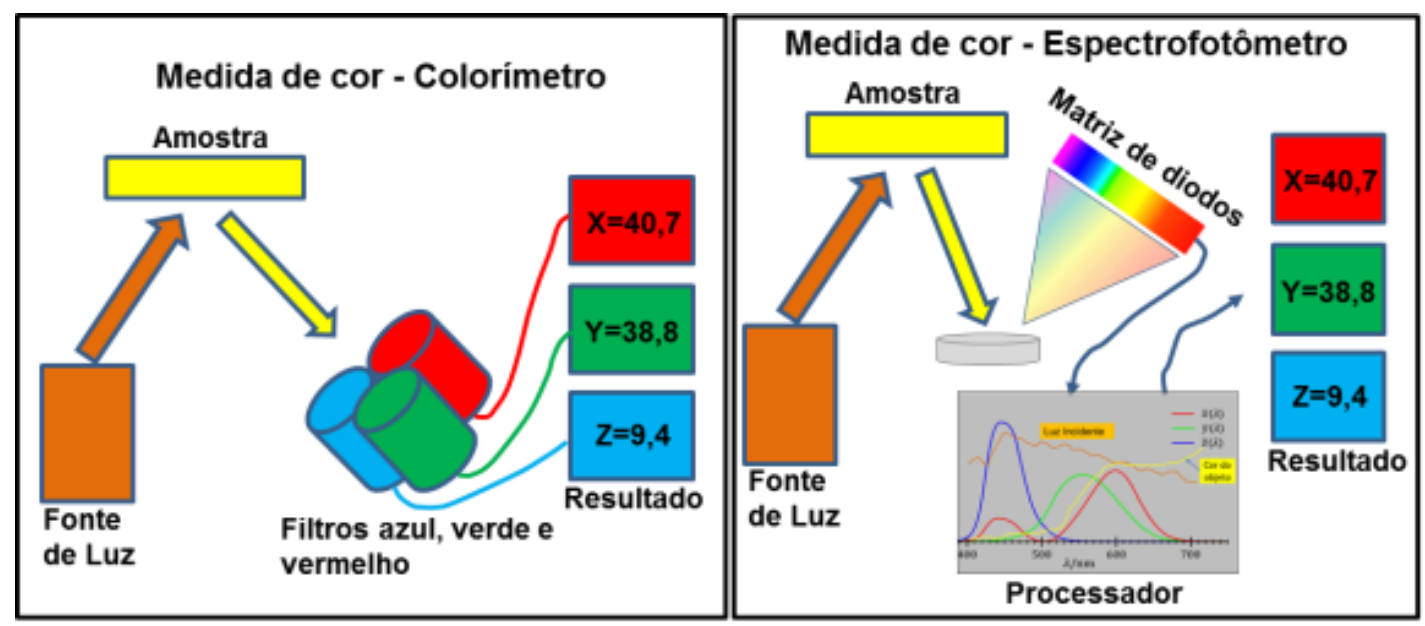

Figura 3.2 Esquema básico do funcionamento do colorímetro e do espectrofotômetro

A partir dos valores encontrados de XYZ podem-se calcular os valores colorimétricos nos diversos sistemas de espaço de cor, tais como, $x y Z, L^{*} a^{*} b^{*}, L^{*} u^{*} v^{*}, R G B, C M Y K$, HSV, entre outros. Estes espaços de cores são regulamentados pela comissão Internacional de lluminação CIE (Commission internationale de l'éclairage), sediada na Europa.

\subsubsection{Espectrorradiômetro}

Para a medição da cor da luz proveniente de uma fonte luminosa ou da cor de um objeto em função da incidência de uma luz qualquer, emprega-se o espectrorradiômetro, cujo princípio de funcionamento é semelhante ao do espectrofotômetro com a diferença de que não utiliza uma fonte de luz padrão própria. As respostas que este equipamento pode fornecer são curvas espectrais da luz captada pelo equipamento, temperaturas de cor e Luminâncias.

\subsection{Influência da lluminação na sensação de conforto}

Passa-se agora a apresentar algumas características dos efeitos da luz quanto ao conforto e o modo como a luz é percebida. 


\subsubsection{Condições de lluminação que podem causar desconforto}

Algumas condições de iluminação, descritas abaixo, podem causar desconforto, principalmente pela não homogeneidade da iluminação ou pela intensidade da luz.

Tremulação: sucede quando a iluminação não é constante.

Ofuscamento: ocorre de duas maneiras: muita luz ou quando a variação da Luminância do ambiente é muito grande. Conforme Derlofske e Bullough (2004), a redução da visibilidade pode ser atribuída pela difusão na luz no olho, a qual é dependente do ângulo de incidência da luz no olho.

Sombras: ocorre quando a luz de uma particular direção é interceptada por um objeto opaco.

Reflexões especulares ofuscantes (veiling): são reflexões luminosas das superfícies espelhadas ou semifosco que fisicamente mudam o contraste da tarefa visual e, portanto o estímulo presente no sistema visual.

\subsubsection{Percepção de lluminação}

O campo de visão do olho humano não é simétrico e é limitado. Para se detectar uma imagem pelo sistema visual, ela deve ser focada na retina. Os músculos responsáveis pelos movimentos do globo ocular fazem com que os dois olhos focalizem o mesmo ponto de atenção.

Como os olhos têm seus próprios movimentos e a cabeça também se move, a imagem retinal dos objetos se move na retina e muda sua forma e tamanho de acordo com as leis da física ótica. Além do mais, durante o dia as emissões espectrais mudam conforme o sol se "movimenta" no céu e conforme as condições climáticas. Apesar dessas variações, nossa percepção da realidade muda pouco. Essa invariância da percepção se denomina de constância perceptual (IESNA, 2000). 


\subsubsection{As constâncias perceptivas}

Existem quatro atributos fundamentais de um objeto que são constantes sobre várias condições de iluminação: luminosidade, cor, tamanho e forma.

1. Luminosidade: é o atributo relacionado com a quantidade física de refletância.

2. Cor: fisicamente, o estímulo que a superfície apresenta ao sistema visual depende do espectro do iluminante. Contudo, uma grande variação no conteúdo espectral de um iluminante pode ser feito sem alterar a percepção da cor do objeto.

3. Tamanho: conforme o objeto se distancia, sua imagem retinal diminui, mas o objeto em si não é visto como sendo menor.

4. Forma: conforme o objeto muda, sua orientação no espaço, sua imagem retinal também muda. Contudo em diversas condições de iluminação é possível distinguir sua orientação espacial, de forma que um disco sempre aparentará ser circular mesmo quando sua imagem for elíptica. (IESNA, 2000).

\subsubsection{Modos de Aparência}

Os objetos podem ter cinco atributos diferentes, dependendo da sua natureza e da maneira como são iluminados:

1. Brilho: um atributo baseado no julgamento do objeto emitir mais ou menos luz.

2. Luminosidade: um atributo baseado no julgamento do objeto refletir ou transmitir uma maior ou menor quantidade de luz.

3. Matiz: um atributo baseado na classificação de sua cor ou falta de cor.

4. Saturação: um atributo baseado em que uma cor é diferente mudando-se o brilho e a luminosidade. 
5. Transparência: um atributo baseado em que as cores podem ser vistas atrás ou dentro de um objeto

6. Difusividade: um atributo baseado em que a superfície é diferente em função da rugosidade, com uma mesma luminosidade, matiz, saturação e transparência.

Todos estes atributos devem ser considerados quando se faz um projeto arquitetônico de um ambiente. Dependendo da escolha do tipo de acabamento de cada objeto, pode-se criar um ambiente com mais conforto visual.

O estudo dos conceitos apresentados no decorrer deste capítulo fundamentaram as estratégias criadas para o desenvolvimento desta pesquisa. No próximo capítulo farse-á referência aos procedimentos empregados na investigação. 


\section{MÉTODO DE TRABALHO}

Depois de se verificar a influência da cor na sensação de conforto e desconforto, bem como conceitos relacionados à cor, percepção visual e iluminação, apresentam-se neste capítulo as condições em que os experimentos foram realizados, bem como os procedimentos e estratégias empregadas no desenvolvido deste estudo.

\subsection{Delineamento Experimental}

A EMBRAER (Empresa Brasileira) em parceria com, a USP (Universidade de São Paulo), UFSCar (Universidade Federal de São Carlos), UFSC (Universidade Federal de Santa Catarina) e com apoio da FAPESP idealizou um projeto de aperfeiçoamento de Conforto e Design de uma cabine de aeronave. O objetivo foi avaliar a resposta do ser humano ao conforto, em função da influência da temperatura, pressão, umidade, iluminação, ruído e vibração, além de aspectos ergonômicos. Os ensaios foram divididos em duas fases, a de ensaios dedicados e a de ensaios integrados. Nos primeiros, avaliaram-se individualmente as influências das condições de conforto para que se pudessem definir quais condições seriam aplicadas na fase de ensaios integrados. Na fase de ensaios integrados fizeram-se combinações de todas as condições definidas nos ensaios dedicados, iluminação com temperatura, com umidade, com ruído, com pressão, com ergonomia e com vibração.

Cada projeto dedicado estabeleceu diferentes condições a serem utilizadas nos ensaios integrados.

No aspecto de iluminação, a pesquisa foi destinada a analisar a influência da cor da iluminação nas atividades dos passageiros e observar se haveria correlação na percepção de conforto com a as outras variáveis (dos projetos dedicados) em estudo.

Os estudos práticos foram feitos em uma cabine de aeronave, mockup ${ }^{2}$, que simula um ambiente semelhante ao interior de jatos comerciais 170 e 190 da EMBRAER, com capacidade para 30 passageiros.

\footnotetext{
${ }^{2}$ Mockup: modelo em tamanho natural de um produto/dispositivo usado para simulações e avaliações de determinados objetivos, antes da produção em série desse item.
} 
Para a determinação do conforto/desconforto visual, foi selecionado um grupo de avaliadores, constituído por pessoas com características representativas de diferentes universos etários. A função dos avaliadores foi a de verificar a influência das características visuais do ambiente na sensação do conforto/desconforto em diferentes condições de voo.

O tempo de exposição dos avaliadores aos diferentes ambientes foi predeterminado e condizente com a duração de um voo de curta distância, mas suficientemente longo para que se instalasse a ambientação necessária às condições específicas de determinada cor de iluminação. O tempo e o perfil do voo estão descritos no capítulo 5.

A partir dessas definições, os avaliadores foram submetidos ao experimento. As informações coletadas subsidiaram a análise dos dados, e possibilitaram definir tendências de desconforto/conforto em função das características da luz e dos objetos.

Os procedimentos adotados foram:

a) O ambiente de ensaio;

b) Determinação dos instrumentos de coleta de dados;

c) Determinação dos pares bipolares;

d) Definição das cores de iluminação;

e) Seleção dos avaliadores;

f) Protocolo dos ensaios;

g) Preparação para a análise dos resultados.

\subsection{O Ambiente de Ensaio}

Os experimentos foram realizados em um laboratório que simulou um ambiente de aeroporto, que consistiu de uma sala de check-in, sala de embarque, corredor de embarque e interior da aeronave. Na Figura 4.1 são mostradas algumas imagens do corredor de embarque, da visão externa do mockup e exemplos de iluminação do interior da cabine. Os passageiros, após receberem instruções, entraram na cabine do mockup, composta de 30 assentos, banheiro, conforme mostrado esquematicamente na Figura 4.2. 


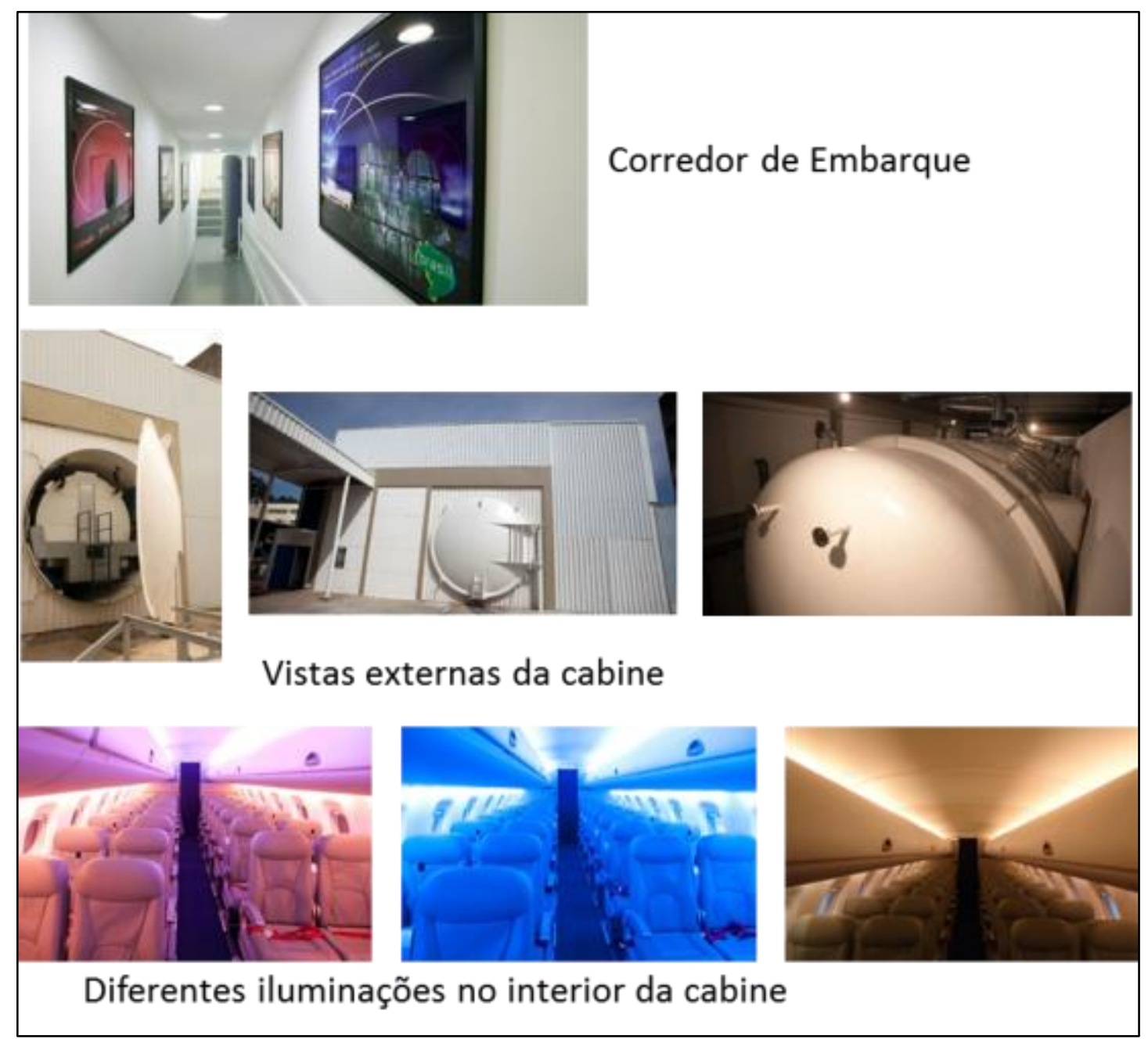

Figura 4.1 Imagens do local e da cabine onde foram realizados os ensaios

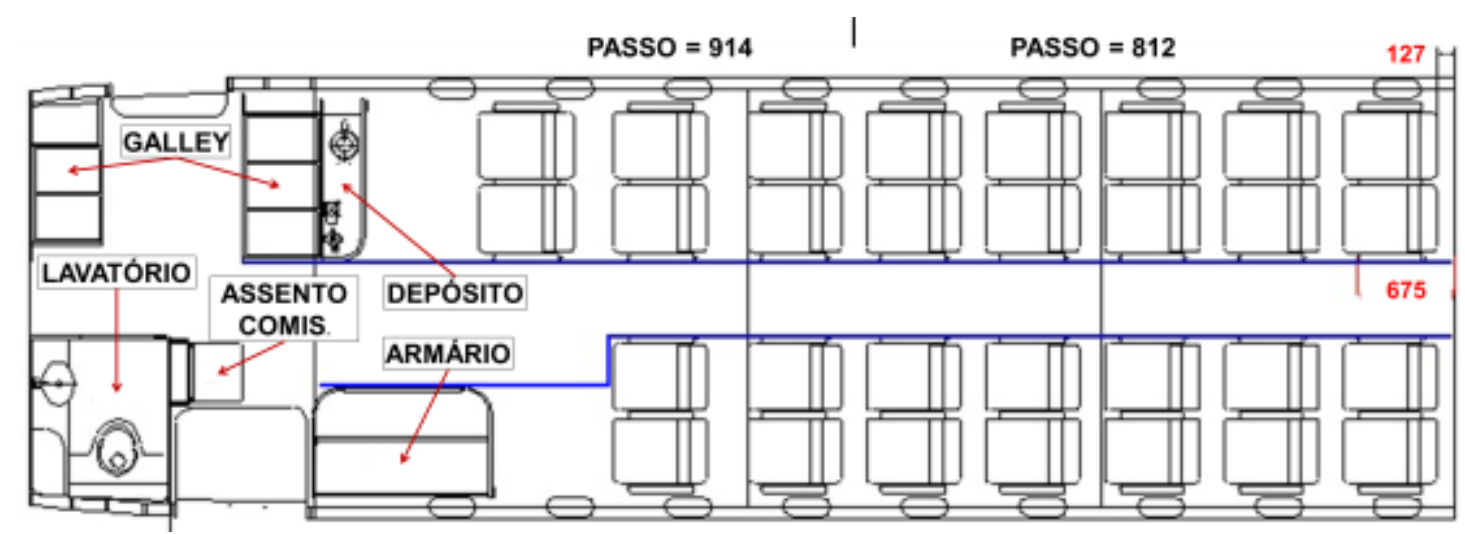

Figura 4.2 Esquema do interior do mockup.

Os assentos foram equipados com mecanismo vibro-acústico para simular as vibrações e nível sonoro de um voo. O sistema de iluminação do mockup sofreu alteração em relação a cabine de um jato comercial - mudou-se a fonte luminosa de lâmpada fluorescente para LED, Lighti-emitting diode, assunto abordado no Apêndice 
A - Tecnologia do Led. Trata-se de um diodo emissor de luz. O sistema de iluminação foi concebido e fornecido pela Diehl Aerospace, com aplicação de LEDS vermelho, azul, verde, branco frio e branco quente. Um controlador fazia as ativações dos LEDS de maneira individualizada e permitia a criação de cenários diferentes de iluminação, em que a cor da luz e a intensidade luminosa eram alterada conforme o interesse. Com essa tecnologia pode-se criar condições particulares para cada fase do voo e, dessa maneira, avaliar o conforto percebido pelos passageiros.

Em função da presente pesquisa ter sido realizada no interior de uma cabine de aeronave é importante apresentar algumas características a respeito de sua iluminação.

A Figura 4.3 ilustra a cabine de passageiros de uma aeronave, com indicações de alguns elementos do seu interior.

- Iluminação da superfície do teto: o teto é iluminado por luzes indiretas para reduzir problemas de ofuscamento.

- Sistema de controle: local com controles de entrada de ar individual e da luz de leitura.

- Modelamento de faces e objetos: a iluminação deve ser tal que não produza distorções cromáticas das faces das pessoas e dos objetos.

- Cor aparente (contraste de cor): a luz incidente nos objetos reproduz as cores aparentes dos objetos e cria contrastes de intensidade e de sombras.

- Luz de leitura: luz que é direcionada para a região de leitura de cada passageiro.

- Fonte/Tarefa/Geometria do olho: a fonte é um visor para informações visuais de alguns detalhes do voo e para entretenimento visual. Tarefa é qualquer atividade que exija atenção visual. A fonte e a tarefa devem estar dispostas dentro do campo visual do passageiro e em uma disposição que satisfaça a geometria do olho. 
- Integração da luz do dia e controle: são janelas individuais que podem ser manuseadas pelos passageiros, permitindo uma visualização do exterior da aeronave e entrada de luz natural.

Dentro da cabine, a iluminação deve capacitar a realização de inúmeras atividades tais como embarcar, localizar o assento, ler, escrever, assistir televisão, dormir, utilizar aparelhos eletrônicos.

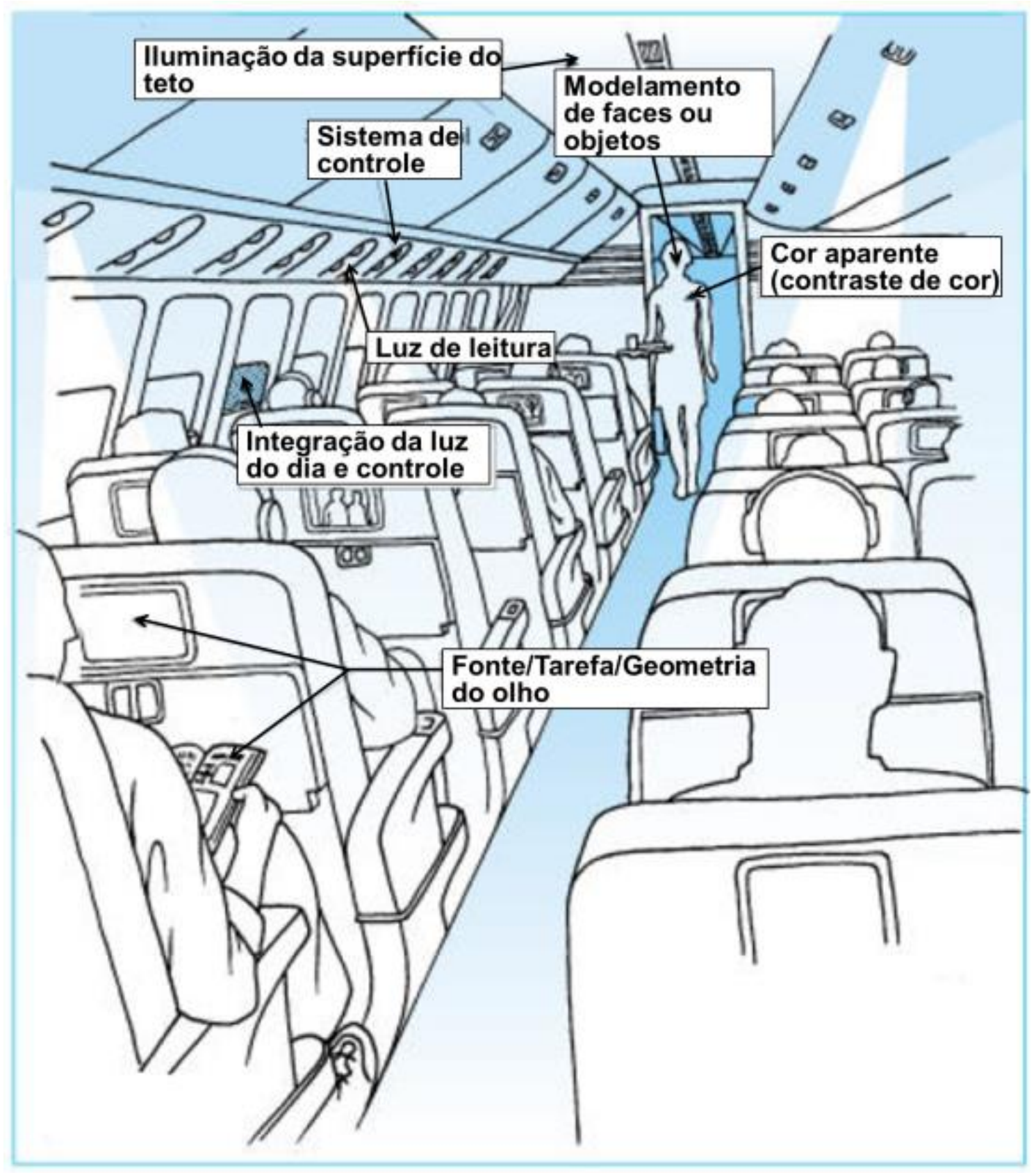

Figura 4.3 Cabine de passageiros de uma aeronave 
Julga-se necessário introduzir os aspectos que devem ser considerados em um projeto de cabine de aeronave, para que se compreenda o contexto desta pesquisa.

- Sistema de controle e Flexibilidade - Se a lluminação requerida para manusear a bagagem for muito intensa, ações como assistir televisão e dormir poderão ser afetadas. Assim, é essencial que a tripulação possa controlar a intensidade da iluminação.

- Controle e integração da luz natural - As janelas da cabine permitem a visualização do cenário externo ao avião. Entretanto, durante o dia também, a luz do sol pode causar ofuscamento. Para minimizar essa situação, é necessário haver janelas com bloqueadores de luz.

- Luz de leitura - A luz de leitura do passageiro deve ser bem localizada. Uma boa posição, boa distribuição da luz e bom ângulo de regulagem ajudam evitar reflexos e sombras nas superfícies de leitura ou escrita.

- Ofuscamento direto - Para haver conforto e visibilidade, a intensidade da iluminação deve ser minimizada nos ângulos de visão da tripulação e passageiros. Para isso é preciso que a iluminação seja indireta e posicionada fora do ângulo de visão do passageiro.

- Luminâncias das superfícies do interior da cabine - A cabine da aeronave é um espaço fechado e limitado. Deve-se considerar luz colorida, de forma que a mesma refletindo nas paredes laterais e teto crie uma percepção do ambiente espaçoso.

- Aparência e contraste da cor - A fonte de luz deve ser escolhida de maneira a ter uma boa reprodução de cor da pele e dos acabamentos do interior da aeronave, a fim de que as imagens percebidas não sofram distorções de cor.

- Delineamento das faces e dos objetos - Uma boa definição das faces melhora a comunicação entre a tripulação e os passageiros. O uso de luz indireta refletida de superfícies coloridas ajuda a eliminar sombras nas faces. 


\subsection{Estudo de Diferencial Semântico}

Como foi apresentado no início do primeiro capítulo, o tema tratado neste trabalho é amplo e pode ser estudado a partir de diferentes abordagens. O conforto lumínico, pode ser avaliado de maneira objetiva e subjetiva. Objetivamente, avalia-se o nível de iluminação por meio de instrumentos específicos que permitem detectar algumas propriedades fotométricas e colorimétricas do ambiente.

No caso desta investigação, pretendeu-se avaliar a percepção de conforto e desconforto causado por diferentes condições de iluminação. Para isso valeu-se de um grupo de pessoas que informou as sensações que a iluminação provocava. Apesar de empregar recursos quantitativos, foi a interpretação do sujeito desta pesquisa - grupo de passageiros - que forneceu dados para serem analisados e avaliados.

Como o estudo está voltado para avaliações subjetivas da sensação de conforto/desconforto em uma cabine de aeronave nas várias fases de voo (entrada, decolagem, cruzeiro, alimentação, descanso, saída), pois utiliza a interpretação e avaliação dos passageiros selecionados, optou-se pelo uso da ferramenta de Diferencial Semântico. A área estudada nesta pesquisa é a percepção que se tem de uma informação visual. Como cada pessoa tem uma interpretação diferente dos sinais que recebe, há dificuldade em saber qual percepção obtida durante determinado estímulo externo. Nesta pesquisa procurou-se encontrar padrões de conforto para diferentes tipos de iluminação. Foi necessário encontrar uma maneira de mensurar essa qualidade de iluminação por meio de relatos de pessoas e criar um método de medição para mensurar a percepção dos passageiros a respeito dos estímulos de iluminação recebidos. Para tanto, aplicou-se o método de Diferencial Semântico.

Conforme Osgood (1975), não há conceitos padronizados nem escalas definidas para a realização dessa metodologia. Os conceitos e as escalas de medição em um estudo específico dependem apenas da finalidade da pesquisa.

A escolha dos termos a serem utilizados no diferencial semântico depende de uma boa seleção para que o objetivo seja atingido. $O$ autor recomenda o emprego de 
alguns critérios: escolher termos que podem gerar consideráveis diferenças individuais; escolher termos com significado único e que não gerem dúvidas de interpretação; escolher termos que são familiares a todos os participantes (OSGOOD et al., 1975, p. 77-78).

Na técnica do Diferencial Semântico (OSGOOD et al., 1975), os entrevistados classificam a força e a direção de um par de adjetivos bipolares. Os pares de adjetivos ficam dispostos de tal maneira que os mesmos são separados por uma linha, que no caso específico deste experimento, é contínua, diferentemente do padrão utilizado em outros estudos, em que a linha de separação entre os pares de adjetivos é tracejada com cinco, sete ou mais segmentos. A técnica exige que o entrevistado coloque uma marca em um ponto Diferencial Semântico (OSGOOD et al., 1975) os entrevistados classificam a força e a dessa linha, indicando assim o grau de importância de determinado adjetivo.

Procurou-se por pesquisas em que essa técnica fosse utilizada e entre os muitos trabalhos encontrados, está o de Veitch e Newsham, (1997). Trata-se de uma investigação a respeito da avaliação do conforto proporcionado pela iluminação empregada em tarefas de escritório. O diferencial semântico foi aplicado, com a utilização de 27 adjetivos bipolares, a saber - gosto/não gosto; agradável/desagradável; bonito/feio; atraente/não atraente; interessante/monótono; colorido/ sem cor; confortável/inconfortável; suave/estimulante; sombrio/radiante; tenso/relaxante; distinto/vago; confuso/organizado; não uniforme/uniforme; constante/cintilante; complexo/simples; brilhante/escuro; gritante/não gritante; quente/frio; acima/periférico; grande/pequeno; dramático/difuso; faces claras/faces obscuras; público/privado; formal/casual; claro/nebuloso.

Outro pesquisador, que também empregou a técnica do diferencial semântico foi Waite (2001), para avaliação da qualidade de iluminação em ambientes de escritório. Waite utilizou em seu trabalho, 16 adjetivos bipolares. São eles: muito confortável/muito desconfortável; muito claro/ muito obscuro (não claro); alerto/letárgico; ordem/desorientado; calmo/muito irritado; atrativo/não atrativo; satisfeito/frustrante; amigável/hostil; alegre/triste; claro/nebuloso; relaxado/tenso; espaçoso/apertado; inspirador/depressivo; positivo/negativo; interessante/monótono; 
brilhante/escuro; igual/desigual; visualmente interessante/visualmente desinteressante; bom/aceitável. Nessa avaliação foi utilizada uma escala de 0 a 5.

Para realização dos ensaios deste estudo, foi preciso determinar quais pares de adjetivos bipolares seriam aplicados. Com base em pesquisas semelhantes (FLYNN et al.,1973) e (FLYNN et al.,1979), partiu-se de uma lista de termos para se averiguar a sua adequação na avaliação de um ambiente de iluminação. Os termos selecionados foram: bonito, definido, espaçoso, visualmente quente, não gosto, rostos nítidos, simples, agradável, ofuscante, favorece a sociabilidade, claro, estimulante, traz satisfação, colorido, funcional, alegre, comum, amigável, harmonioso, atraente, inseguro, confortável, limpo, apertado, sofisticado, tranquilizante, requintado, hostil, confuso, repulsivo.

\subsubsection{Determinação dos pares bipolares}

Depois de feita a escolha dos termos, que posteriormente seriam empregados para a avaliação da cor da iluminação da cabine de aeronave, elaborou-se um questionário com o propósito de verificar se seriam ou não adequados para os ensaios subsequentes. Os termos foram apresentados, em forma de questionário, para 40 voluntários, entre eles, jovens e adultos de faixas etárias diversas. Foi solicitado aos voluntários que avaliassem a importância dos termos com relação a sua apropriação ou não para qualificar a cor da iluminação de um ambiente. $O$ questionário e as respostas obtidas estão na Tabela 4.1 .

$\mathrm{Na}$ Figura 4.4, observa-se os gráficos referentes às repostas fornecidas pelos voluntários e a porcentagem atingida em cada um dos adjetivos selecionados. Cada gráfico descreve o índice obtido para quatro pares de adjetivos. A abscissa representa a importância do termo para qualificar um ambiente com relação à iluminação. Quanto maior o valor mais qualificado é o adjetivo. A ordenada representa a quantidade de pessoas que qualificaram o adjetivo conforme a sua importância. 
Tabela 4.1 - Resultado das respostas do questionário para avaliação se determinados adjetivos são apropriados para qualificar um ambiente com relação à iluminação

\begin{tabular}{|c|c|c|c|c|c|}
\hline \multicolumn{6}{|c|}{$\begin{array}{l}\text { Prezado colaborador. } \\
\text { Como parte da minha pesquisa de mestrado na USP, gostaria de pedir sua colaboração } \\
\text { preenchendo a planilha abaixo. O objetivo é verificar se os termos são apropriados } \\
\text { para qualificar um ambiente com relação à iluminação. Deve-se classificar a importância } \\
\text { do termo em uma escala desde "muito inapropriado" até "muito apropriado". } \\
\text { Sinta-se à vontade para fazer comentários ou adicionar outros termos. } \\
\text { Agradeço a sua colaboração. }\end{array}$} \\
\hline \multicolumn{6}{|c|}{ Coloque um "X" na frente do Sim ou Não, do Masc. ou Fem., conforme sua característica. } \\
\hline \multirow{2}{*}{$\begin{array}{l}\text { Você tem mais } \\
\text { de } 25 \text { anos? }\end{array}$} & Sim & \multirow{2}{*}{$\begin{array}{c}\text { Você } \\
\text { completou o } \\
\text { ensino médio? }\end{array}$} & Sim & \multirow{2}{*}{ Sexo } & \\
\hline & Não & & Não & & \\
\hline
\end{tabular}

-- Marque com um "X", na coluna correspondente, o grau de importância do termo para avaliaç̃ao da iluminaç̃o de um ambiente.

\begin{tabular}{|c|c|c|c|c|c|}
\hline Importância & 1 & 2 & 3 & 4 & 5 \\
\hline Termo & $\begin{array}{c}\text { Muito } \\
\text { inapropriado }\end{array}$ & Inapropriado & Indiferente & Apropriado & $\begin{array}{c}\text { Muito } \\
\text { Apropriado }\end{array}$ \\
\hline Bonito & 5 & 5 & 7 & 19 & 3 \\
\hline Definido & 5 & 8 & 8 & 9 & 9 \\
\hline Espaçoso & 8 & 5 & 10 & 7 & 9 \\
\hline $\begin{array}{l}\text { Visualmente } \\
\text { Quente }\end{array}$ & 1 & 4 & 10 & 18 & 6 \\
\hline Não gosto & 7 & 12 & 10 & 5 & 5 \\
\hline Rostos nítidos & 5 & 3 & 10 & 16 & 5 \\
\hline Simples & 0 & 3 & 12 & 19 & 5 \\
\hline Agradável & 0 & 1 & 0 & 20 & 18 \\
\hline Ofuscante & 5 & 4 & 1 & 9 & 20 \\
\hline $\begin{array}{l}\text { Favorece a } \\
\text { Sociabilidade }\end{array}$ & 0 & 5 & 11 & 16 & 7 \\
\hline Claro & 0 & 0 & 6 & 11 & 22 \\
\hline Estimulante & 1 & 4 & 9 & 10 & 6 \\
\hline Traz satisfacão & 1 & 3 & 9 & 20 & 6 \\
\hline Colorido & 1 & 4 & 8 & 14 & 12 \\
\hline Funcional & 1 & 0 & 2 & 19 & 16 \\
\hline Alegre & 1 & 3 & 12 & 15 & 8 \\
\hline Comum & 2 & 3 & 20 & 10 & 4 \\
\hline Amigável & 3 & 5 & 17 & 11 & 3 \\
\hline Harmonioso & 0 & 1 & 1 & 23 & 14 \\
\hline Atraente & 0 & 2 & 15 & 10 & 6 \\
\hline Inseguro & 15 & 7 & 3 & 9 & 5 \\
\hline Confortável & 0 & 1 & 4 & 17 & 18 \\
\hline Limpo & 4 & 5 & 10 & 14 & 5 \\
\hline Apertado & 13 & 12 & 11 & 2 & 1 \\
\hline Sofisticado & 1 & 1 & 11 & 18 & 7 \\
\hline Tranquilizante & 0 & 2 & 7 & 22 & 8 \\
\hline Requintado & 1 & 2 & 11 & 18 & 7 \\
\hline Hostil & 11 & $\overline{12}$ & 8 & 5 & 3 \\
\hline Confuso & 15 & 10 & 7 & 5 & 2 \\
\hline Repulsivo & 17 & 10 & 4 & 11 & 1 \\
\hline
\end{tabular}


A análise dos gráficos permitiu determinar os termos que foram utilizados no questionário diferencial semântico, entregue aos avaliadores.
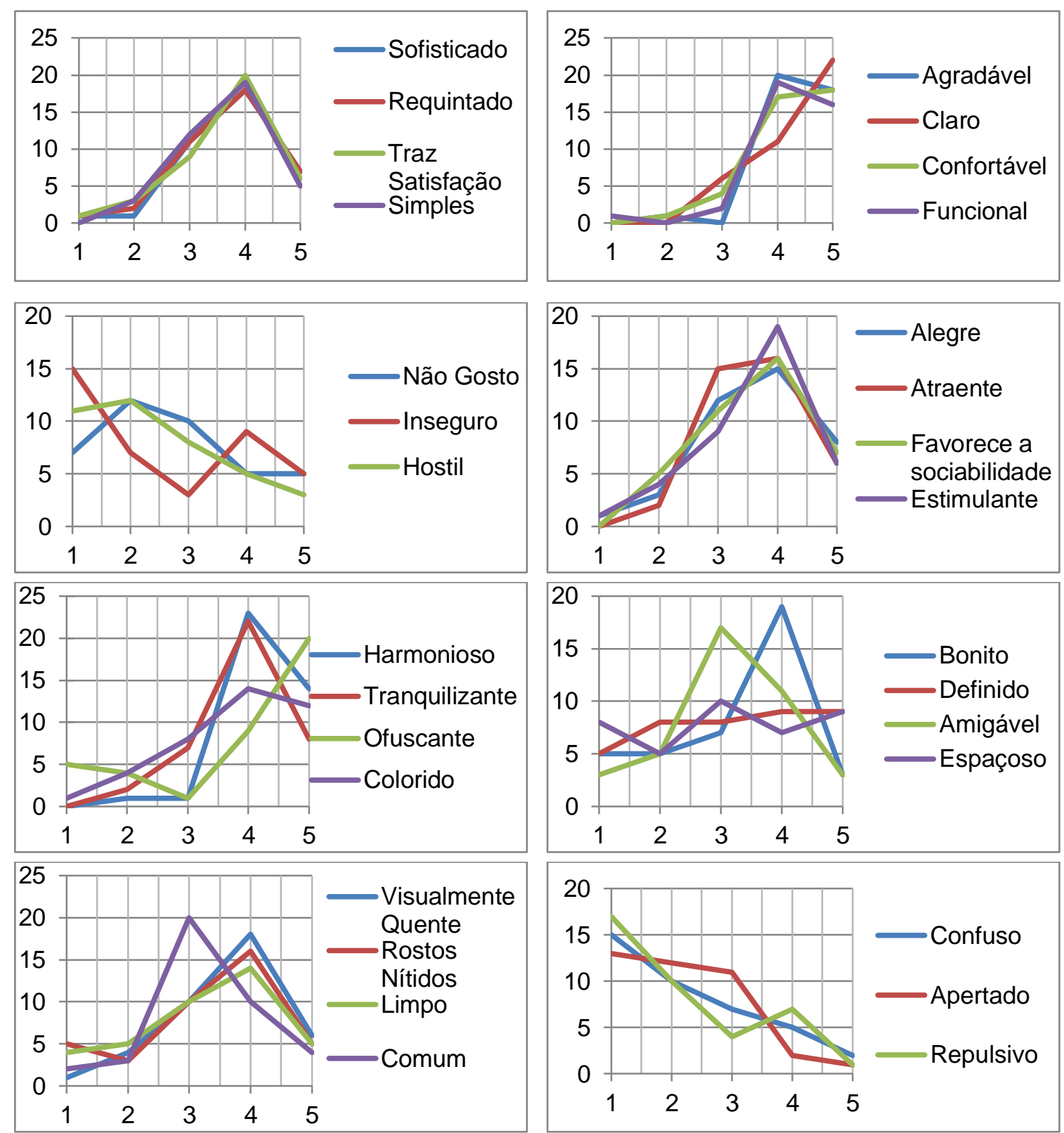

Figura 4.4 - Relação entre quantidade de resposta/importância/adjetivo

Fazendo-se a análise da adequação dos termos, estabeleceram-se os adjetivos bipolares que foram empregados nos ensaios pilotos e integrados, os quais são mostrados na Figura 4.5. Nessa Figura os termos foram ordenados de maneira que os adjetivos do lado esquerdo estão relacionados a conceitos positivos e os do lado direito a conceitos negativos. 
Critérios de Conforto

Questionário de Diferencial Semântico - Ensaios Dedicados de lluminação

ESTUDO: Iluminação Poltrona

Escolha para cada par de adjetivos um ponto na escala que represente a sua opinião, por exemplo, quanto mais LIMPO você achar a cabine iluminada marque mais próximo da palavra LIMPO, quanto mais SUJO você achar a cabine iluminada, marque mais próximo da palavra sujo.

\begin{tabular}{|c|c|c|}
\hline alegre & $L$ & triste \\
\hline bonito & & feio \\
\hline claro & 1 & escuro \\
\hline colorido & 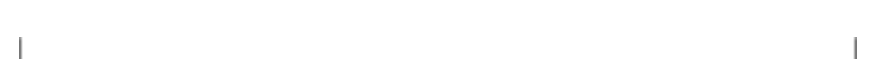 & neutro \\
\hline confortável & 1 & desconfortável \\
\hline estimulante & 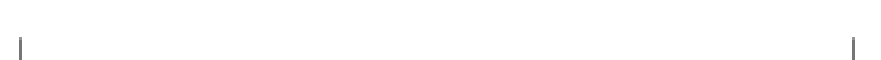 & tranquilizante \\
\hline $\begin{array}{r}\text { favorece a } \\
\text { sociabilidade }\end{array}$ & ل & $\begin{array}{l}\text { não favorece a } \\
\text { sociabilidade }\end{array}$ \\
\hline funcional & 1 & disfuncional \\
\hline harmonioso & & desarmonioso \\
\hline brilhante & & opaco \\
\hline nítido & & distorcido \\
\hline sofisticado & & simples \\
\hline satisfatório & & insatisfatório \\
\hline quente & & frio \\
\hline amplo & & reduzido \\
\hline
\end{tabular}

Figura 4.5 - Questionário final do diferencial semântico aplicado nos ensaios pilotos, dedicados e integrados.

Para efeito de análise e compilação dos dados, estabeleceu-se que os extremos dessa linha seria [0] no extremo esquerdo e [100] no extremo direito. O propósito da aplicação do questionário diferencial semântico foi encontrar tipos de iluminação em que as citações, por parte dos avaliadores, se concentrassem, em grande parte, nos adjetivos bipolares do lado esquerdo da Figura 4.5, tidos como positivos. Assim, se determinada iluminação provocasse a sensação de ambiente frio na cabine da aeronave, o passageiro deveria assinalar, no par bipolar relativo a quente/frio, uma 
marcação mais próxima à palavra frio do que quente. O valor atribuído a essa avaliação obteve-se dividindo a distância de 0 até a marcação, pela distância de 0 a 100 e multiplicando o resultado por 100, conforme exemplificado na Figura 4.6.

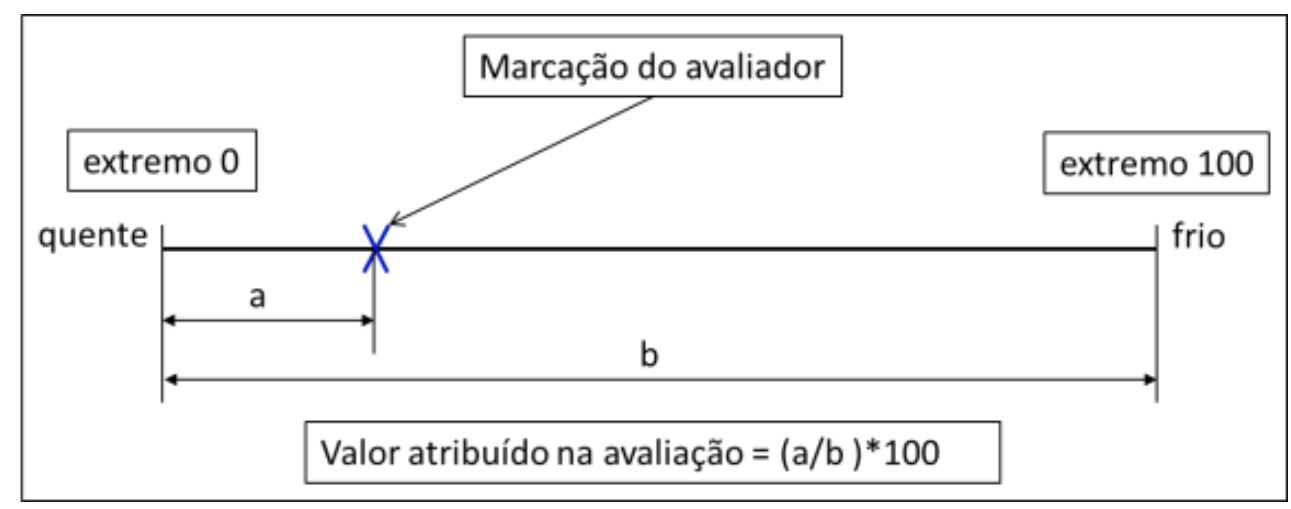

Figura 4.6. Exemplo de marcação e cálculo de uma avaliação de um par de adjetivo bipolar par bipolar

\subsubsection{Definição das cores de iluminação}

Como a característica da iluminação do ambiente depende da fonte luminosa e das propriedades colorimétricos dos objetos que estão presentes nesse ambiente, fez a medição das cores das superfícies do interior da cabine. O equipamento empregado para as medições das cores das superfícies foi um espectrofotômetro Konica Minolta CM-2500c. O funcionamento básico desse equipamento é emitir uma luz com o espectro do iluminante D65, que representa as características da luz ao meio dia na Europa Ocidental, e medir o espectro da luz refletida do objeto. A figura 4.7 mostra o espectro luminoso do iluminante D65 em função do comprimento de onda e a densidade relativa de potência espectral. Na Figura 4.8 são representadas as cores, obtidas por um espectrofotômetro, de algumas superfícies do interior do mockup.

Com relação às características da luz de iluminação do interior do mockup, a mesma foi proveniente de sistema de Leds, CW, RGB, WW (Cold White, Red, Green, Blue, Warm White), com suas características espectrais conhecidas. As informações técnicas desses LEDs estão representadas pela Figuras 4.9, que mostra as curvas espectrais de cada LED em função do comprimento de onda e da intensidade luminosa, e pela Figura 4.10 que mostra a localização das cores dos LEDS em um espaço de Cromaticidade representado pelas coordenadas tricromáticas " $x$ " e " $y$ " conforme CIE 1931. 


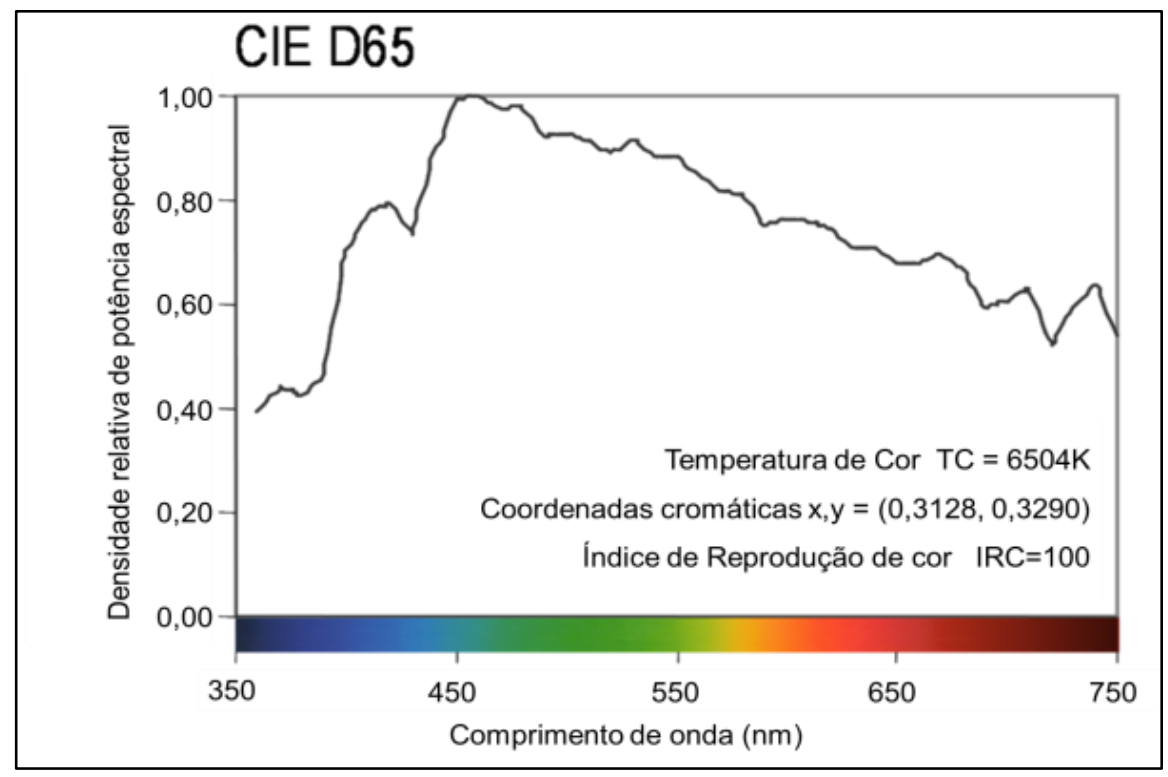

Figura 4.7. Espectro do iluminante D65 (CIE).

\begin{tabular}{|l|l|}
\hline Assento Frontal & \\
\hline Dorso da Mesa & \\
\hline Mesa & \\
\hline Suporte da luz de leitura & \\
\hline Bagageiro & \\
\hline Cortina da Janela & \\
\hline Porta do Bagageiro & \\
\hline Parede Lateral & \\
\hline Teto & \\
\hline Armário & \\
\hline Faixa Dourada do Armário & \\
\hline Carpete & \\
\hline Vermelho de aviso & \\
\hline Vermelho Cinto & \\
\hline
\end{tabular}

Figura 4.8 - Cores obtidas dos objetos no interior da cabine 


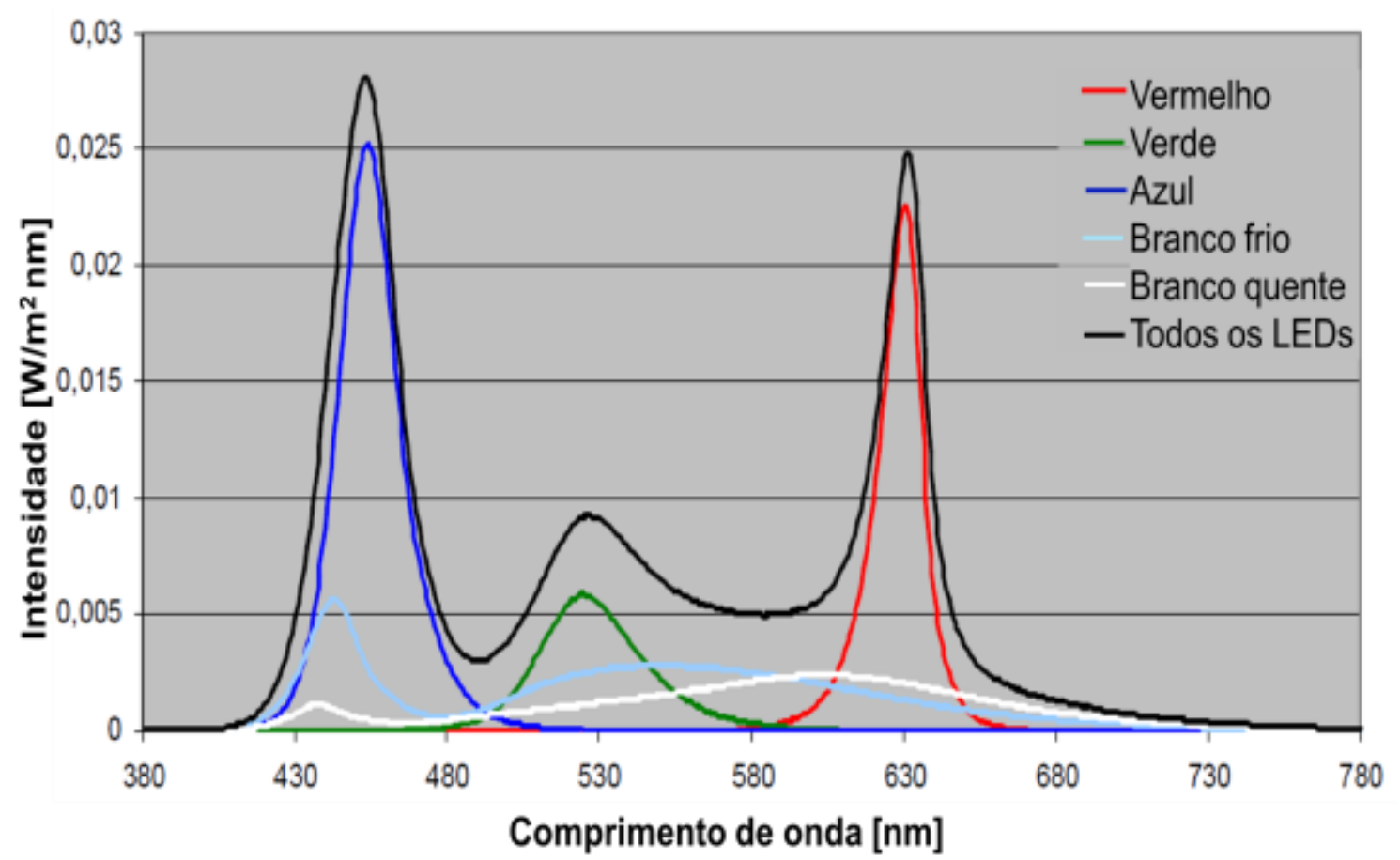

Figura 4.9 - Espectro dos Leds R G B WW CW

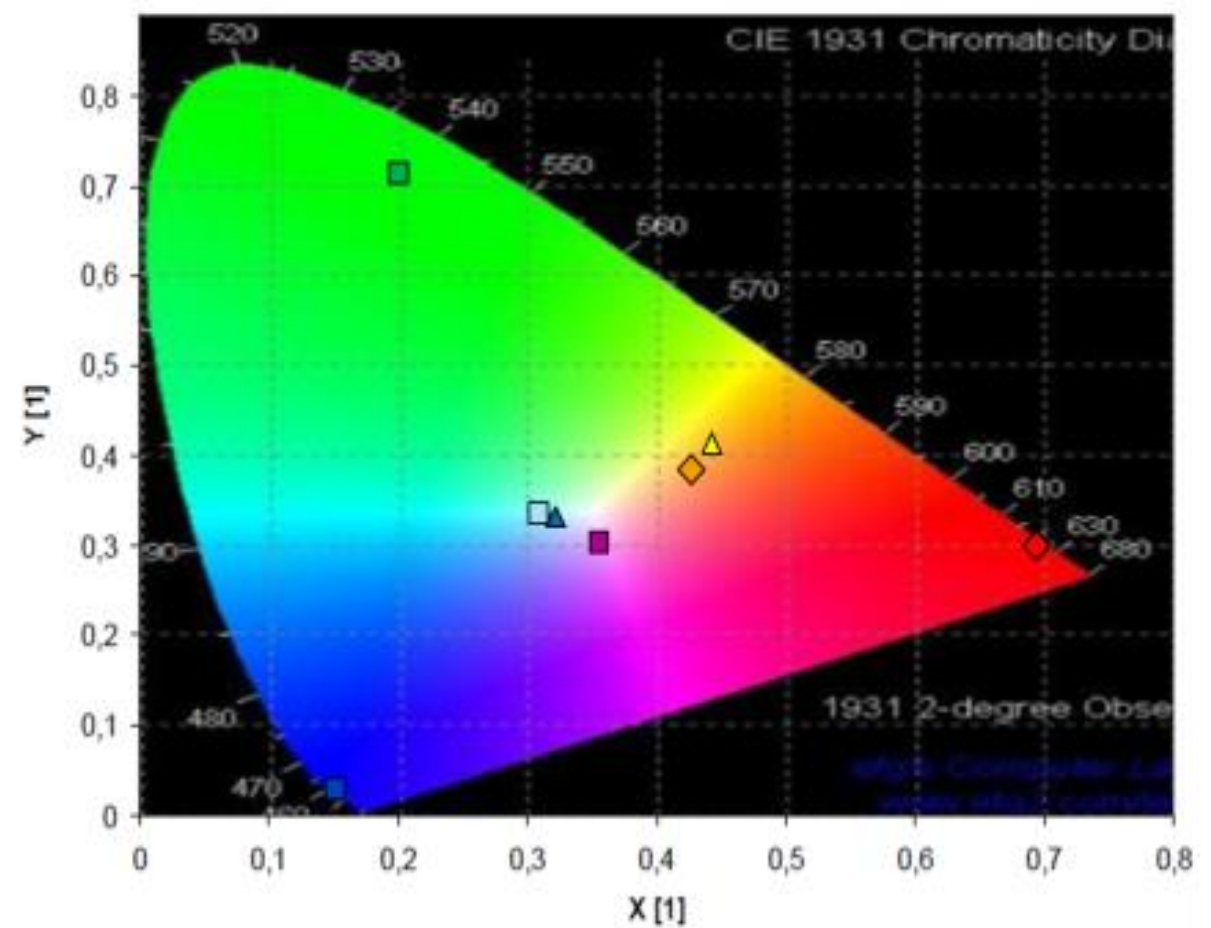

\begin{tabular}{|l|}
\hline Vermelho \\
Verde \\
Azul \\
$\Delta$ Branco Quente \\
$\square$ Branco Frio \\
$\Delta 3000^{\circ}$ Kelvin \\
$4000^{\circ}$ Kelvin \\
$\Delta 6000^{\circ}$ Kelvin \\
\hline
\end{tabular}

Figura 4.10 - Localização das coordenadas das cores dos Leds. 


\subsubsection{Seleção dos avaliadores}

Devido à grande diversidade de transformações e informações visuais de como percebemos os objetos, optou-se por selecionar um grupo de voluntários com diferentes características físicas, tais como sexo, idade e cor dos olhos, como proposto por Veitch e Newsham (1997)

A seleção dos passageiros foi feita através de um banco de dados. Este banco de dados foi criado e aberto ao público. Os candidatos preenchiam um formulário, via internet, fornecendo as seguintes informações: nome, idade, sexo, peso, altura, nacionalidade, escolaridade, escolaridade, renda, cor dos olhos, frequência de viagens aéreas, informações médicas

Para cada ensaio, a população dos participantes foi constituída de maneira tal que satisfizesse o seguinte perfil:

- 50\% homens e $50 \%$ mulheres

- Idade entre 20 e 40 anos

- Não poderiam possuir nenhum tipo de daltonismo

Essa mesma característica dos participantes foi utilizada no experimento realizado por Veitch e Newsham (1997), em que os participantes foram 50\% homens e $50 \%$ mulheres, com idade entre 18 e 61 anos.

Para cada ensaio piloto foram convocados 26 participantes em função da quantidade de assentos disponíveis no interior do mockup. A quantidade de assentos disponíveis no mockup é de 30 assentos, optando-se por deixar 4 assentos livres para o pessoal de apoio e outras eventuais necessidades. O pessoal de apoio que participou dos ensaios no interior da aeronave, denominado de tripulação, tinha a função de orientar os passageiros na realização das atividades programadas nos ensaios, se comunicar com o pessoal do exterior da aeronave, distribuir e recolher os questionários a serem respondidos pelos passageiros, servir refeição, recolher materiais descartáveis (restos da refeição), etc. Basicamente a tripulação tinha a mesma função de uma tripulação de um voo comercial. 


\subsubsection{Ensaios}

Em uma cabine mockup, um grupo de avaliadores foi submetido a diferentes condições ambientais relativas à cor da iluminação e ao visual, em que, após determinado tempo, manifestaram-se a respeito de suas sensações de conforto/desconforto, por meio da aplicação do questionário.

Os ensaios destinaram-se à verificação da sensação dos passageiros com relação ao aspecto da cor da iluminação do interior de uma cabine de aeronave

As pessoas que participaram dos ensaios ficaram sujeitas à simulação de algumas condições reais de voo, tais como redução de pressão simulando condições de altitude da aeronave e vibração/ruído simulando condições de decolagem e cruzeiro de uma aeronave.

\subsubsection{Preparação para a análise dos resultados}

Para se fazer a análise estatística dos resultados criou-se uma tabela com os seguintes itens: data/ número de ensaio piloto, número do assento, par bipolar e a fase do voo. Nas células da tabela colocaram-se os valores indicados pelos avaliadores. Com essa tabela pode-se gerar gráficos que permitiram a análise dos resultados. A tabela 4.2 é um exemplo do trabalho descrito, com os valores (de 0 a 100) auferidos pelos avaliadores. 
Tabela 4.2 - Exemplo de resultados obtidos na fase de Embarque. A escala de valores vai de 0 a 100.

\begin{tabular}{|c|c|c|c|c|c|c|c|c|c|c|c|c|c|c|c|c|}
\hline & & \multicolumn{15}{|c|}{ Embarque AZUL } \\
\hline & 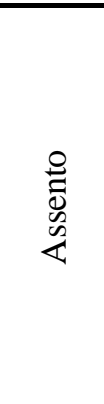 & 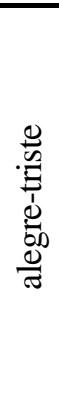 & 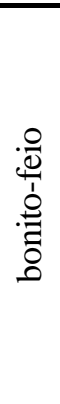 & 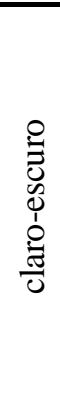 & $\begin{array}{l}\stackrel{0}{0} \\
0 \\
0 \\
0 \\
0 \\
0 \\
0 \\
0 \\
0\end{array}$ & 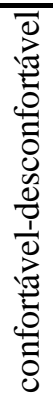 & 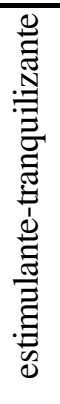 & 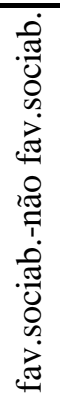 & 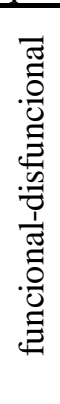 & 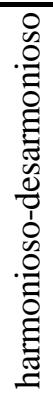 & 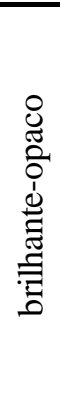 & 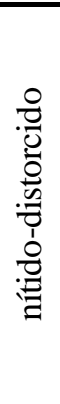 & 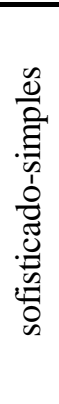 & 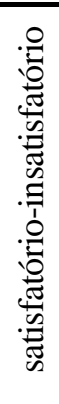 & 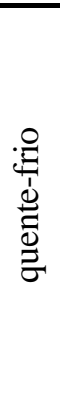 & 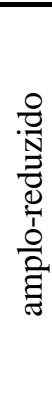 \\
\hline \multirow{19}{*}{ 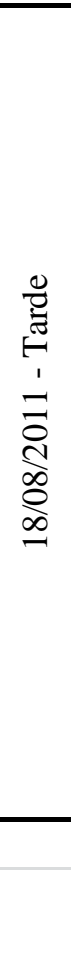 } & $2 \mathrm{C}$ & 20 & 7 & 34 & 45 & 10 & 61 & 68 & 68 & 27 & 67 & 75 & 23 & 27 & 34 & 20 \\
\hline & $3 \mathrm{~A}$ & 49 & 31 & 72 & 59 & 30 & 82 & 48 & 50 & 20 & 50 & 62 & 23 & 25 & 73 & 40 \\
\hline & $3 B$ & 47 & 26 & 57 & 91 & 17 & 90 & 10 & 5 & 8 & 52 & 7 & 47 & 4 & 49 & 49 \\
\hline & $3 \mathrm{C}$ & 44 & 11 & 67 & 77 & 20 & 80 & 52 & 20 & 20 & 49 & 69 & 49 & 23 & 49 & 50 \\
\hline & $3 \mathrm{D}$ & 23 & 23 & 77 & 59 & 14 & 20 & 8 & 8 & 8 & 42 & 41 & 6 & 22 & 23 & 11 \\
\hline & $4 \mathrm{~A}$ & 80 & 36 & 76 & 80 & 79 & 80 & 70 & 56 & 47 & 83 & 76 & 33 & 66 & 41 & 87 \\
\hline & $4 \mathrm{~B}$ & 40 & 21 & 37 & 78 & 40 & 47 & 69 & 22 & 21 & 50 & 34 & 64 & 7 & 45 & 60 \\
\hline & $4 \mathrm{C}$ & 52 & 78 & 83 & 98 & 79 & 50 & 51 & 77 & 65 & 21 & 77 & 33 & 72 & 73 & 30 \\
\hline & $4 \mathrm{D}$ & 3 & 5 & 12 & 90 & 8 & 84 & 11 & 18 & 13 & 17 & 9 & 12 & 9 & 51 & 48 \\
\hline & $5 \mathrm{~A}$ & 49 & 50 & 51 & 87 & 49 & 26 & 17 & 20 & 52 & 83 & 85 & 86 & 27 & 50 & 90 \\
\hline & 5B & 50 & 50 & 57 & 29 & 62 & 26 & 49 & 49 & 49 & 38 & 53 & 48 & 56 & 49 & 25 \\
\hline & $5 \mathrm{D}$ & 40 & 53 & 49 & 69 & 32 & 77 & 50 & 39 & 35 & 67 & 50 & 63 & 38 & 55 & 42 \\
\hline & $6 \mathrm{~A}$ & 6 & 16 & 6 & 40 & 40 & 41 & 40 & 34 & 16 & 15 & 14 & 45 & 26 & 37 & 37 \\
\hline & $6 \mathrm{~B}$ & 17 & 7 & 10 & 20 & 9 & 84 & 22 & 13 & 22 & 22 & 24 & 16 & 17 & 48 & 39 \\
\hline & $6 \mathrm{D}$ & 38 & 30 & 30 & 62 & 70 & 72 & 59 & 72 & 21 & 27 & 34 & 36 & 50 & 70 & 30 \\
\hline & $7 \mathrm{D}$ & 20 & 9 & 18 & 39 & 23 & 34 & 15 & 39 & 25 & 38 & 14 & 15 & 21 & 40 & 34 \\
\hline & $8 \mathrm{D}$ & 19 & 20 & 21 & 25 & 11 & 17 & 16 & 19 & 20 & 22 & 22 & 41 & 20 & 41 & 25 \\
\hline & Média & 35 & 28 & 45 & 62 & 35 & 57 & 39 & 36 & 28 & 44 & 44 & 38 & 30 & 49 & 42 \\
\hline & $\begin{array}{c}\text { Desv } \\
\text { Pad }\end{array}$ & 20 & 20 & 26 & 25 & 25 & 26 & 23 & 23 & 16 & 22 & 27 & 21 & 20 & 13 & 21 \\
\hline
\end{tabular}

Explicados os procedimentos metodológicos e critérios empregados nesta investigação, passa-se agora, no próximo capítulo, à análise dos resultados obtidos. 


\section{RESULTADOS DOS ENSAIOS}

Neste capítulo serão apresentados e discutidos os resultados obtidos dos ensaios pilotos realizados.

\subsection{Apresentação do locus experimental}

Foram realizados cinco ensaios pilotos. O objetivo dos ensaios pilotos foi o de fornecer parâmetros para a determinação das cores a serem aplicadas nos ensaios integrados. O grupo de passageiros que participou desses experimentos seguiu um roteiro que é apresentado a seguir.

Para que os passageiros pudessem participar da pesquisa, recomendou-se que os mesmos chegassem 1 hora antes do horário estipulado para o ensaio. Após se apresentarem no balcão de check-in, eles se identificaram para, em seguida, receber o cartão de embarque com o número da poltrona que ocupariam na cabine do avião durante o voo. Dirigiram-se, então, à sala de embarque onde aguardaram a autorização para o embarque. Nessa sala os passageiros receberam instruções das etapas do voo e das tarefas a serem executadas durante o ensaio. Após o embarque de todos os passageiros e da tripulação, a porta do mockup era trancada e a cabine climatizada.

Com base nas condições de conforto térmico (ASHRAE), o sistema de ar condicionado foi ajustado para as seguintes condições:

- Temperatura do liner (parede interna lateral): $19^{\circ} \mathrm{C}$

- Temperatura da cabine: $21,5^{\circ} \mathrm{C}$

- Temperatura do gasper (saída de ar individual): $21,5^{\circ} \mathrm{C}$

- Umidade relativa do ar: $50 \%$

Além do ar condicionado, também foram ajustados a pressão, o nível de ruído e o nível de vibração, para cada fase do voo, com intensidades semelhantes aos de um voo real realizado em jatos comerciais 170 e 190 da EMBRAER.

O voo foi dividido nas seguintes fases: Embarque, Cruzeiro 1, Serviço de Bordo, Cruzeiro 2 e Desembarque. Os avaliadores das condições de conforto causado pela 
cor da iluminação deveriam preencher um questionário Diferencial Semântico após cada fase.

Criou-se um perfil de voo, mostrado na Tabela 5.1, com tempos determinados para cada etapa - 10 minutos foram destinados para a entrada na cabine, 5 minutos para a decolagem, 20 minutos para o cruzeiro 1, 30 minutos para o serviço de bordo, 20 minutos para o cruzeiro 2, 5 minutos para o pouso e 10 minutos para o desembarque. Após cada etapa, os passageiros tinham 5 minutos para responder as questões dos adjetivos a respeito da percepção que tiveram nas condições de iluminação de determinada fase. A troca da cor da iluminação poderia ser feita dimerizada ou não.

Supõe-se que a mudança brusca de uma condição de iluminação para outra gera desconforto. Nesta experiência criou-se um recurso de mudança de cor da iluminação em que era possível controlar o tempo entre as mudanças de condições de iluminação de maneira não abrupta, com dimerização (CD), o que se supunha que resultaria em atmosfera mais tranquila.

Para a aplicação dos ensaios, foram estabelecidos cenários de iluminação com o espectro luminoso da luz proveniente dos LEDs nas cores brancas e coloridas. Procurou-se avaliar a percepção da qualidade de iluminação para 3 diferentes tons de branco e para 2 cores coloridas. A cor branca foi escolhida pois é a cor normalmente utilizada na iluminação da cabine das aeronaves atuais, e dessa maneira pôde-se avaliar a qualidade percebida dessa iluminação. Para a cor branca também avaliou-se 3 temperaturas de cor (quente, normal e frio). A cor de iluminação em tom azul foi escolhida pois, conforme a literatura, é uma cor de relaxamento. A cor de iluminação em tom laranja foi escolhida, pois, dentre alguns dos seus significados, tem a característica de estimular a conversa, propiciar conforto e estimular o apetite. As cores empregadas foram denominadas conforme abaixo:

Temperatura de cor de 3000K (branco quente)

Temperatura de cor de 4000K (branco quente)

Temperatura de cor de 6000K (branco frio)

Laranja

Azul 
Tabela 5.1 Perfil do

\begin{tabular}{|c|c|c|c|}
\hline $\begin{array}{l}\text { Sequência } \\
\text { do ensaio }\end{array}$ & Iluminação & $\begin{array}{c}\text { Tempo } \\
(\mathrm{min})\end{array}$ & Descriçăo \\
\hline $\begin{array}{l}\text { Entrada na } \\
\text { cabine }\end{array}$ & Acesa & 10 & $\begin{array}{c}\text { Entrada dos voluntários e briefing de } \\
\text { boas vindas da comissária. }\end{array}$ \\
\hline Decolagem & $\begin{array}{l}\text { Acesa na cabine e } \\
\text { Galley e desligada }\end{array}$ & 5 & - \\
\hline Questionário & Acesa & 5 & Questionário Diferencial Semântico \\
\hline Dimerizaçăo & $\mathrm{CD}$ & - & - \\
\hline Cruzeiro 1 & Acesa & 20 & Atividade livre. \\
\hline Avaliaçăo & Acesa & 5 & Questionário Diferencial Semântico \\
\hline Dimerizaçăo & $\mathrm{CD}$ & - & - \\
\hline $\begin{array}{l}\text { Serviço de } \\
\text { bordo }\end{array}$ & Acesa & 30 & Lanche \\
\hline Avaliação & Reduzida & 5 & Questionário Diferencial Semântico \\
\hline Dimerizaçăo & CD & - & - \\
\hline Cruzeiro 2 & Acesa & 20 & Atividade livre. \\
\hline Avaliaçăo & Acesa & 5 & Questionário Diferencial Semântico \\
\hline Dimerizaçăo & $\mathrm{CD}$ & - & - \\
\hline Pouso & $\begin{array}{c}\text { Acesa na cabine e } \\
\text { Galley desligada }\end{array}$ & 5 & - \\
\hline $\begin{array}{l}\text { Saida da } \\
\text { aeronave }\end{array}$ & Acesa & 10 & \\
\hline Avaliaçăo & Acesa & 5 & $\begin{array}{l}\text { Realizar avaliaçăo na sala de } \\
\text { embarque. } \\
\text { Questionário Diferencial Semântico }\end{array}$ \\
\hline & Total: & 125 & \\
\hline
\end{tabular}

\subsection{Ensaio Piloto}

Foram realizados 5 ensaios pilotos com os cenários de iluminação conforme apresentado na Tabela 5.2, nos quais as cores, azul e laranja foram alternadas em 4 dos ensaios e as cores branco $6000 \mathrm{~K}$, branco $4000 \mathrm{~K}$ e branco $3000 \mathrm{~K}$, empregadas em 1 dos ensaios. É importante explicar que há infinitas possibilidades de cromas de cores de iluminação que poderiam ser aplicados às fases do voo. No entanto, em função do tempo destinado a esta pesquisa, elegeu-se, como citado anteriormente, cinco cores. Considerando-se as cinco fases do voo e as cinco cores selecionadas para este trabalho, o número total de combinação de fases e de cores seria 3.125 
ambientações lumínicas da cabine de avião, o que tornaria esta pesquisa inviável. Apenas para curiosidade, se fossem feitos 2 ensaios diários, seriam necessários, ao menos 4 anos para concluir o levantamento de dados. Por esse motivo a quantidade de combinações da cor da iluminação foi reduzida a cinco, equivalente ao número de ensaios estabelecidos.

Para o as fases de Embarque e Cruzeiro, que são fases de apreensão, novidade, curiosidade, procura dos assentos, guarda de objetos, avaliou-se a percepção da qualidade da iluminação nas cores azul, laranja e branco frio. Para a fase Serviço de Bordo, optou-se pela cor laranja e pelo branco normal, pois é a fase em que os passageiros fazem a refeição. Para o Cruzeiro 2, optou-se pela iluminação em tom azul com o intuito de relaxamento. Para a fase de Desembarque verificou-se a influência das cores de iluminação nos tons laranja, azul e branco frio.

Tabela 5.2 Cenários de iluminação aplicados nos ensaios

\begin{tabular}{|c|c|c|c|c|c|c|}
\hline Ensaio & Data & $\begin{array}{c}\text { Embar- } \\
\text { que }\end{array}$ & $\begin{array}{c}\text { Cruzeiro } \\
\mathbf{1}\end{array}$ & $\begin{array}{c}\text { Serviço de } \\
\text { Bordo }\end{array}$ & $\begin{array}{c}\text { Cruzeiro } \\
\mathbf{2}\end{array}$ & $\begin{array}{c}\text { Desembar } \\
\text { que }\end{array}$ \\
\hline $\mathbf{1}$ & $\begin{array}{c}18 / 08 / 11 \\
\text { Tarde }\end{array}$ & Azul & Azul & Laranja & Azul & Laranja \\
\hline $\mathbf{2}$ & $17 / 08 / 11$ & Azul & Laranja & Laranja & Azul & Azul \\
\hline $\mathbf{3}$ & $12 / 08 / 11$ & Laranja & Azul & Laranja & Azul & Azul \\
\hline $\mathbf{4}$ & $\begin{array}{c}25 / 11 / 11 \\
\text { Manhã }\end{array}$ & Laranja & Laranja & Laranja & Azul & Azul \\
\hline $\mathbf{5}$ & $\begin{array}{r}25 / 11 / 11 \\
\text { Tarde }\end{array}$ & Branco & Branco & Branco & Branco & Branco \\
& $6000 \mathrm{~K}$ & $4000 \mathrm{~K}$ & $3000 \mathrm{~K}$ & $4000 \mathrm{~K}$ & $6000 \mathrm{~K}$ \\
\hline
\end{tabular}

\subsubsection{Resultados}

Com os resultados obtidos dos questionários de diferencial semântico dos cinco ensaios realizados, fez-se uma análise dos mesmos, agrupando-se os dados por fase de voo e por cor de ensaio. A Tabela 5.3 é o resultado da compilação da Tabela 3.1.2 agrupando os ensaios por fase de voo e por cor. 
Tabela 5.3 Cenários de iluminação aplicados nos ensaios e agrupados

\begin{tabular}{|c|c|c|c|c|}
\hline Embarque & Cruzeiro 1 & $\begin{array}{c}\text { Serviço de } \\
\text { Bordo }\end{array}$ & Cruzeiro 2 & Desembarque \\
\hline Azul & Azul & Laranja & Azul & Laranja \\
\cline { 1 - 1 } \cline { 5 - 6 } Laranja & Laranja & & Azul \\
\hline Branco & Branco & Branco & Branco & Branco 6000K \\
$6000 \mathrm{~K}$ & $4000 \mathrm{~K}$ & $3000 \mathrm{~K}$ & $4000 \mathrm{~K}$ & \\
\hline
\end{tabular}

Em decorrência da assimetria da visão humana, aliada ao fato da cabine da aeronave não ser homogênea visualmente, a análise dos resultados levou em conta a localização dos passageiros. Verificou-se também a influência da localização dos passageiros na percepção de conforto/desconforto quando sentados ao lado das janelas do avião ou sentados ao lado do corredor.

$\mathrm{Na}$ análise dos resultados dos ensaios também se averiguou a possível influência de percepção da iluminação em função do passageiro ser homem ou mulher; se pessoas com olhos claros percebem o ambiente iluminado de maneira diferente de pessoas de olhos escuros; e também se o Índice de Massa Corporal (IMC), que é a relação entre o peso em $\mathrm{kg}$ e o quadrado da altura da pessoa em metros, tem influência na percepção da iluminação.

IMC = Peso/(altura*altura) em $\quad(\mathrm{kg} / \mathrm{m} 2)$. Pessoas com IMC>25 são consideradas pessoas com sobrepeso.

Para a análise, levando-se em considerações algumas características físicas dos indivíduos, dividiu-se o público selecionado da seguinte maneira:

- Gênero: Feminino e Masculino

- Cor dos Olhos: Claros (verdes e azuis) e Escuros (castanhos e pretos)

- Índice de Massa Corporal (IMC): IMC<25 e IMC>25

Para a interpretação do diferencial semântico, consideraram-se pontuações abaixo de 40 pontos e acima de 60 pontos como sendo significativos, indicando que há uma tendência para um determinado adjetivo de um par de adjetivos avaliado. Pontuações 
entre 40 e 60 pontos considerou-se como sendo neutras, não havendo tendências para um determinado adjetivo de par de adjetivos avaliado, sendo essa faixa considerada em função do desvio padrão que é em torno de 20 pontos.

Os resultados desta análise são apresentados a seguir.

\subsubsection{Embarque}

Nessa fase as pessoas avaliaram a influência da cor da iluminação no uso dos bagageiros e localização dos assentos.

As médias obtidas dos diferenciais semânticos são apresentadas da Figura 5.1 até a Figura 5.12. Nestas figuras o eixo da abcissa representa as médias obtidas considerando valores de 0 a 100 pontos e a ordenada representa os pares de adjetivos. Para cada par de adjetivos, valores abaixo de 50 pontos são valores mais próximos de adjetivos do lado esquerdo da escala e valores acima de 50 pontos são valores mais próximos de adjetivos do lado direito da escala.

Independente das cores da luz aplicada, o ambiente foi considerado tranquilizante, neutro, bonito, harmonioso, sofisticado, funcional, confortável, nítido, claro, alegre, favorece a sociabilidade, pois os valores destes adjetivos ficaram ou abaixo de 40 pontos ou acima de 60 pontos. Uma iluminação na cor azul (figura 5.1) deixa o ambiente mais brilhante/sofisticado, ao passo que na cor laranja (Figura 5.2) e branca 6000K (Figura 5.3) deixa o ambiente opaco/simples.

As médias das avaliações das pessoas sentadas ao lado da janela foram diferentes do que as médias das pessoas sentadas próximas ao corredor, o que implica em uma não uniformidade da distribuição da luz na cabine da aeronave. Porém para a cor azul não houve diferença.

Analisando-se as respostas dos questionários, observa-se, de uma maneira geral, que a distribuição dos valores atribuídos para os adjetivos bipolares se mantem para os diferentes dias de ensaios, ou seja, para populações diferentes. 
Verifica-se também um desvio padrão de valores em torno de 20 pontos, o que denota uma diferença grande de opiniões dos passageiros para um mesmo diferencial semântico.

Considerando-se os aspectos físicos dos indivíduos, notam-se algumas diferenças significativas de percepção do homem em relação à mulher. Para a cor azul (Figura 5.4) o homem considera o ambiente mais distorcido/opaco/escuro/reduzido do que a mulher. Para a cor laranja (Figura 5.5) o gênero masculino considera a iluminação do ambiente mais escura do que o feminino. Para uma iluminação branco 6000K, (Figura 5.6) o homem, em relação à mulher, considera que esta iluminação deixa o ambiente mais desarmonioso/não favorece a sociabilidade/amplo/quente/colorido.

Com relação à cor dos olhos, algumas diferenças significativas dos resultados ocorreram em função da cor da iluminação. Para a cor azul (Figura 5.7), as pessoas com olhos escuros caracterizaram a cor da iluminação do ambiente, comparando-se com as pessoas de olhos claros, como sendo mais bonito/harmonioso/nítido/ não favorece a sociabilidade/ brilhante/ amplo/ sofisticado/ tranquilizante. Para a cor laranja (Figura 5.8), as pessoas com olhos escuros pontuaram a cor da iluminação com valores maiores do que as pessoas com olhos claros para os adjetivos não favorece a sociabilidade e simples. Para a cor de iluminação branco 6000K (Figura 5.9), as pessoas com olhos escuros caracterizaram o ambiente mais claro/ desarmonioso/ não favorece a sociabilidade/ desconfortável/ amplo/ quente/ brilhante do que as pessoas possuidoras de olhos claros.

Com relação ao IMC, não houve diferenças para as cores de iluminação azul (Figura 5.10) e laranja (Figura 5.11). Para a cor branca 6000K (Figura 5.12), pessoas com $I M C>25$, comparando-se com pessoas com IMC $<25$, consideraram o ambiente mais distorcido/ insatisfatório/ escuro/ desarmonioso/ feio/ favorece a sociabilidade/ brilhante/ sofisticado/ estimulante. 


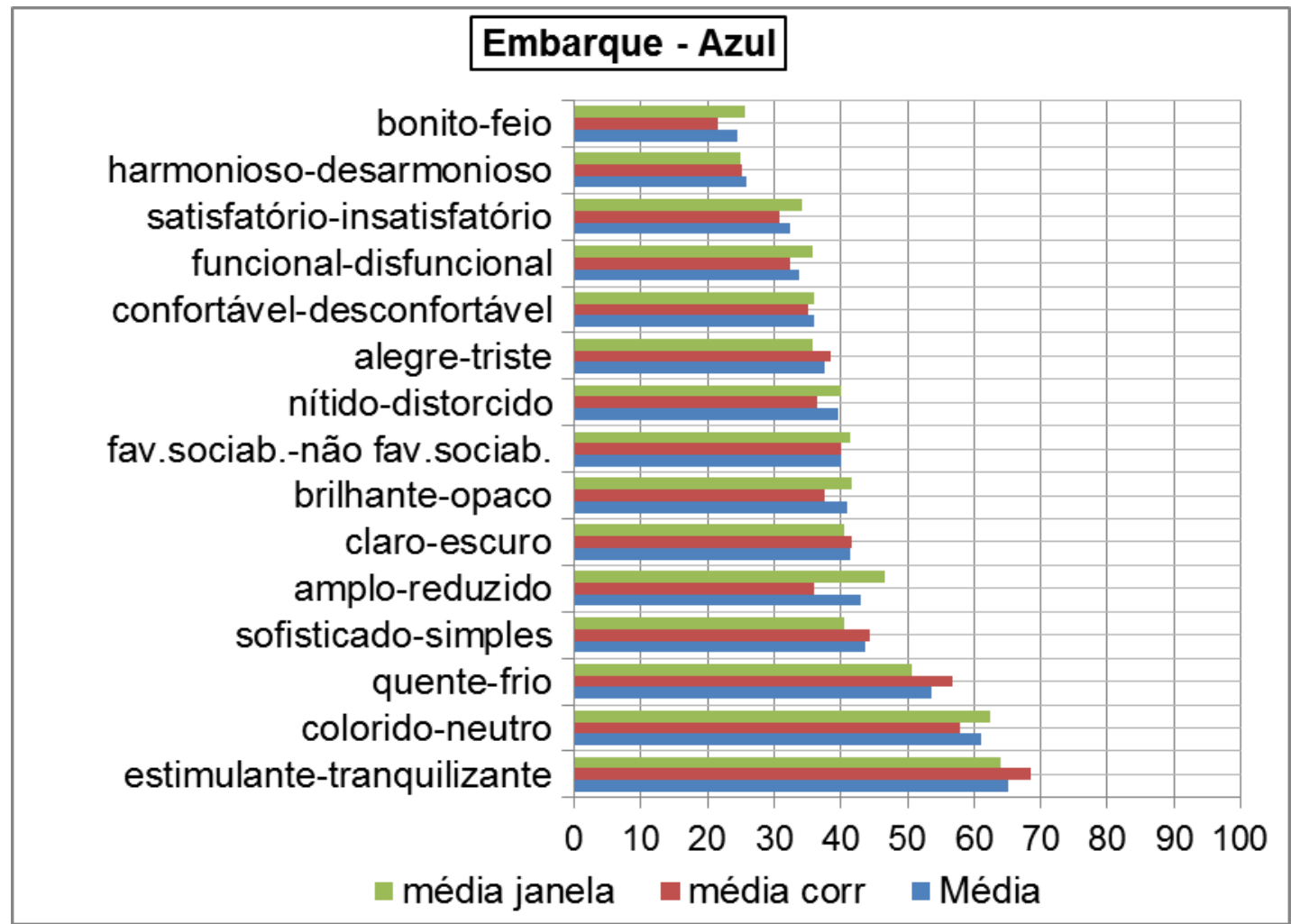

Figura 5.1 Médias obtidas dos diferenciais semânticos para o Embarque cor da iluminação Azul

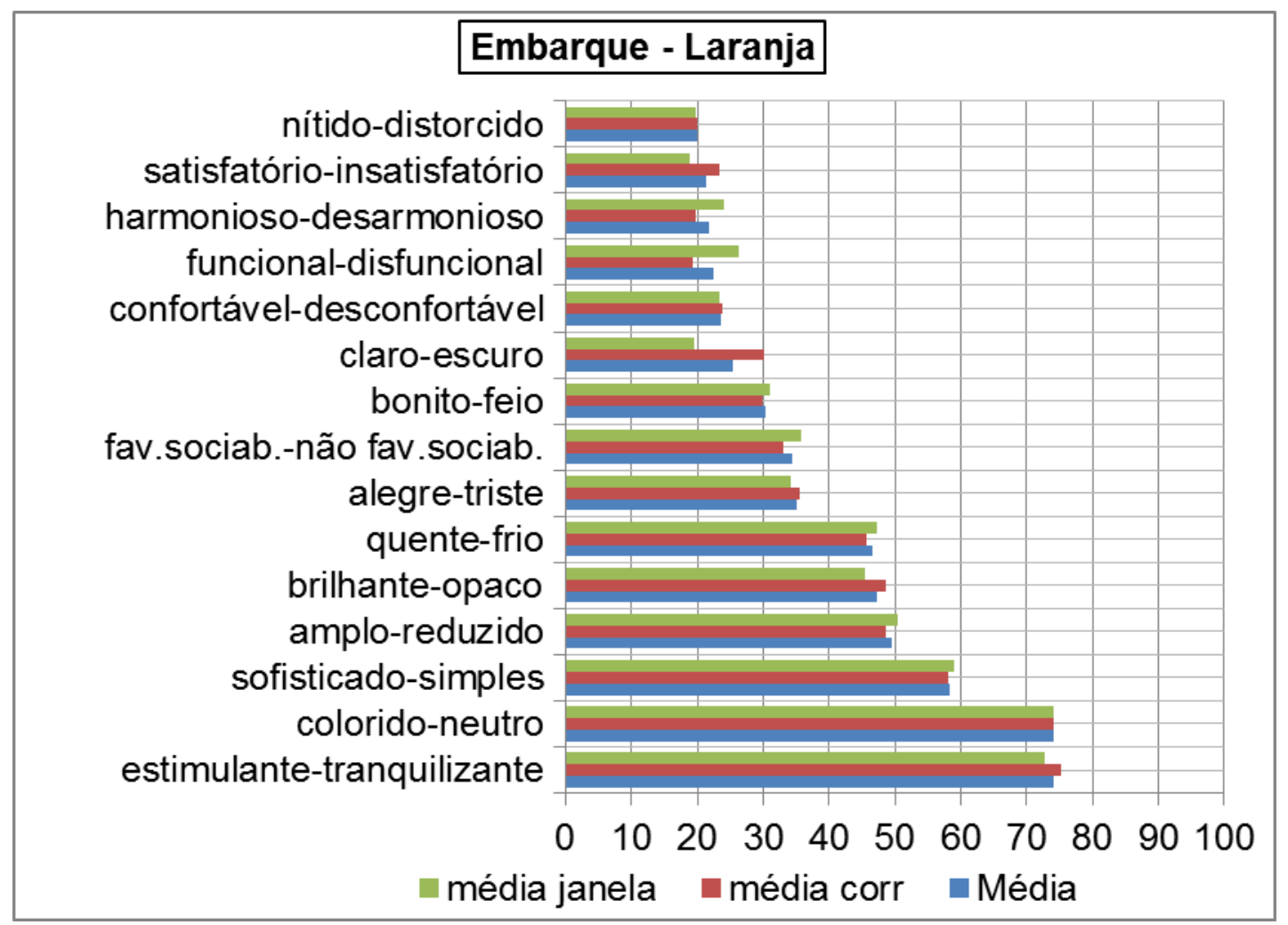

Figura 5.2 Médias obtidas dos diferenciais semânticos para o Embarque cor da iluminação Laranja 


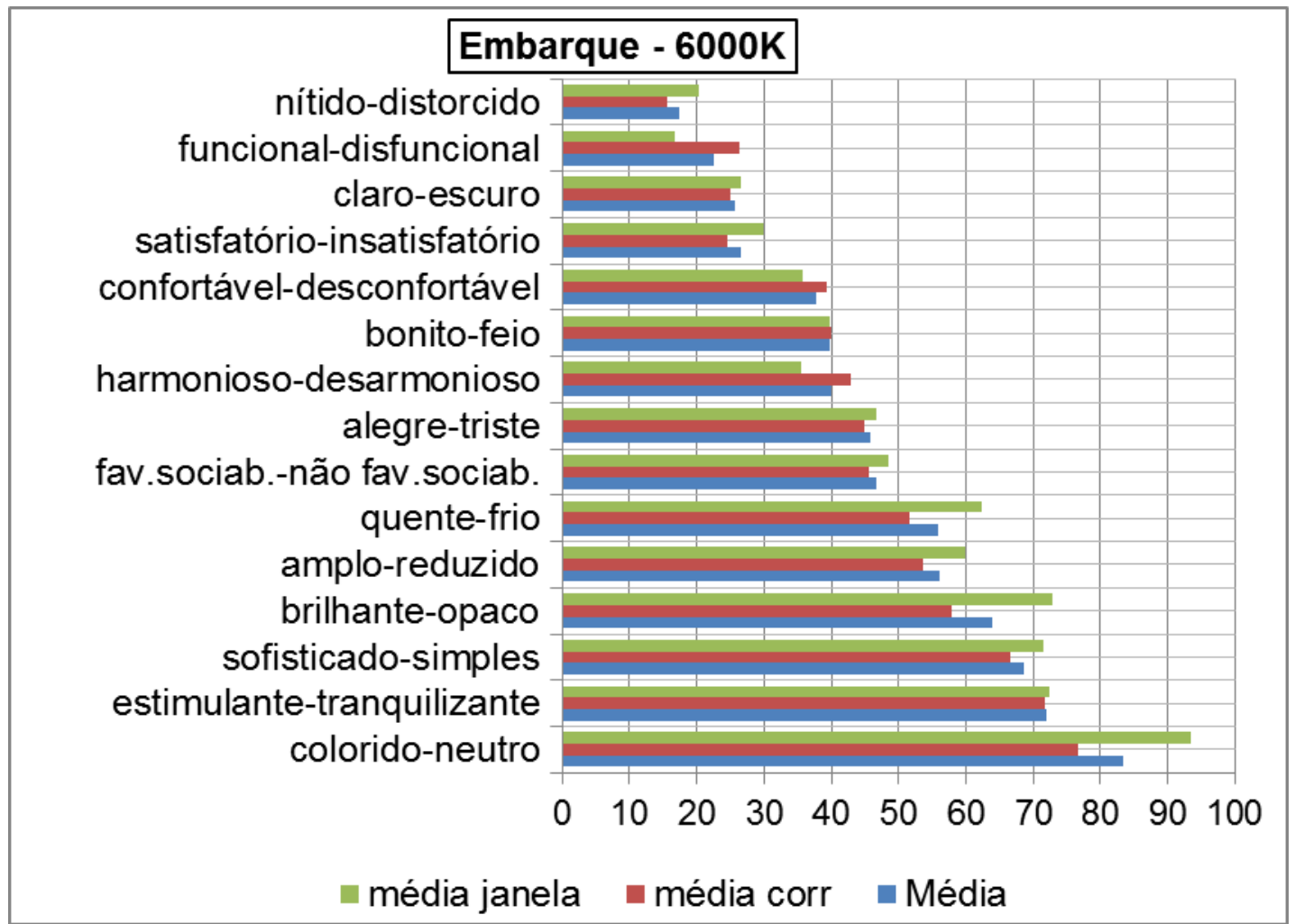

Figura 5.3 Médias obtidas dos diferenciais semânticos para o Embarque cor da iluminação Branco 6000K

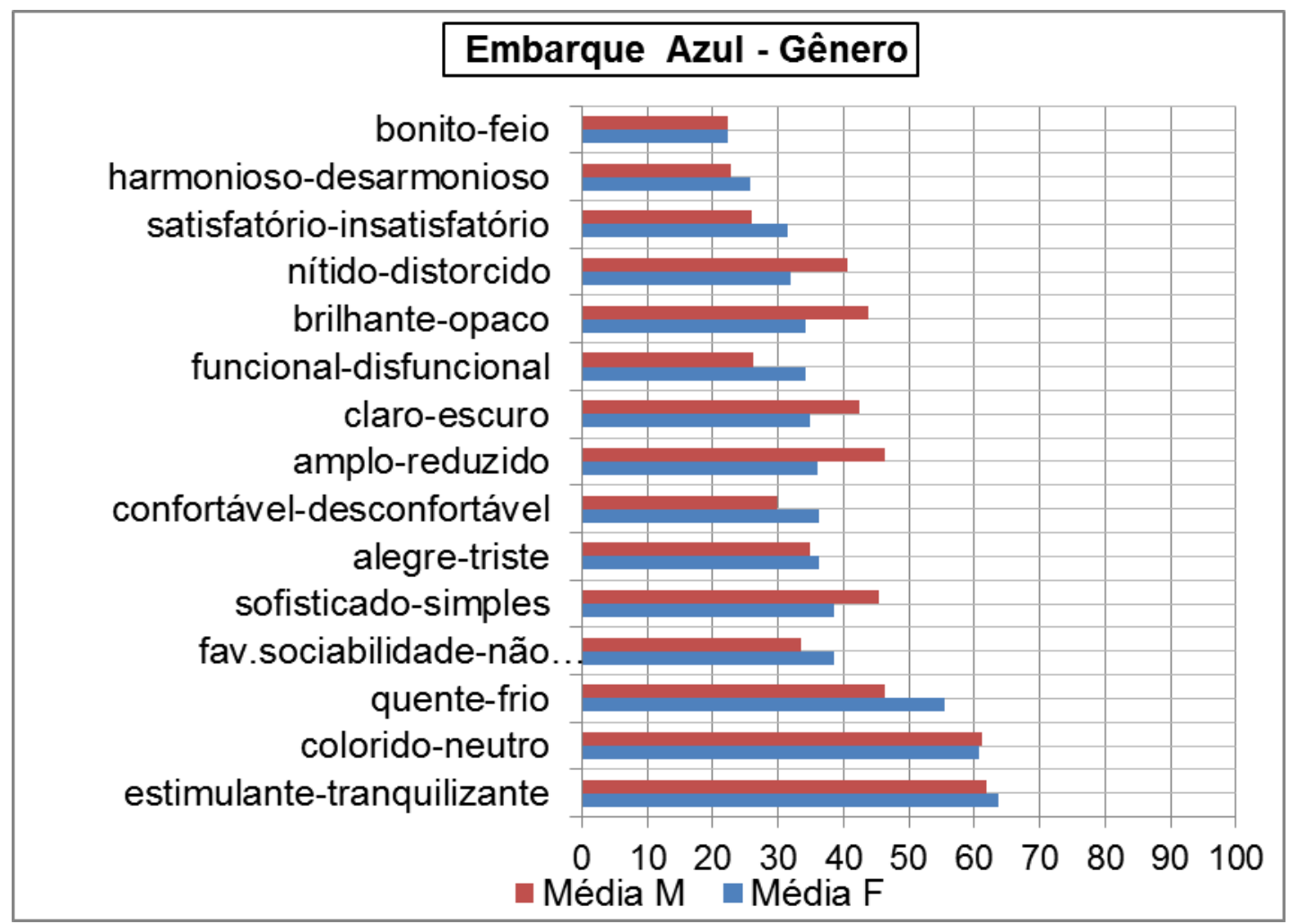

Figura 5.4 Médias obtidas dos diferenciais semânticos para o Embarque cor da iluminação Azul - Gênero 


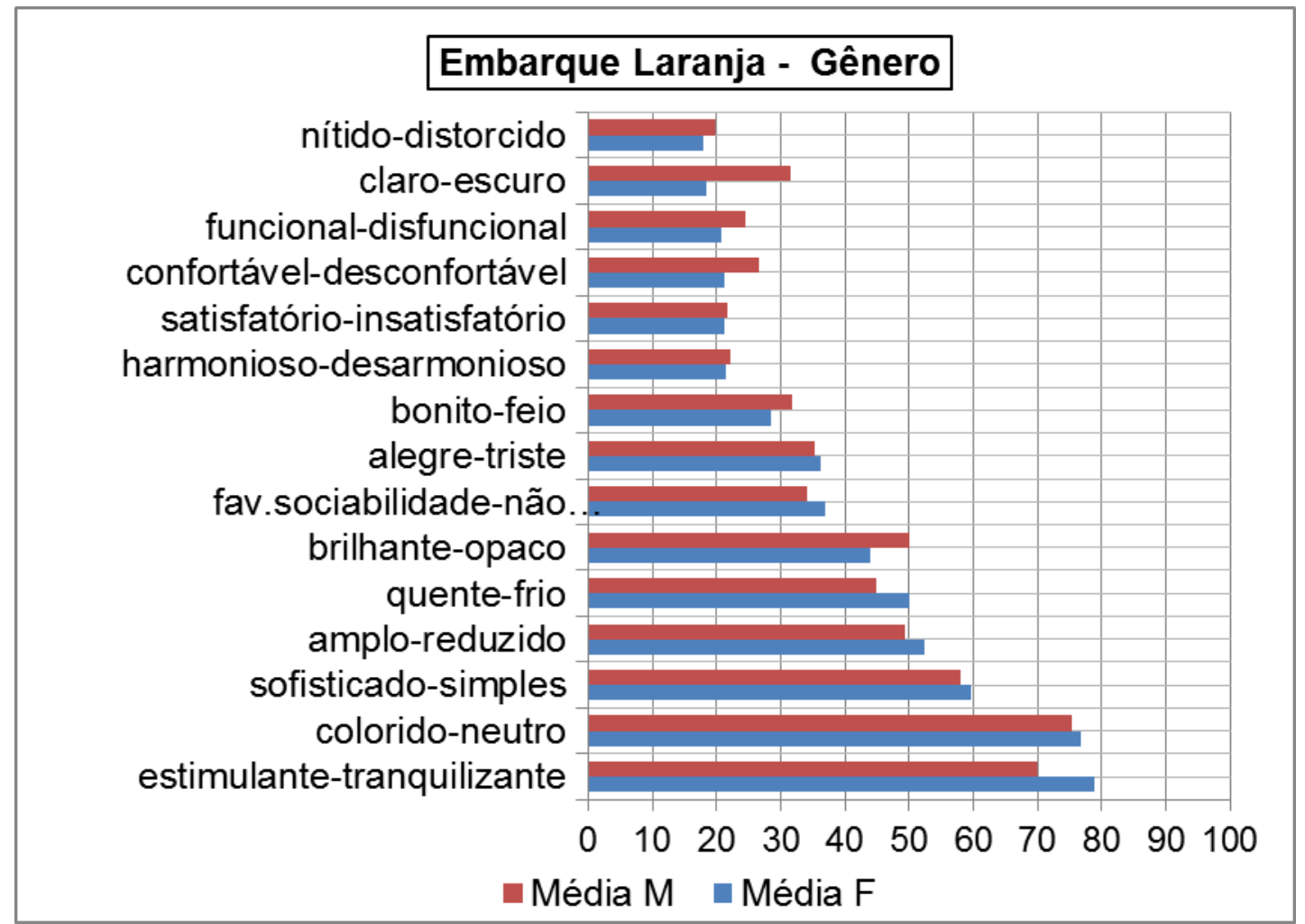

Figura 5.5 Médias obtidas dos diferenciais semânticos para o Embarque cor da iluminação Laranja - Gênero

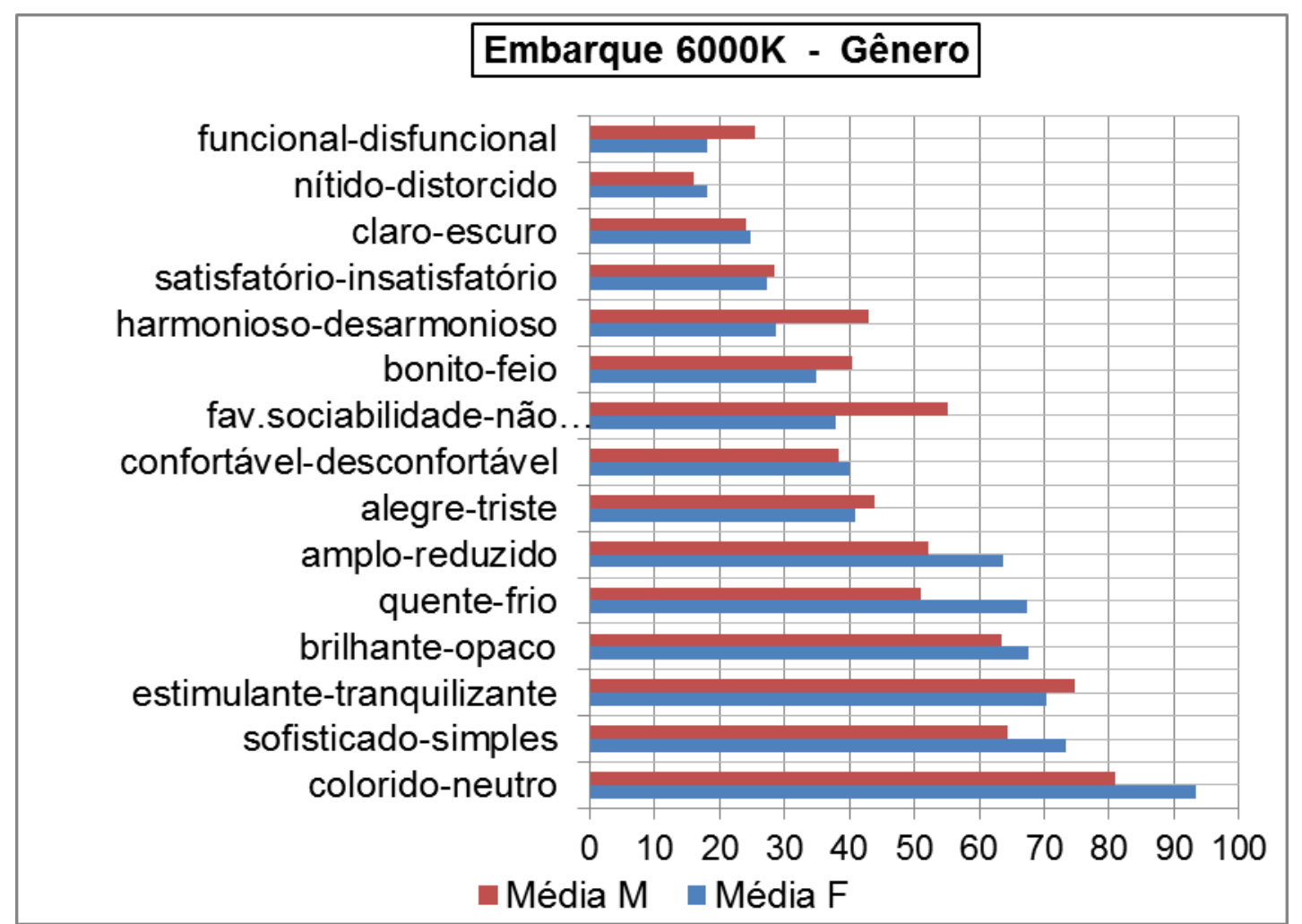

Figura 5.6 Médias obtidas dos diferenciais semânticos para o Embarque cor da iluminação Branco 6000K - Gênero 


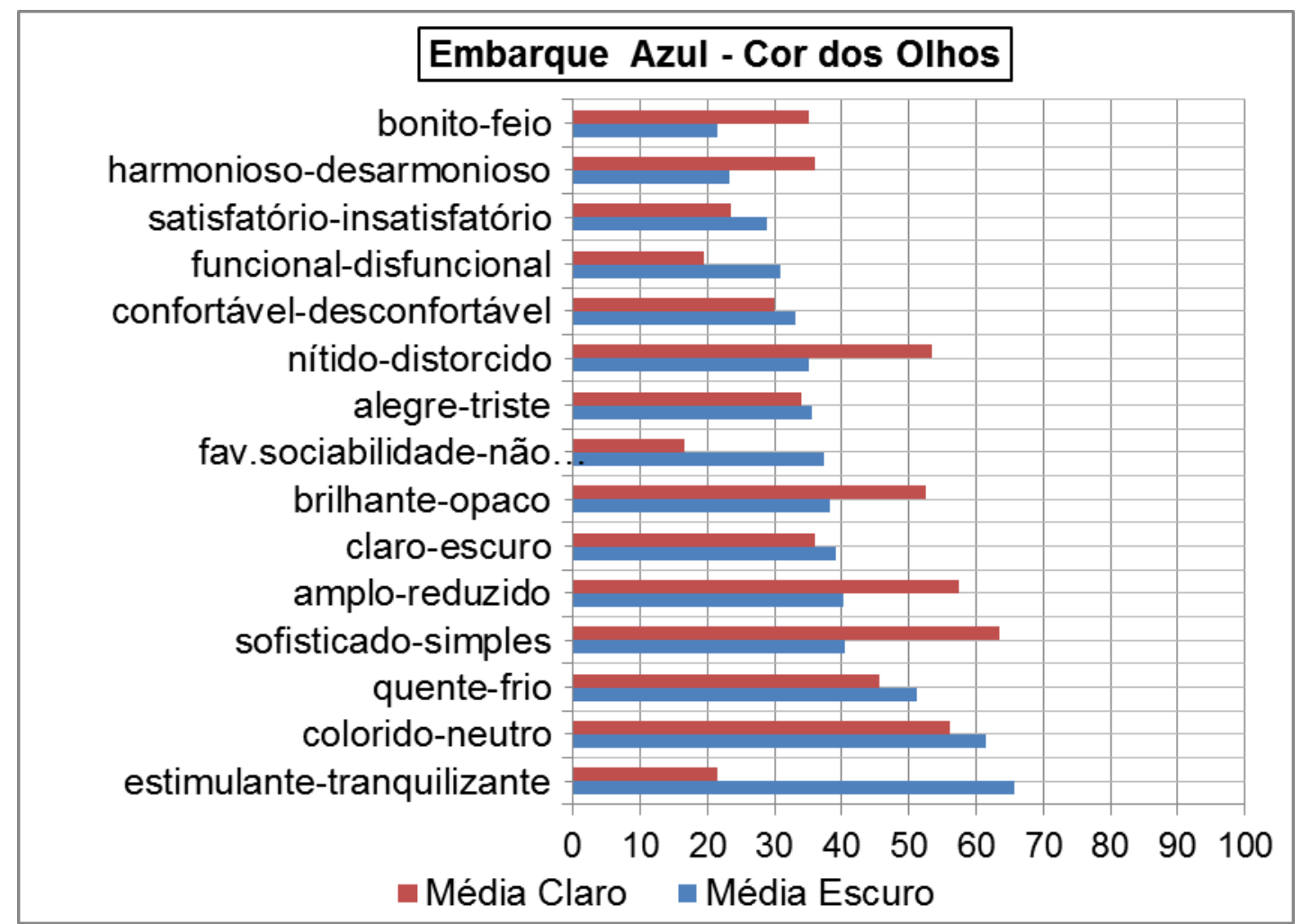

Figura 5.7 Médias obtidas dos diferenciais semânticos para o Embarque cor da iluminação Azul Cor dos Olhos

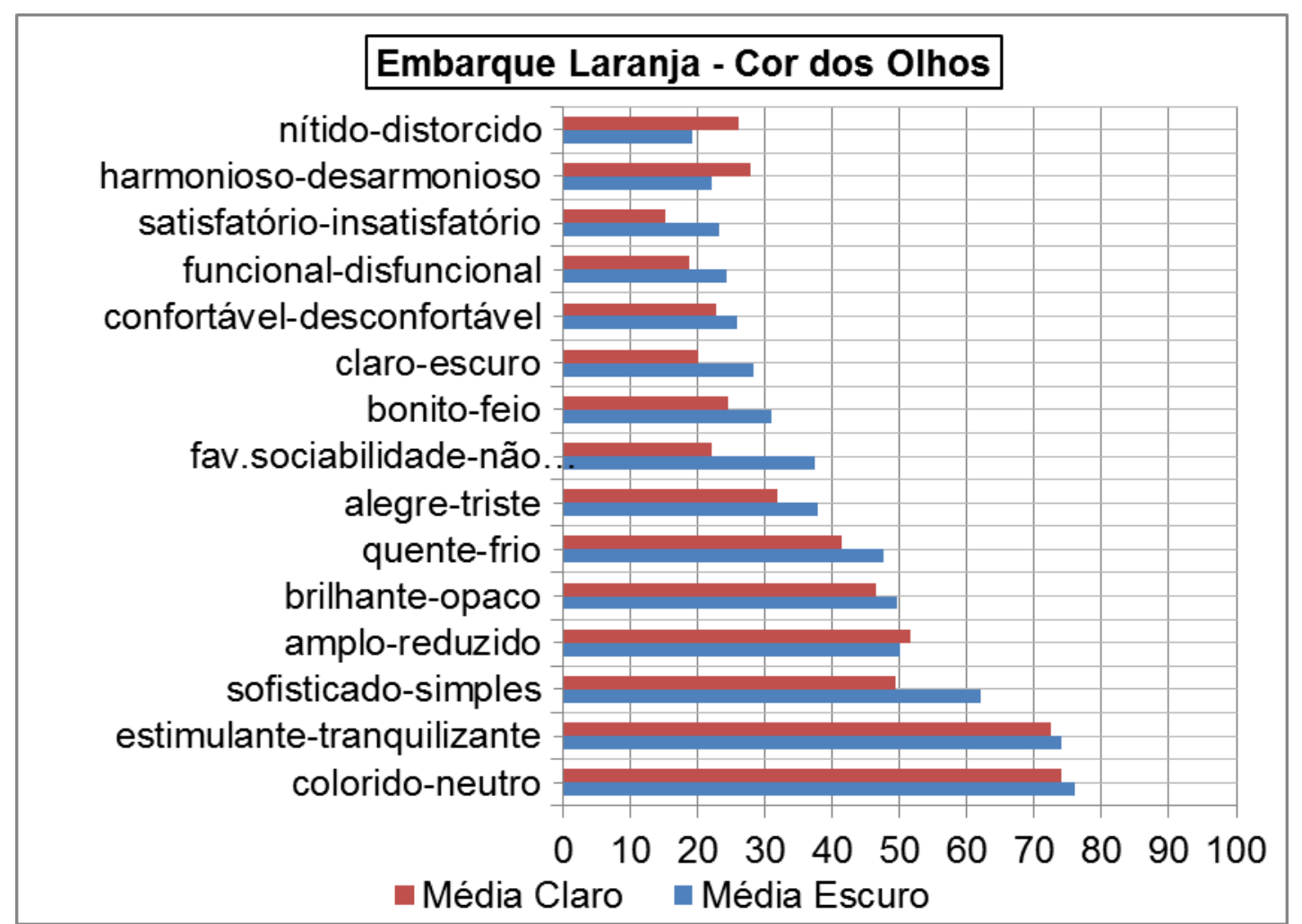

Figura 5.8 Médias obtidas dos diferenciais semânticos para o Embarque cor da iluminação Laranja - Cor dos Olhos 


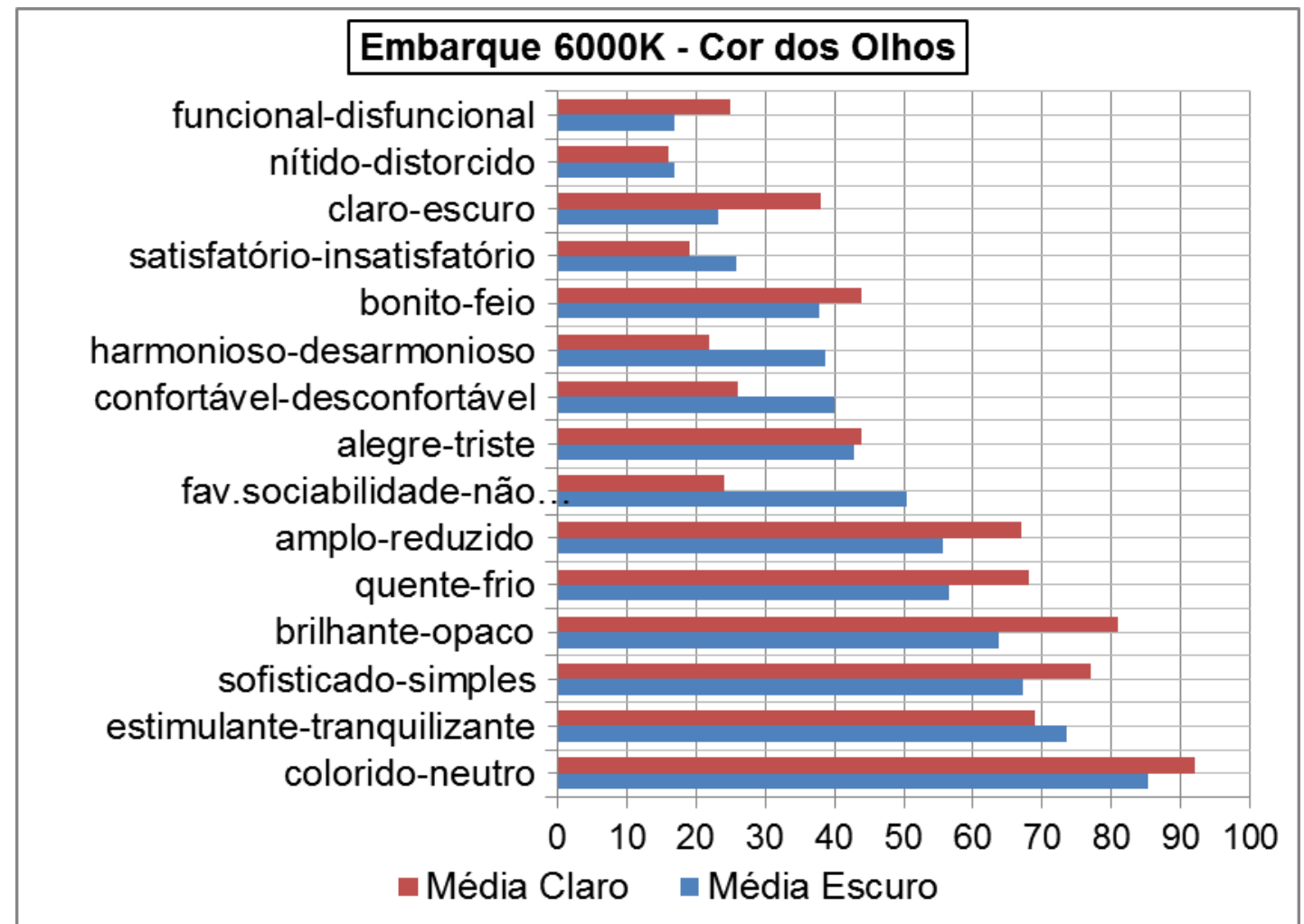

Figura 5.9 Médias obtidas dos diferenciais semânticos para o Embarque cor da iluminação Branco 6000K - Cor dos Olhos

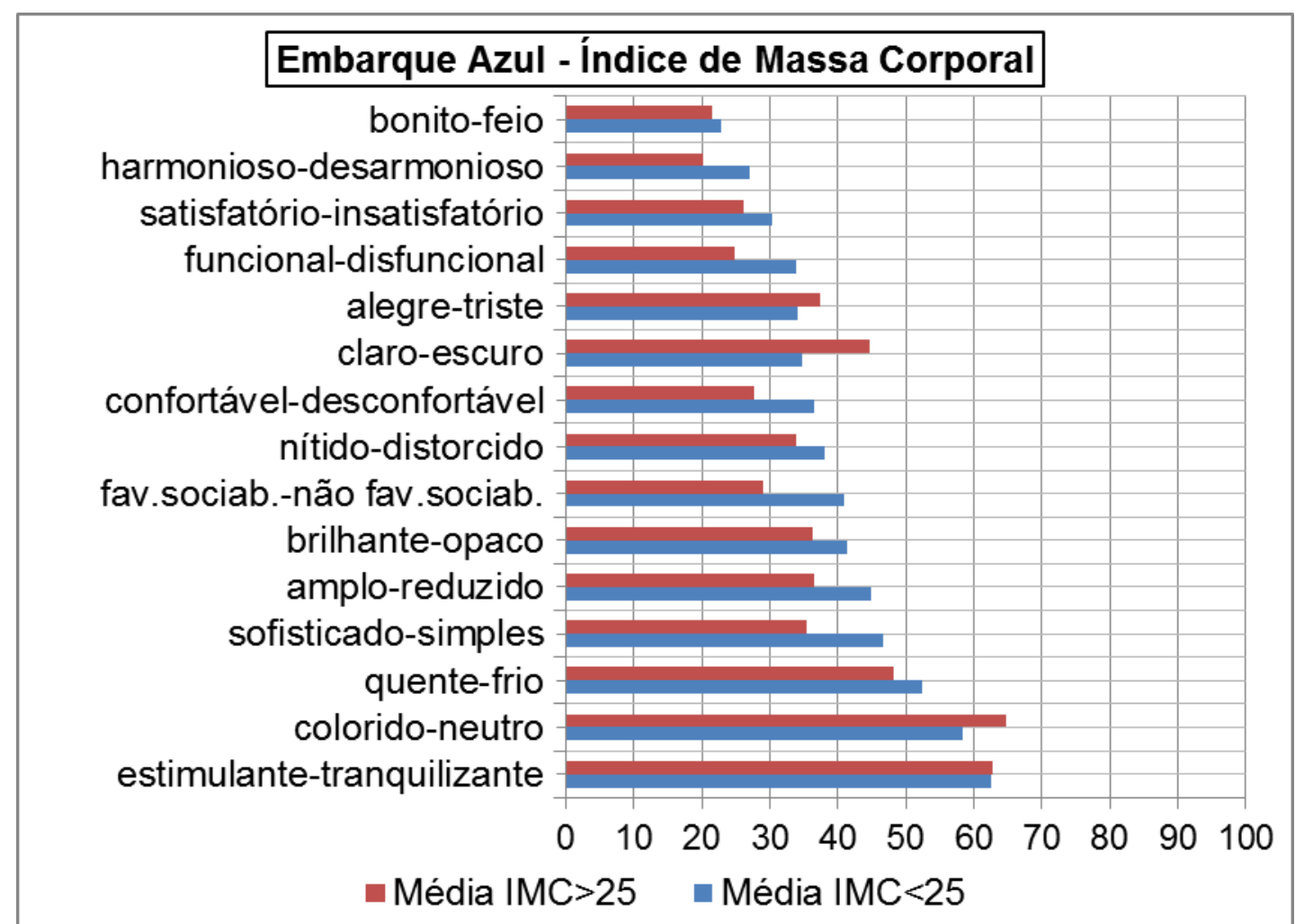

Figura 5.10 Médias obtidas dos diferenciais semânticos para o Embarque cor da iluminação Azul - Indice de Massa Corporal 


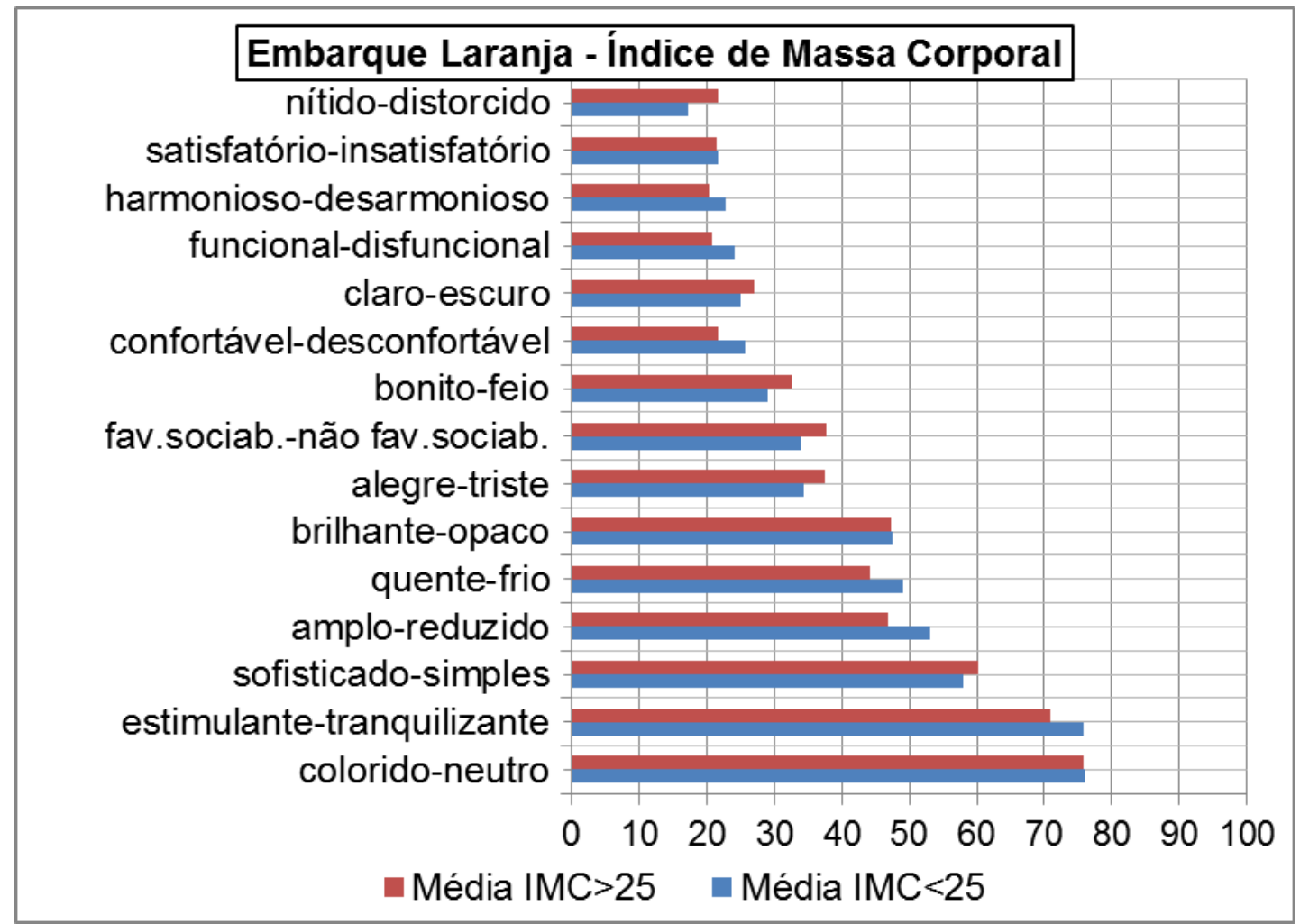

Figura 5.11 Médias obtidas dos diferenciais semânticos para o Embarque cor da iluminação Laranja - Índice de Massa Corporal

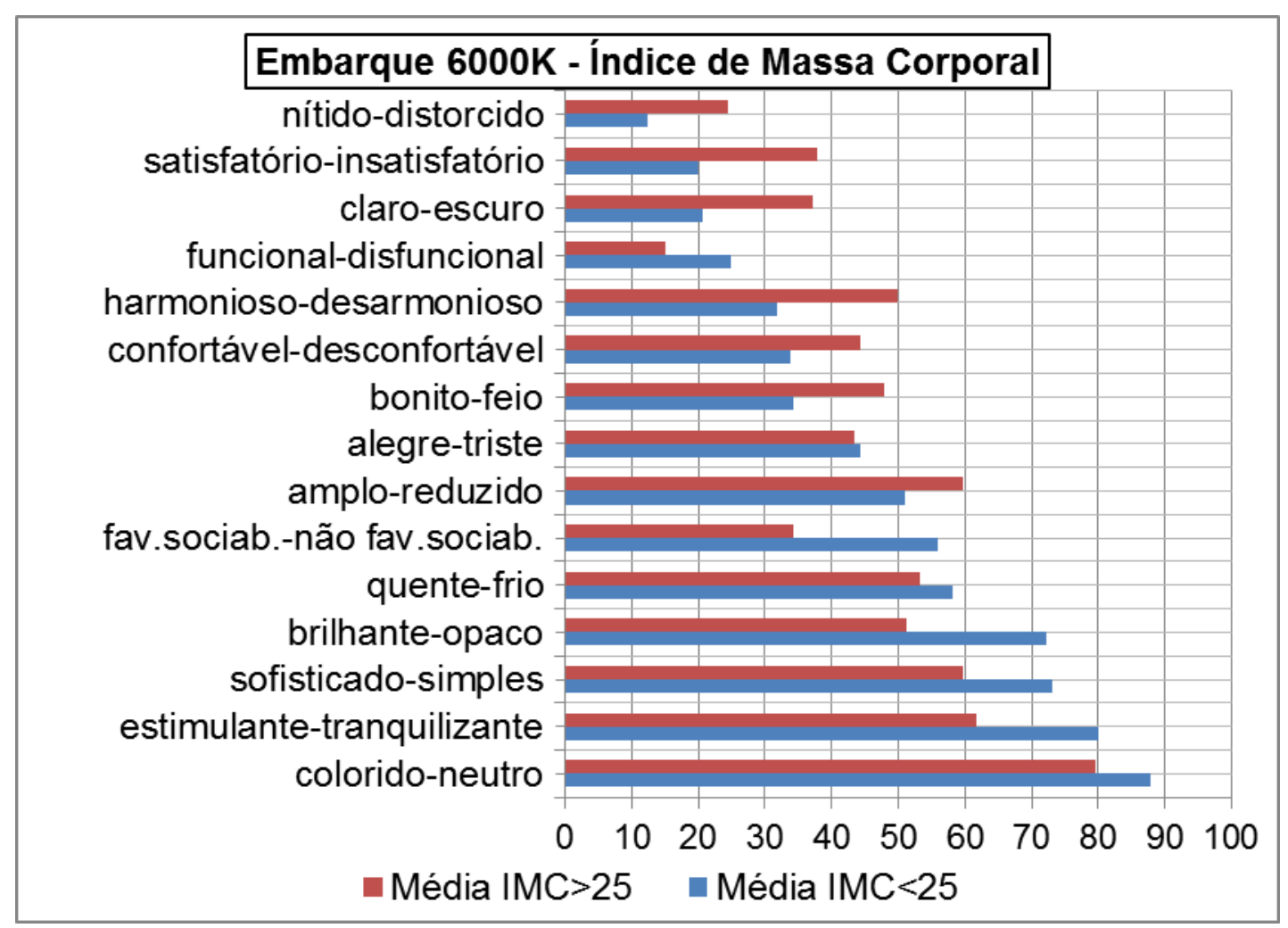

Figura 5.12 Médias obtidas dos diferenciais semânticos para o Embarque cor da iluminação Branco 6000K - Índice de Massa Corporal 


\subsubsection{Cruzeiro 1}

Nessa fase as pessoas estão acomodadas e se adaptando ao ambiente da aeronave. Ainda estão curiosos e apreensivos.

As médias obtidas dos diferenciais semânticos estão mostradas na Figura 5.13 até a Figura 5.24. Nestas figuras o eixo da abcissa representa as médias obtidas em uma escala de valores de 0 a 100 pontos e a ordenada representa os pares de adjetivos. Valores abaixo de 50 pontos são valores mais próximos de adjetivos do lado esquerdo do par de adjetivos e valores acima de 50 pontos são valores mais próximos de adjetivos do lado direito do par de adjetivos.

Tomando-se como base as médias acima de 60 pontos ou abaixo de 40 pontos, os participantes da pesquisa classificaram a iluminação do ambiente, nessa fase do voo, independentemente da cor da iluminação empregada, azul (Figura 5.13) ou laranja (Figura 5.14), como sendo harmonioso/ alegre/ satisfatório/ bonito/ sofisticado/ confortável/ funcional/ brilhante/ nítido/ favorece a sociabilidade/ claro/ amplo.

A luz branca 4000K (Figura 5.15) foi a que apresentou a maior quantidade de adjetivos bipolares do lado esquerdo da Tabela 3.6, ou seja, uma qualificação positiva. Também classifica os pares de adjetivos colorido-neutro/ quente-frio/ estimulantetranquilizante como sendo indiferentes, não havendo tendências para um determinado adjetivo.

As médias dos pontos dos adjetivos bipolares auferidos pelos avaliadores sentados próximo à janela apresentaram valores diferentes em relação as dos avaliadores próximos do corredor, evidenciando a não homogeneidade da iluminação ou a influência de diferenças ergonômicas entre corredor e janela.

Com relação à percepção da cor do ambiente em função das características físicas dos participantes, observa-se que:

a) Quanto ao gênero, quando comparado com a percepção do homem, para a cor azul (Figura 5.16) a mulher considera o ambiente mais brilhante/ claro/ frio do que o homem. Para a cor laranja (Figura 5.17) a mulher percebe o ambiente mais estimulante do que o homem. Para a cor 4000K (Figura 5.18) a mulher considera mais harmonioso/ confortável/ simples/ neutro do que o homem. 
b) Quanto à cor dos olhos, quando comparado com pessoas de olhos claros, para a cor azul (Figura 5.19) as pessoas de olhos escuros consideram o ambiente mais alegre/ feio/ brilhante/ frio/ neutro do que as de olhos claros. Para a cor laranja (Figura 5.20), as pessoas de olhos escuros percebem o ambiente mais insatisfatório/ desconfortável/ não favorece a sociabilidade/ reduzido/ simples/ neutro do que as de olhos claros. Para a cor branco 4000K (Figura 5.21), pessoas de olhos escuros percebem o ambiente como sendo mais distorcido/ insatisfatório/ disfuncional/ desarmonioso/ desconfortável/ triste/ não favorece a sociabilidade/ amplo/ brilhante/ sofisticado/ estimulante/ colorido do que as de olhos claros.

Observa-se que há diferenças acentuadas para a percepção da qualidade do ambiente, em função da iluminação, para a característica da cor dos olhos, sugerindo certo grau de importância a consideração deste fator na escolha da cor da iluminação de um ambiente. A cor dos olhos é um fator importante na determinação do padrão de iluminação da cabine.

Com relação ao índice de massa corporal, não se observou diferenças nas avalições da qualidade do ambiente para as cores de iluminação azul (Figura 5.22) e laranja (Figura 5.23). Para a cor branco 4000K (Figura 5.24), pessoas com IMC $>25$, comparando-se com pessoas com $\mathrm{IMC}<25$, consideraram 0 ambiente mais insatisfatório/ distorcido/ disfuncional/ escuro/ desarmonioso/ desconfortável/ feio/ favorece a sociabilidade/ brilhante/ sofisticado/ estimulante. 


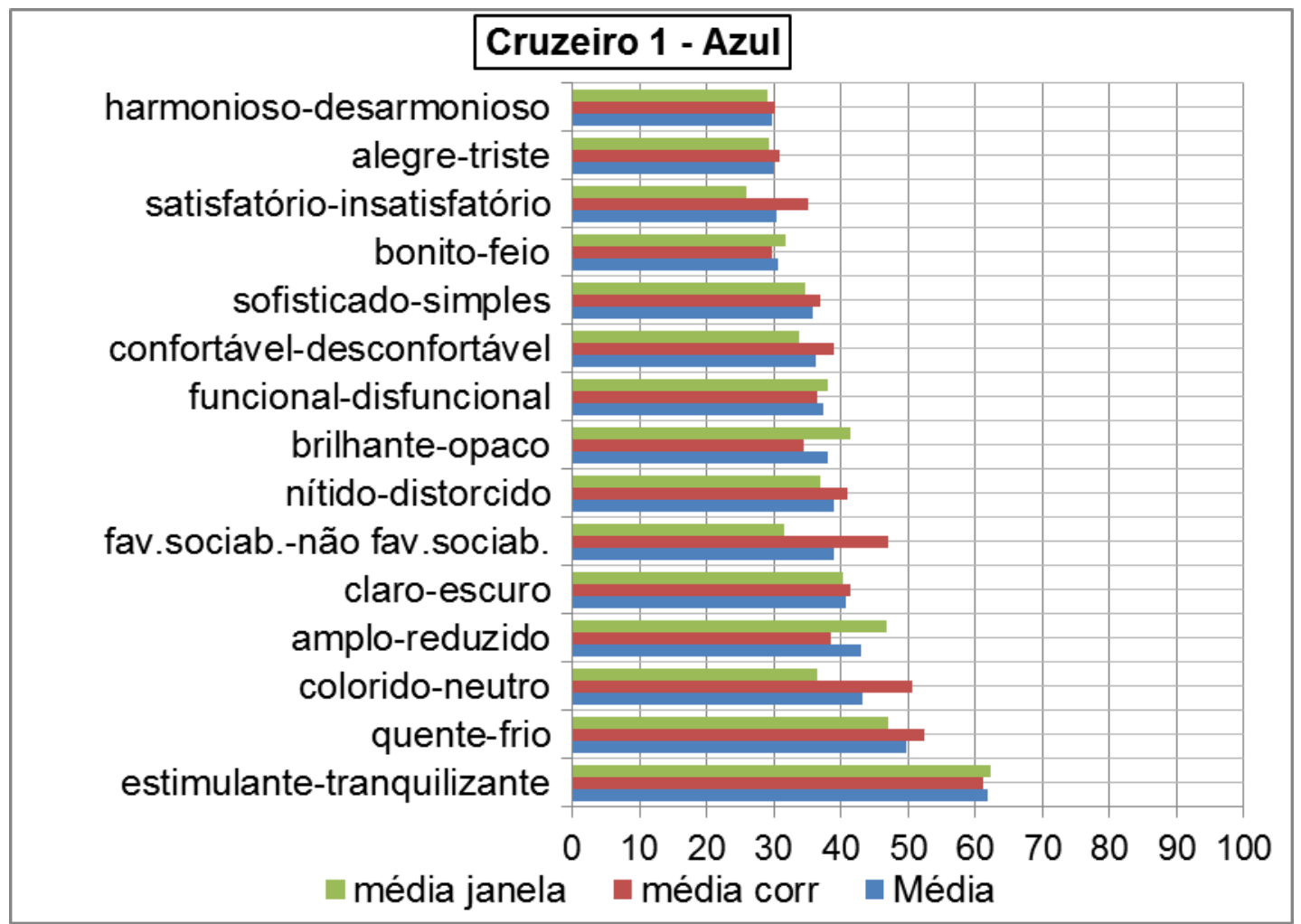

Figura 5.13 Médias obtidas dos diferenciais semânticos para o Cruzeiro 1 cor da iluminação Azul

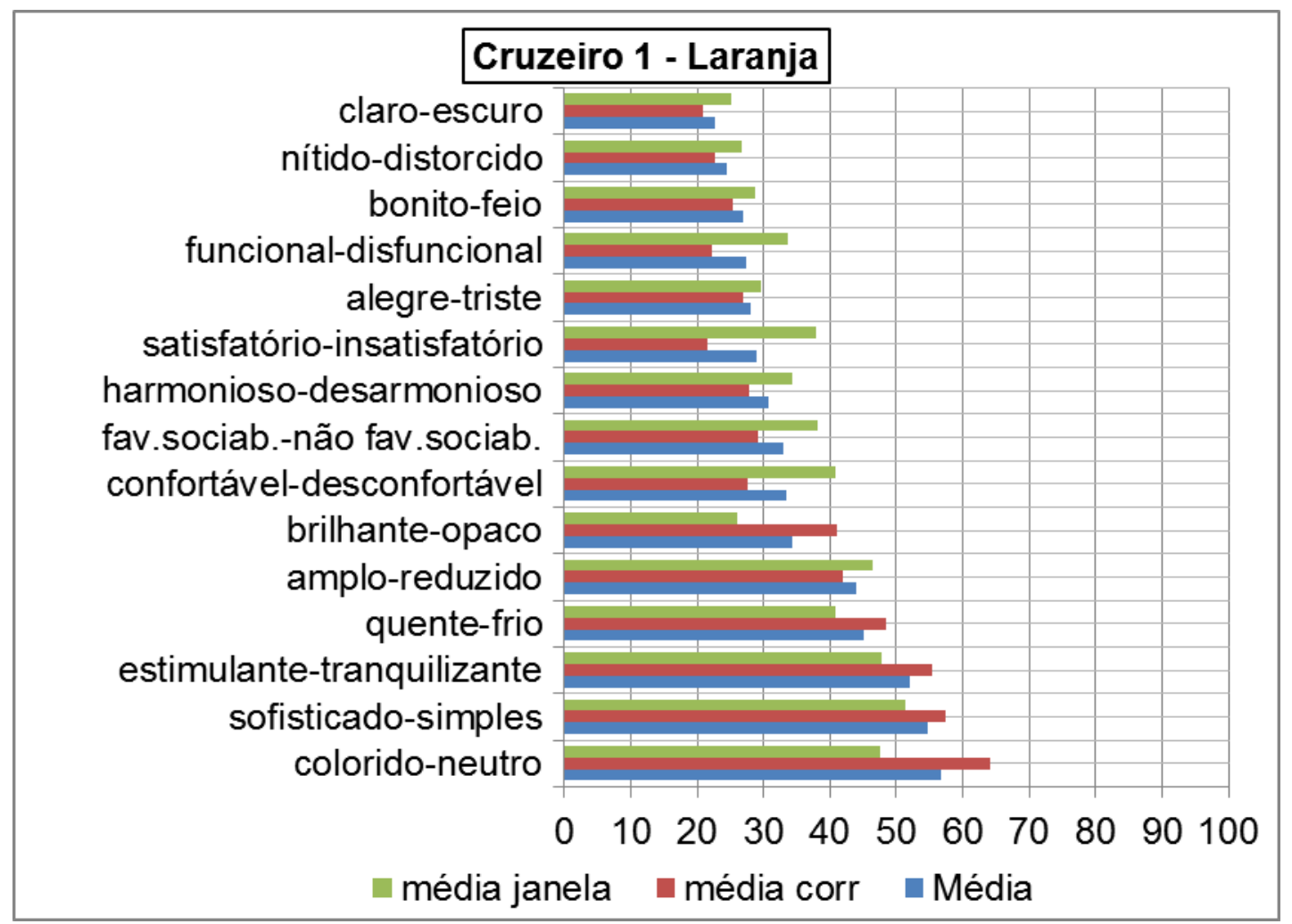

Figura 5.14 Médias obtidas dos diferenciais semânticos para o Cruzeiro 1 cor da iluminação Laranja 


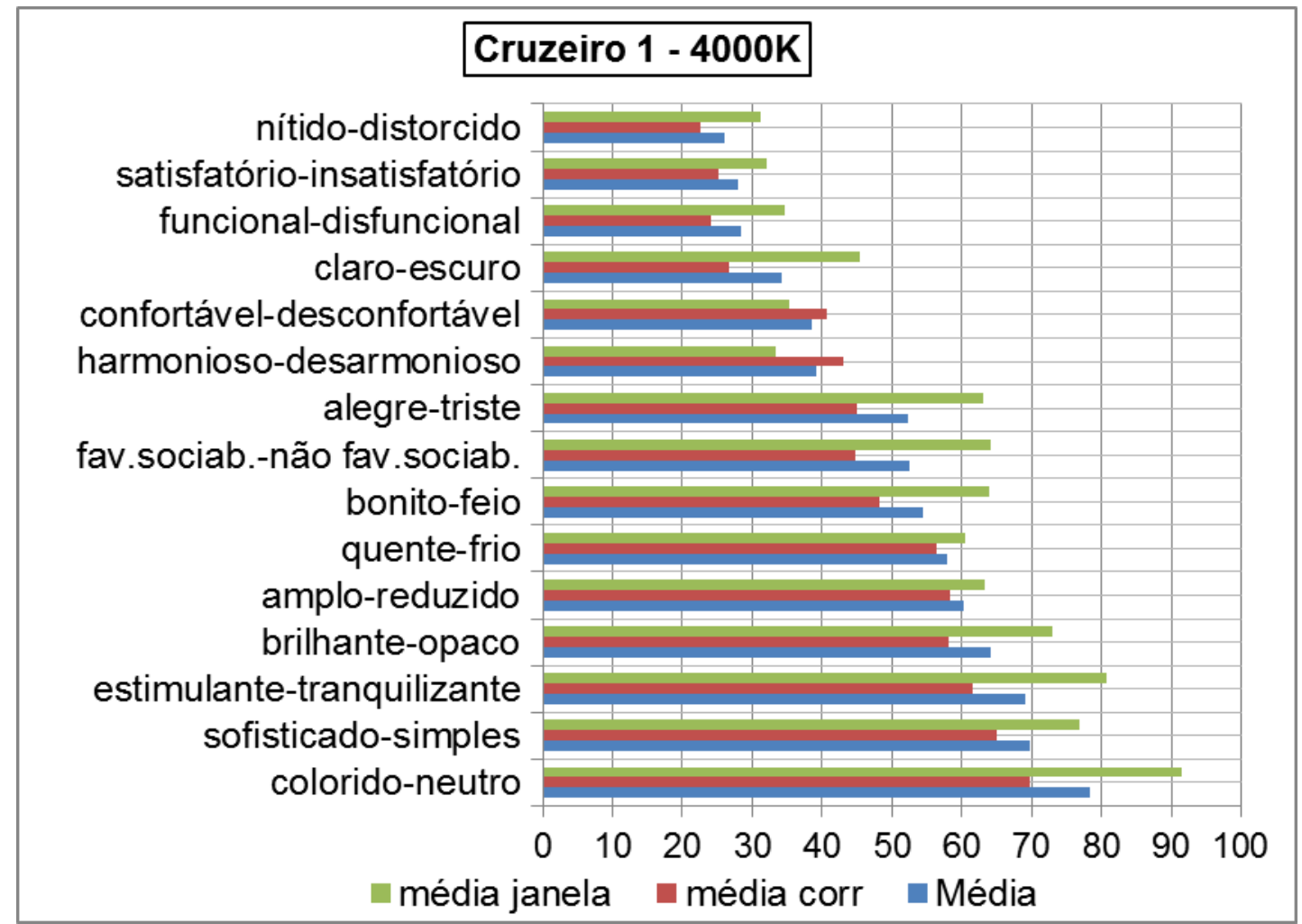

Figura 5.15 Médias obtidas dos diferenciais semânticos para o Cruzeiro 1 cor da iluminação $4000 \mathrm{~K}$

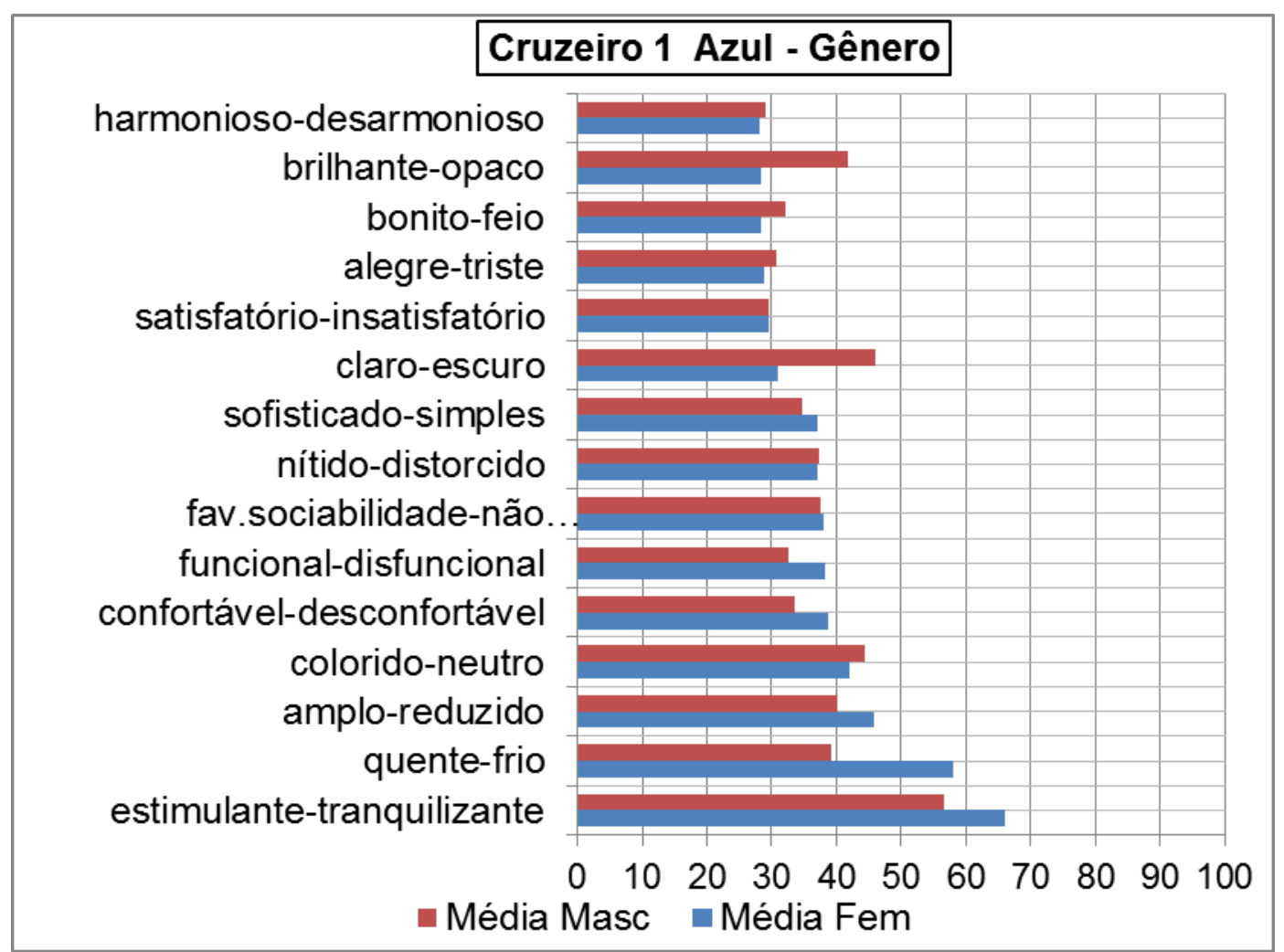

Figura 5.16 Médias obtidas dos diferenciais semânticos para o Cruzeiro 1 cor da iluminação Azul - Gênero 


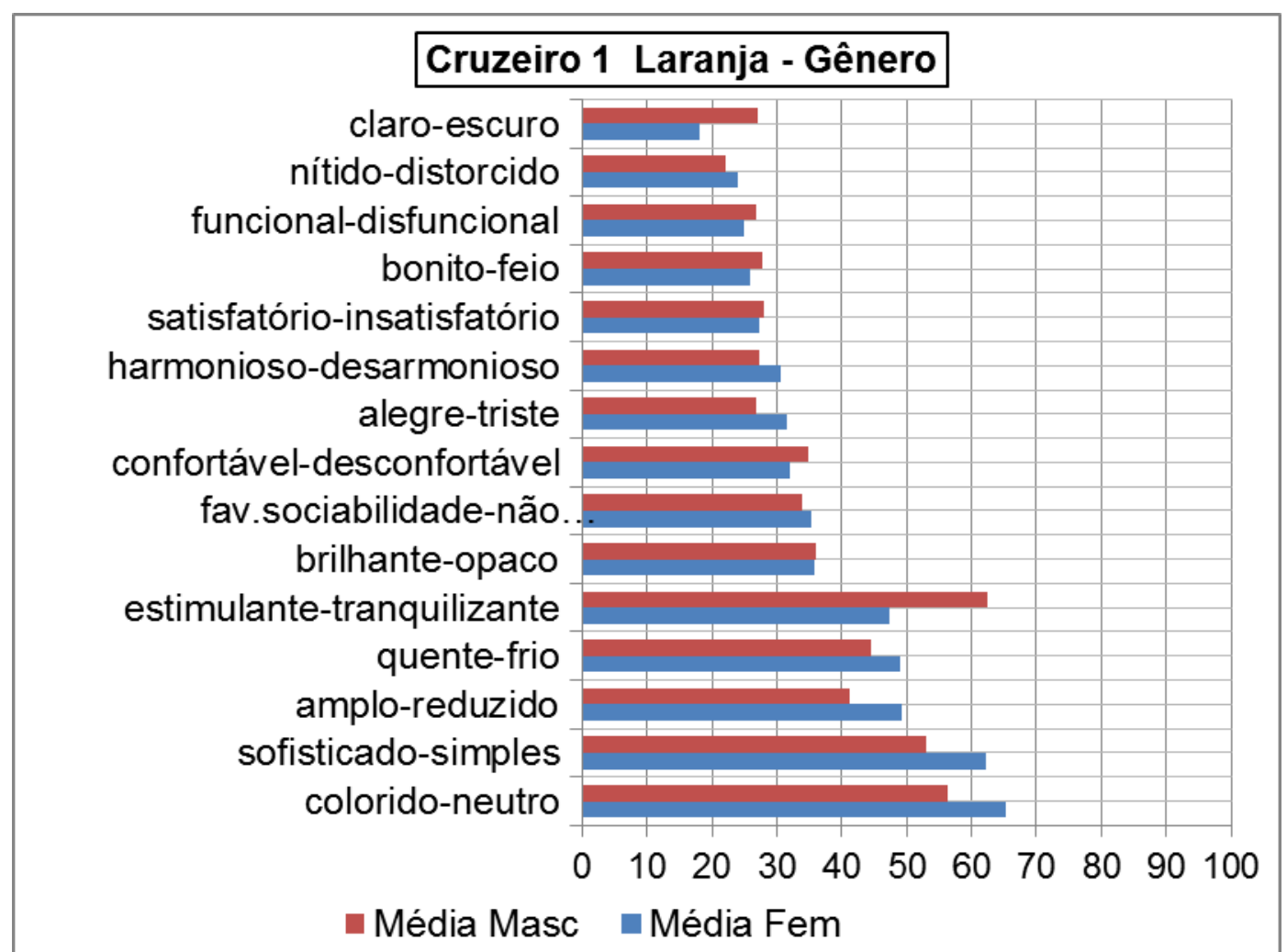

Figura 5.17 Médias obtidas dos diferenciais semânticos para o Cruzeiro 1 cor da iluminação Laranja - Gênero

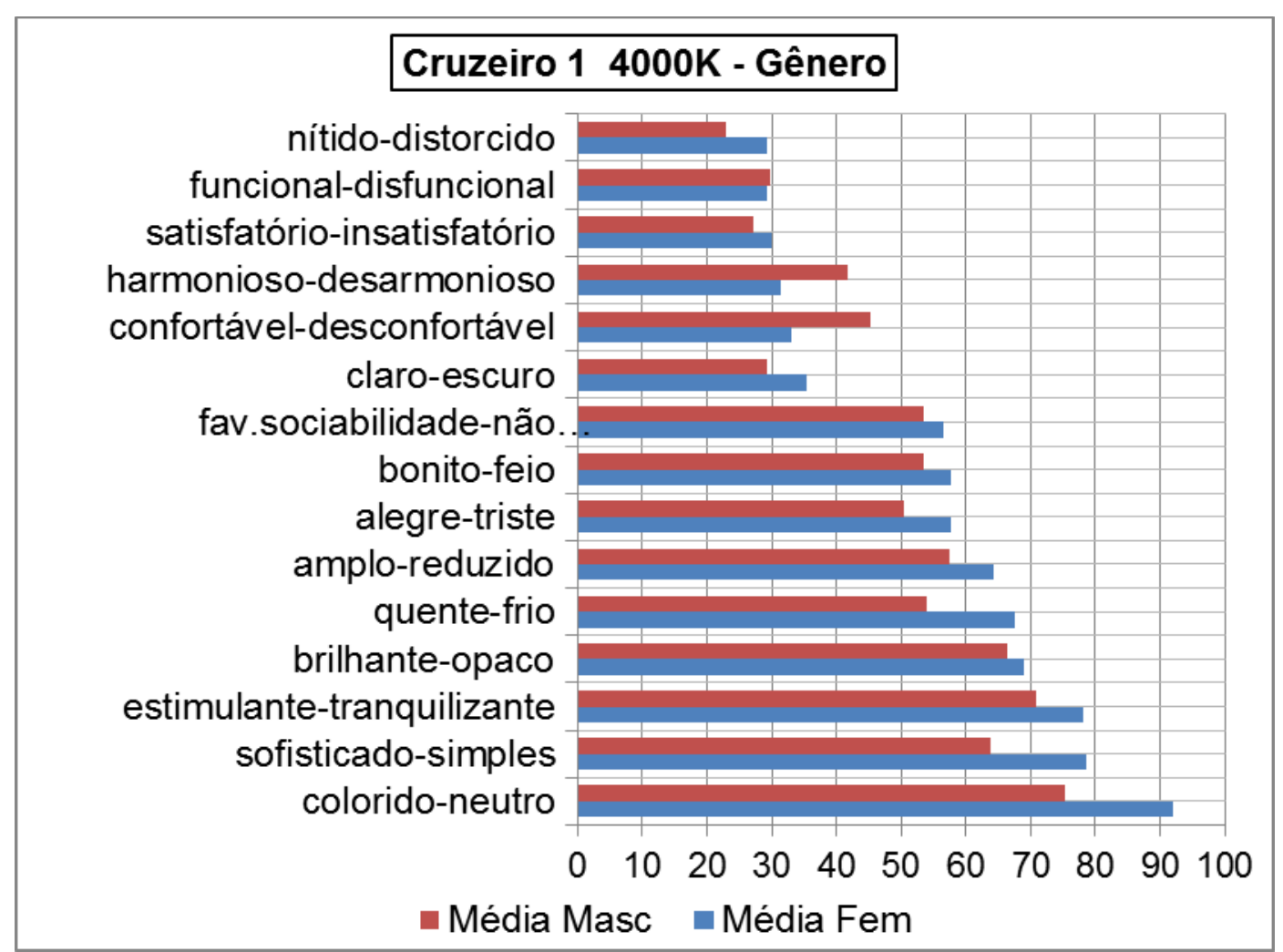

Figura 5.18 Médias obtidas dos diferenciais semânticos para o Cruzeiro 1 cor da iluminação Branco 4000K - Gênero 


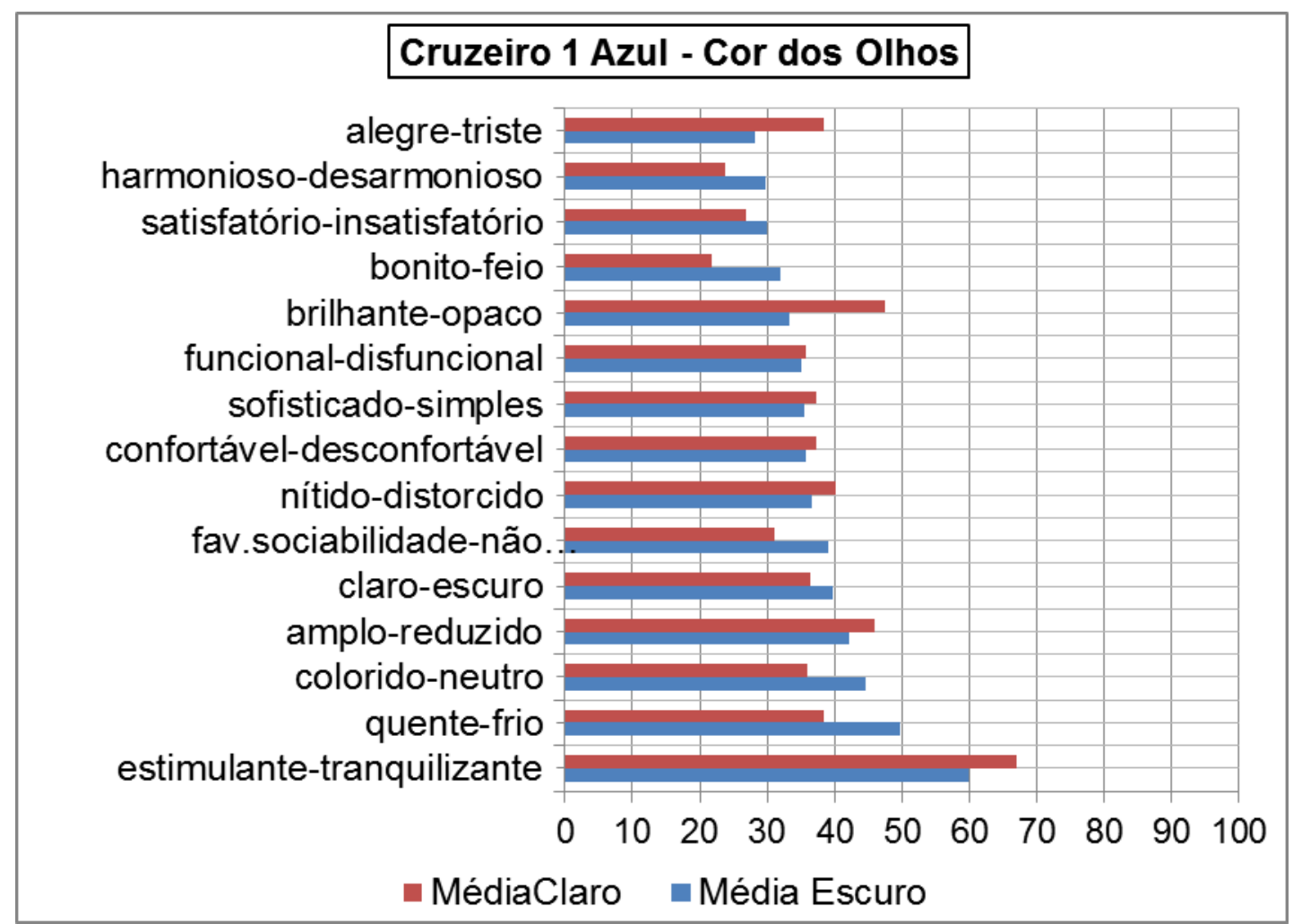

Figura 5.19 Médias obtidas dos diferenciais semânticos para o Cruzeiro 1 cor da iluminação Azul - Cor dos Olhos

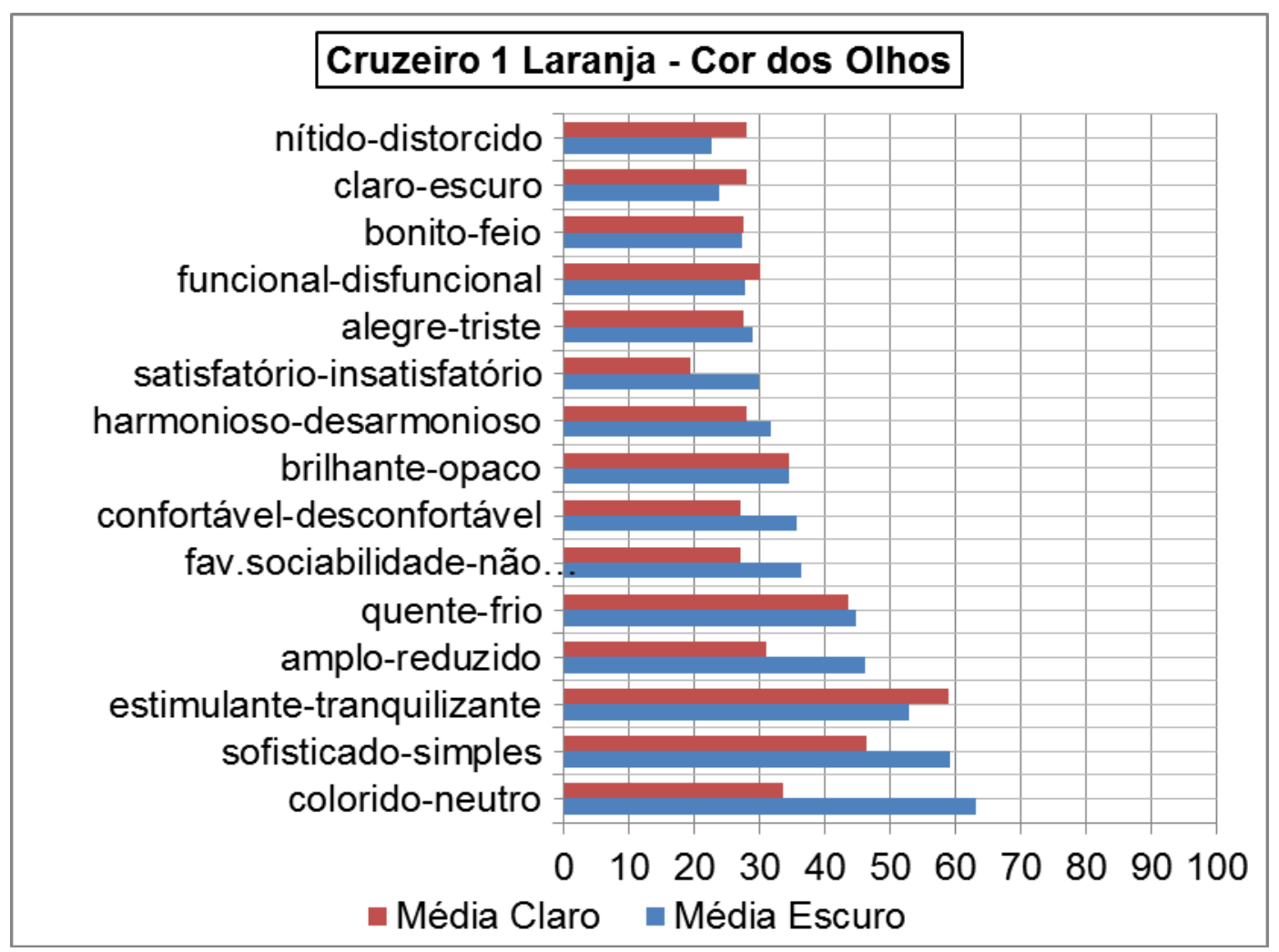

Figura 5.20 Médias obtidas dos diferenciais semânticos para o Cruzeiro 1 cor da iluminação Laranja - Cor dos Olhos 


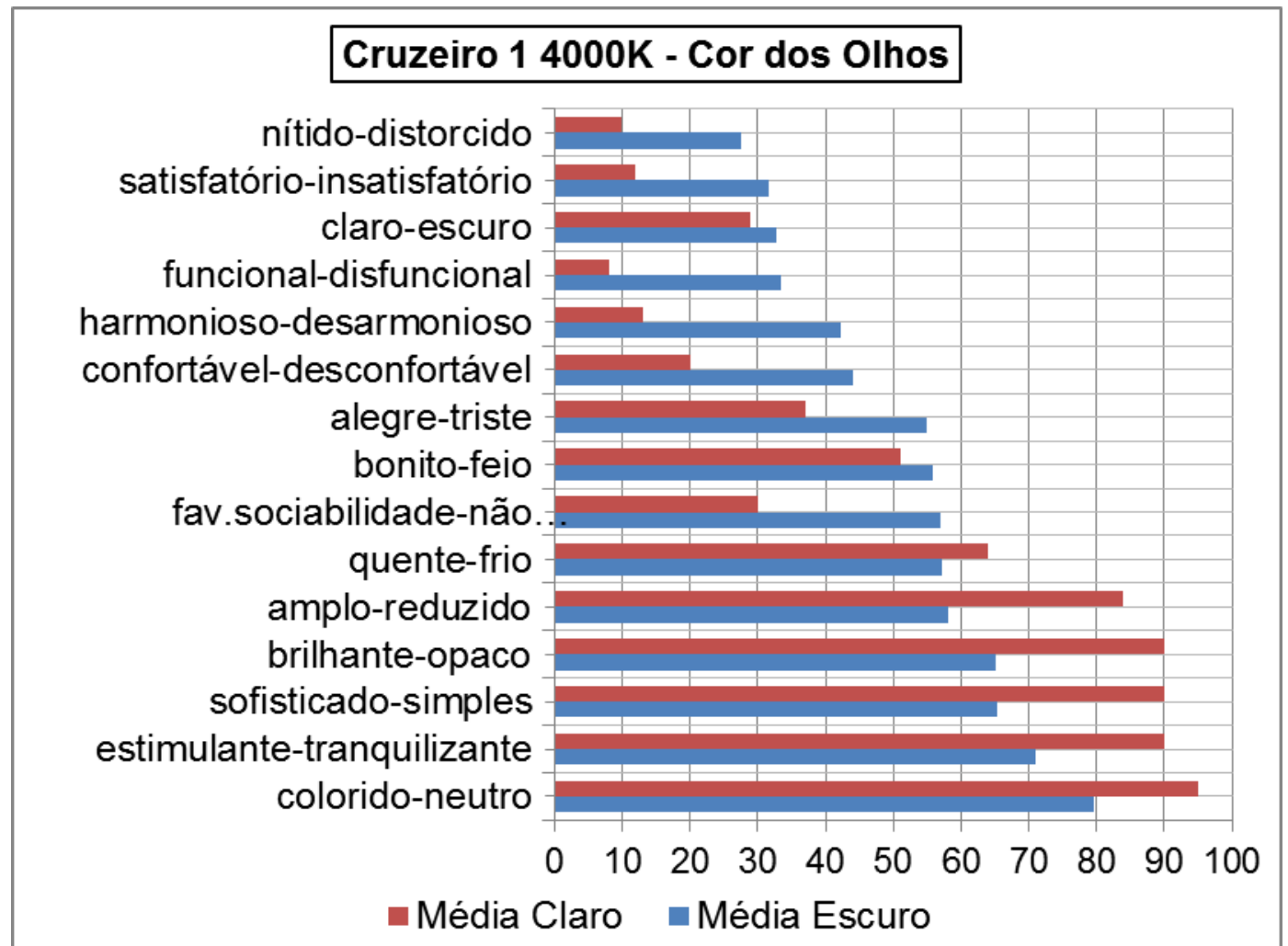

Figura 5.21 Médias obtidas dos diferenciais semânticos para o Cruzeiro 1 cor da iluminação Branco 4000K - Cor dos Olhos

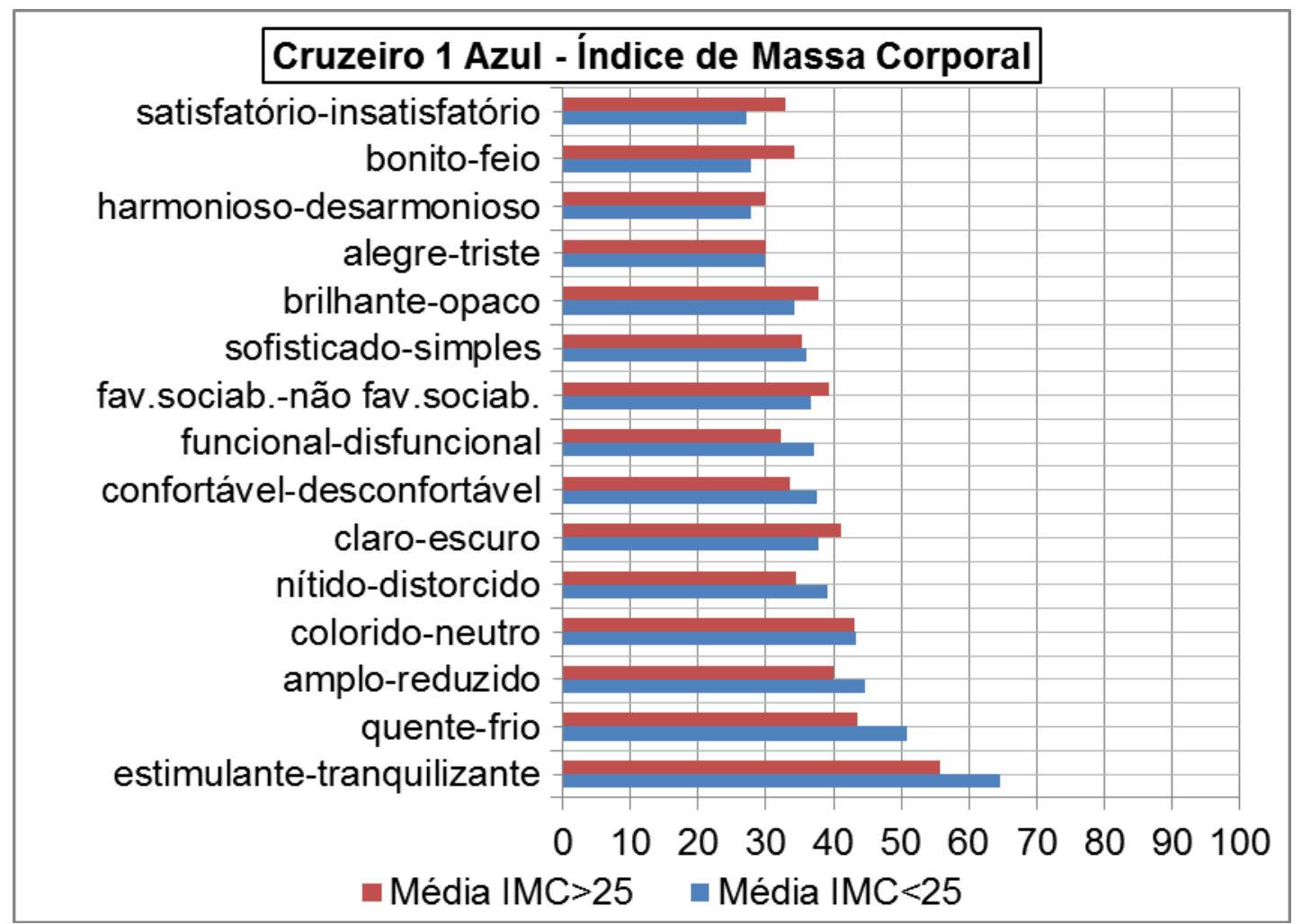

Figura 5.22 Médias obtidas dos diferenciais semânticos para o Cruzeiro 1 cor da iluminação Azul - Indice de Massa Corporal 


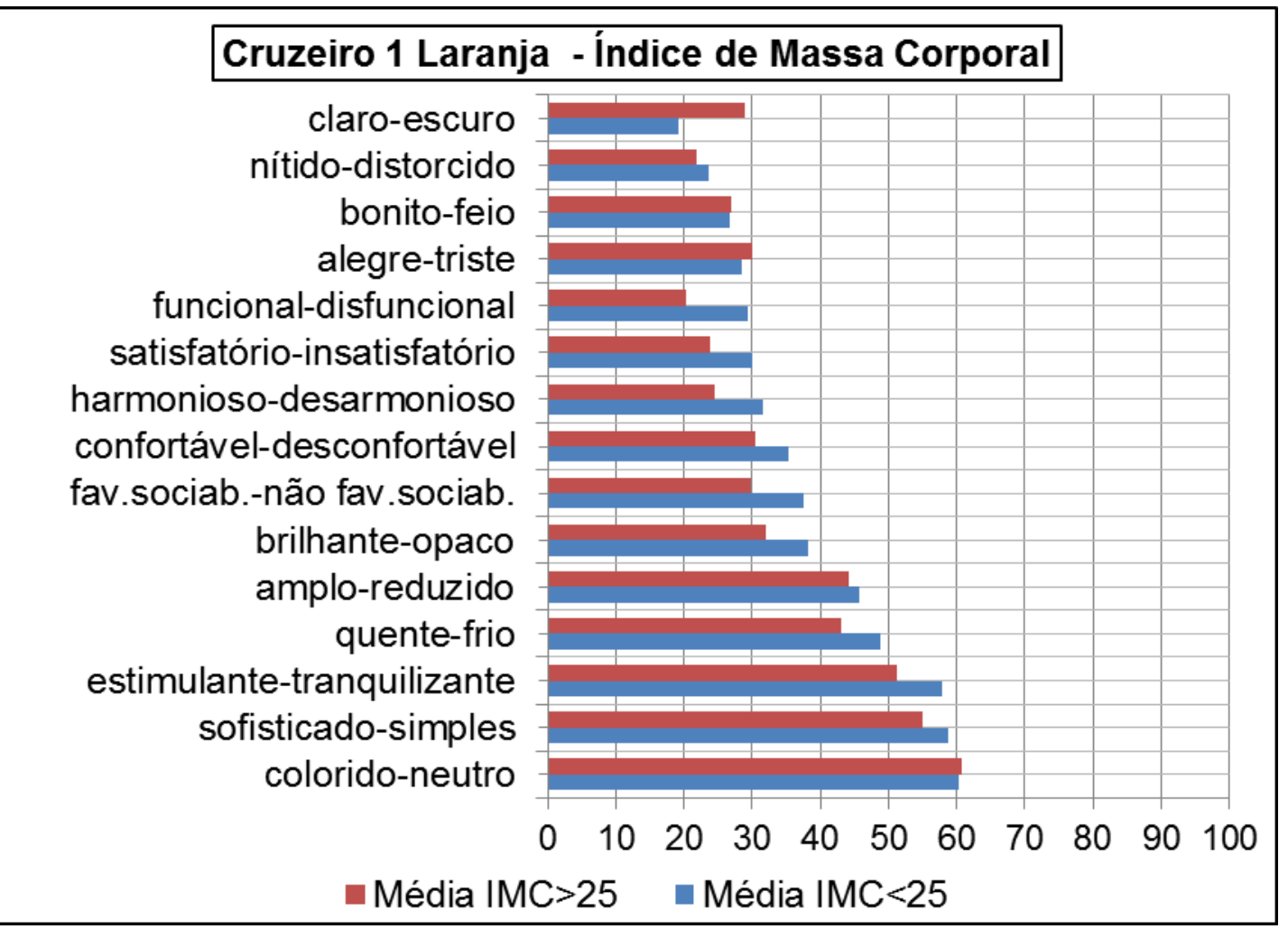

Figura 5.23 Médias obtidas dos diferenciais semânticos para o Cruzeiro 1 cor da iluminação Laranja - Índice de Massa Corporal

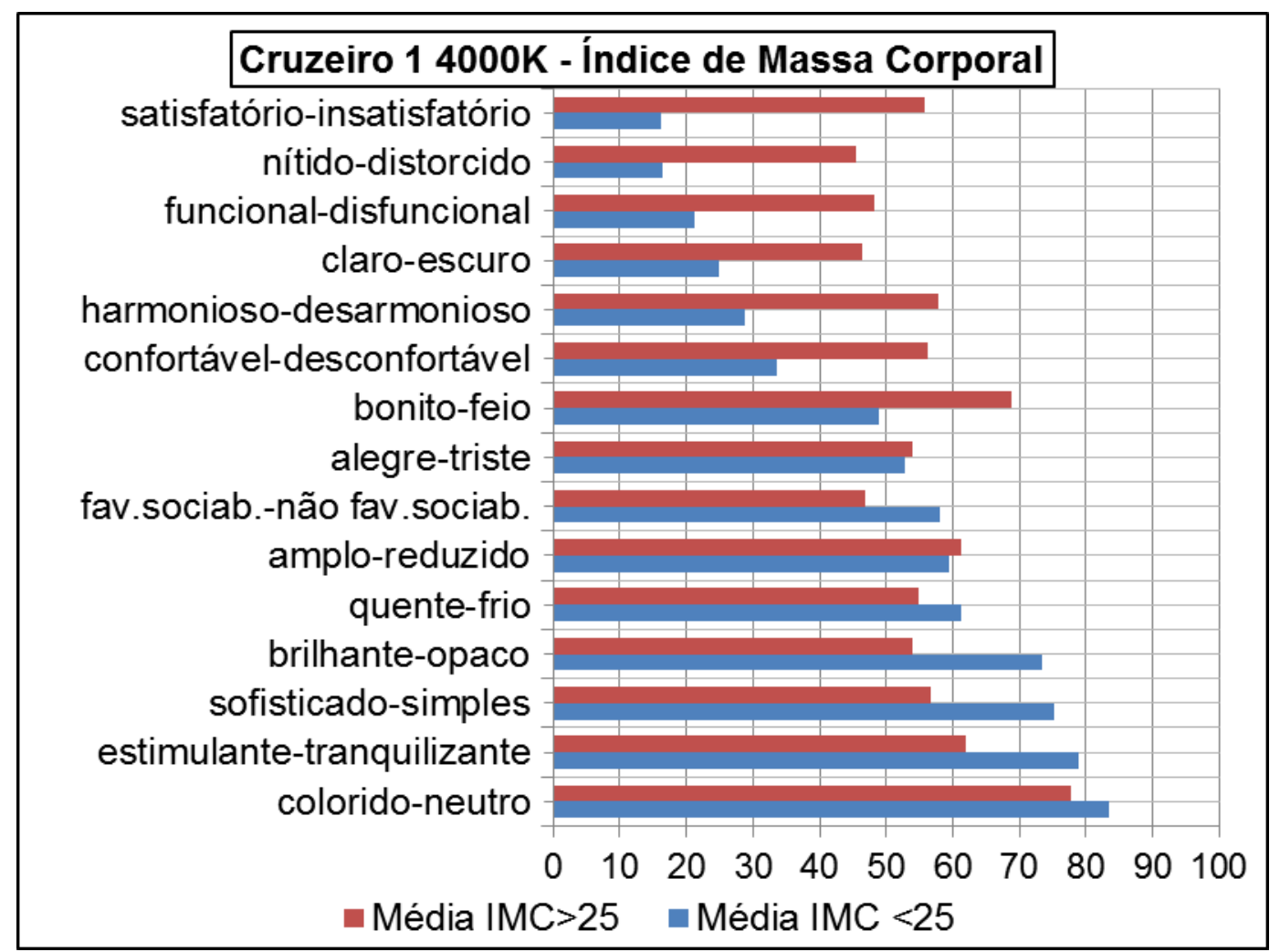

Figura 5.24 Médias obtidas dos diferenciais semânticos para o Cruzeiro 1 cor da iluminação Branco 4000K - Índice de Massa Corporal 


\subsubsection{Serviço de Bordo}

Nessa fase é servido lanche com bebida.

As médias obtidas dos diferenciais semânticos estão mostradas da Figura 5.25 até a Figura 5.32. Nestas figuras o eixo da abcissa representa as médias obtidas considerando valores de 0 a 100 pontos e a ordenada representa os pares de adjetivos. Valores abaixo de 50 pontos são valores mais próximos de adjetivos do lado esquerdo do par de adjetivos e valores acima de 50 pontos são valores mais próximos de adjetivos do lado direito do par de adjetivos.

Para a cor de iluminação laranja (Figura 5.25), praticamente todas as pontuações ficaram abaixo de 40 pontos, qualificando essa iluminação muito adequada.

Para a cor de iluminação branco 3000K (Figura 5.26), as médias obtidas foram superiores às da cor de iluminação laranja, e considerando pontuações maiores do que 60 pontoas e menores do que 40pontos, os avaliadores consideraram o ambiente como sendo nítido/ satisfatório/ funcional/ claro/ harmonioso/ confortável/ bonito/ alegre/ frio/ opaco/ simples/ neutro.

Também nessa fase foram encontradas diferenças significativas das avaliações entre pessoas sentadas no corredor e na janela, evidenciando a não uniformidade da iluminação ou diferenças ergonômicas.

Com a Luz "Branco 3000K", a maior parte das pessoas sentadas no corredor pontuaram os pares de adjetivos com valores menores do que as pessoas sentadas na janela, caracterizando que para as pessoas sentadas no corredor a iluminação é mais adequada em relação às pessoas sentadas na janela.

De maneira geral a cor da iluminação laranja é mais adequada do que a cor da iluminação branco 3000K.

Com relação à influência das características físicas dos avaliadores nos resultado da percepção da cor do ambiente observa-se que quanto ao gênero há igualdade na avaliação na cor Laranja (Figura 5.27), porém para a cor branco 3000K (Figura 5.28) as avaliações das mulheres, comparadas com as dos homens, consideraram 0 
ambiente mais satisfatório/ harmonioso/ confortável/ reduzido/ tranquilizante/ opaco/ simples/ frio.

Com relação à cor dos olhos, para a cor de iluminação laranja (Figura 5.29), pessoas com olhos escuros, comparando-se com pessoas de olhos claros, consideraram a iluminação mais distorcida/ favorece a sociabilidade. Para a cor de iluminação branco $3000 \mathrm{~K}$ (Figura 5.30), todos os pares de adjetivos apresentaram valores significantemente diferentes entre pessoa de olhos claros comparadas com pessoas de olhos escuros, havendo grande influência da cor dos olhos na percepção da qualidade da cor de iluminação do ambiente.

Com relação ao índice de massa corporal, não há diferenças de percepção da qualidade do ambiente para a cor de iluminação laranja (Figura 5.31). Para a cor de iluminação branco $3000 \mathrm{~K}$ (Figura 5.32), pessoas com IMC>25, quando comparadas com pessoas com IMC<25, consideraram o ambiente mais distorcido/ insatisfatório/ disfuncional/ desarmonioso/ alegre/ bonito/ favorece a sociabilidade/ estimulante/ brilhante/ sofisticado/ colorido.

De modo geral para a cor de iluminação laranja não há diferenças nas avaliações em função das características físicas das pessoas, porém para a cor de iluminação branco $3000 \mathrm{~K}$ as diferenças nas avaliações são significativas.

Conforme literatura estudada (LACY, 2007)), as cores de iluminação vermelha e laranja, que são cores quentes, são mais adequadas para a alimentação. Em função desse histórico esperava-se uma maior aprovação do ambiente iluminado com uma cor quente (laranja), o que ocorreu, comprovando os dados obtidos da literatura. 


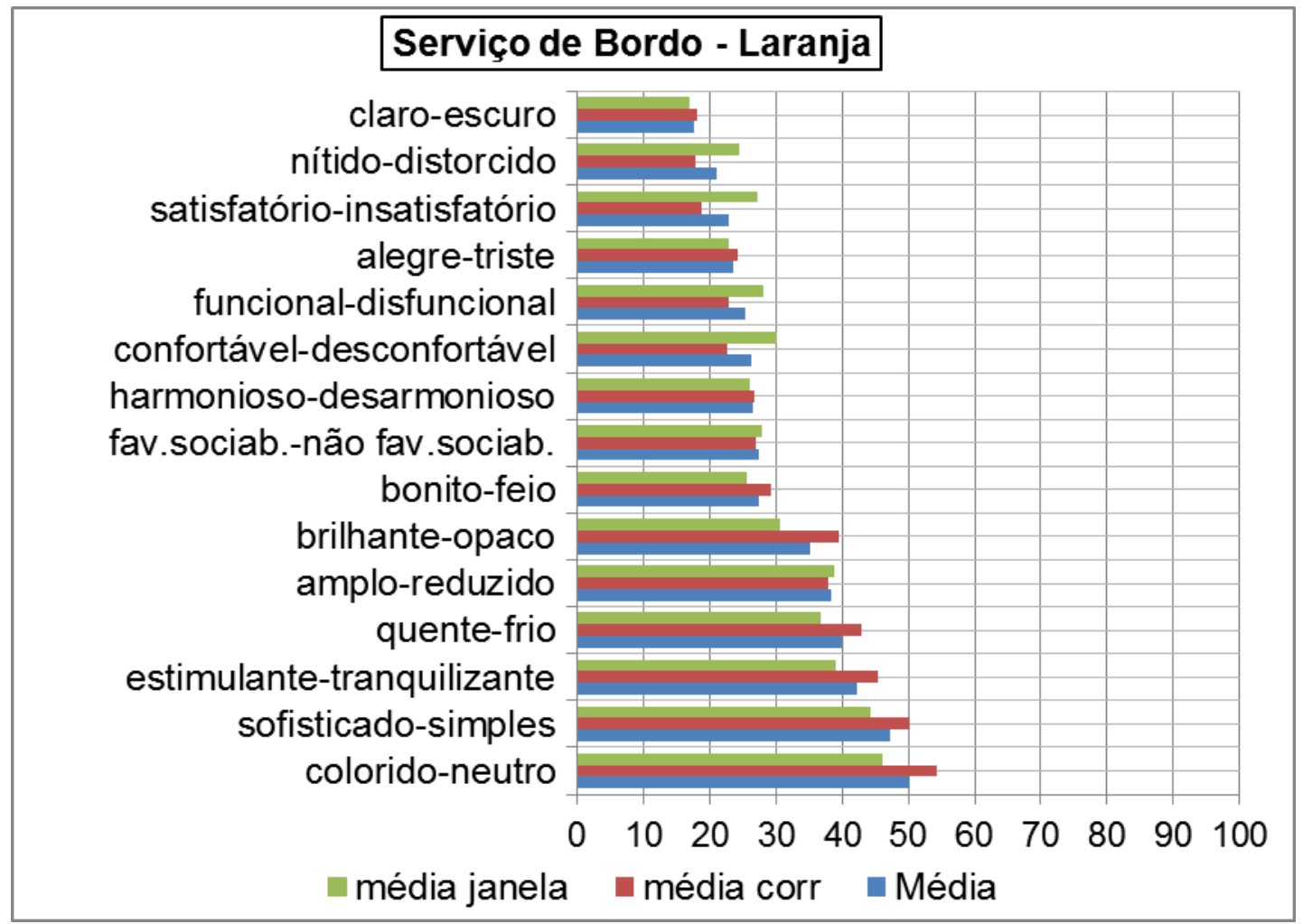

Figura 5.25 Médias obtidas dos diferenciais semânticos para o Serviço de Bordo cor da iluminação Laranja

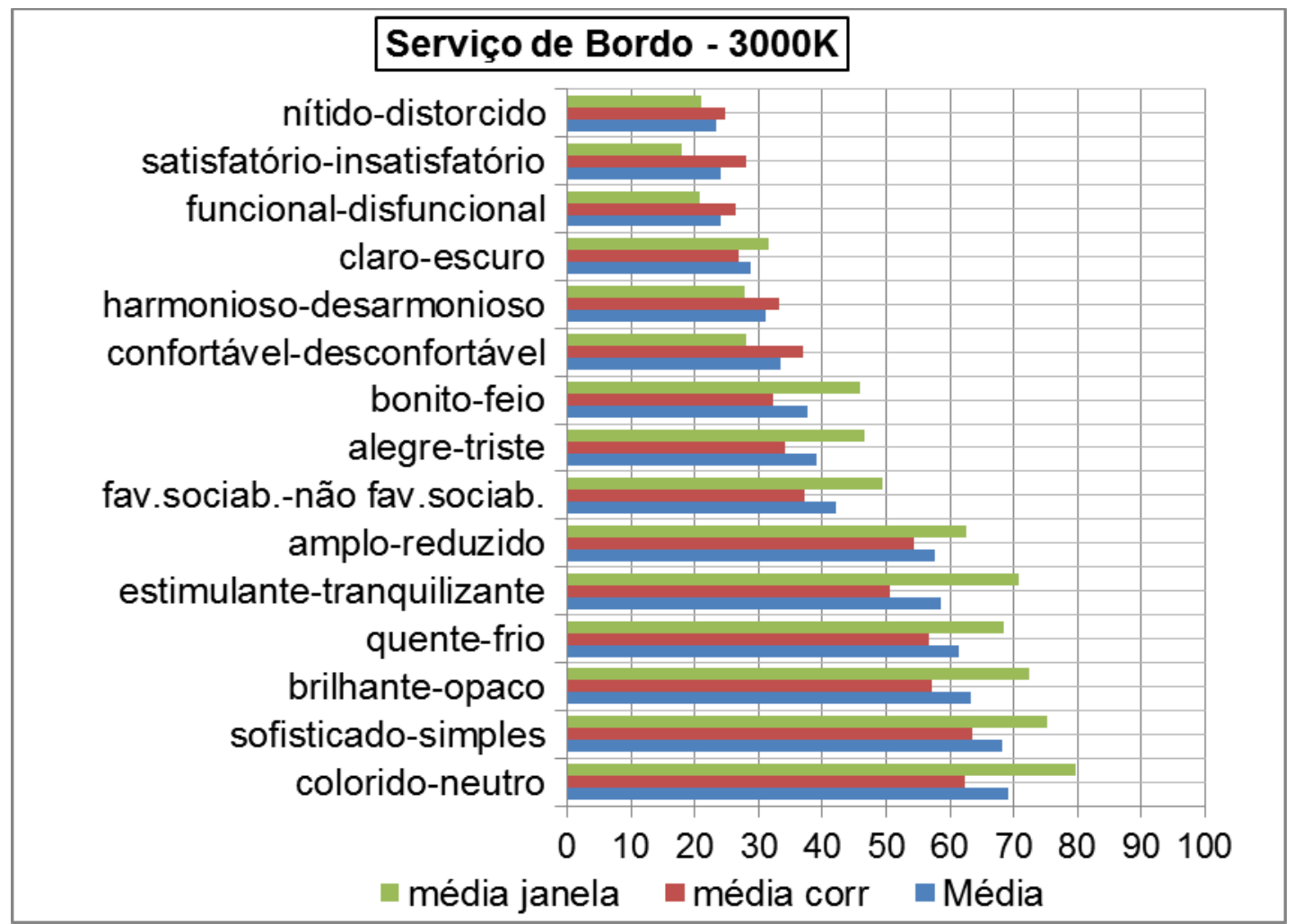

Figura 5.26 Médias obtidas dos diferenciais semânticos para o Serviço de Bordo cor da iluminação Branco 3000K 


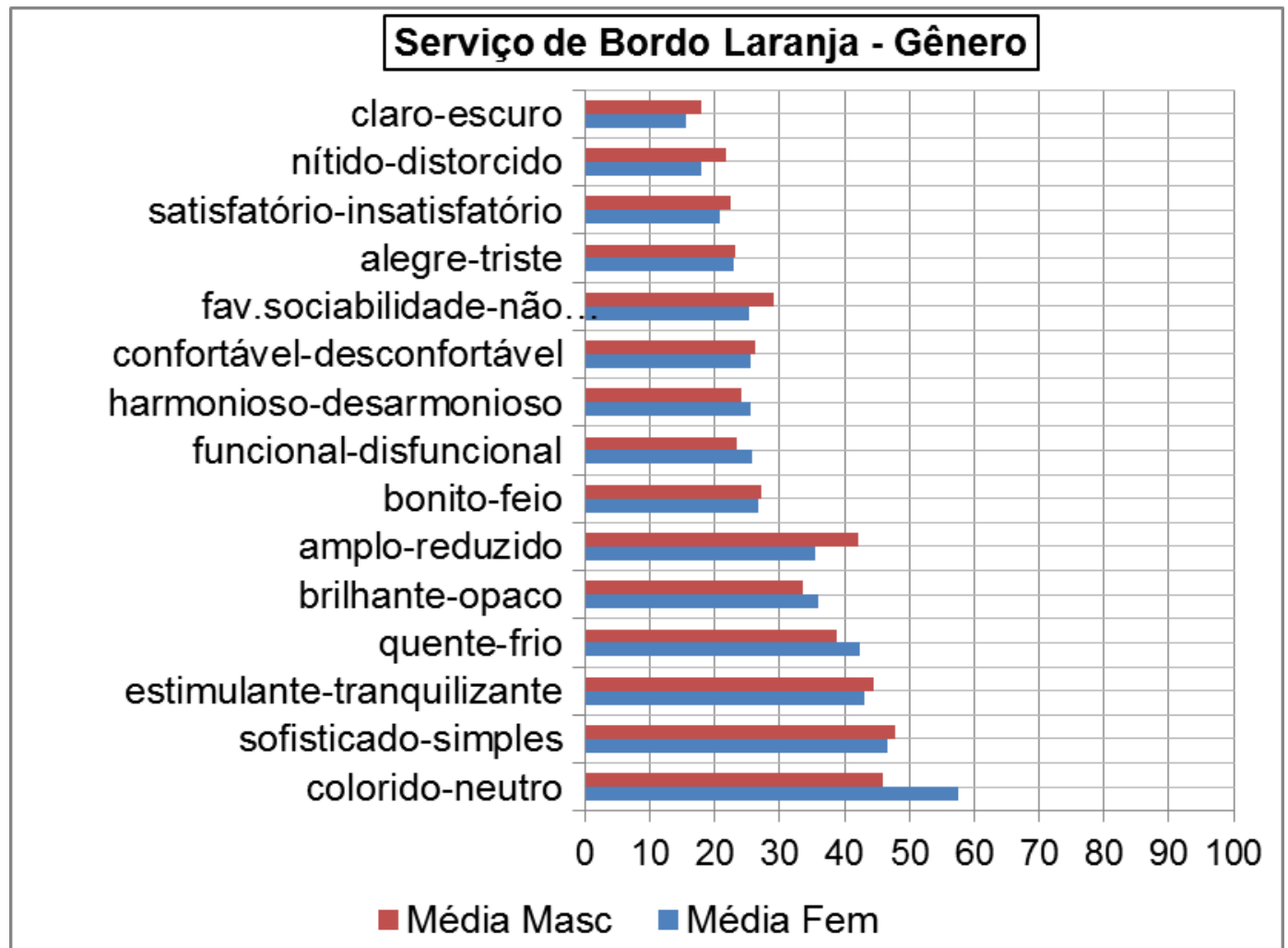

Figura 5.27 Médias obtidas dos diferenciais semânticos para o Serviço de Bordo cor da iluminação Laranja - Gênero

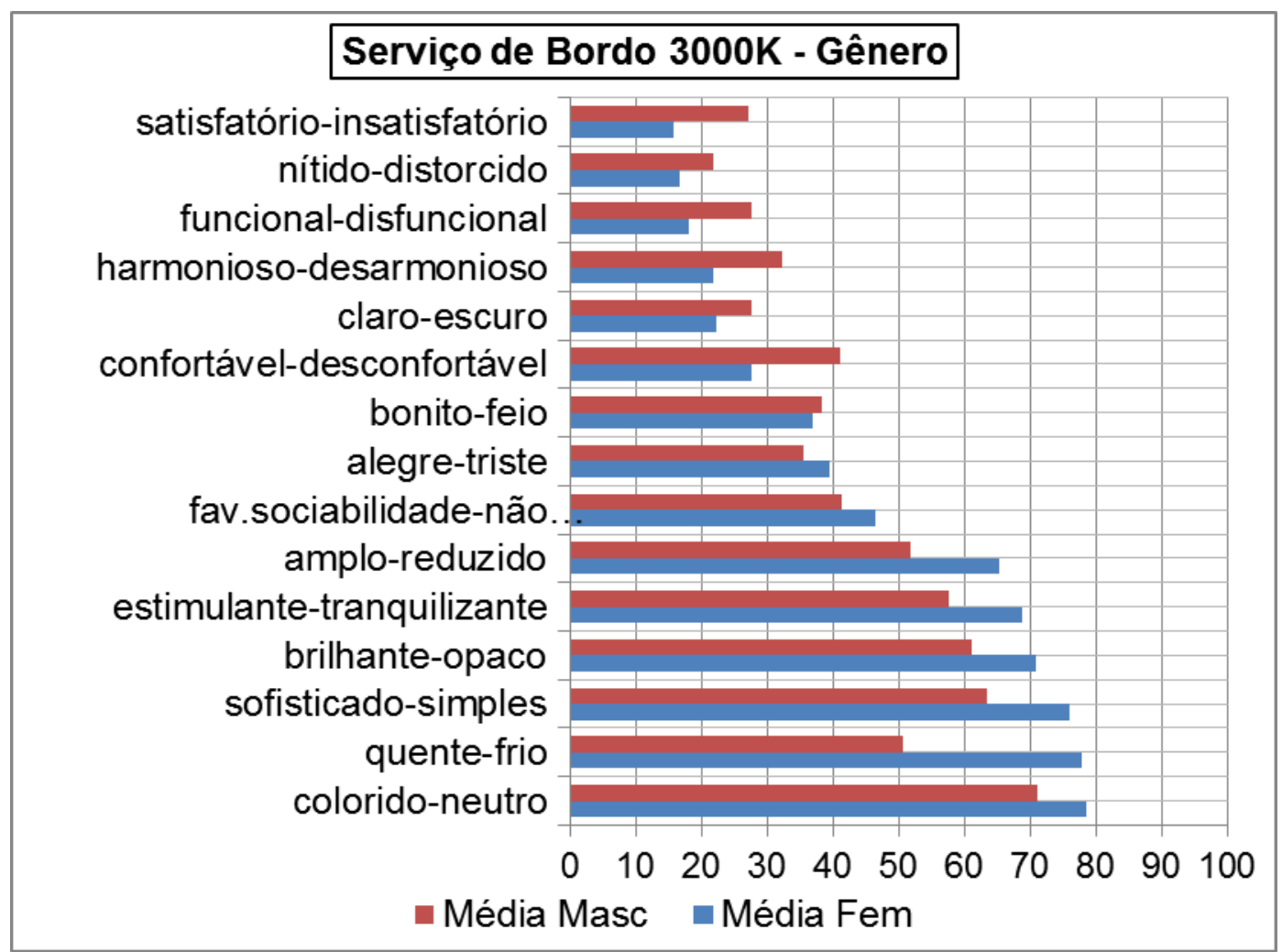

Figura 5.28 Médias obtidas dos diferenciais semânticos para o Serviço de Bordo cor da iluminação Branco 3000K - Gênero 


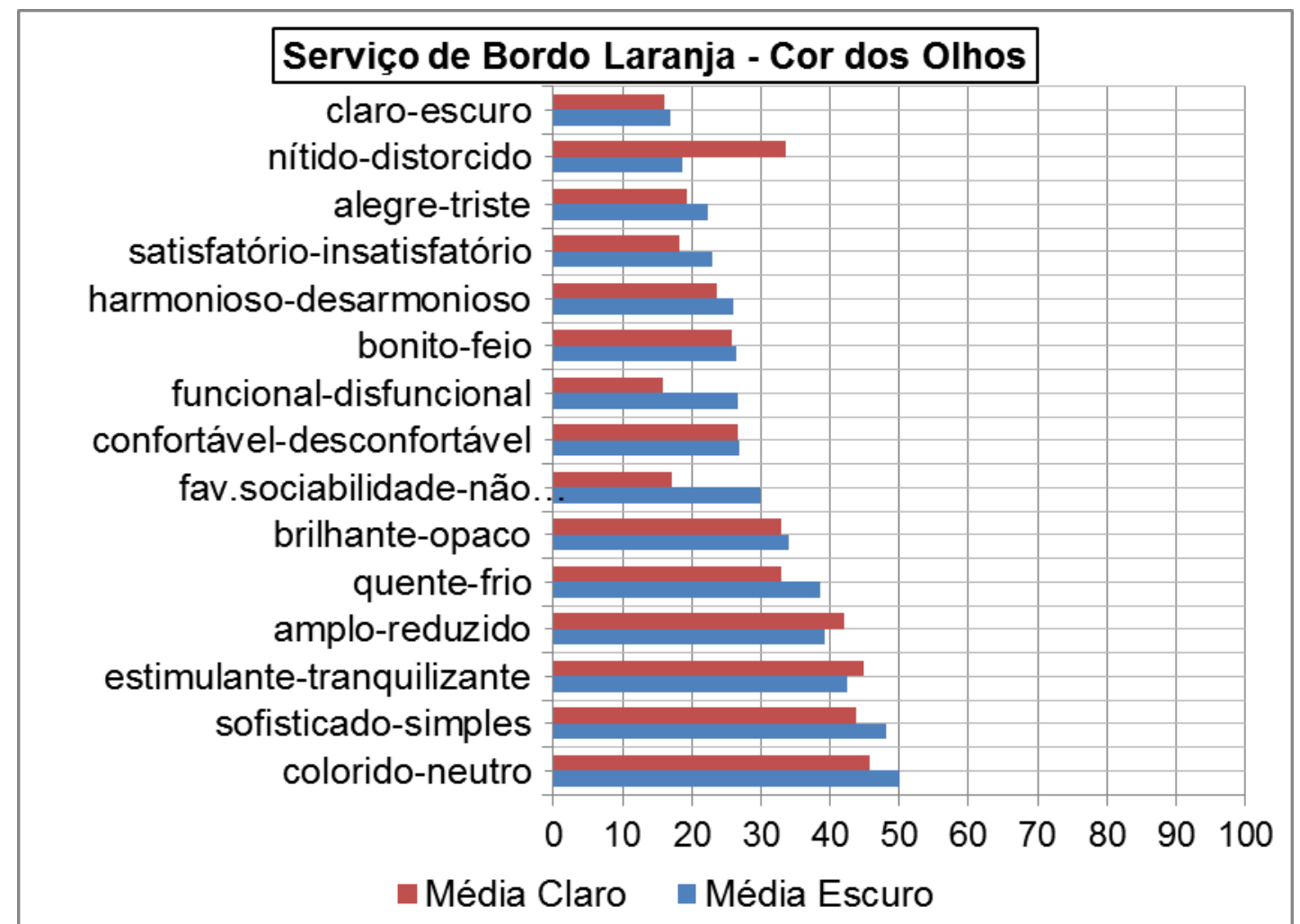

Figura 5.29 Médias obtidas dos diferenciais semânticos para o Serviço de Bordo cor da iluminação Laranja - Cor dos Olhos

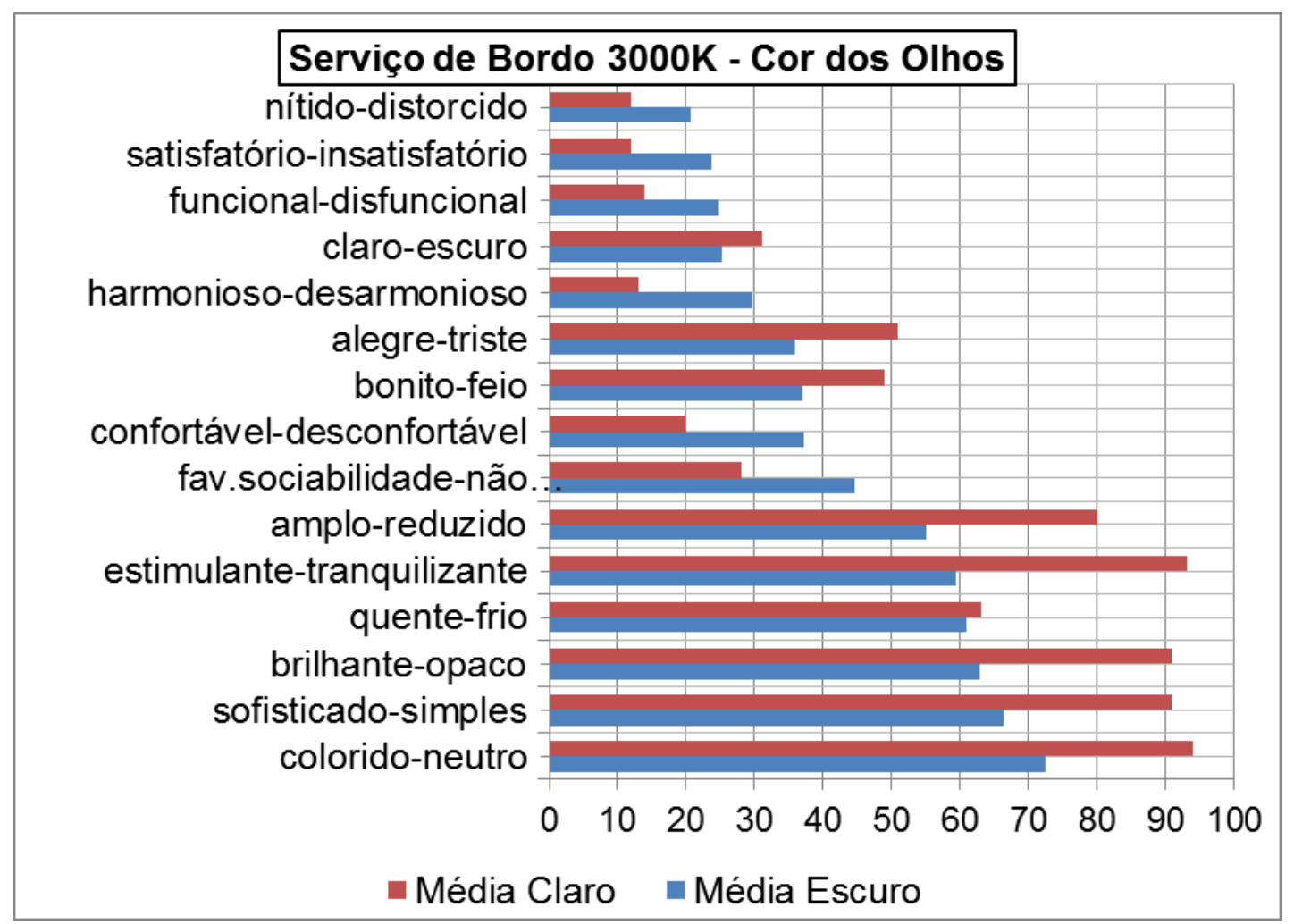

Figura 5.30 Médias obtidas dos diferenciais semânticos para o Serviço de Bordo cor da iluminação Branco 3000K - Cor dos Olhos 


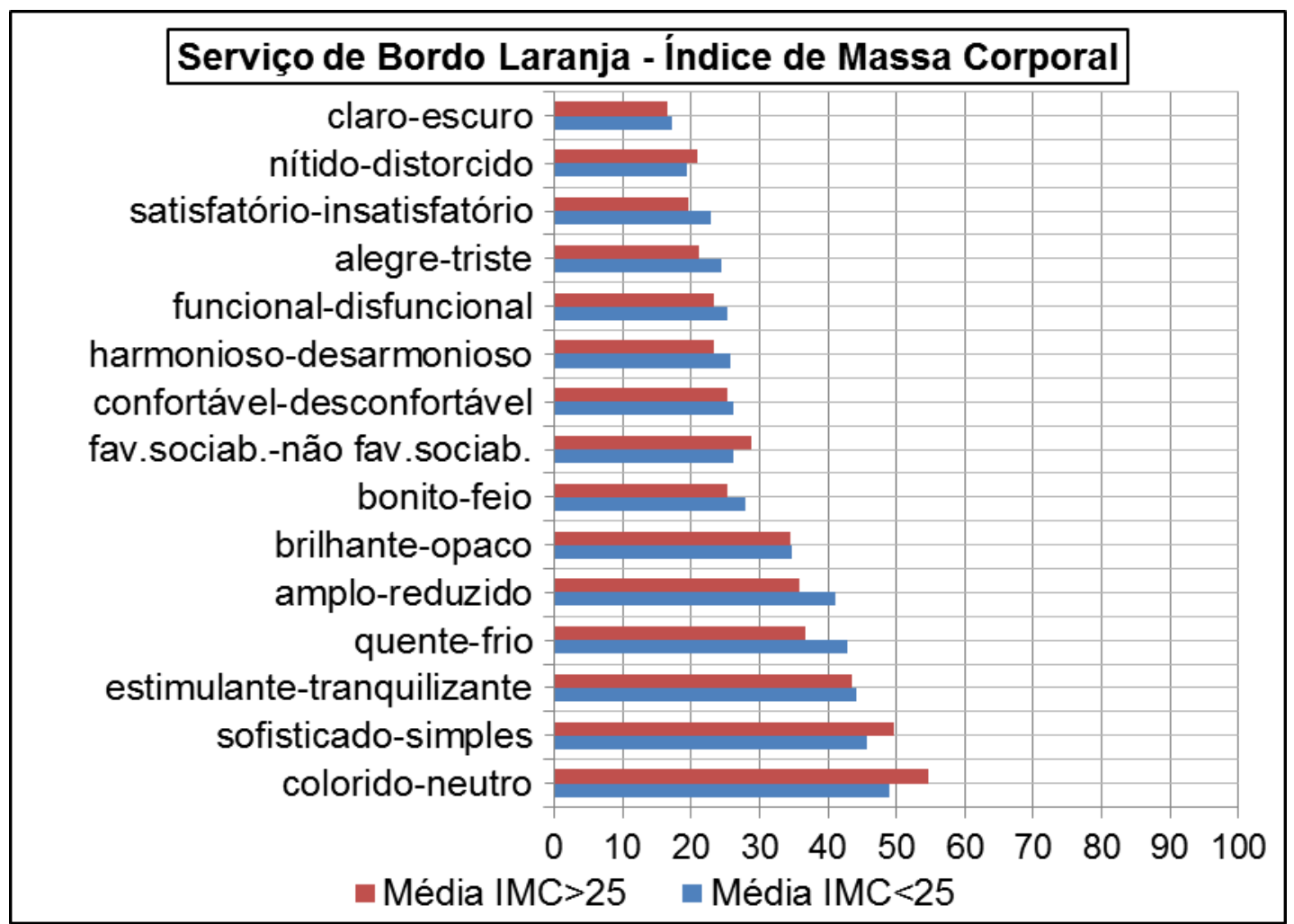

Figura 5.31 Médias obtidas dos diferenciais semânticos para o Serviço de Bordo cor da iluminação Laranja - Índice de Massa Corporal

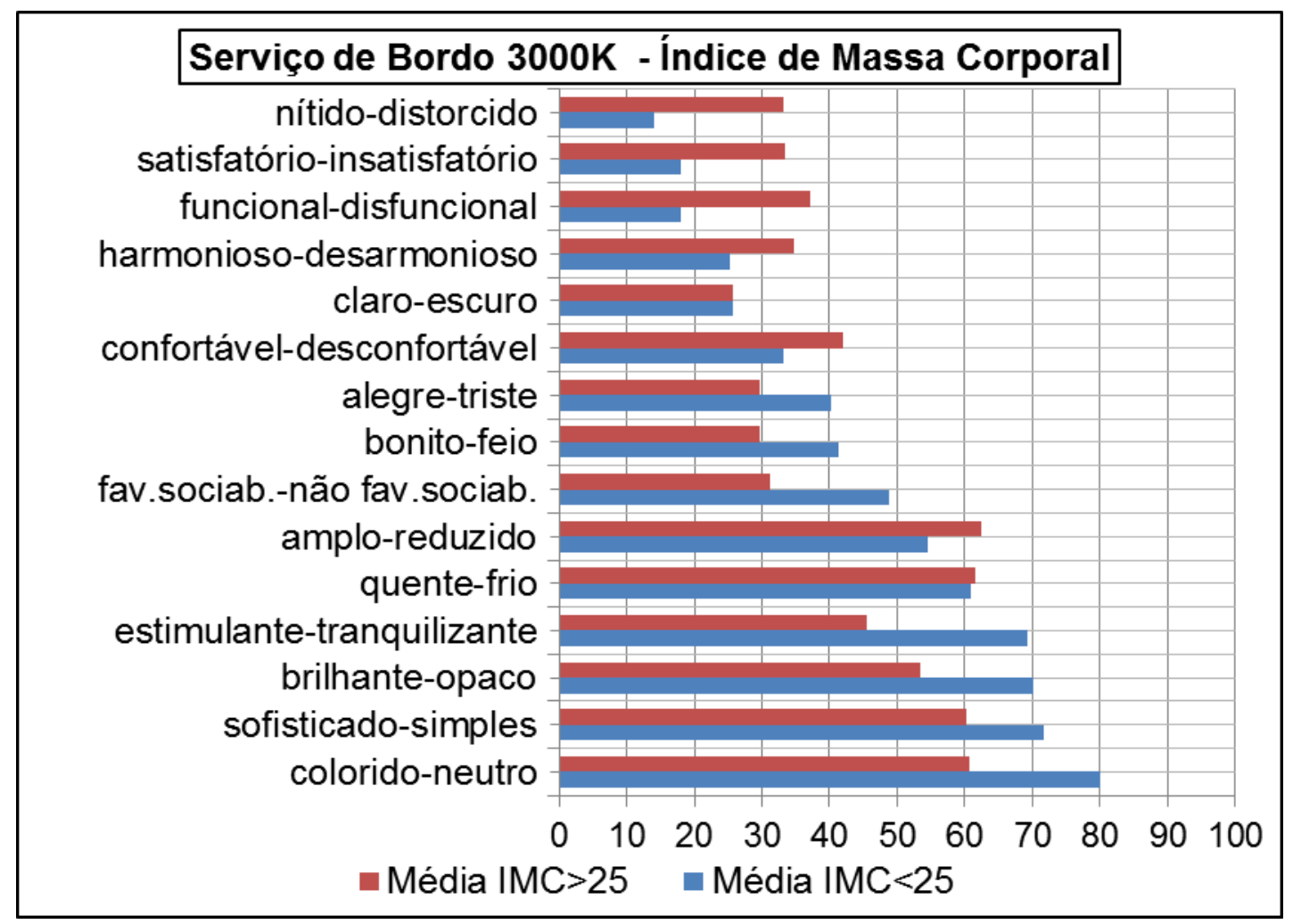

Figura 5.32 Médias obtidas dos diferenciais semânticos para o Serviço de Bordo cor da iluminação Branco 3000K - Índice de Massa Corporal 


\subsubsection{Cruzeiro 2}

Nessa fase, fase de descontração e descanso, as pessoas já estão mais adaptadas ao ambiente da cabine mockup.

As médias obtidas dos diferenciais semânticos estão mostradas da Figura 5.33 até a Figura 5.40. Nestas figuras o eixo da abcissa representa as médias obtidas considerando valores de 0 a 100 pontos e a ordenada representa os pares de adjetivos. Valores abaixo de 50 pontos são valores mais próximos de adjetivos do lado esquerdo do par de adjetivos e valores acima de 50 pontos são valores mais próximos de adjetivos do lado direito do par de adjetivos.

Considerando-se médias abaixo de 40 pontos, os participantes da pesquisa consideraram a iluminação do ambiente, nessa fase do voo, com relação à cor da iluminação azul, de modo geral positivo, sendo essa iluminação adequada para essa fase do voo.

Para a cor de iluminação azul (Figura 5.33), as médias dos pontos dos adjetivos bipolares auferidos pelos avaliadores sentados próximo à janela apresentaram valores parecidos aos dos avaliadores próximos do corredor, ou seja, a localização dos passageiros não influenciou na sua avaliação da qualidade do ambiente.

Com a cor "Branco 4000K" (Figura 5.34), as médias obtidas para os adjetivos bipolares, para os avaliadores sentados próximos à janela, apresentaram valores superiores aos das pessoas sentadas no corredor, ou seja, é uma iluminação menos adequada para as pessoas sentadas na janela, talvez pela falta de homogeneidade de iluminação.

Para a cor de iluminação branco 4000K, a qualidade do ambiente foi classificada como sendo mais nítido/ claro/ funcional/ satisfatório/ harmonioso/ simples/ tranquilizante/ neutro.

Quanto à avaliação da qualidade do ambiente em função das características físicas dos avaliadores, levando-se em consideração o gênero do passageiro, para a cor de iluminação azul (Figura 5.35) as avaliações das mulheres, comparando-se com as dos homens, classificaram a qualidade do ambiente mais sofisticado e brilhante. Para a 
cor de iluminação branco 4000K (Figura 5.36), as mulheres classificaram o ambiente como sendo mais harmonioso/ reduzido/ opaco/ simples/ neutro comparado à classificação dos homens.

Quanto à cor dos olhos, para a cor de iluminação azul (Figura 5.37), pessoas com olhos de cor escura, comparando-se com pessoas de olhos claros, consideraram a qualidade do ambiente como sendo mais feio/ não favorece a sociabilidade/ amplo/ frio/ neutro. Para a cor de iluminação 4000K (Figura 5.38) houve diferenças significativas nas avaliações em todos os pares de adjetivos, ou seja, a cor dos olhos tem importância quando se utiliza uma iluminação branca.

Com relação ao Índice de Massa Corporal, não houve diferenças nas avaliações para a cor de iluminação azul (Figura 5.39). Para a cor de iluminação branco 4000K (Figura 5.40), as avaliações da qualidade do ambiente para pessoas com IMC>25, comparando-se com pessoas com IMC $<25$, consideraram o ambiente mais distorcido/ escuro/ disfuncional/ insatisfatório/ desarmonioso/ reduzido/ favorece a sociabilidade/ brilhante/ colorido.

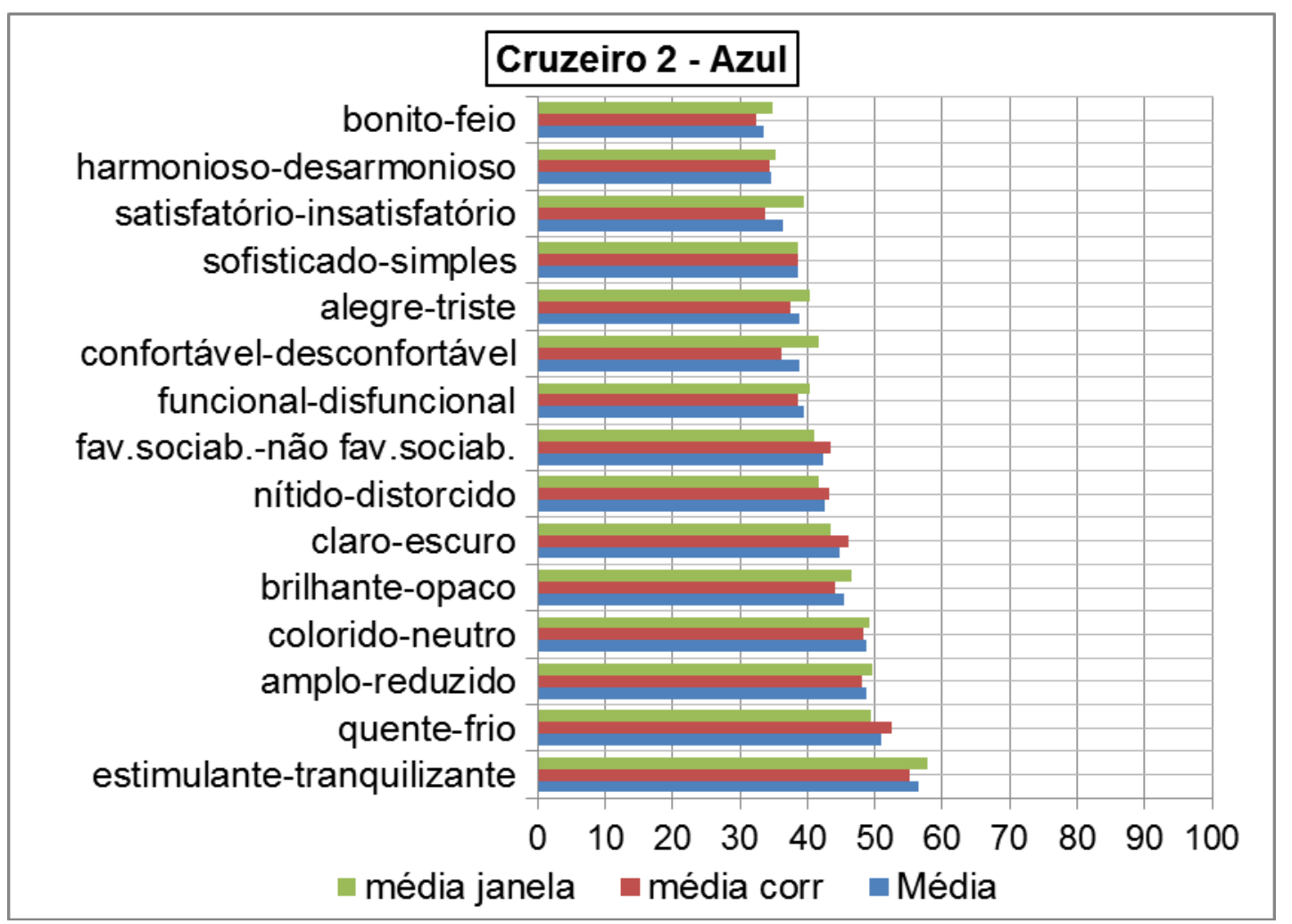

Figura 5.33 Médias obtidas dos diferenciais semânticos para o Cruzeiro 2 cor da iluminação Azul 


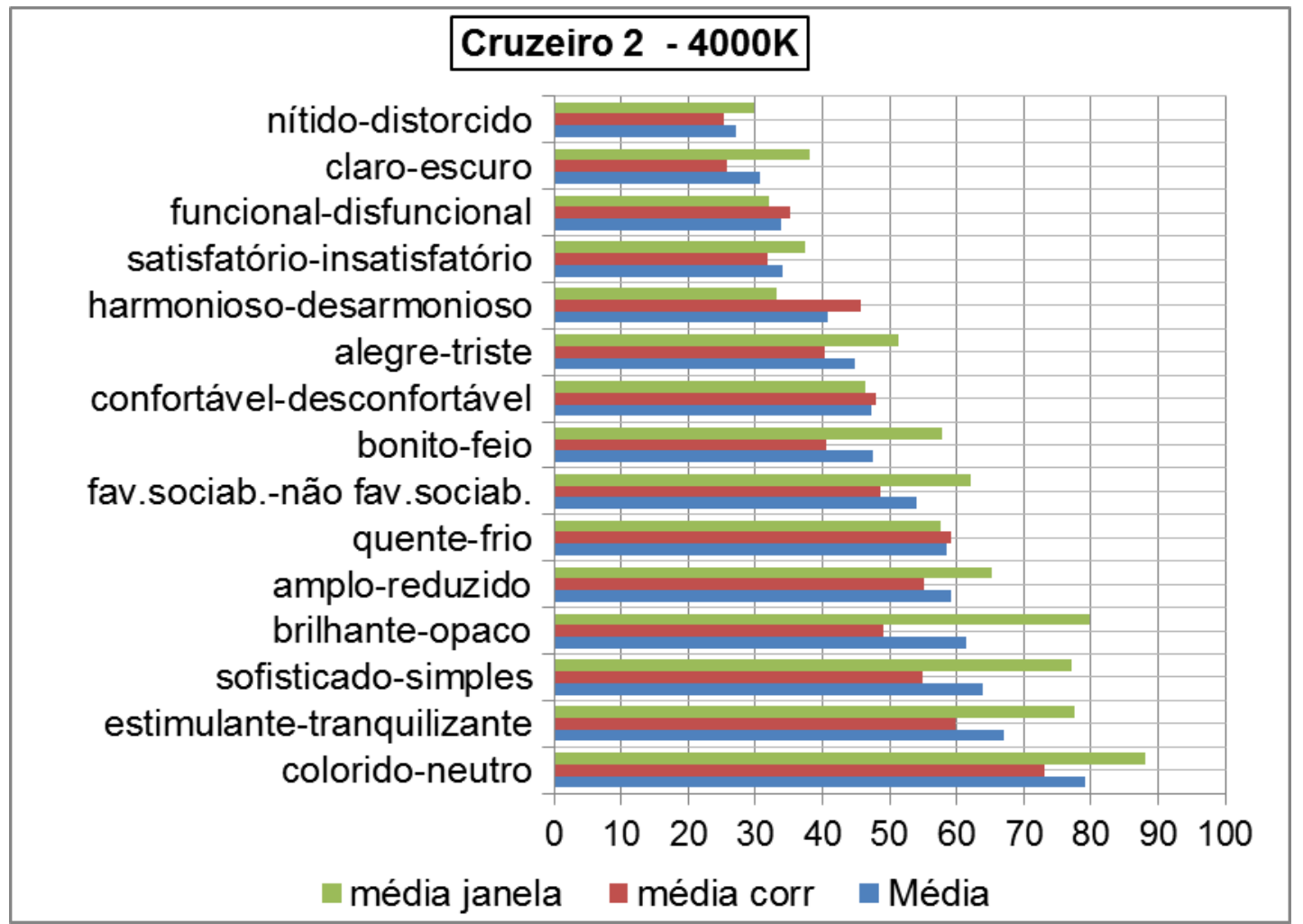

Figura 5.34 Médias obtidas dos diferenciais semânticos para o Cruzeiro 2 cor da iluminação Branco 4000K

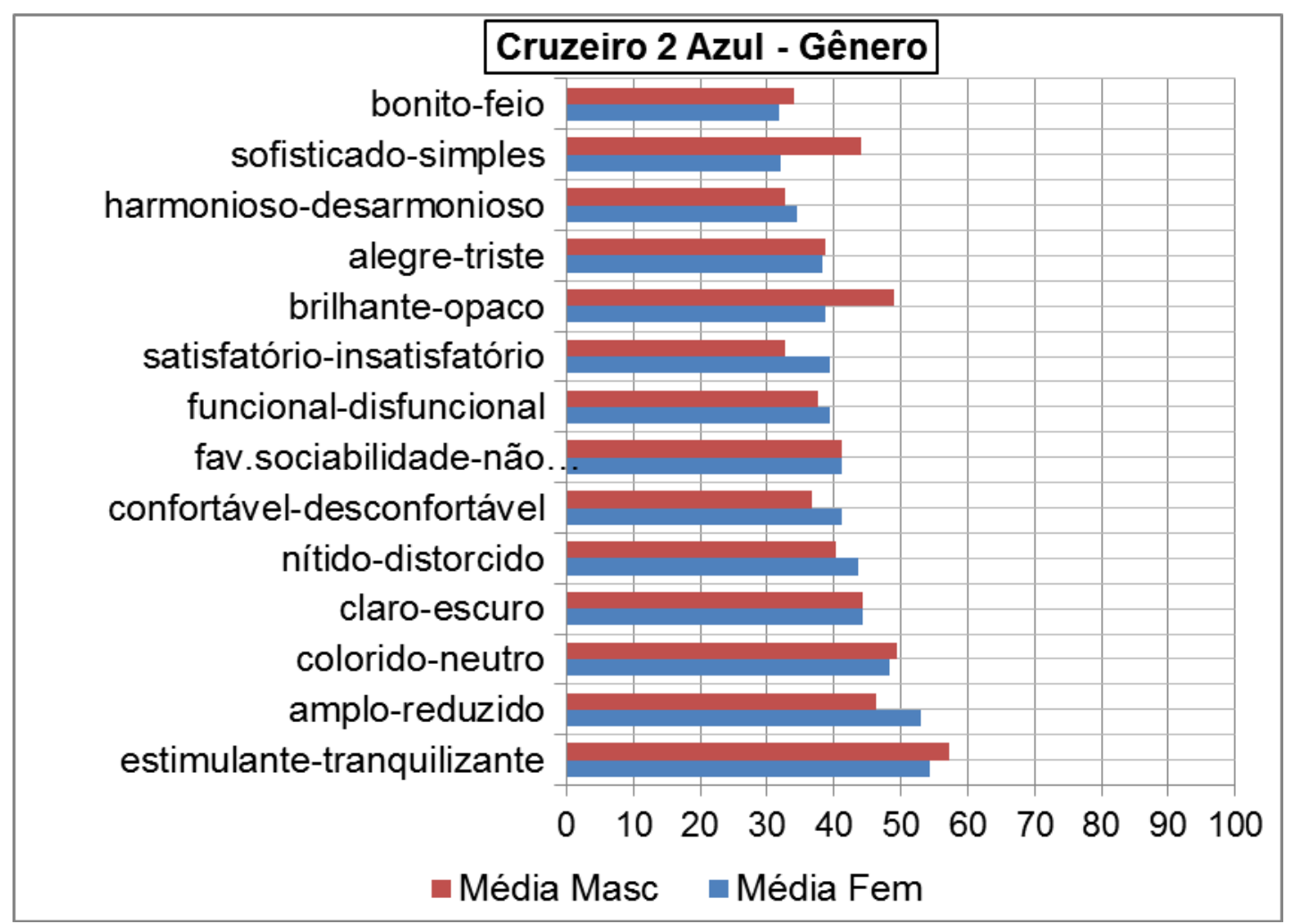

Figura 5.35Médias obtidas dos diferenciais semânticos para o Cruzeiro 2 cor da iluminação Azul Gênero 


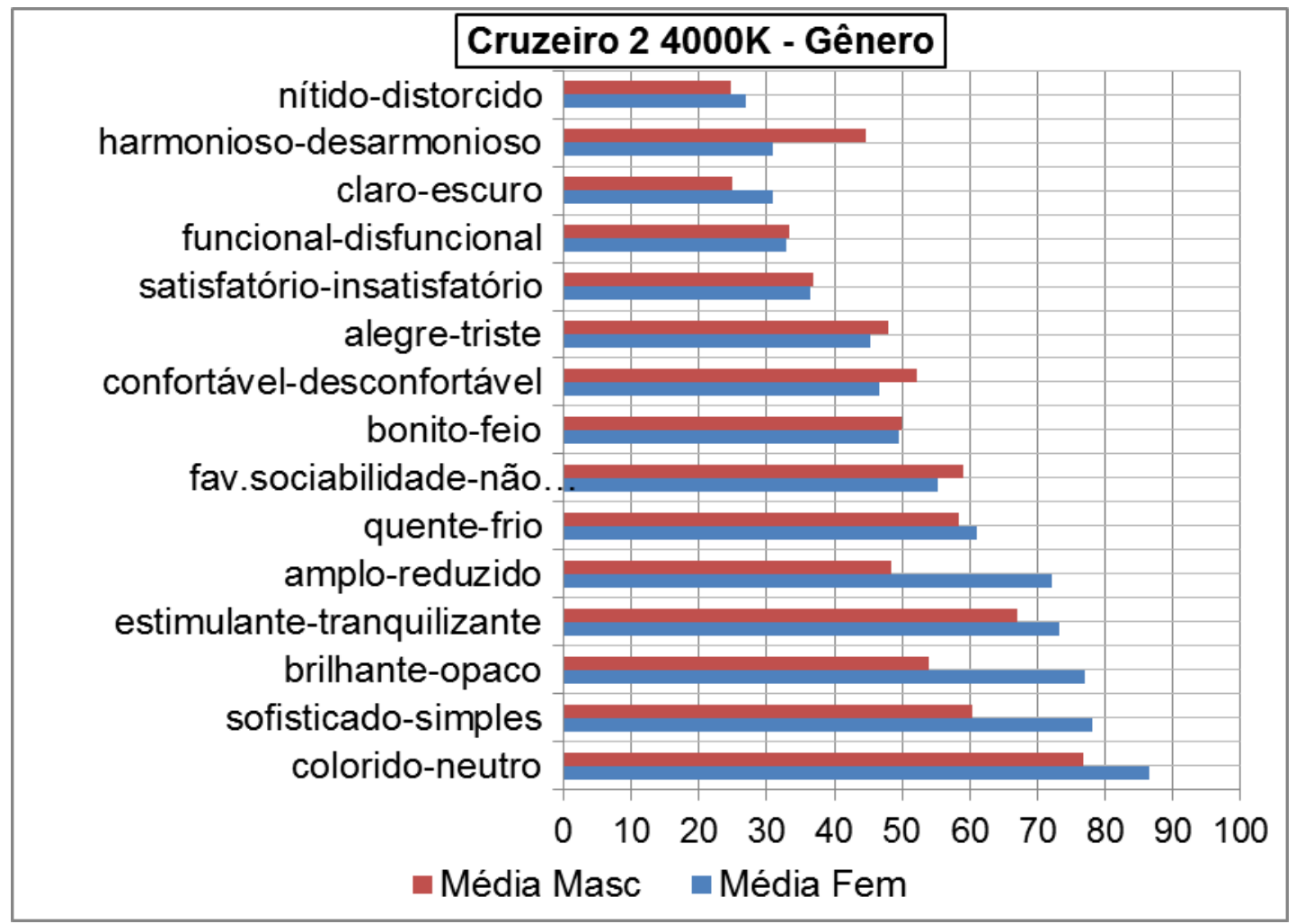

Figura 5.36 Médias obtidas dos diferenciais semânticos para o Cruzeiro 2 cor da iluminação Branco 4000K - Gênero

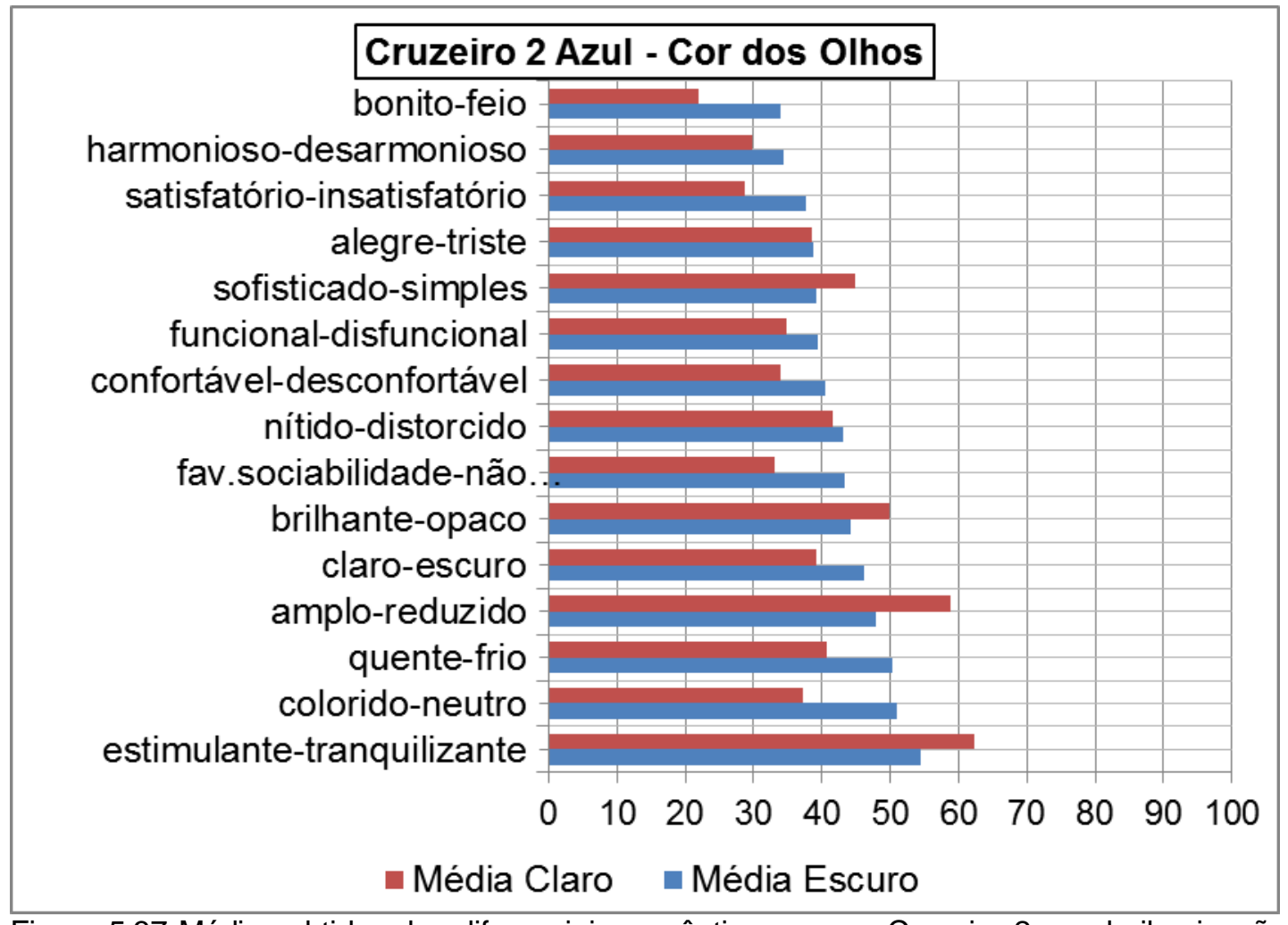

Figura 5.37 Médias obtidas dos diferenciais semânticos para o Cruzeiro 2 cor da iluminação Azul - Cor dos Olhos 


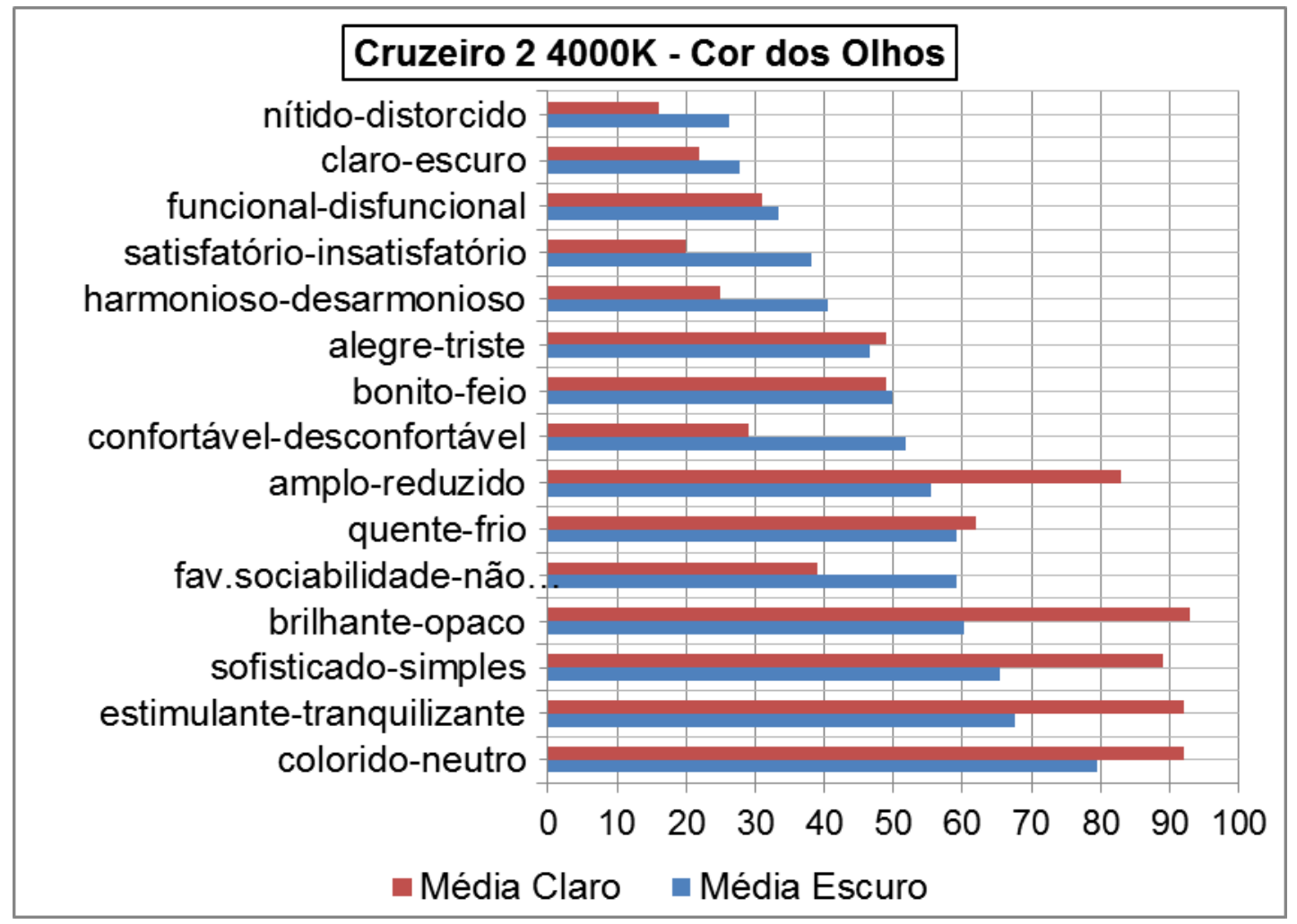

Figura 5.38 Médias obtidas dos diferenciais semânticos para o Cruzeiro 2 cor da iluminação Branco B 4000K - Cor dos Olhos

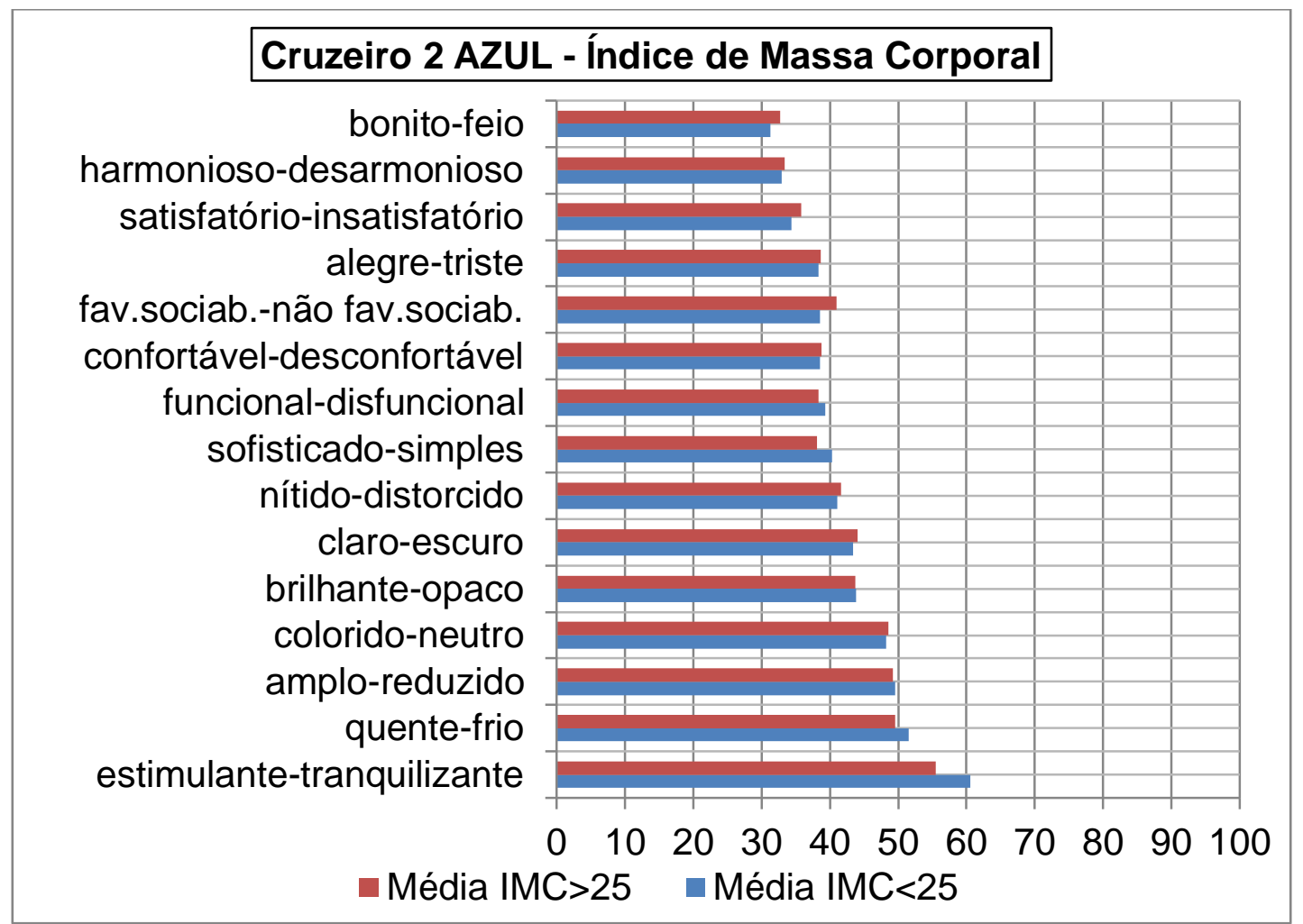

Figura 5.39 Médias obtidas dos diferenciais semânticos para o Cruzeiro 2 cor da iluminação Azul - Índice de Massa corporal 


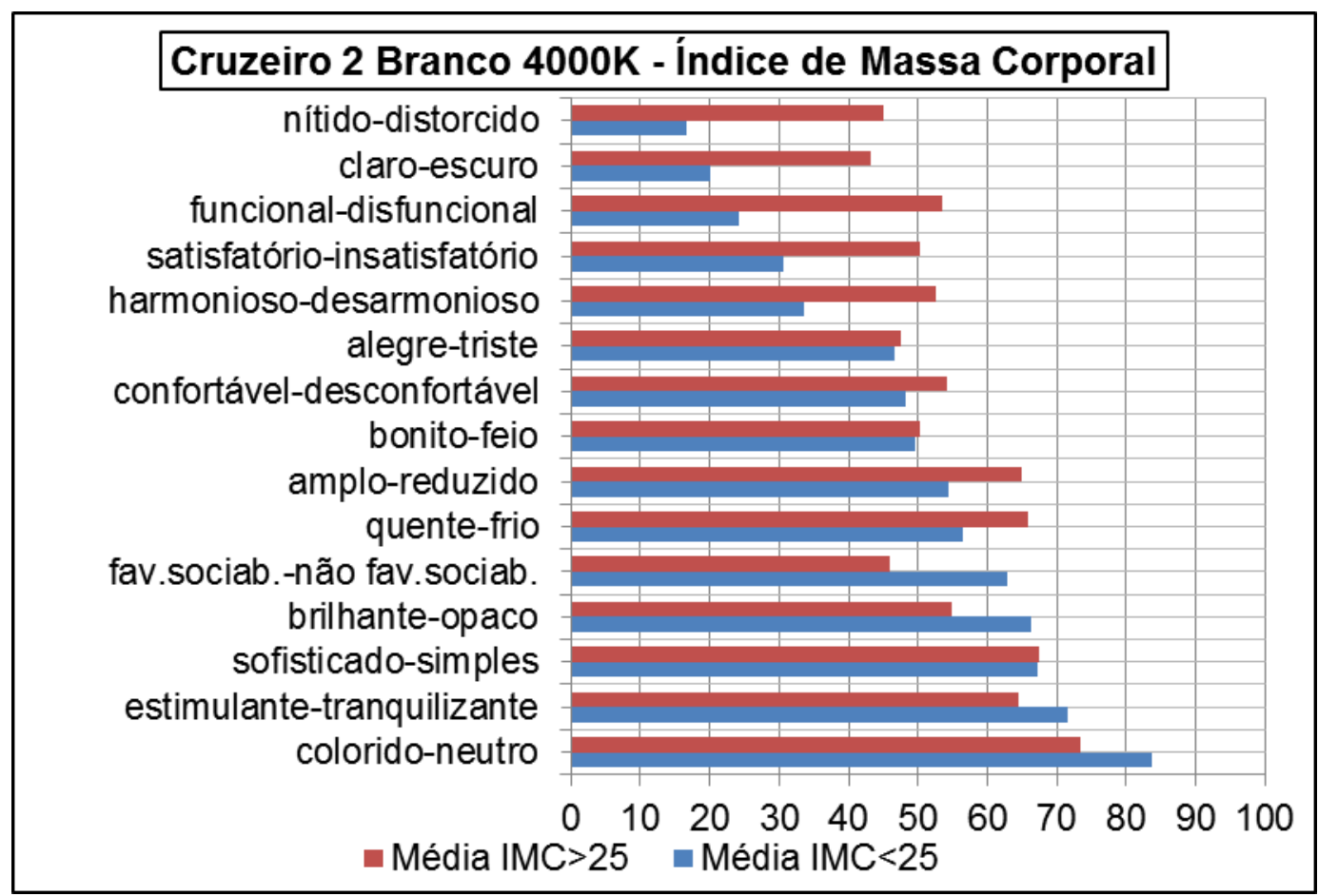

Figura 5.40 Médias obtidas dos diferenciais semânticos para o Cruzeiro 2 cor da iluminação Branco 4000K - Índice de Massa Corporal

\subsubsection{Desembarque}

Fase em que as pessoas recolhem seus pertences e saem da cabine. A avaliação é feita em uma sala fora da cabine.

As médias obtidas dos diferenciais semânticos estão mostradas da Figura 5.41 até a Figura 5.52. Nestas figuras o eixo da abcissa representa as médias obtidas considerando valores de 0 a 100 pontos e a ordenada representa os pares de adjetivos. Valores abaixo de 50 pontos são valores mais próximos de adjetivos do lado esquerdo do par de adjetivos e valores acima de 50 pontos são valores mais próximos de adjetivos do lado direito do par de adjetivos.

Considerando-se médias abaixo de 40 pontos, os participantes da pesquisa consideraram a iluminação do ambiente, nessa fase do voo, independentemente da cor da iluminação empregada, como sendo adequada, sendo que a média geral da pontuação para a cor laranja (Figura 5.41) é menor do que a da cor azul (Figura 5.42) e que é menor do que a cor branco 6000K (Figura 5.43). 
Também nessa fase, as pontuações das avaliações das pessoas sentadas próximas à janela foram idênticas as das pessoas sentadas próximas ao corredor, para as cores de iluminação azul.

Com a cor de iluminação Laranja, as médias obtidas para os adjetivos bipolares para os avaliadores sentados próximos à janela, foram diferentes às médias das pessoas sentadas no corredor, evidenciando a não uniformidade da iluminação ou diferenças ergonômicas entre corredor e janela.

Com a cor de iluminação Branco $6000 \mathrm{~K}$, as médias obtidas para os adjetivos bipolares, para os avaliadores sentados próximos à janela, foram superiores às médias das pessoas sentadas no corredor, evidenciando-se uma menor aceitação desta cor da iluminação, talvez pelo fato dos avaliadores, quando em pé, ficarem mais próximos da fonte de luz para esses adjetivos.

Considerando-se os aspectos físicos dos indivíduos, observam-se algumas diferenças significativas de percepção do homem em relação à mulher. Para a cor de iluminação laranja (Figura 5.44) a mulher, comparando-se com o homem, considerou a qualidade do ambiente como sendo mais claro/ estimulante. Para a cor de iluminação azul (Figura 5.45), o gênero feminino considerou a iluminação do ambiente como sendo mais reduzido, quando comparado com a observação do homem. Para uma cor da iluminação branco 6000K (Figura 5.46), a percepção da mulher, em relação à percepção do homem, considerou a qualidade do ambiente como sendo mais satisfatório/ funcional/ harmonioso/ bonito/ confortável/ favorece a sociabilidade/ frio.

Com relação à cor dos olhos (Figuras 5.47, 5.48 e 5.49), observou-se uma grande variação nos resultados quando se compara a percepção da qualidade do ambiente feita por pessoas de olhos claros comparadas com pessoas de olhos escuros, independentemente da cor da iluminação empregada.

Com relação ao índice de massa corporal, a percepção da qualidade do ambiente para uma cor de iluminação laranja (Figura 5.50), pessoas com IMC>25, comparandose com pessoas com $\mathrm{IMC}<25$, percebem o ambiente como sendo mais triste/ insatisfatório/ feio. Para a cor da iluminação azul (Figura 5.51) não se observou variações de avaliações da qualidade do ambiente, em função do IMC. Para uma cor da iluminação branco 6000K (Figura 5.52), observou-se diferenças significativas das 
avaliações da percepção da qualidade do ambiente em quase todos os pares de adjetivos.

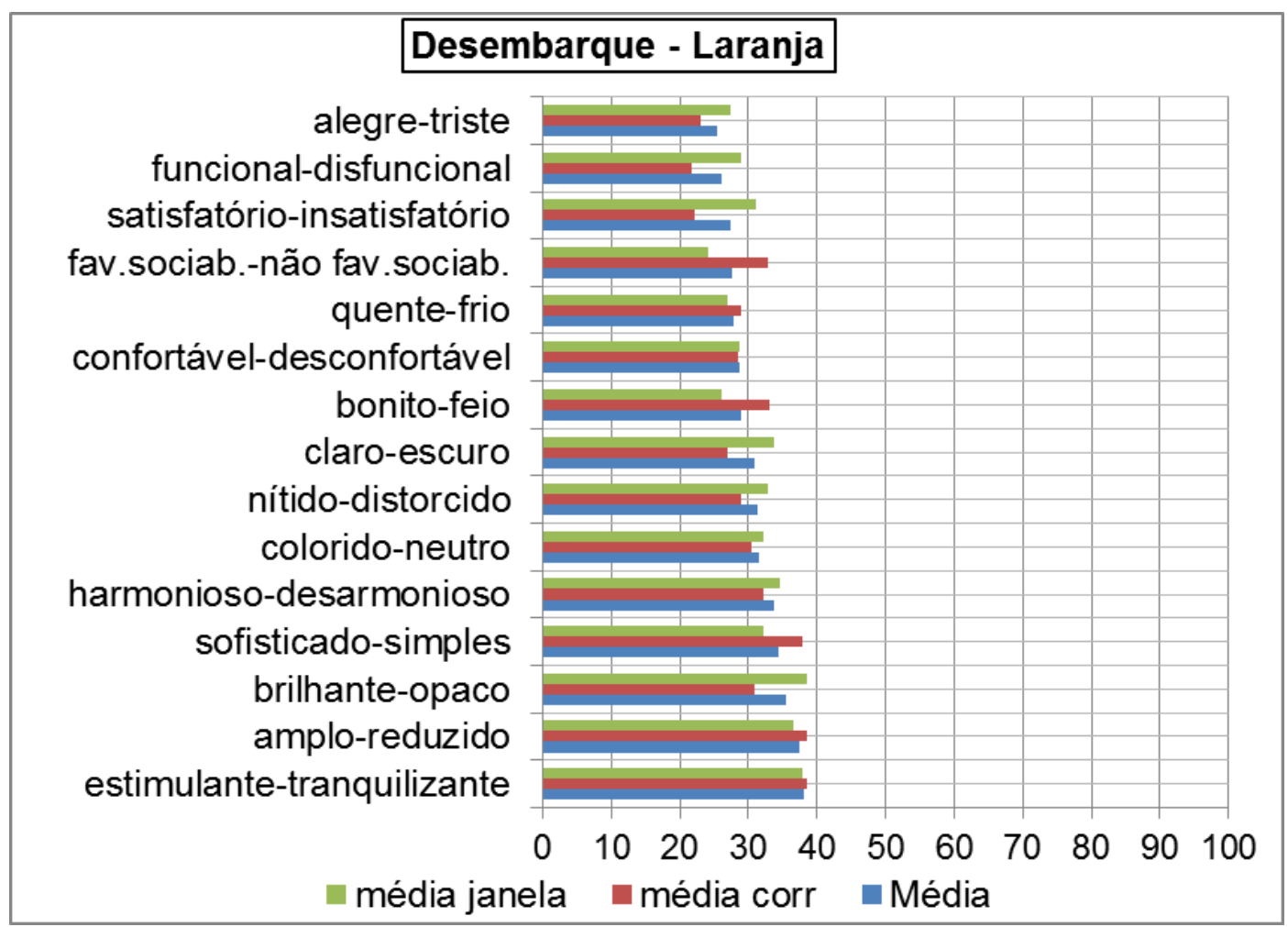

Figura 5.41 Médias obtidas dos diferenciais semânticos para o Desembarque cor da iluminação laranja

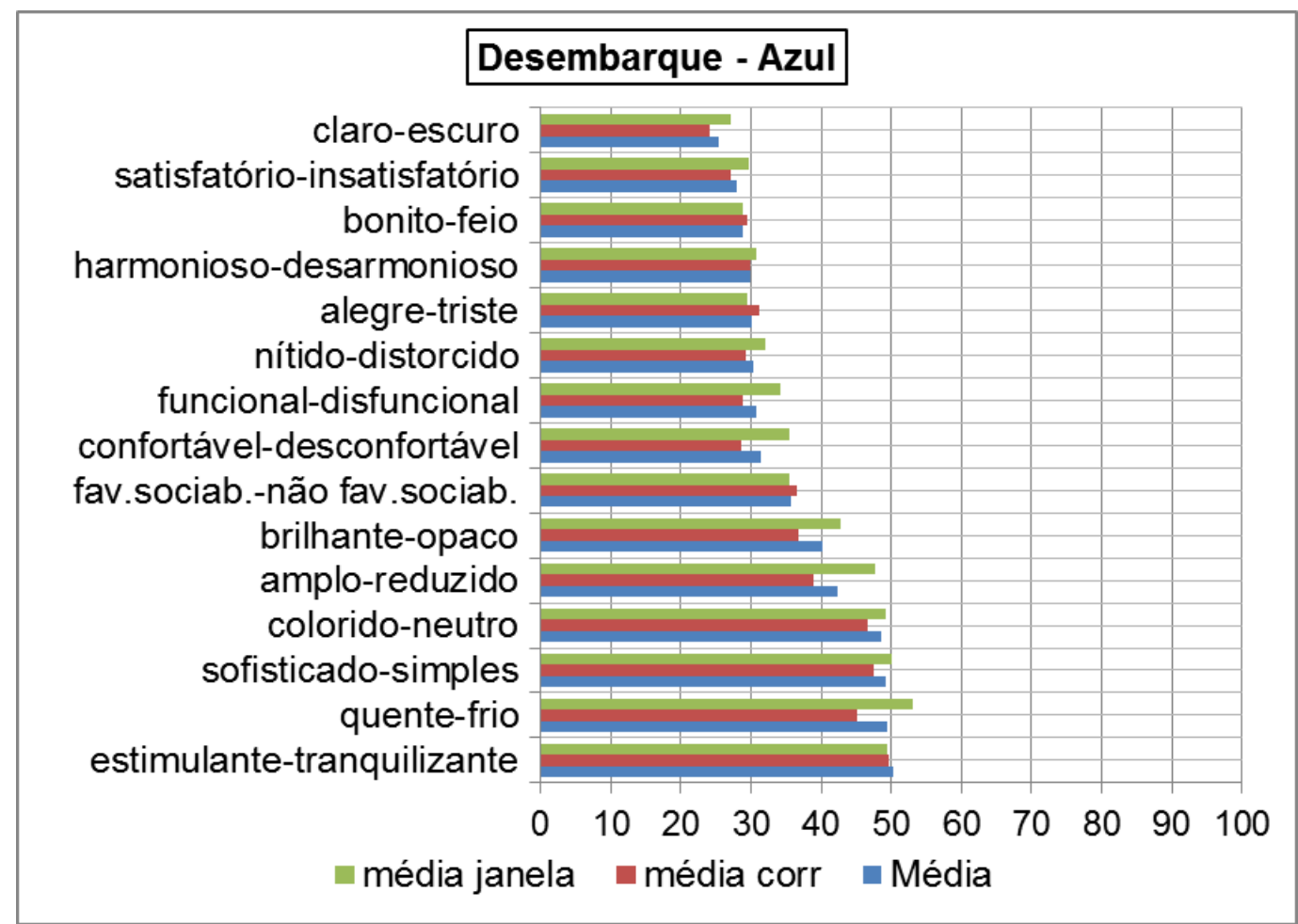

Figura 5.42 Médias obtidas dos diferenciais semânticos para o Desembarque cor da iluminação Azul 


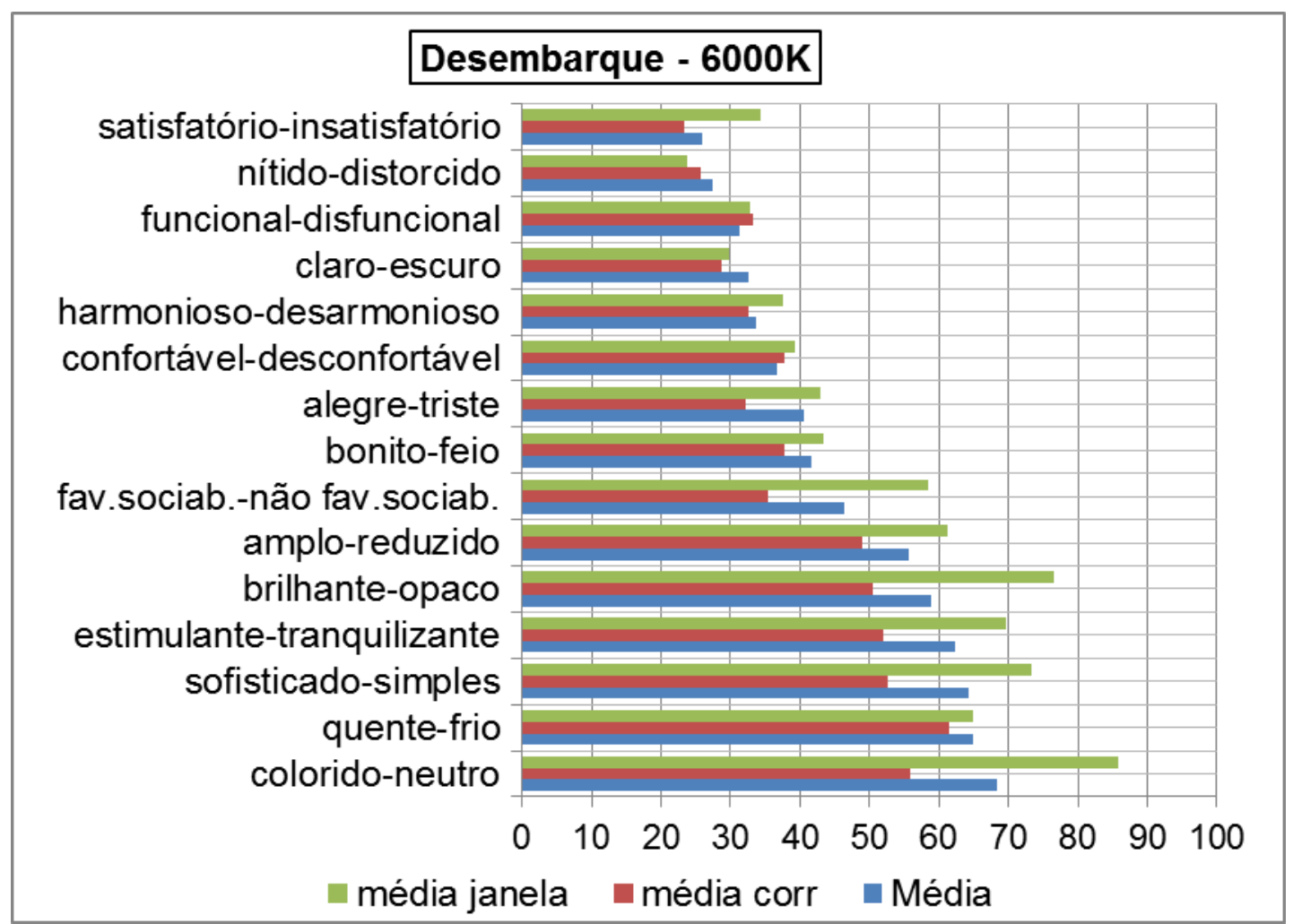

Figura 5.43 Médias obtidas dos diferenciais semânticos para o Desembarque cor da iluminação Branco 6000K

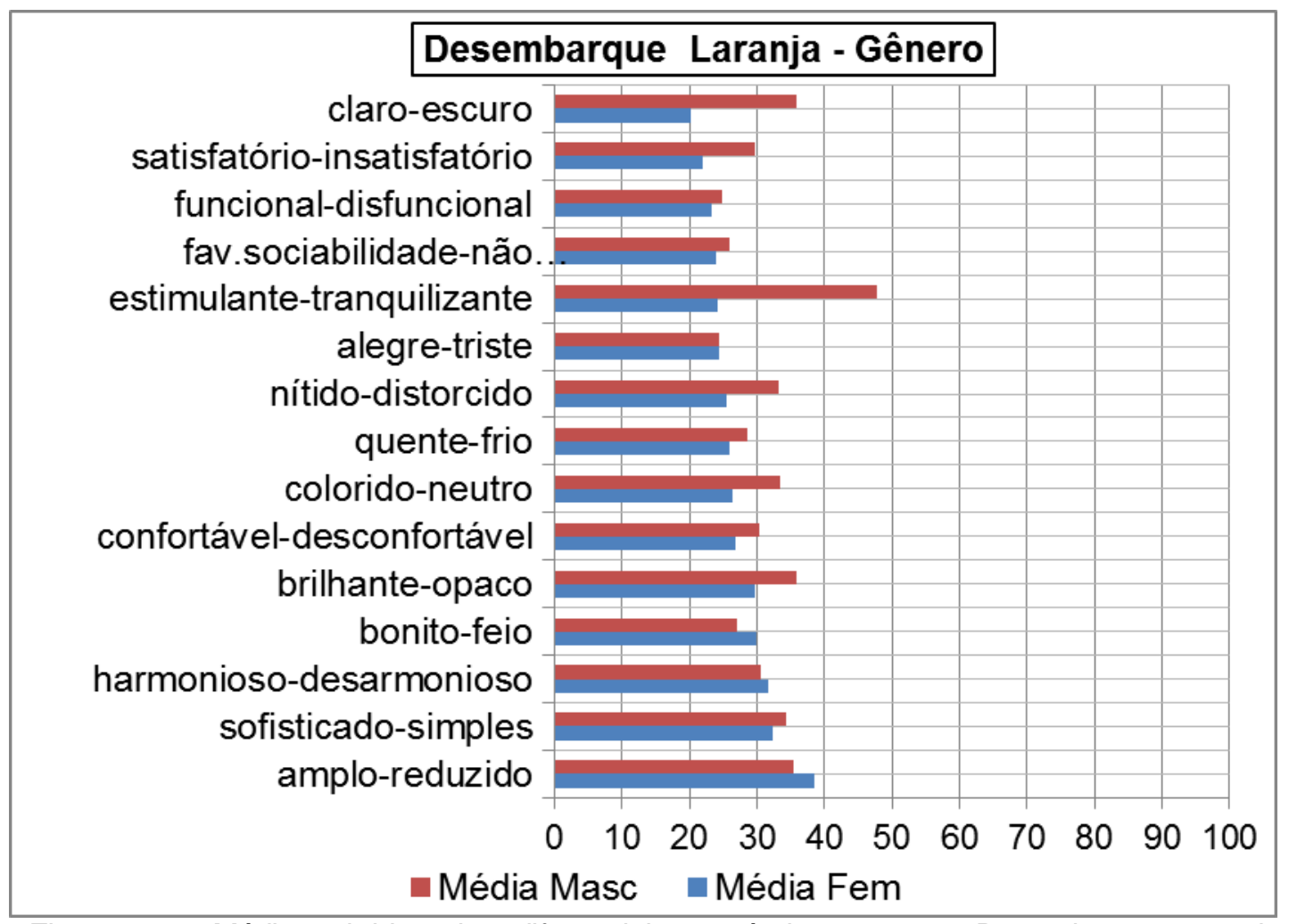

Figura 5.44 Médias obtidas dos diferenciais semânticos para o Desembarque cor da iluminação laranja - Gênero 


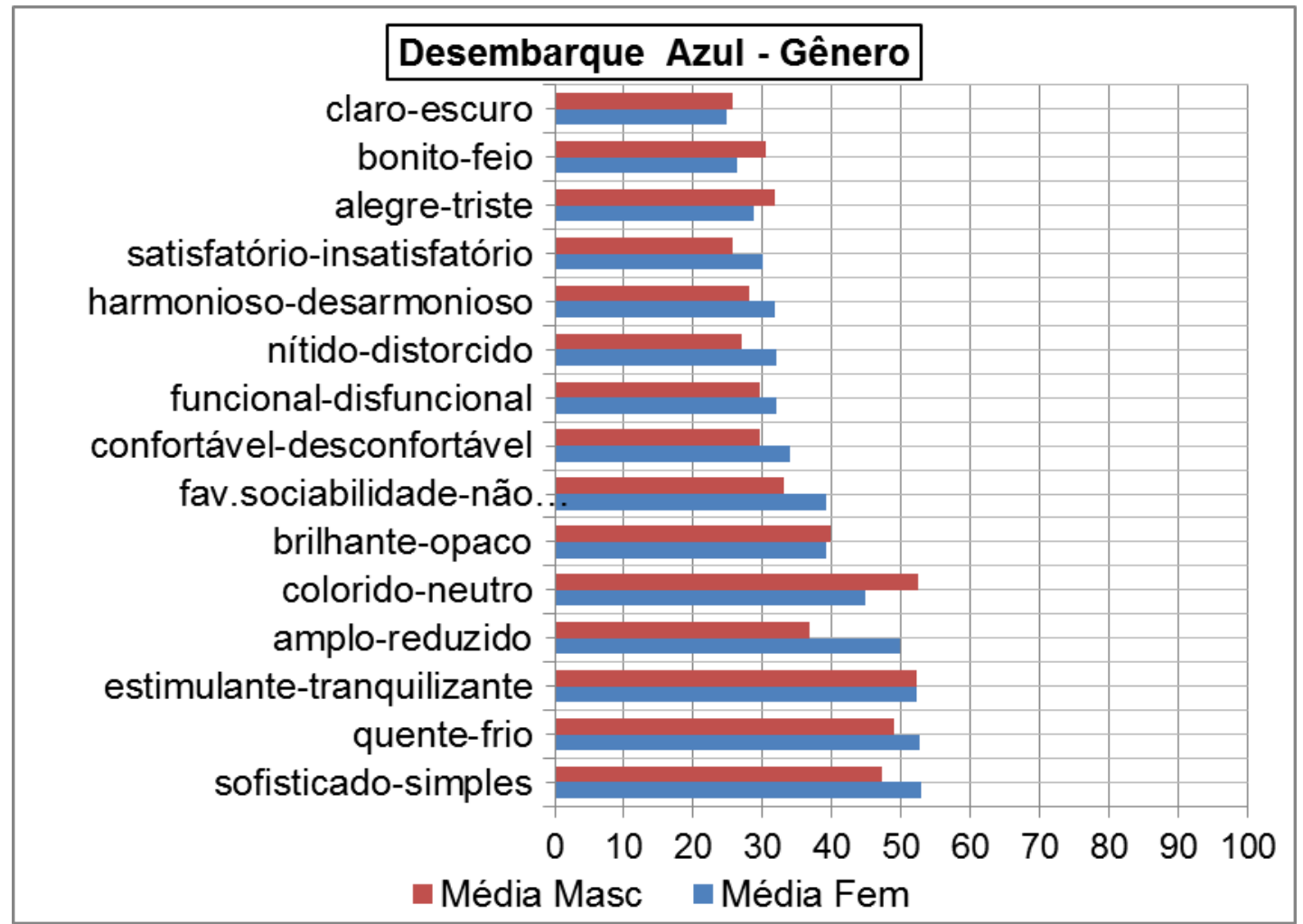

Figura 5.45 Médias obtidas dos diferenciais semânticos para o Desembarque cor da iluminação Azul - Gênero

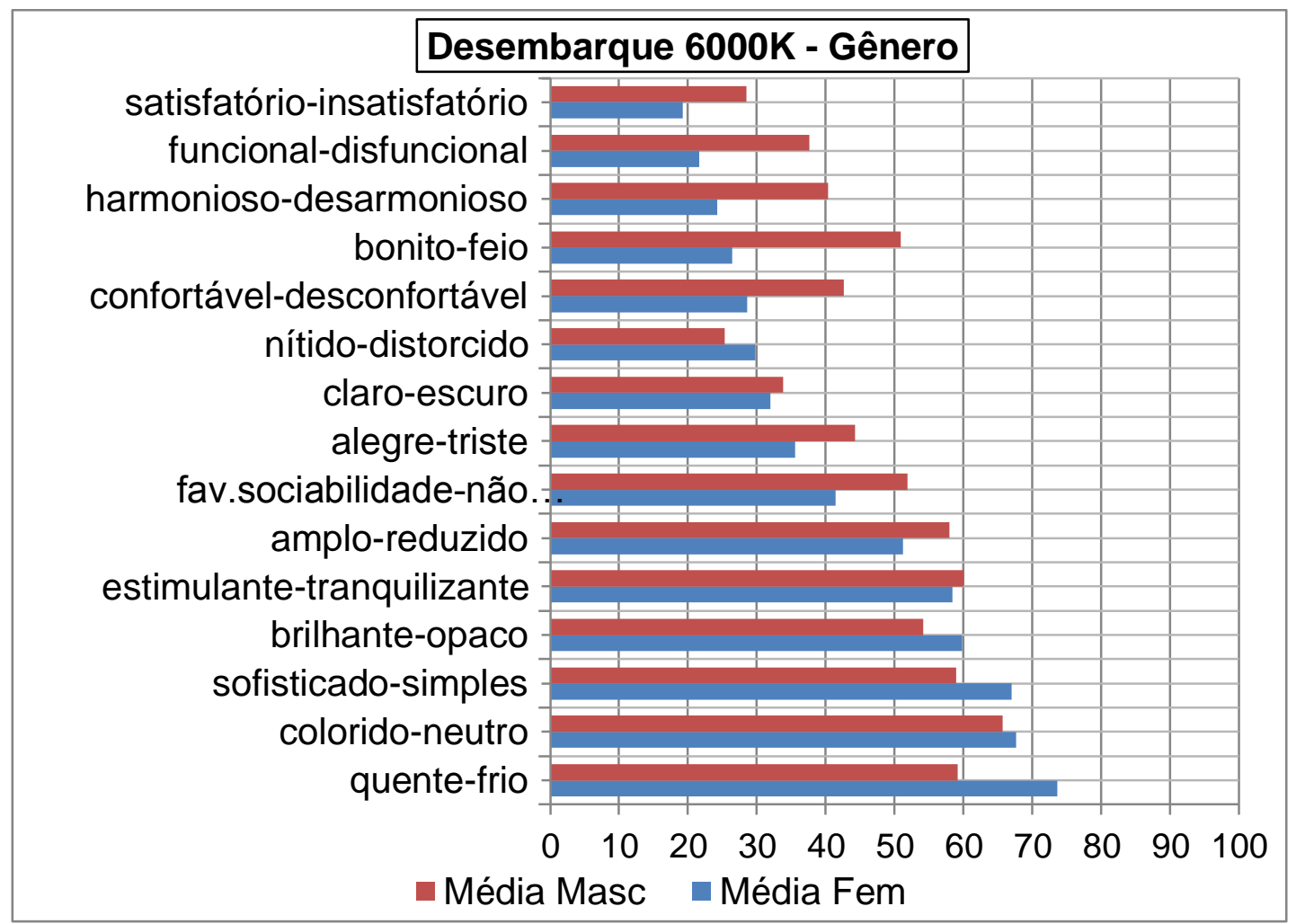

Figura 5.46 Médias obtidas dos diferenciais semânticos para o Desembarque cor da iluminação Branco 6000K - Gênero 


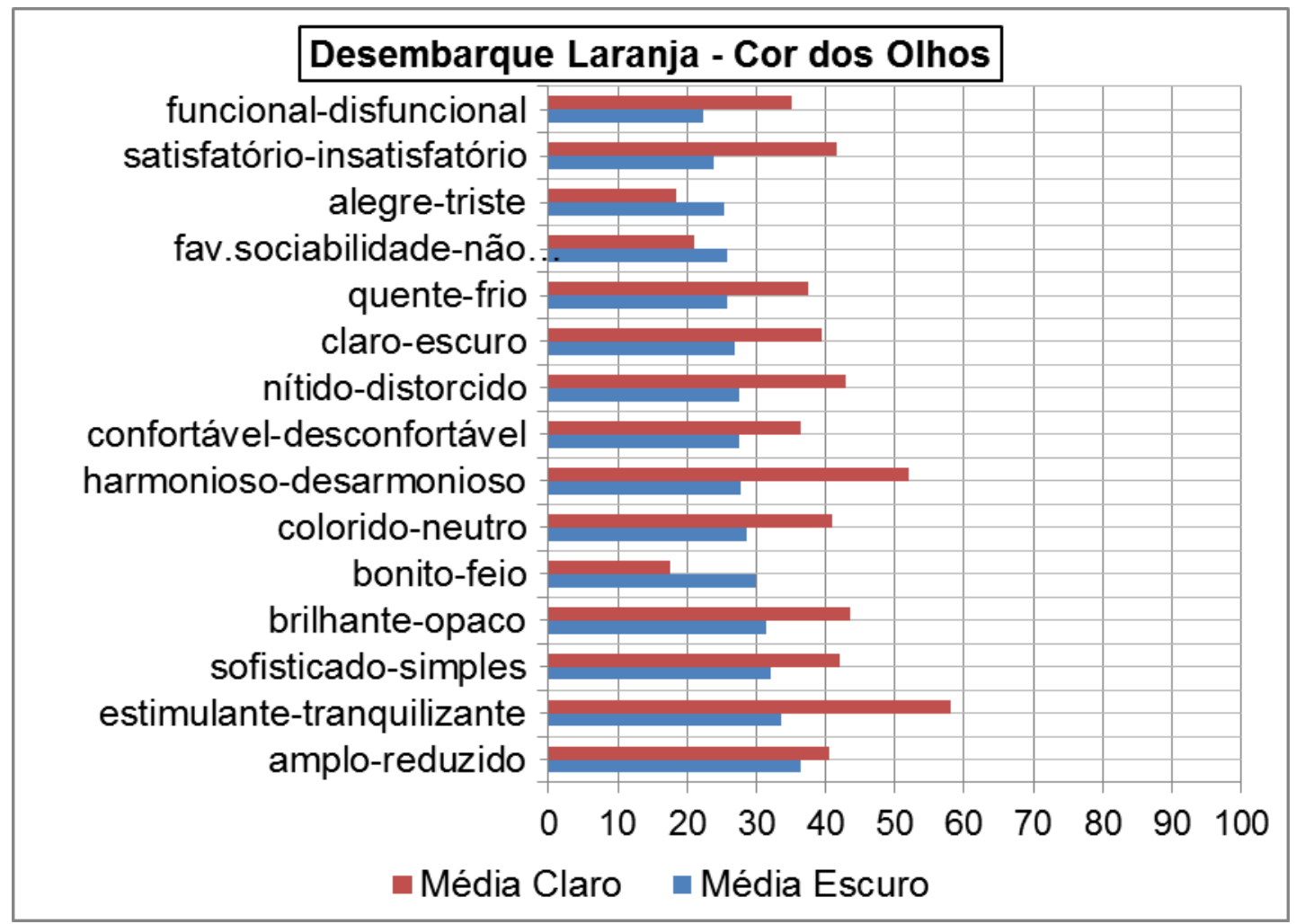

Figura 5.47 Médias obtidas dos diferenciais semânticos para o Desembarque cor da iluminação laranja - Cor dos Olhos

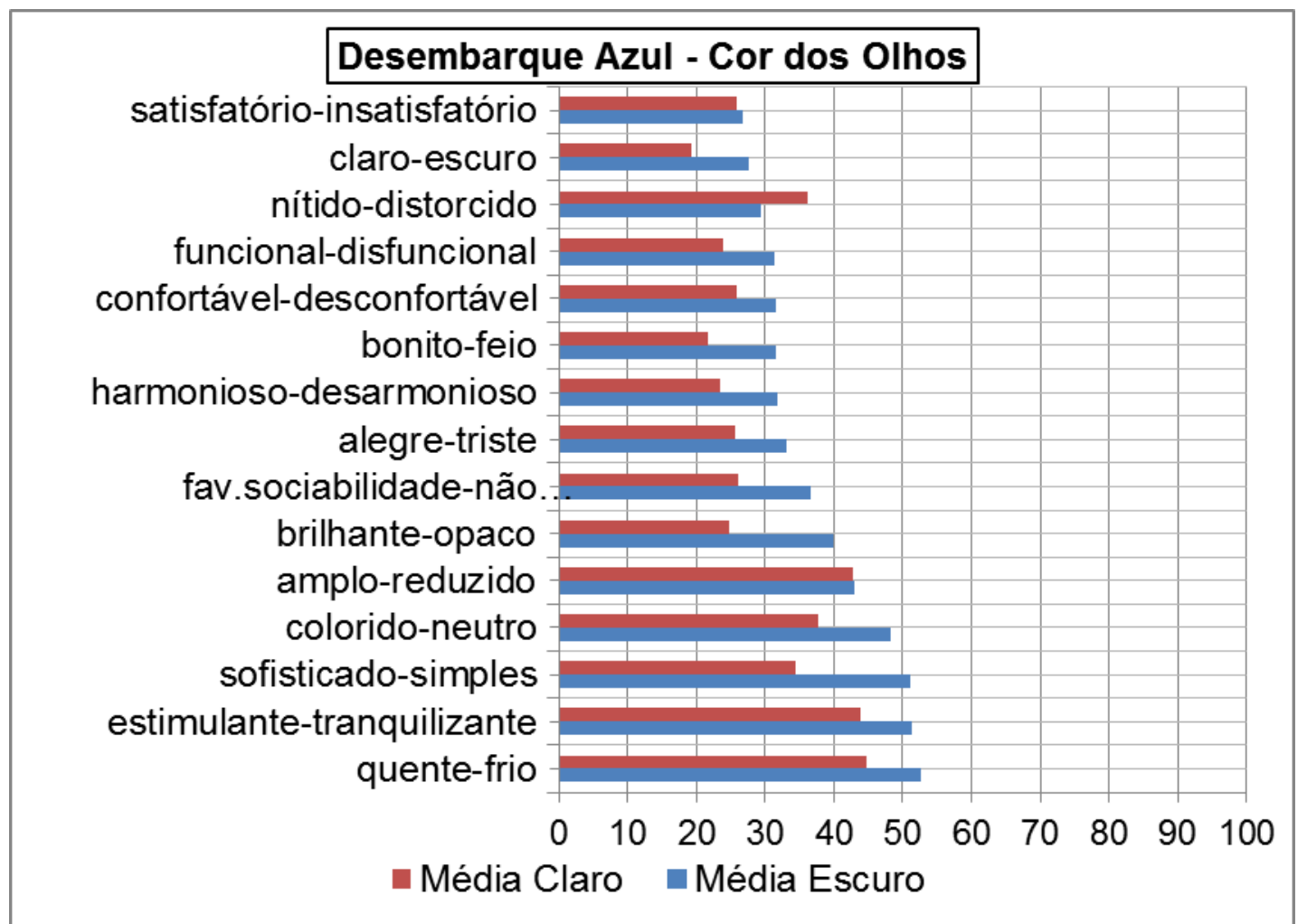

Figura 5.48 Médias obtidas dos diferenciais semânticos para o Desembarque cor da iluminação Azul - Cor dos Olhos 


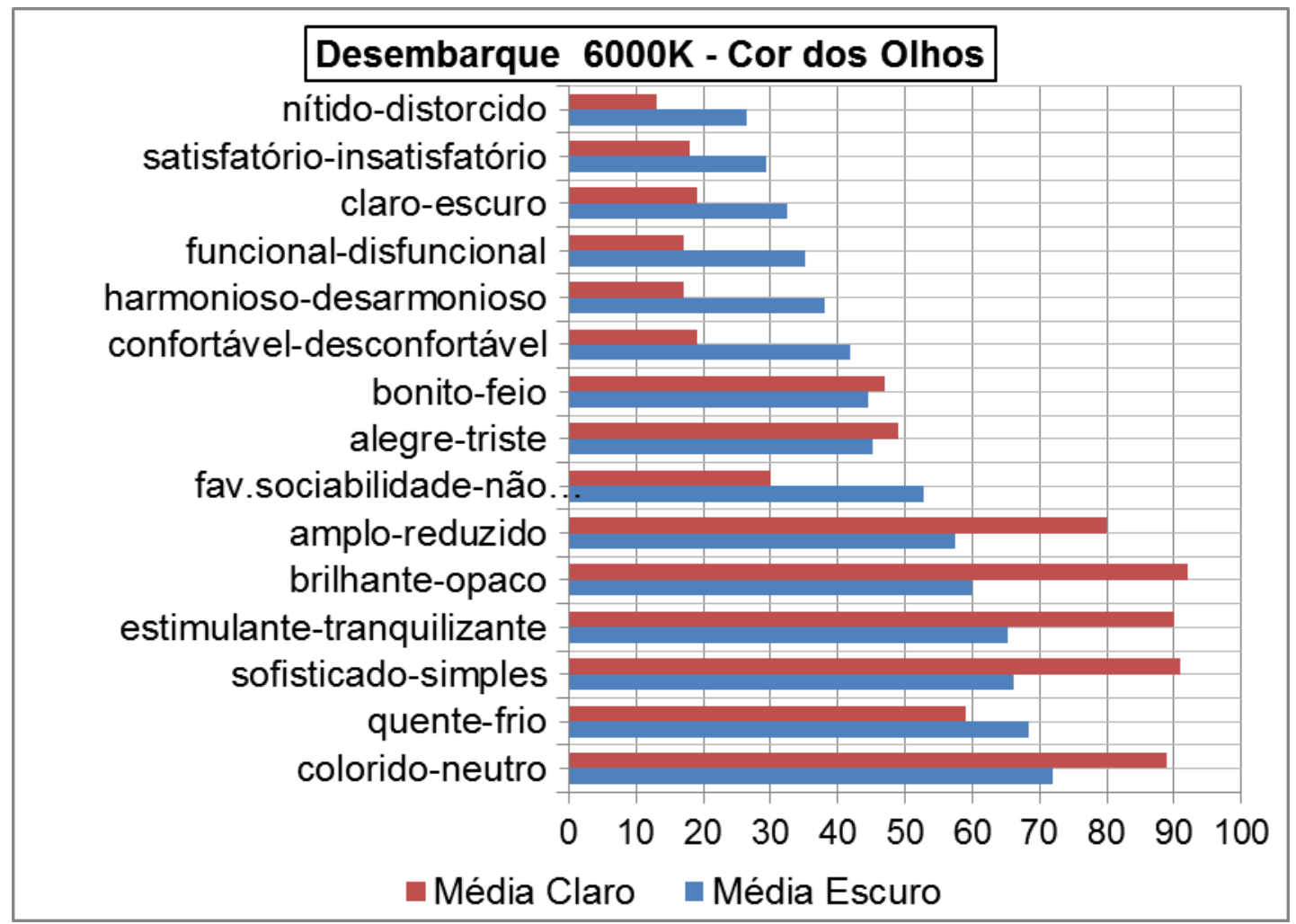

Figura 5.49 Médias obtidas dos diferenciais semânticos para o Desembarque cor da iluminação branco $6000 \mathrm{~K}$ - Cor dos Olhos

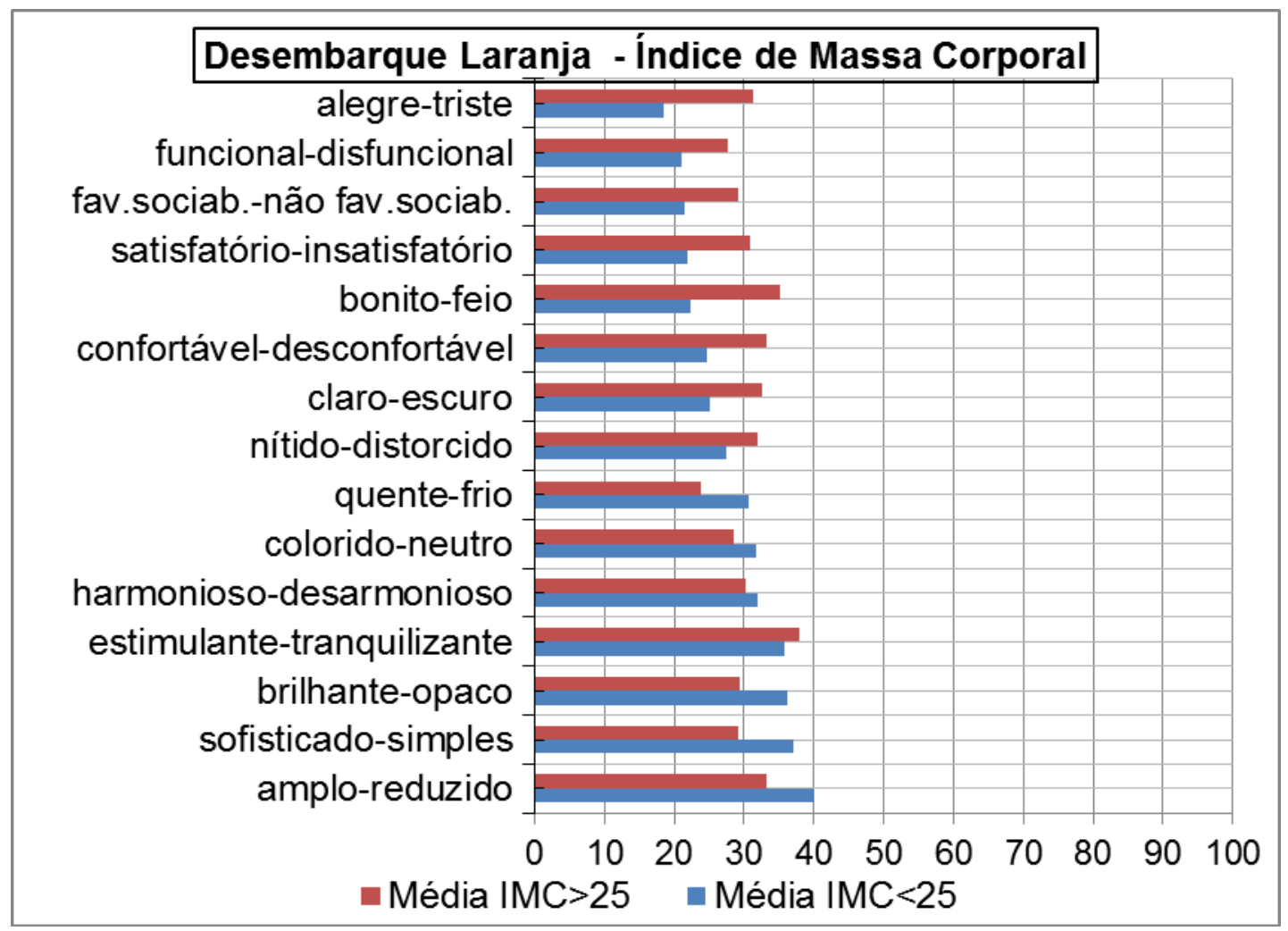

Figura 5.50 Médias obtidas dos diferenciais semânticos para o Desembarque cor da iluminação laranja - Índice de Massa Corporal 


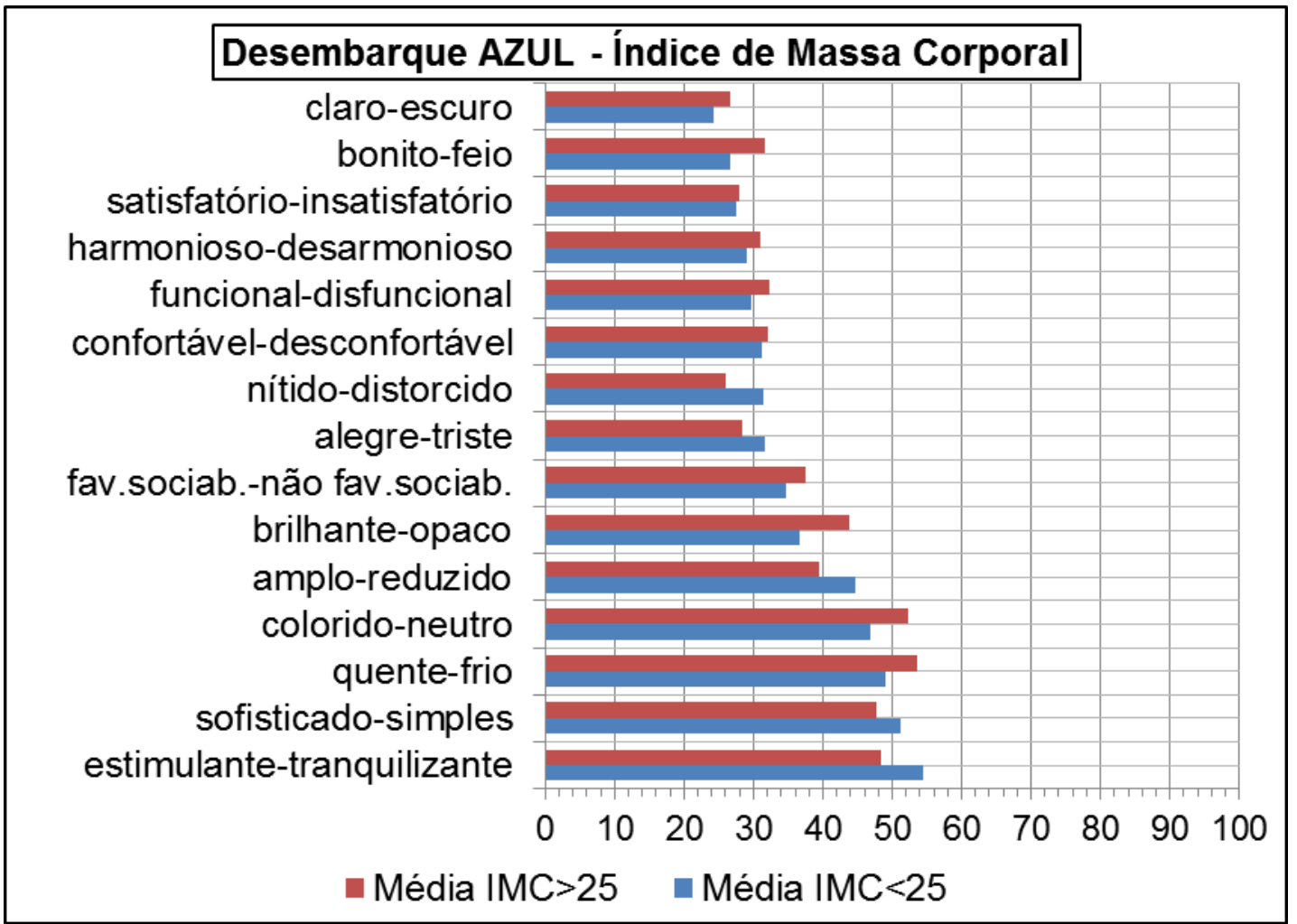

Figura 5.51 Médias obtidas dos diferenciais semânticos para o Desembarque cor da iluminação Azul - Índice de Massa Corporal

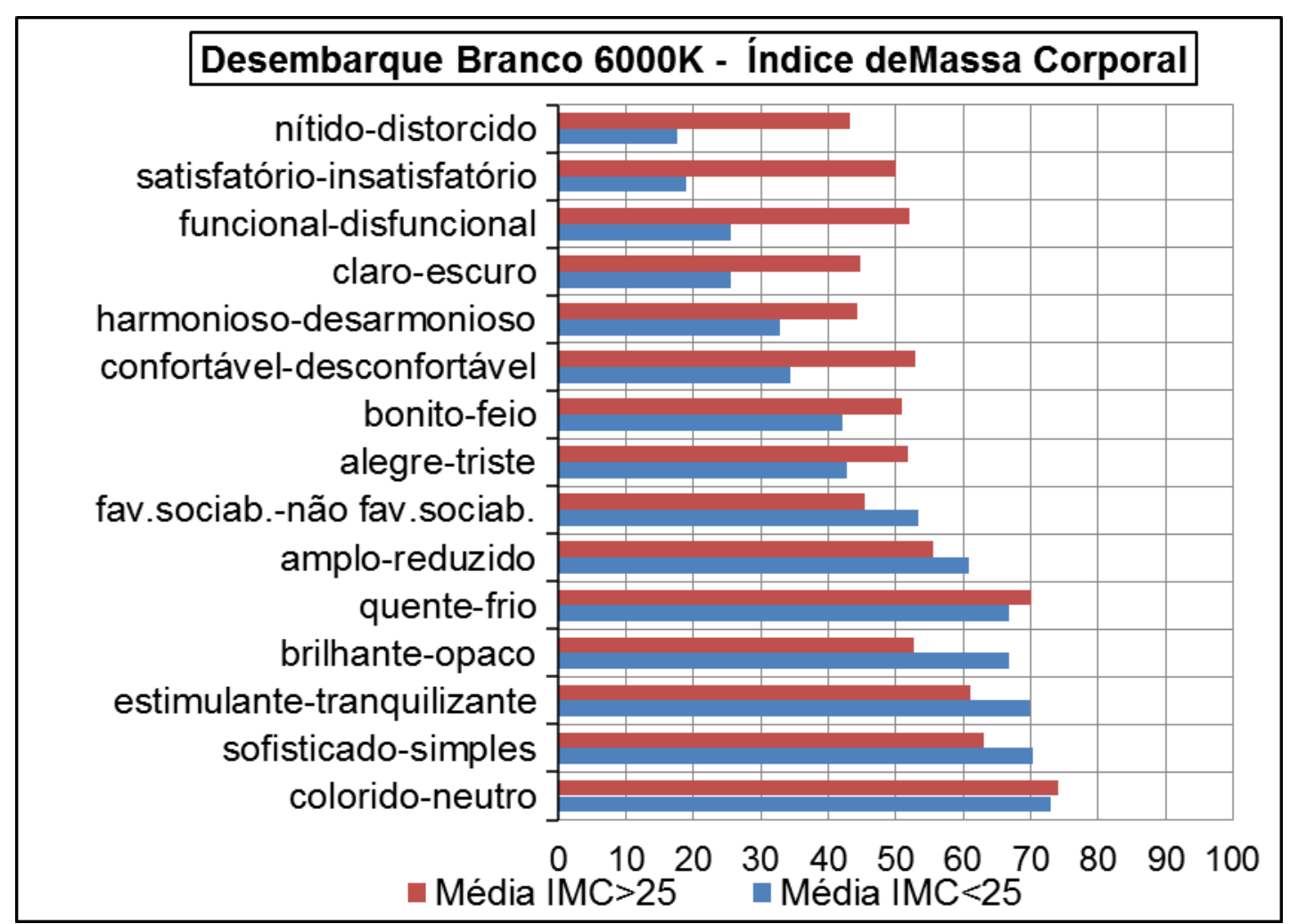

Figura 5.52 Médias obtidas dos diferenciais semânticos para o Desembarque cor da iluminação branco 6000K - Índice de Massa Corporal 
Fazendo-se a média geral e considerando-se todos os ensaios, as pontuações obtidas para os adjetivos bipolares e os desvios padrões são mostradas na Tabela 4.4. Com relação às médias, células na cor amarela apresentam valores menores do 41 pontos, células na cor branca indicam valores entre 40 e 60, células na cor azul apontam valores maiores do 59 pontos.

Tabela 5.4 - Média geral das avaliações e desvio padrão dos adjetivos bipolares. A escala de valores vai de 0 a 100.

\begin{tabular}{|c|c|c|c|c|c|c|c|c|c|c|c|c|c|c|c|c|}
\hline \\
\hline & & 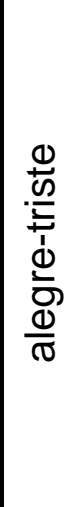 & 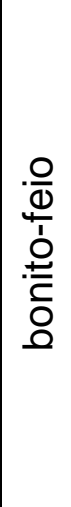 & $\begin{array}{l}0 \\
\\
0 \\
0 \\
0 \\
0 \\
1 \\
0 \\
\frac{1}{\sigma} \\
0\end{array}$ & $\begin{array}{l}\text { 온 } \\
\dot{3} \\
0 \\
\frac{1}{1} \\
\frac{0}{0} \\
\text { 은 } \\
\text { 응 }\end{array}$ & 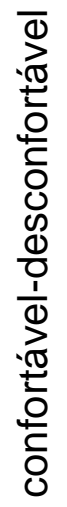 & 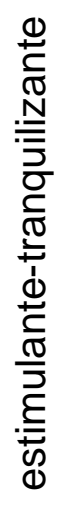 & 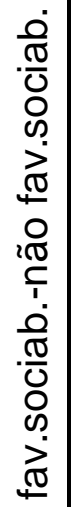 & 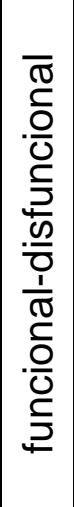 & 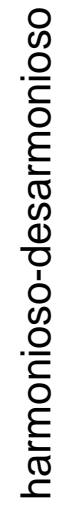 & 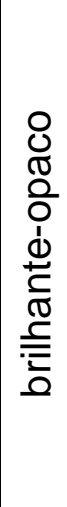 & 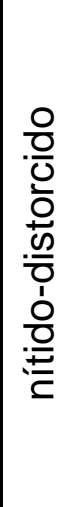 & 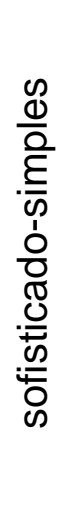 & 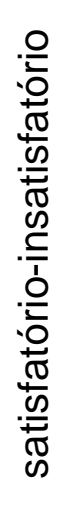 & 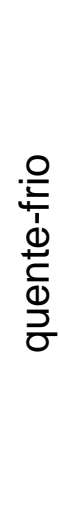 & $\begin{array}{l}\text { 음 } \\
\frac{0}{N} \\
\frac{7}{0} \\
\frac{d}{1} \\
\frac{0}{0} \\
\frac{\mathrm{O}}{\mathrm{D}}\end{array}$ \\
\hline \multirow[b]{2}{*}{ Embarque } & Média & 38 & 30 & 31 & 71 & 31 & 70 & 39 & 27 & 26 & 48 & 27 & 55 & 26 & 51 & 48 \\
\hline & $\begin{array}{l}\text { Desvio } \\
\text { Padrão } \\
\end{array}$ & 21 & 20 & 22 & 26 & 22 & 20 & 24 & 19 & 18 & 26 & 22 & 25 & 21 & 16 & 27 \\
\hline \multirow[b]{2}{*}{ Cruzeiro 1} & Média & 33 & 33 & 33 & 54 & 36 & 59 & 39 & 32 & 32 & 41 & 31 & 49 & 29 & 49 & 46 \\
\hline & $\begin{array}{l}\text { Desvio } \\
\text { Padrão } \\
\end{array}$ & 21 & 24 & 24 & 30 & 23 & 27 & 23 & 21 & 21 & 26 & 23 & 28 & 23 & 19 & 26 \\
\hline \multirow{2}{*}{$\begin{array}{l}\text { Serviço } \\
\text { de Bordo }\end{array}$} & Média & 26 & 29 & 19 & 53 & 27 & 45 & 30 & 25 & 27 & 40 & 21 & 51 & 23 & 43 & 42 \\
\hline & $\begin{array}{l}\text { Desvio } \\
\text { Padrão }\end{array}$ & 20 & 19 & 17 & 29 & 22 & 28 & 22 & 19 & 17 & 26 & 17 & 26 & 19 & 23 & 26 \\
\hline \multirow[b]{2}{*}{ Cruzeiro 2} & Média & 40 & 36 & 42 & 54 & 40 & 58 & 44 & 38 & 36 & 48 & 40 & 43 & 36 & 52 & 51 \\
\hline & $\begin{array}{l}\text { Desvio } \\
\text { Padrão } \\
\end{array}$ & 23 & 22 & 25 & 28 & 27 & 25 & 25 & 24 & 23 & 26 & 24 & 27 & 25 & 21 & 26 \\
\hline \multirow{2}{*}{$\begin{array}{l}\text { Desem- } \\
\text { barque }\end{array}$} & Média & 31 & 31 & 28 & 49 & 32 & 50 & 36 & 30 & 31 & 42 & 30 & 49 & 28 & 48 & 44 \\
\hline & $\begin{array}{l}\text { Desvio } \\
\text { Padrão }\end{array}$ & 21 & 19 & 19 & 26 & 23 & 26 & 22 & 21 & 19 & 25 & 20 & 26 & 22 & 23 & 25 \\
\hline
\end{tabular}

A maior parte das avaliações ficou com valores menores do que 41 pontos, o que implica que os termos do lado esquerdo da Figura 3.5 são mais significativos do que o lado direito, ou seja, pela avaliação dos passageiros a cor da iluminação do interior da cabine deixou o ambiente mais: alegre; bonito; claro; confortável; favorece a sociabilidade; funcional; harmonioso; nítido; satisfatório. Para os pares de adjetivos 
bipolares colorido-neutro, estimulante-tranquilizante, brilhante-opaco, sofisticadosimples, quente-frio, amplo-reduzido não houve tendências nas avaliações.

Pelo fato de que a maioria das médias dos valores pontuados pelos avaliadores ficaram abaixo de 41 pontos, isso significa que as cores utilizadas foram adequadas para a iluminação do interior da aeronave. 


\section{CONSIDERAÇÕES FINAIS}

Um dos objetivos do progresso tecnológico é propiciar conforto aos seres humanos, que traz como resultado a facilidade nas condições de interação entre o homem e o ambiente em que está inserido.

No âmbito de iluminação, uma invenção recente foi a criação de uma fonte luminosa denominada de LED (diodo emissor de luz), a qual fornece um consumo de energia por fluxo luminoso inferior às fontes luminosas convencionais, de maneira mais compacta do que as tradicionalmente utilizadas com baixa geração de calor e com elevada vida útil. Além destes fatores, desenvolveram-se tipos de LEDs com a capacidade de emitir luz conforme as cores primárias vermelha, verde e azul, além do branco quente e branco frio. Com o uso de uma eletrônica adequada, pode-se gerar uma infinidade de cores, é possível alterar a intensidade da luz emitida de cada uma dessas cores básicas. Com o advento dessa tecnologia, aplicou-se essa iluminação no mockup empregado para a realização dos experimentos realizados nesta pesquisa, a fim de se verificar a influência das cores da luz ambiente no conforto de iluminação dos passageiros e, dessa maneira, determinar cores de iluminação que propiciariam uma viagem de avião mais confortável do que atualmente é oferecida pelas empresas aéreas.

Como metodologia, para se coletar as informações dos passageiros relativas à percepção que tinham sob a influência de determinada cor de iluminação e em função da fase do voo, empregou-se o sistema de diferencial semântico, que consiste de avaliação de pares de adjetivos com significados opostos. Nesta pesquisa introduziuse uma sistemática de pontuação diferente da convencional, que é uma escala discreta, com valores que variam de 1 a 7 (OSGOOD p. 85). A escala empregada foi uma linha que separava os pares de adjetivos, com uma determinada dimensão e sem valores explícitos, em que os voluntários (público de passageiros selecionados para esta pesquisa) posicionavam o seu ponto de vista, para determinada característica, por meio de uma marcação quão próxima ou quão distante de um adjetivo, considerado por eles adequado ao que estava sendo questionado. Esta sistemática foi eficaz, pois não induziu os avaliadores a definir valores predeterminados, o que favoreceu uma avaliação reflexiva a respeito da situação e contexto criados. 
Os estudos relacionados à percepção, examinados ao longo deste estudo, determinam a percepção como elemento subjetivo, especialmente quando se trata da percepção de uma cor. Vários são os fatores que influenciam a percepção do ser humano sendo sua influência no estado emocional do ser humano dependente, além de outras caraterística, de raça, cultura, costumes, crenças e gênero. Observou-se nesta pesquisa a comprovação dessa informação, pois pela análise estatística dos dados obtidos, a variação de cada avaliação de pares de adjetivos e nas diversas fases de voo, obteve-se um desvio padrão médio de 20 pontos. Com esse desvio padrão médio, somente valores com pontuações abaixo de 30 ou acima de 70 podem direcionar a avaliação de um par de adjetivos para um determinado adjetivo. Fora dessa faixa seria possível encontrar pessoas que avaliariam um par de adjetivos em qualquer posição da escala empregada. Por exemplo, se uma determinada condição de iluminação for avaliada com o par de adjetivos confortável/desconfortável poder-seia encontrar pessoas que avaliariam a iluminação desde muito confortável até muito desconfortável, evidenciando quão variável é a percepção da qualidade de uma iluminação por parte dos avaliadores. Esse ponto poderia ser estudado com mais profundidade para se compreender o motivo dessa variação, quais os fatores que levam a essa divergência na satisfação que uma iluminação de um ambiente pode trazer.

Em função da análise dos resultados, as cores resultantes na avaliação da iluminação da cabine de aeronave utilizada para este experimento apresentaram coerência com o significado das cores encontrado na bibliografia analisada (LACY, 2007), principalmente para a fase de serviço de bordo onde a luz indicada é em tons quentes e para o Cruzeiro 2 onde a luz com tonalidade azul promove o relaxamento.

Para a fase do voo Embarque a iluminação, a preferência da cor da iluminação foi pelo tom prateado, que está associado às novas tecnologias e à sensação de estabilidade e qualidade. Dessa maneira, há uma tendência do passageiro sentir que está em algo moderno e seguro.

Para a fase do voo Cruzeiro 1 a cor da iluminação obtida foi uma combinação entre a cor turquesa claro, que é uma cor relaxante e repousante, que ajuda a reduzir o estresse e a cor verde claro, que, segundo a literatura estudada, transmite equilíbrio e harmonia, o que leva as pessoas a se sentirem bem consigo mesmas. Nessa fase do 
voo as cores apontadas são adequadas, pois é um momento em que se procura relaxar o passageiro e deixá-lo com a sensação de bem-estar.

Para a fase do voo Serviço de bordo, a cor da iluminação da cabine ficou com um aspecto alaranjado claro, que traz sensação de conforto, alegria, estimula a comunicação, o otimismo e aumenta o apetite. Como nesta fase do voo é um momento de descontração e de alimentação, essa iluminação mostrou-se adequada e coerente com o que se esperava.

Para a fase do voo Cruzeiro 2 a cor da iluminação preferida foi uma combinação de azul, que facilita o relaxamento, a redução do estresse, estimula a interiorização, e roxo, associado a sonho, fantasia, mistério, espiritualidade, podendo gerar sonolência. Nesta fase do voo procura-se fazer com que o passageiro durma ou permaneça em estado contemplativo ou meditativo, portanto a iluminação empregada mostrou-se coerente com a fase do voo.

Para a fase de voo Desembarque a cor da iluminação foi uma combinação da cor turquesa bem clara, que relaxa e reduz o estresse, e da cor prateado, que transmite estabilidade e sucesso. Nesta fase do voo os passageiros devem se sentir bem tranquilos, com a sensação e que tudo correu como o esperado. Portanto, novamente a cor da iluminação foi adequada para essa fase.

Para a pesquisa, procurou-se selecionar um público com diferentes características físicas, dentre elas gênero (masculino-feminino) e a cor dos olhos (claros-escuros) a fim de verificar sua influência no grau de percepção do ambiente. O índice de Massa Corporal não foi fator de seleção, mas também se avaliou a influência desse fator com relação à percepção da qualidade do ambiente em função da cor da iluminação. Com a análise dos resultados, algumas observações devem ser ponderadas:

a) Constatou-se que as características físicas avaliadas tem importância nos resultados da percepção da qualidade do ambiente, sendo que a variação das médias auferidas para cada diferencial semântico é dependente da cor da iluminação e da característica físico do passageiro.

b) Grandes diferenças nos resultados foram observadas com relação à cor do olho, principalmente para uma cor de iluminação branca. 
c) Outra constatação feita foi a variação das médias das avaliações para cada diferencial semântico com relação à localização do passageiro, se sentado ao lado do corredor ou ao lado da janela. Uma pesquisa mais aprofundada poderia levar à conclusão que essa variação de percepção da qualidade do ambiente é em função da assimetria da distribuição da luz no interior da cabine. Não é fácil de se encontrar uma solução técnica para solucionar a assimetria, pois se faz necessário mudanças de localização das fontes de luz e talvez de formato da cabine.

Na literatura estudada observou-se que a sensação de conforto está relacionada com o individual e não com o padronizado. O indivíduo para se sentir relaxado, livre, tranquilo - sinônimos de conforto coletados durante o estudo - é necessário que ele tenha liberdade de fazer suas próprias escolhas, que levam em conta suas necessidades, suas experiências e sensações passadas, sua memória perceptiva, sua cultura e sua história de vida. Seria importante se fosse permitida a "POSSIBILIDADE DE” se criar um ambiente personalizado, se assim for desejado.

Esse seria o ideal do conforto a ser considerado em qualquer projeto de bem-estar humano em seus diversos aspectos tais como espiritual, moral, físico ou sensorial.

Esse mesmo ideal vale também para qualquer relação entre oferta e procura em que o serviço oferecido necessita do cliente a fim de que a transação seja finalizada. Para isso, a satisfação, cuja característica implica em personalização, especificidade, originalidade, necessidade, é quesito fundamental. Vê-se, dessa maneira, que conforto e padronização, na maior parte das situações, não dialogam.

Entretanto, em qualquer projeto, também há dependência de outras questões tais como: viabilidade técnica, investimentos, custos, estado da arte, concepção. Estamos em um mundo em transformação e certamente, no futuro esses fatores poderão ser alterados e não serão impeditivos para a execução de determinado projeto que em algum momento no passado foi inviável.

Esta pesquisa, como várias outras existentes, teve restrições relacionadas ao tempo necessário para o término do experimento. Questões de viabilidade econômica, entre outras. No entanto, todo e qualquer experimento vale para futuras discussões e estudos em que as circunstâncias possibilitarão novos resultados. 
Há ainda o aspecto relacionado ao objeto estudado que ocorreu em um espaço coletivo - a cabine do avião. O local, embora tenha assentos específicos para os passageiros, não possui espaços individuais, concebidos dentro de um espaço coletivo, exclusivos para cada passageiro, de modo que ele possa criar sua própria ambientação, o que, neste momento da história, inviabiliza a concretização do sentido profundo de conforto, no aspecto holístico, em que o corpo é uma extensão do ambiente em que está e vice-versa.

Deve-se destacar que o resultado encontrado nessa pesquisa é válido para a população avaliada, para as dimensões do mockup utilizado, para a localização das fontes luminosas e acabamentos do interior da cabine. Portanto, para um estudo mais abrangente, deve-se avaliar a influência desses fatores na percepção do conforto de iluminação em uma cabine de aeronave, ou seja, a influência da intensidade luminosa empregada, a influência da combinação/tipo de acabamento no interior da cabine, a influência do posicionamento das fontes luminosa, a influência da característica físicas dos indivíduos, a influência das dimensões da cabine, a influência do estado emocional do passageiro precisam ser consideradas para que uma real situação de conforto seja instalada.

Para trabalhos futuros, pode ser feito um estudo para correlacionar os resultados obtidos nesta pesquisa em função da cor da luz, a das características dos objetos e transpor essa informação para determinar qual o espectro da luz que deverá ser aplicado quando se muda as cores dos objetos; Também se podem estudar com maior profundidade os efeitos da não homogeneidade da distribuição da luz na cabine; pode-se verificar os aspectos relacionados com a etnia, religião, cultura dos passageiros. Ao determinar a influência das cores de iluminação que deixam as pessoas confortáveis/desconfortáveis, podem-se definir características de iluminação que diminuam o estresse de uma viagem, tornando-a mais agradável.

Além da possibilidade prática de aplicação em cabines de aeronaves, o resultado desta pesquisa poderá ser estendido para outros ambientes fechados, onde o desconforto causado pela cor da iluminação aplicada em tais ambientes possa ser considerado importante na execução de tarefas que exigem iluminação adequada. 


\section{REFERÊNCIAS BIBLIOGRÁFICAS}

ABS, American Bureau of Shipping, www.eagle.org

ABS, Guide for Passenger Comfort on Ships, December 2001.

American Standards of Heating, Refrigerating and Air-Conditioning Engineers (ASHRAE) ASHRAE Handbook: Fundamentals, Atlanta: Inch-Pound Edition. 2009).

ANSI/ASHRAE. Standard 55-2010. Thermal Environmental Conditions for Human Occupancy, Atlanta: ASHRAE, 2010

BODUCH, Michael; FINCHER, Warren. Standards of Human Comfort: Relative and Absolute. UTSoA - Meadows Seminar Fal 2009 The University of Texas at Austin, School of Architecture (CSD center for Sustainable Development) (p. 1-10)

BOENTE, Alfredo; BRAGA, Glaucia. Metodologia Científica Contemporânea para universitários e pesquisadores. Rio de Janeiro: Brasport Livros e Multimídia Ltda, 2004

BOMMEL, W. J. M.; BELD, G. J. Lighting for work: visual and biological effects; Philips Lighting, Netherlands, 04/2004

BROEGA, Ana Cristina da Luz. Contribuição para a Definição de Padrões de Conforto de Tecidos Finos de Lã. Universidade do Minho, Escola de Engenharia. Tese de Doutorado - ramo de Física Têxtil (2007).

BRUSATIN, Manlio. Historia de los Colores.Barcelona: Ediciones Paidós Ibérica S.A, 1987

CIE Publication 17.4-1 987 International Lighting Vocabulary

CIPELLI, Antonio M.;MARKUS, Otávio; SANDRINI, Waldir. Teoria e Desenvolvimento de Projetos de Circuitos Eletrônicos, ed. Érica, 2009.

CLEAR, Robert D. Discomfort Glare: What Do We Actually Know? Published in Lighting Research and Technology Journal, April 2012),

COELHO, Denis. A Growing Concept of Ergonomics Including Comfort, Pleasure and Cognitive Engineering: An Engineering Design Perspective. Tese de Doutorado, (Department of Electromechanical Engineering School of Engineering Sciences) Portugal: Universidade da Beira Interior, 2002

CRICK, H. C. Francis. A Hipótese Espantosa: Busca científica da alma, Lisboa, Portugal: Instituto Piaget, 1998

DANCEY, Christine P.; REIDY, John. Estatística sem Matemática para Psicologia Porto Alegre, 3ed, 2007. 
DAVIES, Alex. Acoustic Trauma: Bioeffects of Sound. University of New South Wales, 1999

DIN EN 12464-1 Lighting of work places, Part 1 Indoor work places, 2003

DERLOFSKE, J. V.; BULLOUGH, J. What is Glare? NHTSA Workshop Estados Unidos da América, 2004.

DUARTE, Francisco. O sentido dos sentidos: a educação (do) sensível. PR: Criar Edições Ltda, 2010.

FARINA, Modesto; PEREZ, Clotilde; BASTOS, Dorinhos. Psicodinâmica das cores em comunicação. 5a ed. SP: Edgard, 2006

FÈRE, Charles S. Sensation et Mouvement, Felix Alcan, Paris, 1887.

FLOR, Damaris E.; CARVALHO, Terezinha A. P. E. Neurociência para Educador: coletânea de subsídios para "alfabetização neurocientífica". Baraúna, 2012.

FLYNN, J. E.; SPENCER, T. J.; MARTYNIUK, O.; HENDRICK, C.

A Guide to methodology procedures for measuring subjective impressions in lighting. Journal of IES, January 1979

FLYNN, J. E.; SPENCER; T. J.; MARTYNIUK; O.; HENDRICK, C.

Interim Study of Procedures for Investigating the Effect of Light on Impression and Behavior. Journal of IES, October, 1973

GANSLANDT, R.; HOFMANN, H. Handbook of Lighting Design. Braunschweig /Alemanha: ERCO Leuchten $\mathrm{GmbH}, 1992$.

GRANDJEAN, Etienne. Manual de Ergonomia: adaptando o trabalho homem. Porto Alegre: Artes Médicas, 1998.

GRONDZIK, W. et al. Mechanical and Electrical Equipment for Buildings. (Wiley, 2010) BBS pag741.

HENRIQUE, Luís L. Acústica Musical. 3ed, Lisboa: Fundação Calouste Gulbenkian, 2009.

IESNA - Illuminating Engineering Society of North America. The IESNA Lighting Handbook. Nova lorque, EUA: IESNA departamento de publicações, 2000.

INKAROJRIT, V. Balancing Comfort: Occupants' Control of Window Blinds in Private Offices. Tese de doutorado de filosofia, University of California, Berkeley; Fall 2005

ITTEN, Johannes. Elements of Color. NY: Van Nostrand Reinhold Company, 1970.

JARGON, Julie. At Starbucks, It's Back to the Grind, Wall Street Journal 17 June, 2009. 
JORDAN, Patrick. Human factors for pleasure in product use. Applied Ergonomics. V.29, n.1, p. 25-33, 1998

HELLER, Eva. Psicologia De/ colar Cómo actúan los colores sobre los sentimientos y la razón. Barcelona : GG, 2004.

LACY, Marie Louise. O Poder das Cores, $4^{a}$ ed. Pensamento-Cultrix Ltda, São Paulo, 2007.

LENT, Roberto. Cem Bilhões de Neurônios: conceitos fundamentais de neurociência. SP:Atheneu, 2010. 2a. ed.

LINDEN, Júlio Carlos de Souza van der. Um modelo descritivo da Percepção de conforto e de risco em calçados femininos. Tese de Doutorado (Doutorado em Engenharia de Produção). Porto Alegre, Universidade Federal do Rio Grande do Sul, 2004.

LUEDER, R. K. Seat Comfort: A Review of the Construct in the Office Environment. Human Factors: The Journal of the Human Factors and Ergonomics Society, V.29, p. 701-711, 1983.

LÜSCHER, Max. O teste das cores. Rio de Janeiro: Renes, 1980.Nao tenho ainda

MALDONADO, Tomas. The Idea of Comfort. Design Issues, v. 8, N.1 (Autumn, 1991), p. 35-43. Published by: The MIT Press.

McCAFFERTY, D. B.; McSWEENEY, K. P. Comfort: Passengers, Crews and Fast Ferries. Fast Ferries International 2001, New Orleans, LA, March 2001.

MALVINO, A.P. Eletrônica, vol.1, 4ª . ed. Pearson Makron Books, São Paulo,2006.

MERLEAU-PONTY, M. Fenomenologia da percepção. Trad. Reginaldo de Piero $1^{\underline{a}}$ ed., Freitas Bastos, São Paulo, 1971.

MEYER, P. O Olho e o Cérebro: Biofilosofia da percepção visual. Editora UNESP, São Paulo, 2002

NEWSHAM, Guy R.; VEITCH, Jennifer A.; ARSENAULT, Chanta D.I; DUVAL, Cara L. Effect of dimming control on office worker satisfaction and performance. Institute for Research in Construction, M24 National Research Council Canada, Ottawa, ON, NRCC-47069, 2004

NBR 7195. Cores para a segurança. Junho de 1995

NBR 16401-2. Instalações de ar-condicionado - Sistemas centrais e unitários.

Part 2: Parâmetros de conforto térmico. ABNT, RJ, 2008

NISHITANI, K. The Power of Colors-Visual Perception and Comfort Kinki Sharyo KS World 2006 vol. 13 
OSGOOD, C. E.; SUCI, G. J.; TANNENBAUM, P. H. The Measurement of Meaning. University of Illinois, 9th edition, 1975

PINEAU, Claude. The psychological meaning of comfort. International Review of Applied Psychology, v. 31, p. 271-283, 1982.

PEZEU-MASSABUAU, Jacques. A Philosophy of Discomfort. London: Reaction Book, 2012.

QUEHL, Julia. Comfort studies on aircraft interior sound and vibration, Carl von Ossietzky Universitat, Oldenburg, 2001.

ROSET, J. et al. Learning About Humidity in Thermal Comfort, Universitat Politecnica de Cataluyna. Disponível em <http://www-fa.upc. es/personals/jroset/esun058. html>. Acesso em 29 de Junho de 2013.

RUSS, John C. Image Processing Handbook, 6e, Florida, CRC Press, 2011

SAGAWA, K.; TAKIZAWA, S.; SAITO, T.; DOI, T. Scaling of comfort for a colored scene and development of a colour comfort meter. ISCC/CIE Expert Symposium, Ottawa, ON,16-17 May, 2006

SALAZAR, M.; CHIARINI, M. Yoga da Voz, Tahya Edições, São Paulo, 2007

SALVENDY, G. Handbook of human factors and ergonomics, 2nd ed. Copyright (C) 1997. Reprinted by permission of John Wiley \& Sons, Inc

SLATER, K. Human Comfort, Charles C. Thomas, Springfield, Illinois, 1985

SLATER, K. Discussion Paper The Assessment Of Comfort, The Journal of The Textile Institute, 77:3, 157-171, Londres, 1986

SANDERS, M.S., McCORMICK, E.J. Human Factors in Engineering and Design. New York: McGraw Hill,1993.

STEIN, Benjamin. et al. Mechanical and Electrical Equipment for Buildings ,11e. New Jersey: John Wiley and Sons, 2010.

TILLER, Dale et al. Combined Effects of Noise and Temperature on Human Comfort and Performance (1128-RP) USA: Architectural Engineering University of Nebraska-Lincoln, 2010.

TUNNACLIFFE, Alan H. Introduction to Visual Optics; Association of British Dispensing Opticians, 1993, p. 299-329

VEITCH, Jennifer A.; NEWSHAM, Guy R. Lighting Quality and Energy-Efficiency Effects on Task Performance, Mood, Health, Satisfaction and Comfort Institute for Research in Construction, M24 National Research Council Canada, Ottawa, ON, IESNA 1997 Conference 
VERGARA, Sylvia Constant. Projetos e Relatórios de Pesquisa em Administração. São Paulo: Editora Atlas, 2004. 5ª Ed.

WAITE, John. Old and New Office Appearance. CIBSE - The Chartered Institution of Building Services Engineers 2001 National Conference, London

VIGOUROUX, Roger. A Fábrica do Belo, DinaLivro, Lisboa, Portugal, 1992

YAMADA, S.; PRICE, H.E.S. The Human Technology Project in Japan Proceedings of Human Factors Society 35th Annual Meeting, p. 1194, 1991.

ZHANG, Lijian. Multi-dimensional approach for sitting comfort assessment. Dissertation submitted tothe Department of Industrial Engineering Program and the Faculty of the Graduate School of the State University of New York at Buffalo. Buffalo, New York, 1992. 


\section{APÊNDICE A - Tecnologia do LED}

LED (Light-Emitting Diode, Diodo Emissor de Luz) é um diodo semicondutor ou um dispositivo eletrônico em que a corrente passa em uma única direção. Basicamente o diodo é composto por dois semicondutores, um Tipo $N$ (dopado com cargas negativas) e outro tipo $P$ (contendo lacunas ou falta de elétrons). A junção esses dois tipos de semicondutores transforma-se em um cristal único (junção na qual é mantida a continuidade da estrutura cristalina), denominado de junção PN ou diodo de junção (CIPELLi et al., 2009, p. 9). Pela aplicação de uma diferença de potencial elétrico entre os semicondutores $\mathrm{P}$ e $\mathrm{N}$, ocorre uma difusão. Os elétrons e as lacunas se deslocam e se recombinam em uma região denominada de camada de depleção. Cada vez que um elétron se difunde na junção, gera-se um par de íons denominado de dipolo. Esses dipolos são retidos nas extremidades do cristal PN por causa das ligações covalentes, deixam a região de junção dos semicondutores $P$ e $N$ vazia e criam a camada de depleção (MALVINO, 2006, p. 38). Essa característica está exemplificada pela Figura A.1.

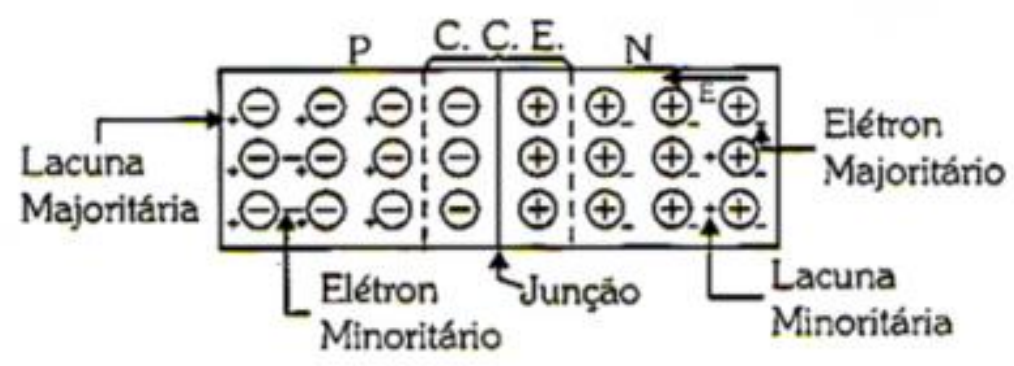

๑ : íon positivo da impureza pentavalente

$\Theta$ : íon negativo da impureza trivalente

+ : lacuna

- : elétron

C.C.E. : camada de carga espacial ou camada de depleção

E : campo elétrico originado pelos íons da rede cristalina

Figura A.1 Representação de uma junção PN não polarizada (CIPELLI et al. 2009, p.10).

Em um LED a recombinação dos elétrons/lacunas na camada de depleção gera energia na forma de radiação visível, pela mudança de órbita dos elétrons do átomo do semicondutor, como exemplificado na Figura A.2. Dependendo dos elementos que 
compõe os diodos, tais como gálio, arsênico, Índio, fósforo, podem-se produzir diferentes irradiações luminosas, sendo as mais comuns nas cores vermelho, azul verde, amarelo, branco (MALVINO, 2006, p. 161).

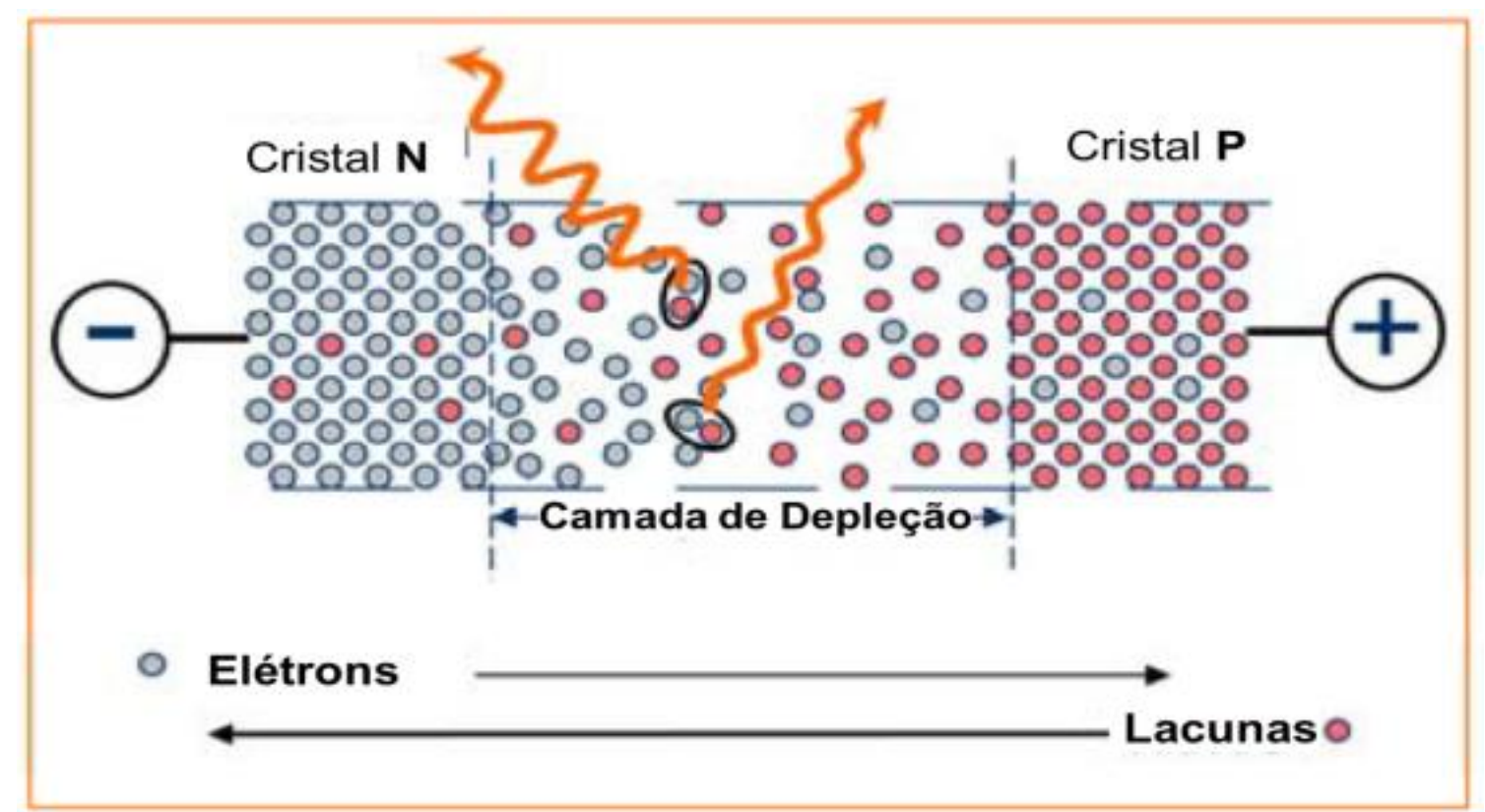

Figura A.2 Emissão de radiação na recombinação do elétron na camada de depleção.

A cor da luz é determinada pelo seu comprimento de onda, ou sua energia. A energia emitida por um fóton de um LED é proporcional à mudança de órbita do elétron. Quando o átomo é excitado por uma corrente elétrica ele absorve energia e o elétron é impulsionado para um orbital mais alto, ou seja, mais afastado do núcleo. Quando o elétron retorna para sua posição original ele libera energia na forma de fóton que, em alguns casos, poder ser um fóton luminoso.

$\mathrm{Na}$ condição sem excitação os semicondutores não conduzem eletricidade e todos os elétrons estão na banda de valência. Ao se aplicar energia suficiente para que elétrons passem para a banda de condução, energia denominada de gap de energia ou banda proibida, o semicondutor passa a ser condutor e emite luz. A Figura A.3 mostra as energias proibidas em função do parâmetro de rede, que está relacionado com as dimensões do cristal, de dois materiais semicondutores muito usados em LEDs, o InGaN (Nitreto de Índio e Gálio) usado para as cores violeta azul e verde, e o InGaAIP (Fosfeto de Índio, Gálio e Alumínio) usado para o verde, amarelo, laranja e vermelho. 


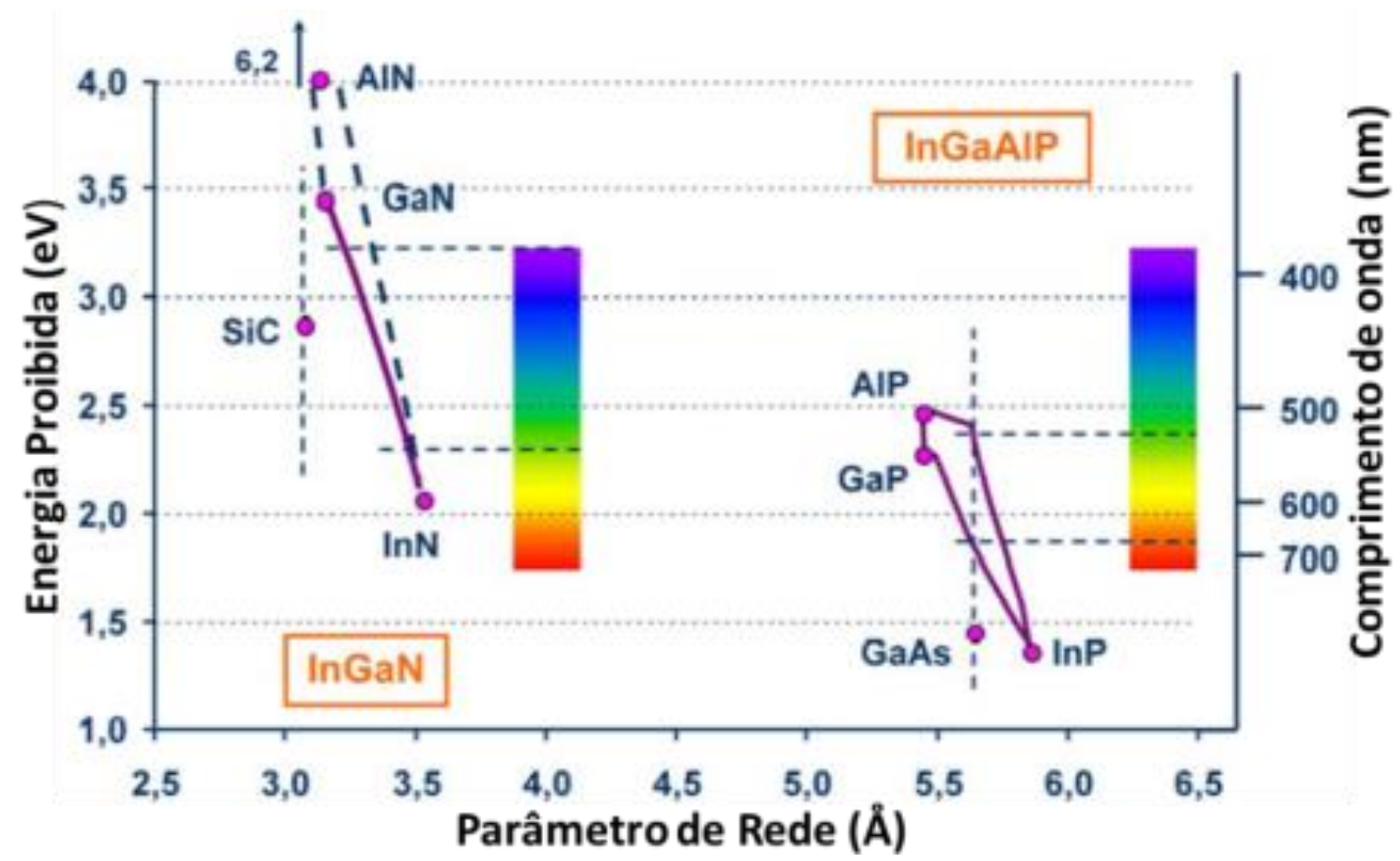

Figura A.3 Relação entre energia proibida, parâmetro de rede e comprimento de onda para dois tipos de materiais empregados nos LEDs (Vertamatti baseado em LED Basis, 2010, OS SJ AE, RS, OSRAM).

Existem vários tipos de empacotamentos de LEDs, com patentes distintas. A Figura A.4 exemplifica uma construção típica de um LED tipo SMD (Surface Mount Device, Dispositivo de Montagem em Superfície), com a fixação por solda do LED sobre uma superfície. A armação condutora atua como dissipadora do calor gerado pelo chip semicondutor e como meio de condução da corrente e fixação do LED no circuito impresso. Um fio de conexão em ouro é usado para conectar o topo do chip com a armação condutora. A cavidade é preenchida com resina epóxi que dá rigidez ao sistema e serve como refletor da luz emitida pelo diodo.

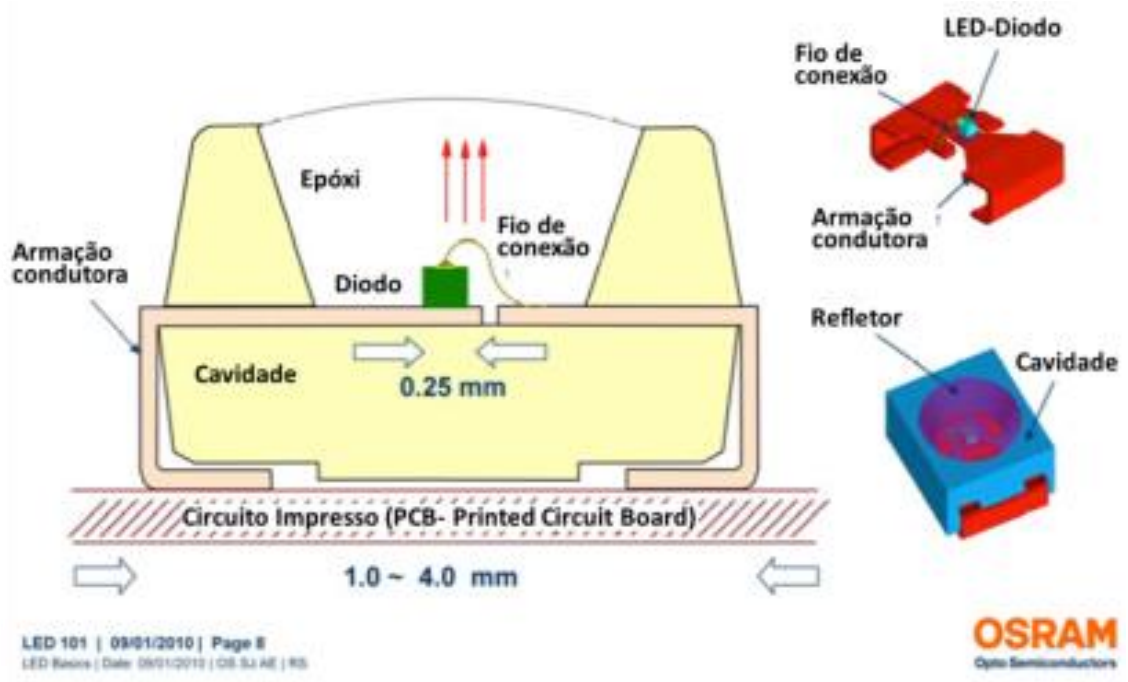

Figura A.4 Estrutura simplificada de um LED 
A característica do LED é emitir uma luz monocromática, exceto os LEDs brancos que possuem outro processo de geração de cor por meio de camada de Fósforo a qual reage com a luz emitida pelo diodo, nesse caso localizada na faixa do ultravioleta. A Figura A.5 ilustra a distribuição espectral com relação à intensidade relativa da radiação do LED para algumas cores.

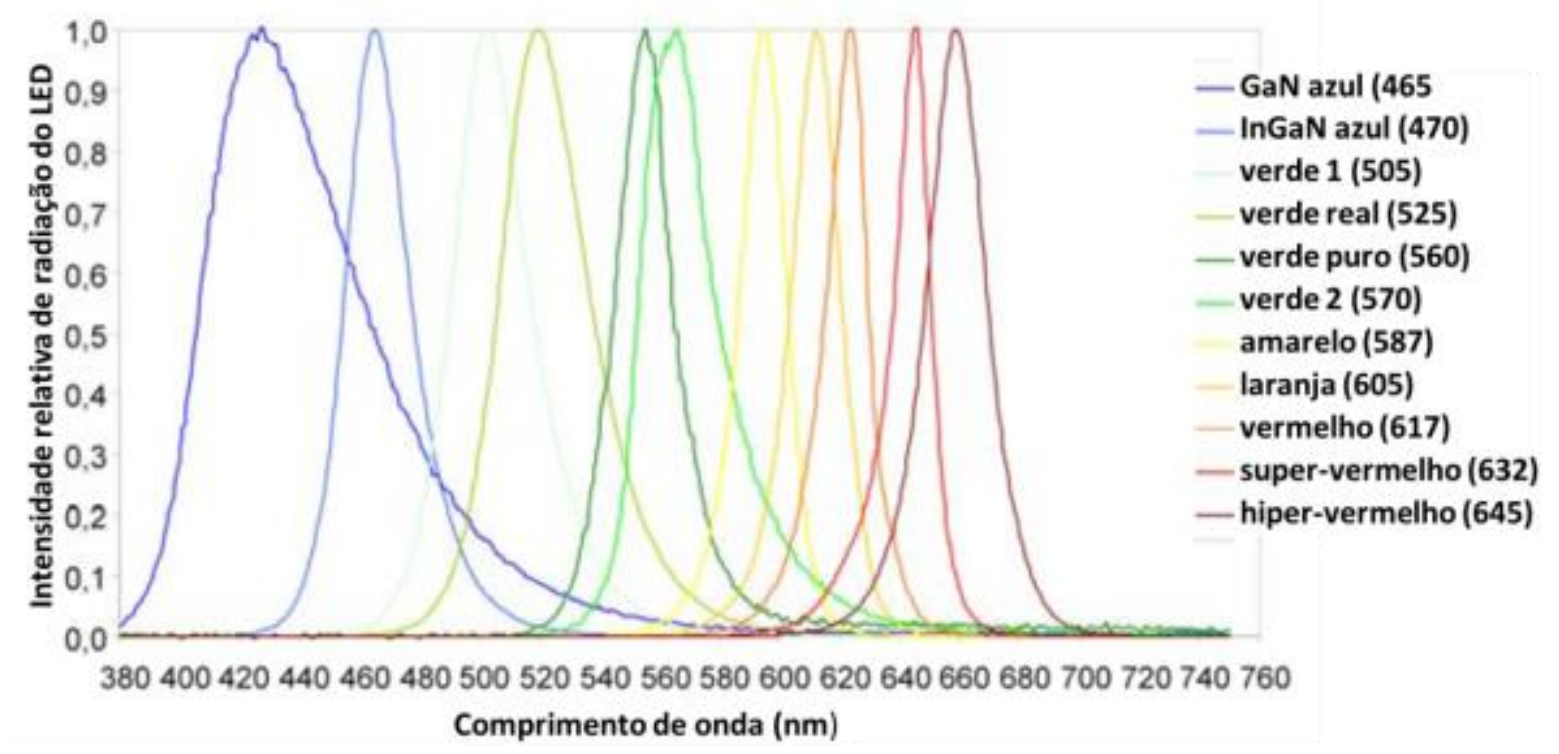

Figura A.5 Espectros irradiados por diferentes tipos de LED. 


\section{APÊNDICE B - Ensaios Dedicados}

Nesses ensaios foram avaliadas iluminações com maiores variações de tonalidade. As cores avaliadas estão mostradas nas Tabelas B.1 à Tabela B.5.

Tabela B.1 - Cores para embarque.

\begin{tabular}{|c|c|c|}
\hline Fase & Teto & Lateral \\
\hline $\begin{array}{c}\text { Embarque } \\
\text { E1 }\end{array}$ & & \\
\hline $\begin{array}{c}\text { Embarque } \\
\text { E2 }\end{array}$ & & \\
\hline $\begin{array}{c}\text { Embarque } \\
\text { E3 }\end{array}$ & & \\
\hline $\begin{array}{c}\text { Embarque } \\
\text { E4 }\end{array}$ & & \\
\hline
\end{tabular}


Tabela B.2 - Cores para cruzeiro 2.

\begin{tabular}{|c|c|c|}
\hline Fase & Teto & Lateral \\
\hline C2 1 & & \\
\hline $\begin{array}{c}\text { Cruzeiro 2 } \\
\text { C2 2 }\end{array}$ & & \\
\hline Cruzeiro 2 & & \\
C2 3 & & \\
\hline Cruzeiro 2 & & \\
C2 4 & & \\
\hline Cruzeiro 2 & & \\
C2 5 & & \\
\hline Cruzeiro 2 & & \\
C2 6 & & \\
\hline Cruzeiro 2 & & \\
C2 7 & & \\
\hline Cruzeiro 2 & & \\
C2 8 & & \\
\hline Cruzeiro 2 & & \\
\hline Cruzeiro 2 10 & & \\
\hline
\end{tabular}


Tabela B.3 - Cores para cruzeiro 1.

\begin{tabular}{|c|c|c|}
\hline Fase & Teto & Lateral \\
\hline Cruzeiro 1 & & \\
\hline Cruzeiro 1 & & \\
C1 2 & & \\
\hline Cruzeiro 1 & & \\
C1 3 & & \\
\hline Cruzeiro 1 & & \\
C1 4 & & \\
\hline Cruzeiro 1 & & \\
C1 5 & & \\
\hline Cruzeiro 1 & & \\
C1 6 & & \\
\hline Cruzeiro 1 & & \\
C1 7 & & \\
\hline Cruzeiro & & \\
C1 8 & & \\
\hline Cruzeiro 1 & & \\
\hline Cruzeiro 1 10 & & \\
\hline
\end{tabular}


Tabela B.4 - Cores para serviço de bordo.

\begin{tabular}{|c|c|c|}
\hline Fase & Teto & Lateral \\
\hline Serviço de & & \\
A1 & & \\
\hline Serviço de & & \\
Bordo & & \\
A2 & & \\
\hline Serviço de & & \\
Bordo & & \\
A3 & & \\
\hline Serviço de & & \\
Bordo & & \\
A4 & & \\
\hline Serviço de & & \\
Bordo & & \\
A5 & & \\
\hline Serviço de & & \\
Bordo & & \\
A6 & & \\
\hline Serviço de & & \\
Bordo & & \\
A7 & & \\
\hline Serviço de & & \\
Bordo & & \\
A8 & & \\
\hline Serviço de & & \\
Bordo & & \\
A9 & & \\
Serviço de & & \\
\hline A10 & & \\
\hline
\end{tabular}


Tabela B.5 - Cores para desembarque.

\begin{tabular}{|c|c|c|}
\hline Fase & Teto & Lateral \\
\hline Desembarque & & \\
\hline $\begin{array}{c}\text { Desembarque } \\
\text { D2 }\end{array}$ & & \\
\hline $\begin{array}{c}\text { Desembarque } \\
\text { D3 }\end{array}$ & & \\
\hline $\begin{array}{c}\text { Desembarque } \\
\text { D4 }\end{array}$ & & \\
\hline
\end{tabular}

Para avaliar a adequação das cores e verificar distorções percebidas pela iluminação da cabine, fez-se uma avaliação das cores mencionadas nas Tabelas B.1 a B.5 no dia 22/03/2012, com um grupo de 18 avaliadores. No início dos ensaios os avaliadores receberam instruções de como seriam os ensaios e receberam um questionário para apontar sua avaliação das diferentes condições de iluminação da cabine. No questionário de avaliação os avaliadores informaram a sua data de nascimento, o gênero e a cor dos olhos. Solicitou-se aos avaliadores que, ao preencher 0 questionário, não conversassem e nem comentassem as questões e as respostas com seus vizinhos. No questionário deveriam responder para cada fase do voo e condição de iluminação as seguintes perguntas:

\section{Pergunta 1 - Alteração no ambiente}

Observe, em cada mudança de iluminação, se você percebe alguma distorção:

- No letreiro indicativo da poltrona

- Na leitura do safety card e da revista

- Nos objetos ao seu redor

- Nos alimentos

- Nas pessoas 


\section{Pergunta 2 - Apropriação}

Pensando em cada fase do voo analisada (embarque, cruzeiro, serviço de bordo, cruzeiro, e desembarque), avalie o quanto essa opção de iluminação é adequada?

Para o Embarque e Desembarque foram dadas as seguintes instruções:

"Antes de entrar na cabine você deverá sortear o número da poltrona que você irá se sentar.

Localize sua poltrona, sente-se e responda o questionário para a primeira opção de cor para o embarque.

Em seguida você deverá responder o questionário após cada condição de iluminação do Cruzeiro 1, Alimentação e Cruzeiro 2

Ao sinal do pesquisador, saia da cabine, devolva seu número do assento, e responda o questionário de desembarque. Antes de ingressar novamente na cabine, sorteie um novo número de assento."

O ensaio foi dividido em duas etapas, com duração aproximada de 2 horas para cada etapa, uma de manhã e uma à tarde, a fim de reduzir o cansaço na avaliação, o que poderia prejudicar os resultados.

Para avaliação das cores os avaliadores fizeram o seguinte roteiro de avaliação:

Na parte da manhã 1 Entrada, 3 Cruzeiro 1, 3 Serviço de Bordo, 3 Cruzeiro 2 e 1 Desembarque. Depois 1 Entrada, 2 Cruzeiro 1, 2 Serviço de Bordo, 2 Cruzeiro 2 e 1 Desembarque. Na parte da tarde o roteiro se repetiu. Sempre, antes do Embarque, sorteavam-se os assentos, fazendo com que os passageiros mudassem de posição para criar uma maior diversidade de situações. Na mudança da característica da iluminação, os passageiros fechavam os olhos, evitando-se desse modo impactos de percepção de mudança de cores. Aplicou-se um questionário conforme mostrado na Figura B.1. 
Estudo para definição de cromas - 22/03/2012

Dados de Identificação

1. Data de Nascimento:

2. Gênero: ( ) F ( ) M

3. Cor dos olhos:

\section{Embarque - Opção 1}

4.1 Em que poltrona você está sentado?

Nesta opção de iluminação, você percebe alguma alteração no ambiente?

4.2 ( ) no letreiro indicativo da poltrona e avisos impressos

4.3 ( ) nos objetos ao seu redor (relógio, poltrona, alimentos)

4.4 ( ) nas pessoas

4.5 ( ) não percebe alteração

4.6 Como você considera a iluminação do ambiente?

inadequada

muito adequada

\begin{tabular}{|l|l|l|l|l|l|l|l|l|l|l|}
\hline 0 & 1 & 2 & 3 & 4 & 5 & 6 & 7 & 8 & 9 & 10 \\
\hline
\end{tabular}

Figura B.1 Questionário para avaliação da adequalção das cores de iluminação da cabine

\section{Resultados do ensaio dedicado}

Seguem os resultados obtidos e considerações:

As médias dos valores obtidos para as diversas fases e diversas opções, estão apresentadas nas Figuras B.2 a B.6, onde são mostradas as médias obtidas pelos avaliadores localizados no corredor, as médias obtidas pelos avaliadores localizados na janela e a média geral, para da opção de condição de iluminação e para cada fase. Adota-se avaliações da iluminação do ambiente com valores acima de 6,0 pontos como sendo consideradas positivas, ou seja, são cores adequadas para aquela fase do voo.

EMBARQUE (Figura B.2): todas as médias foram superiores a 6,0 pontos, ou seja, todas as cores são adequadas ao embarque. Não houve variação significativa dos 
resultados entre pessoas sentadas próximas ao corredor e sentadas próximas à janela. O desvio padrão médio para essa fase foi 1,8 pontos. Não perceberam alteração no ambiente.

CRUZEIRO 1 (Figura B.3): as opções de cores 6 Cruzeiro 1-Opção 2, 17 Cruzeiro 1Opção 5, 24 Cruzeiro 1-Opção 6, 25 Cruzeiro 1-Opção 7, 35 Cruzeiro 1-Opção 9, 36 Cruzeiro 1-Opção 10 foram consideradas adequadas para a fase de Cruzeiro 1. As médias das avaliações das pessoas sentadas próximas da janela foram superiores a das médias das avaliações das pessoas sentadas próximas ao corredor, exceto para as opções 5 Cruzeiro 1-Opção 1, 6 Cruzeiro 1-Opção 2, 7 Cruzeiro 1-Opção3, 16 Cruzeiro 1-Opção 4 E 25 Cruzeiro 1-Opção 7. O desvio padrão médio para essa fase foi 2,4 pontos, evidenciando grande variação de percepção da adequação da iluminação da cabine entre os avaliadores. Para médias de pontuações acima de 6,0 pontos os avaliadores não perceberam alterações no ambiente, para pontuações abaixo de 6,0 pontos os avaliadores perceberam alterações no ambiente.

SERVIÇO DE BORDO (Figura B.4): as opções de cores 8 Alimentação-Opção 1, 10 Alimentação-Opção 3, 19 Alimentação-Opção 5, 27 Alimentação-Opção 6, 28 Alimentação-Opção 7, 29 Alimentação-Opção 8, 37 Alimentação-Opção 9 apresentaram médias superiores a 6,0 pontos, sendo dessa maneira consideradas cores adequadas à alimentação. De maneira geral, as médias das avaliações das pessoas sentadas próximas ao corredor foram superiores às das pessoas sentadas próximas à janela. O desvio padrão médio para essa fase foi 2,1 pontos. Para médias de pontuações acima de 6,0 pontos os avaliadores não perceberam alterações no ambiente com exceção da opção 29 ALIMENTAÇÃO-OPÇÂO 8, porém para médias de pontuações abaixo de 6,0 pontos percebeu-se alterações no ambiente.

CRUZEIRO 2 (Figura B.5): as opções de cores 20 Cruzeiro 2-Opção 4, 21 Cruzeiro 2Opção 5, 30 Cruzeiro 2-Opção 6, 32 Cruzeiro 2-Opção 8, 39 Cruzeiro 2-Opção 9, 40 Cruzeiro 2-Opção 10 foram consideradas adequadas para o cruzeiro 2. De modo geral as médias das avaliações das pessoas sentadas próximas à janela foram superiores as médias das pessoas próximas ao corredor. O desvio padrão médio para essa fase foi 2,4 pontos, evidenciando grande variação de percepção da adequação da iluminação da cabine entre os avaliadores. Com relação à percepção de alteração do ambiente, não houve correlação com a média dos pontos, não se percebendo 
alterações do ambiente para 11 Cruzeiro 2-Opção 1, 31 Cruzeiro 2-Opção 7, 13 Cruzeiro 2-Opção 3, 32 Cruzeiro 2-Opção 8, 20 Cruzeiro 2-Opção 4 E 40 Cruzeiro 2Opção 10.

DESEMBARQUE (Figura B.6): as opções 14 DESEMBARQUE-OPÇÃO 1, 22 DESEMBARQUE-OPÇÃO 2, 41 DESEMBARQUE-OPÇÃO 4 foram consideradas adequadas ao desembarque. Não houve diferença significativa entre as médias das avaliações dos avaliadores sentados próximas à janela e próximas ao corredor. $\mathrm{O}$ desvio padrão médio para essa fase foi 1,8 pontos. Não houve percepção de alteração do ambiente.

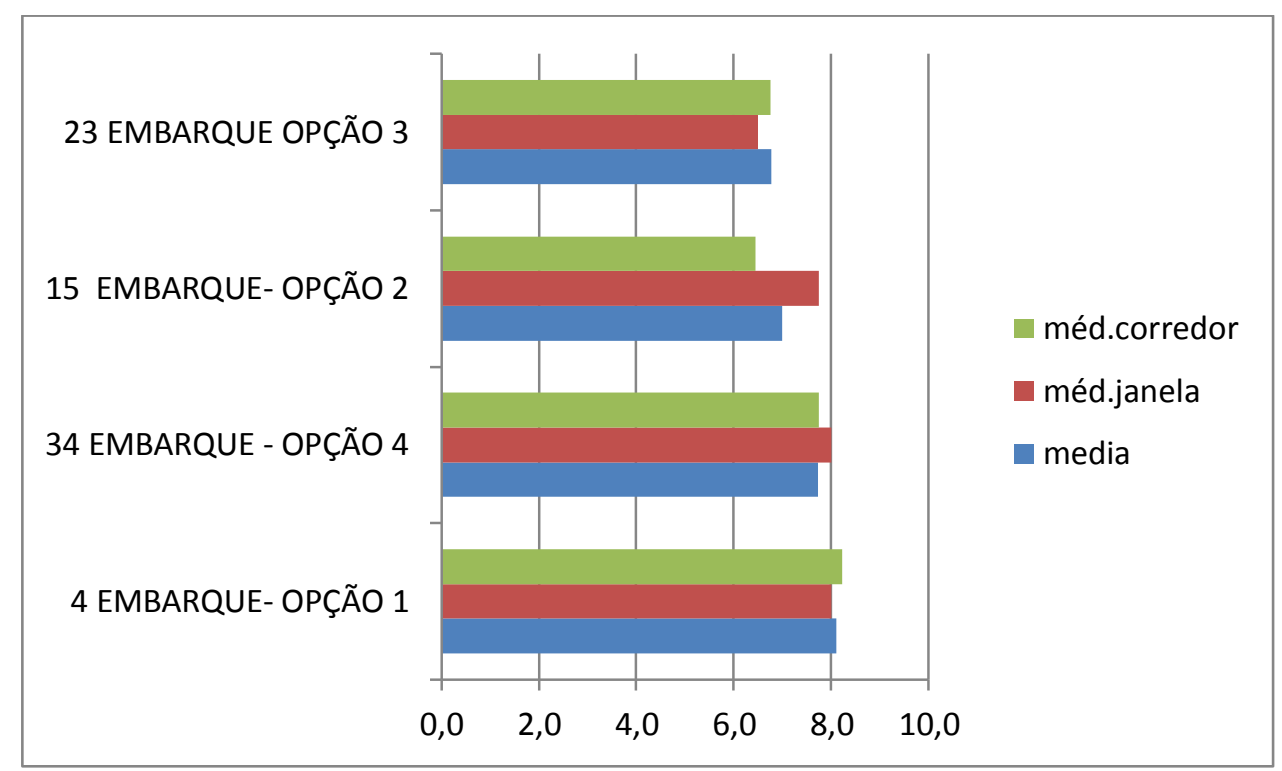

Figura B.2 Médias ds pontuações obtidas para a fase de Embarque 


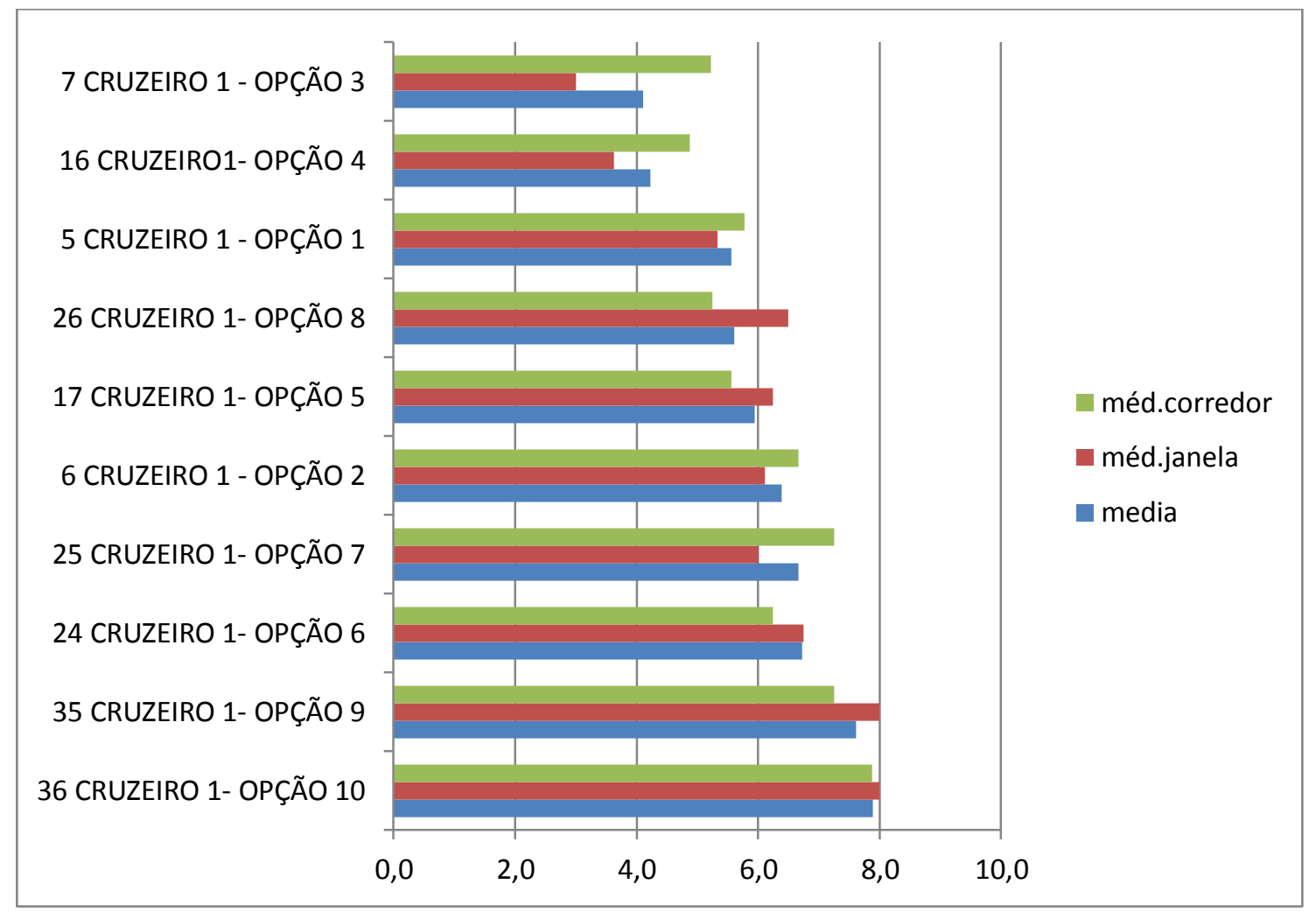

Figura B.3 Médias das pontuações obtidas para a fase de cruzeiro 1

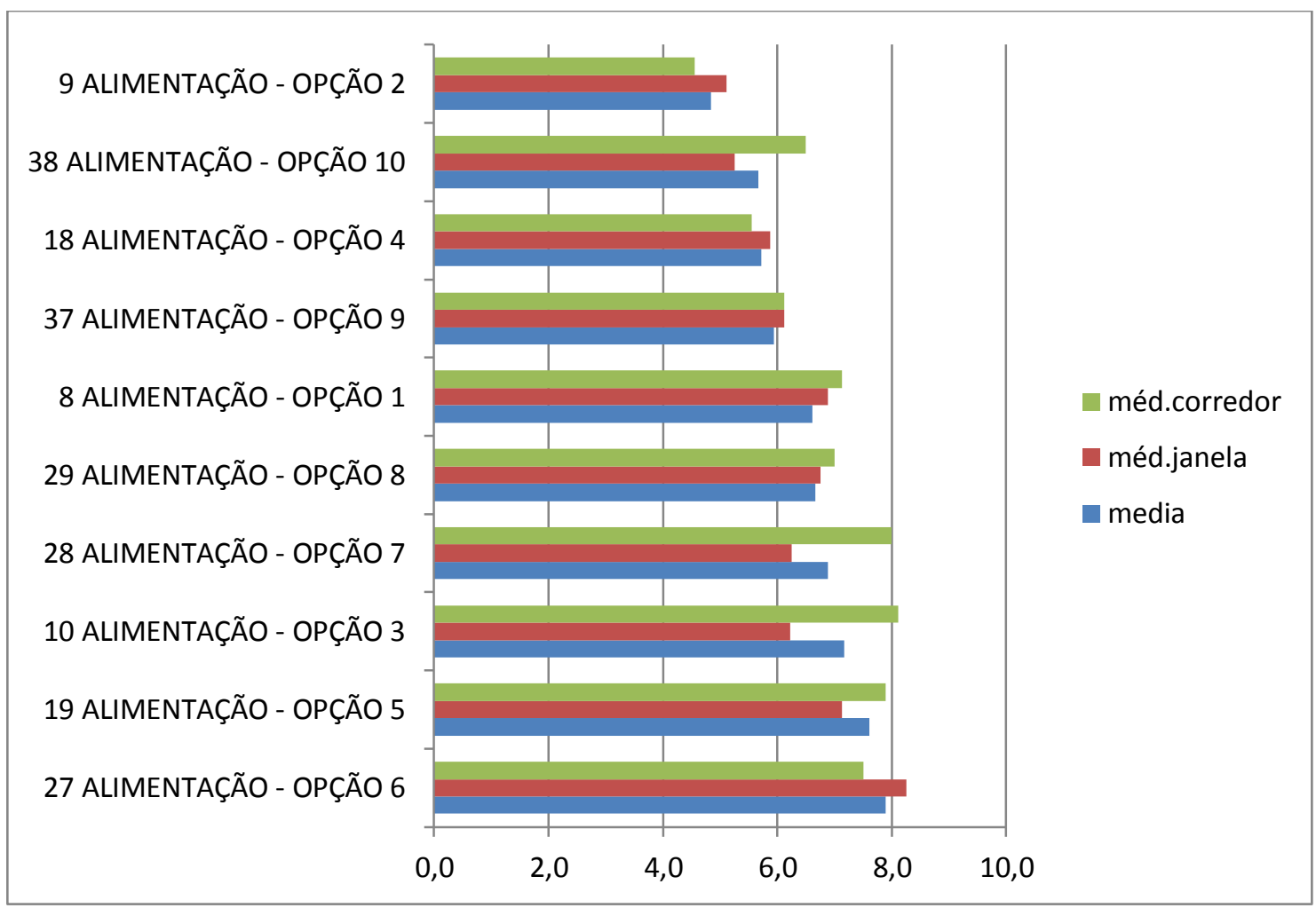

Figura B.4 Médias das pontuações obtidas para a fase de Serviço de Bordo 


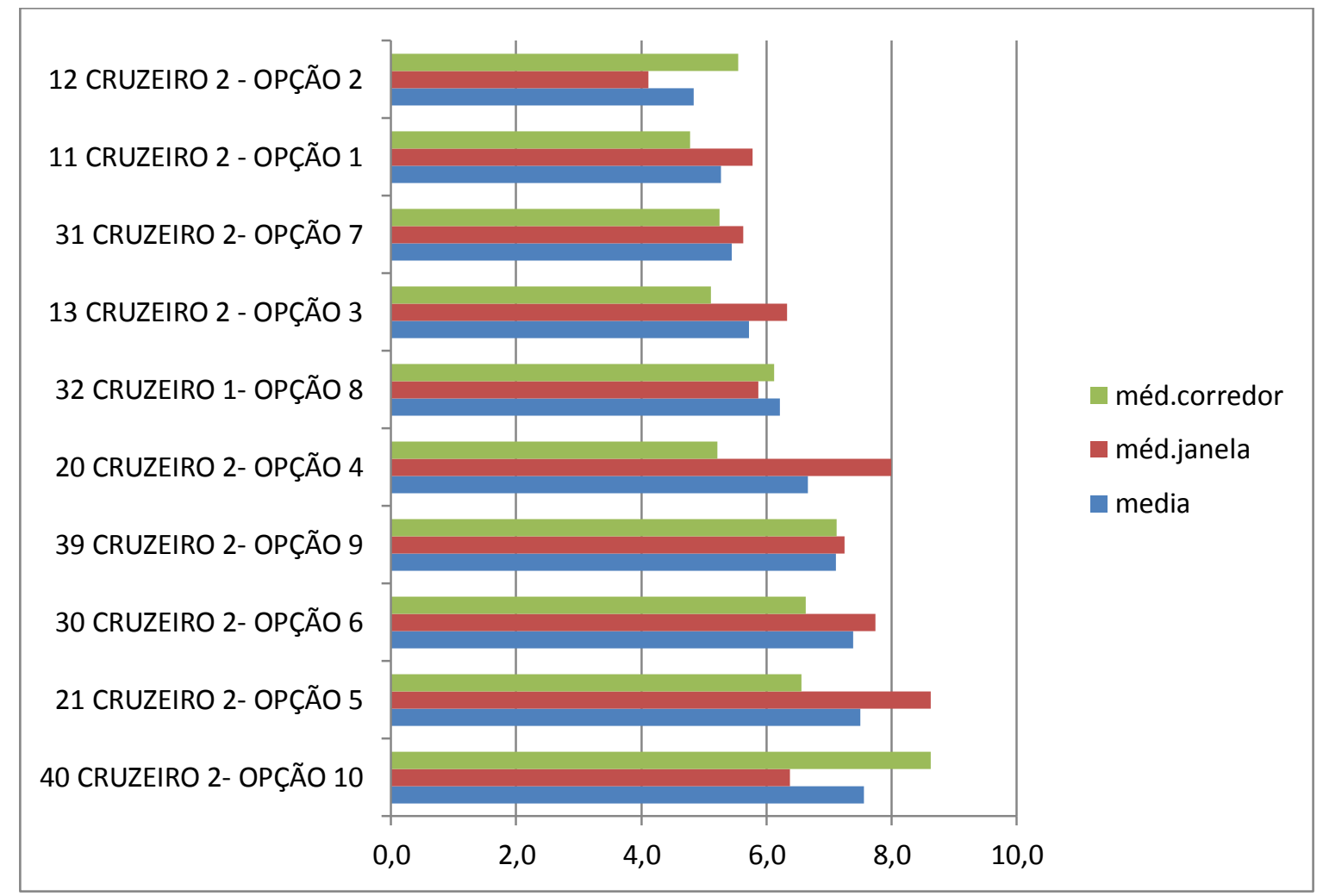

Figura B.5 Médias das pontuações obtidas para a fase de cruzeiro 2

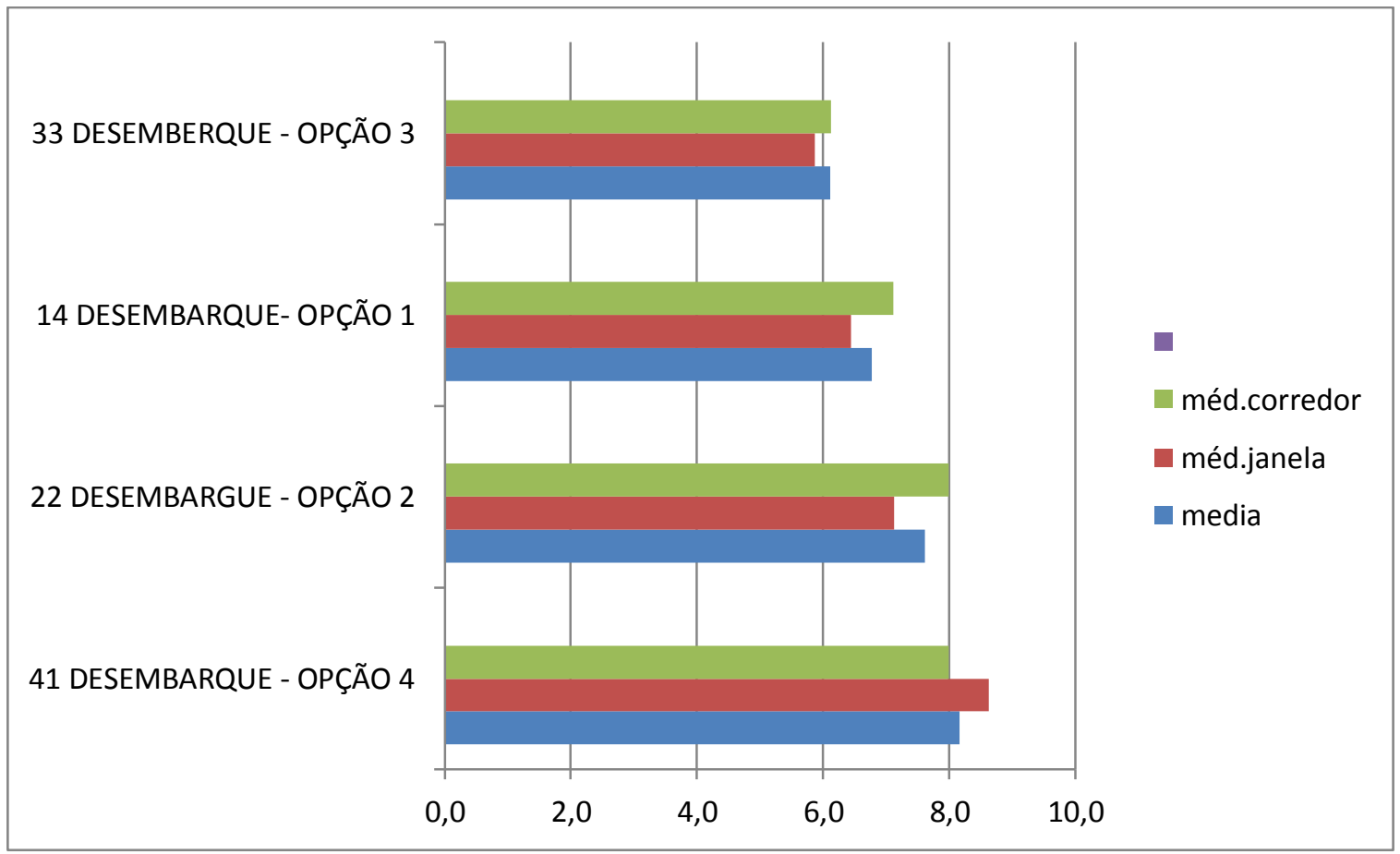

Figura B.6 Médias das pontuações obtidas para a fase de Desembarque 
Pela análise dos dados coletados, verifica-se a influência de características físicas na percepção de determinada iluminação, bem como, a localização espacial do indivíduo para classificá-la como adequada ao contexto e às necessidades individuais e percebê-la como confortável ou desconfortável. 


\section{APÊNDICE C - O olho humano}

\section{Descrição do olho e da formação de imagem}

O olho humano é um elemento fundamental para o sistema visual, ele é ponto de entrada das radiações eletromagnéticas para o sistema cognitivo. O sentido da visão é a interação da luz com os receptores especializados da retina. O olho otimiza a formação de imagens focalizadas do mundo exterior. Lent (2010), assim como outros autores, compara o olho a uma câmera automática, que posiciona a lente na direção do objeto desejado e regula a abertura da câmera ou a sensibilidade do filme em função da iluminação disponível (LENT, 2010, p. 297). O olho é o receptor, que capta a energia e o cérebro, o processador das informações recebidas, em que o cérebro compara, analisa, sintetiza, usa as emoções e intuições para decodificar os dados recebidos e projetar um futuro no presente para viabilizar as tomadas de decisões (FLOR; CARVALHO, 2012 p. 334). O processo de transformação dos estímulos recebidos em informações dotadas de sentido permite que o homem perceba as nuanças das cores e outras características do mundo externo, como intensidade da luz ambiente, localização espacial dos objetos de interesse, brilho, forma, posição, movimento, sombra ou reflexo.

A córnea e o cristalino, além de outros componentes, são responsáveis por formar as imagens na retina, isto é, convergir a luz do ambiente para o interior do olho. Esses componentes são mostrados na Figura C.1. 


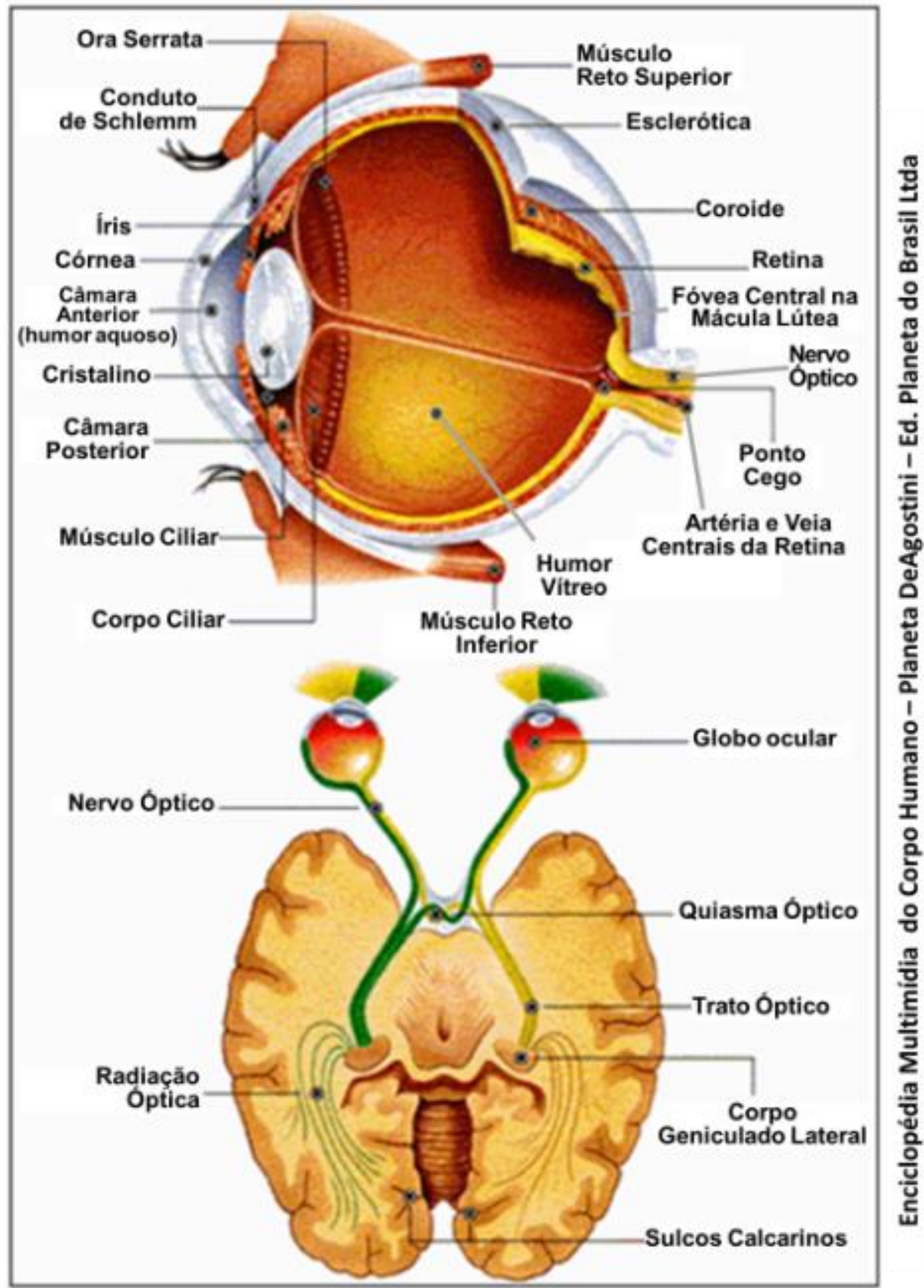

Figura C.1- Estrutura do olho humano

Para se detectar uma imagem pelo sistema visual, ela deve ser focada na retina. Para isso o sistema ocular possui recursos, tais como: músculos que movimentam o globo ocular e fazem com que os dois olhos focalizem o mesmo ponto de atenção; meios aquosos com índices de refração distintos que alteram a direção dos raios luminosos no interior do olho e filtram determinados comprimentos de onda; e principalmente o cristalino que altera sua própria forma de modo a convergir os raios luminosos na retina. A Figura C.2 apresenta as acomodações do cristalino para diferentes 
distâncias do objeto ao olho. Quando o objeto está distante, o cristalino tem uma forma menos convexa do que quando o objeto está próximo.

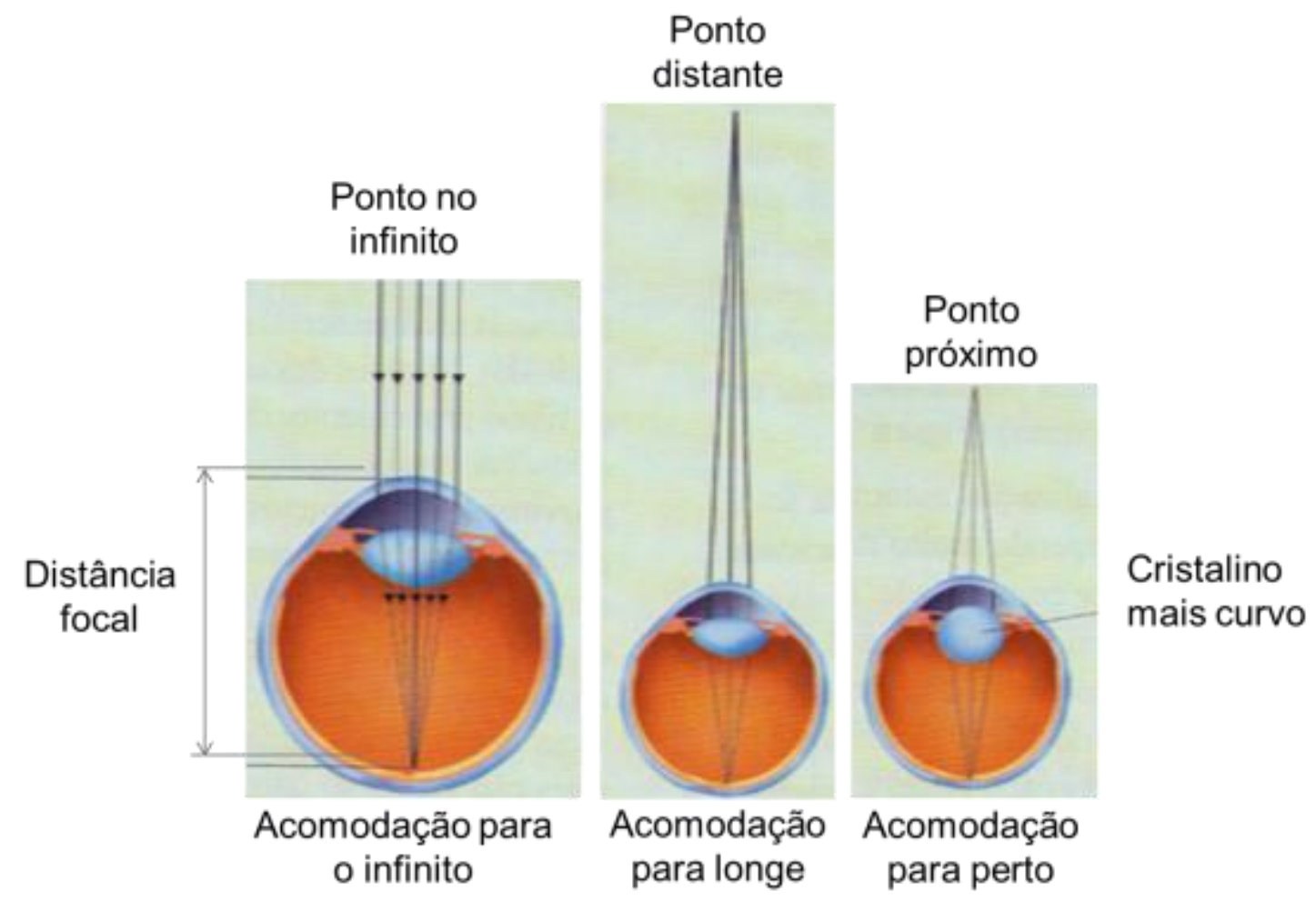

Figura C.2. Acomodação do cristalino em função da distância do objeto (LENT, 2010, p. 305).

A formação da imagem da cena observada e captada pelos dois olhos é exemplificada na Figura C.3. Observa-se que a formação da imagem em cada olho é diferente, anamorfismo, devido à não simetria dos olhos, geometria esférica do globo ocular e pela obstrução visual causada pelo nariz, o que resulta em um campo de visão diferente para cada olho, porém o cérebro a decodifica e a interpreta como única. 


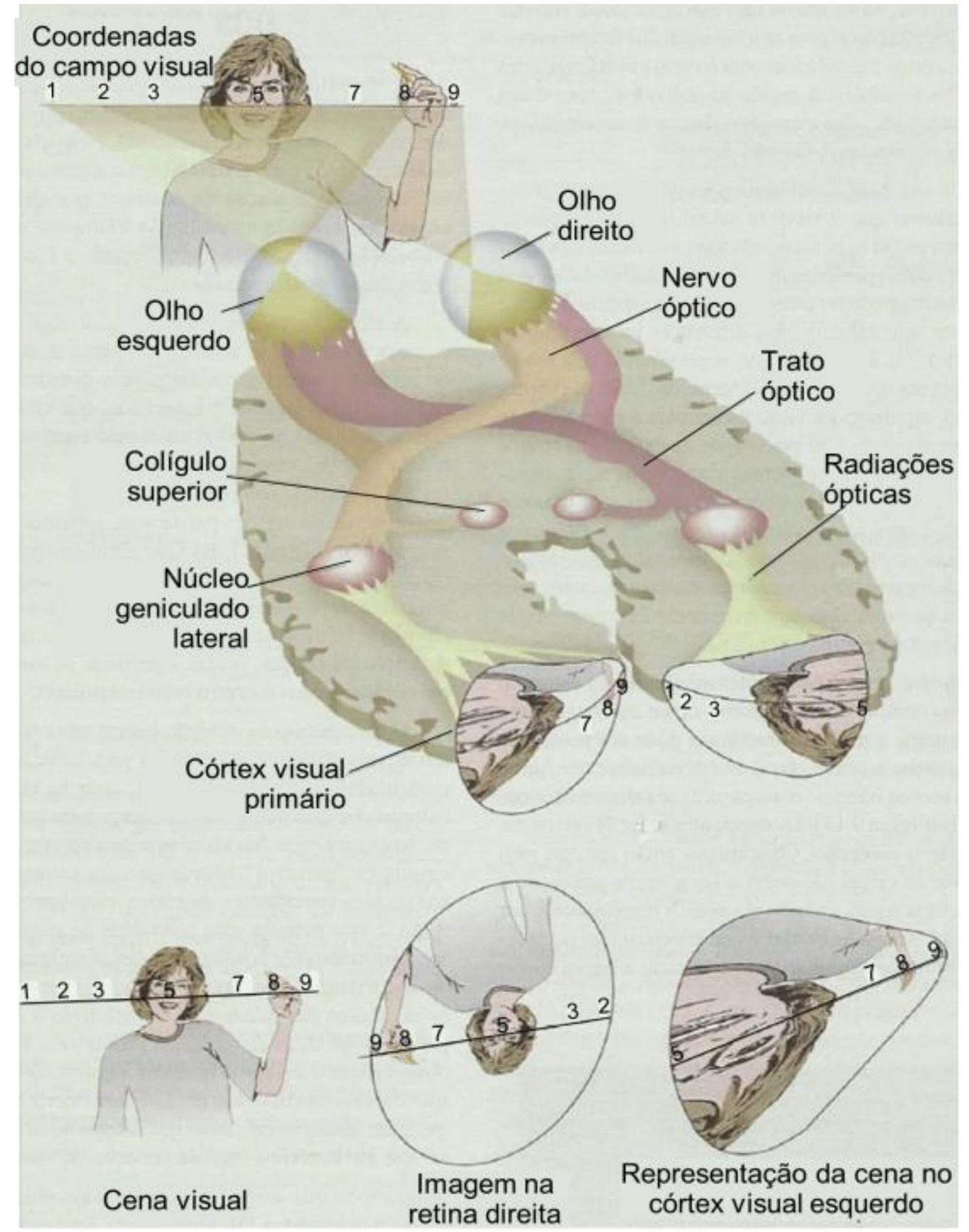

Figura C.3. Anamorfose da imagem visual na retina (LENT, 2010, p. 324).

A intensidade luminosa além de seu valor objetivo, que é obtido por meio de equipamentos eletrônicos, também tem valor subjetivo que é o resultado das adaptações do sistema visual em função dos estímulos recebidos. Esses fatores são, além da energia luminosa, a capacidade de adaptação da retina, o nível de ruído interno criado pelo próprio sistema visual, a cor do que se observa e as condições de 
contorno a cena observada (LENT, 2010, p. 324). Tais adaptações fazem com que a luz de uma vela acesa à noite aparente ser mais intensa do que de dia, apesar de sua energia irradiada ser a mesma.

O sistema visual consiste em um trabalho conjunto do olho e do cérebro para interpretar o ambiente visual. Uma fonte de radiação eletromagnética emite vários comprimentos de onda que incidem em um objeto, direta ou indiretamente. Esse objeto absorve determinados comprimentos de onda e emite outros. A radiação emitida pelo objeto atinge o olho e é filtrada pelo humor vítreo, humor aquoso, cristalino e, pelos elementos óticos do olho, convergem para a retina. A retina possui fotorreceptores que absorvem os fótons e converte a energia recebida em impulsos elétricos. Pelo nervo ótico, os impulsos são transmitidos para o corpo geniculado lateral e enviados para o córtex visual, onde a imagem é processada, e finalmente reconhecida.

É, portanto, por meio de filtros, de transformações dos sinais recebidos e do sistema cognitivo, que as radiações eletromagnéticas são transformadas de maneira que o homem visualize e perceba os objetos a sua volta.

Como a visão depende da luz, é a iluminação que propicia condições para que o homem possa exercer suas atividades de modo eficiente, seguro e confortável. Para antecipar as reações humanas em função da iluminação, é necessário entender as características físicas, fisiológicas e perceptivas do nosso sistema visual.

Aponta-se ainda o fato de que o sistema visual sofre deterioração com o passar do tempo. Esse fenômeno, ao lado de outros, influencia a caracterização de conforto/desconforto, de um ambiente, para a ação simultânea de diferentes faixas etárias. Na Figura C.4 observa-se o estudo realizado por Bommel e Beld (2004) a respeito da alteração da capacidade visual entre jovens e idosos. Os primeiros apresentaram desempenho superior aos idosos, com o mesmo nível de iluminamento. 

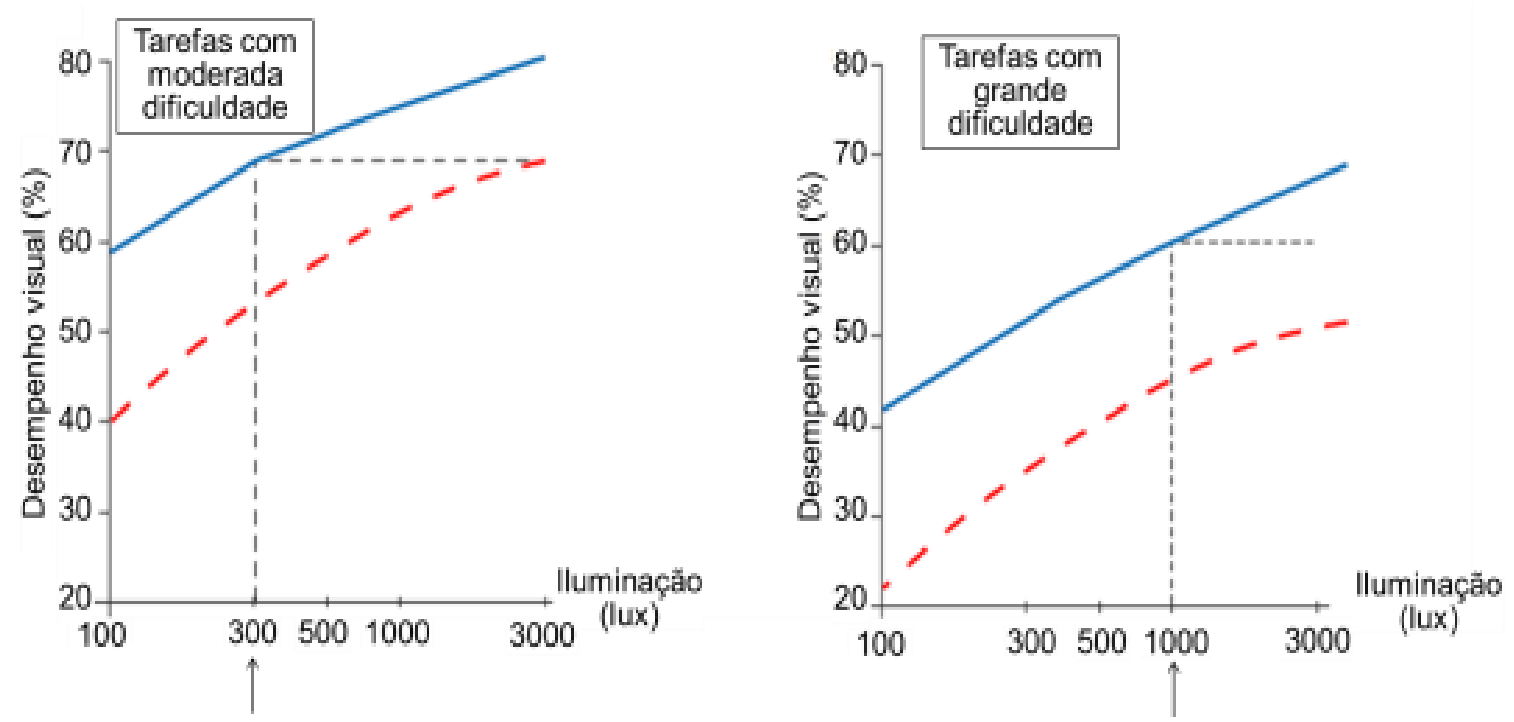

Figura C.4 - Relação entre desempenho visual (em \%) e nível de iluminação (em lux). Linha azul contínua: pessoas jovens; linha vermelha tracejada: pessoas idosas (BOMMEL, 2004, p. 10).

A análise da Figura C.4 permite concluir que um ambiente iluminado, por exemplo, com 300 lux, obtém-se $70 \%$ de desempenho visual para jovens, em realizações de tarefas de nível médio, e que esse mesmo rendimento é obtido somente com 1000 lux para pessoas idosas. Dessa maneira, é possível adequar a iluminação para compensar a perda visual de pessoas idosas. Porém, para tarefas de alto grau de dificuldade, que requerem iluminação de 1000 lux, para jovens, não é possível fazer a compensação para pessoas idosas.

A transmitância do olho varia com o comprimento de onda e com a idade. A córnea absorve a maior parte dos comprimentos de onda menores do que $300 \mathrm{~nm}$. No entanto, o cristalino torna-se amarelado com o tempo. Esse amarelamento atenua a radiação total incidente na retina, especialmente em comprimentos de onda visíveis curtas e UV (IESNA, 2000). Na Figura C.5 são apresentadas diversas curvas de transmissão da luz em função do comprimento de onda e em relação ao componente do olho. As linhas sólidas representam o resultado da transmitância total da luz, luz direta mais luz difusa, através do olho e em função do comprimento de onda. As curvas tracejadas representam a transmitância direta da luz, desconsiderando o efeito da difusão. A diferença entre as duas curvas, sólida e tracejada, representa a perda de transmissão por difusão. Quando houver mais de uma curva tracejada, a inferior representa o efeito do envelhecimento/amarelamento do componente do olho. 
$\mathrm{Na}$ região visível do espectro, as ópticas do olho transmitem mais luz para comprimentos de onda longos (vermelho) do que para comprimentos de onda curta (azul), uma tendência que é aumentada na fóvea pela absorção de comprimentos de onda curta pela mácula lútea, um filtro que fica logo acima da fóvea. Em média 70 a $85 \%$ do espectro visível atinge a retina de olhos jovens (IESNA, 2000).

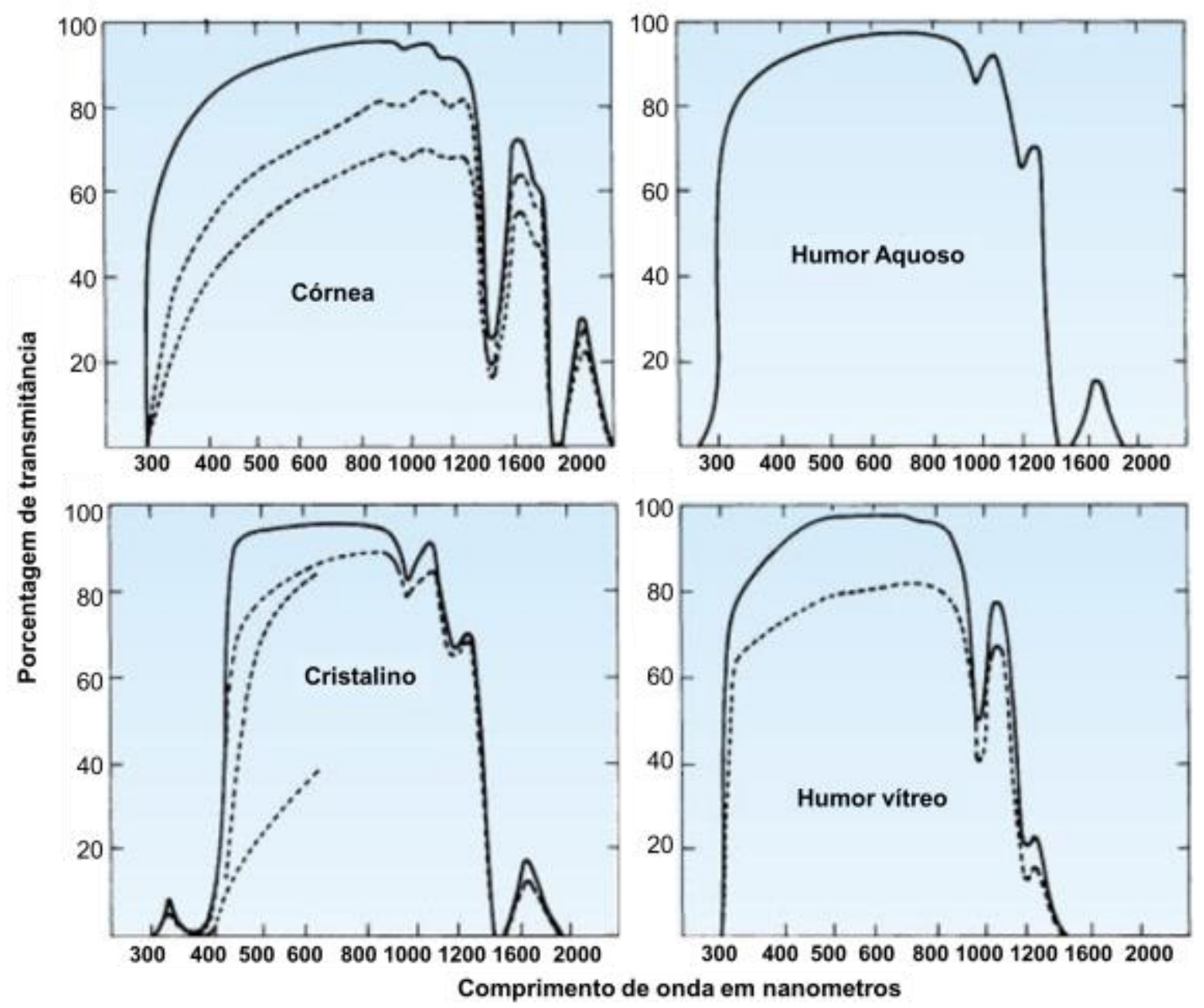

Figura C.5. Propriedades de transmissão espectral dos componentes do olho humano (IESNA, 2000 pág. 92).

Com o passar do tempo a redução geral na transmitância, com todos os comprimentos de onda combinados, apresenta uma acentuada redução (maior do que quatro vezes) em comprimentos de onda curtas, devido, principalmente, ao amarelamento do cristalino (IESNA, 2000). A Figura C.6 apresenta um gráfico da variação da densidade óptica (densidade óptica: $D=\log (1 / t)$, onde $t=$ transmitância total) em função da idade. Observa-se que quanto mais idosa for a pessoa, maior será a densidade óptica (menor transmitância) e, consequentemente, maior dificuldade de visual. 


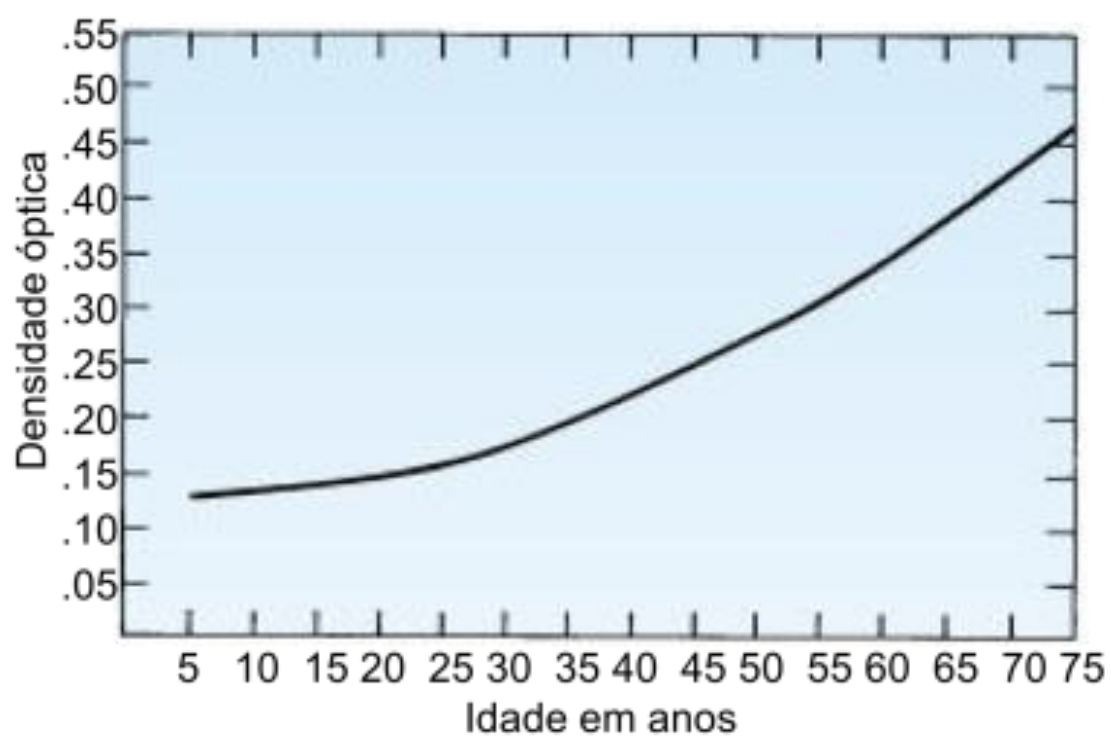

Figura C.6 A densidade óptica do cristalino humano a 490nm em função da (densidade óptica $D=\log (1 / t)$, onde $t=$ transmitância total) $($ IESNA, 2000).

\section{Componentes motores}

A área de observação, região onde o sistema ocular se adapta para focalizar uma cena ou objeto, muda constantemente. A mudança da região de concentração pode ser feita ou pela movimentação da cabeça ou pela movimentação do olho. Em função da massa da cabeça ser bem maior do que a massa do olho é mais fácil movimentar os olhos do que a cabeça, principalmente nos deslocamentos onde se requeira rapidez na mudança de região a ser observada. Três pares de músculos são responsáveis para executar os movimentos oculares, os quais são ilustrados na Figura C.7. Esses músculos posicionam a linha de visão de ambos os olhos de maneira que eles são focados no mesmo objeto de observação. São 6 músculos 4 retos e 2 oblíquos. Os músculos reto superior e inferior são responsáveis pela elevação e depressão do olho (movimento para cima e para baixo); os músculos reto médio e lateral permitem a movimentação lateral do olho e os músculos oblíquos permitem a rotação do globo ocular. As funções de elevação e depressão dos músculos variam de acordo com a posição do olho. 


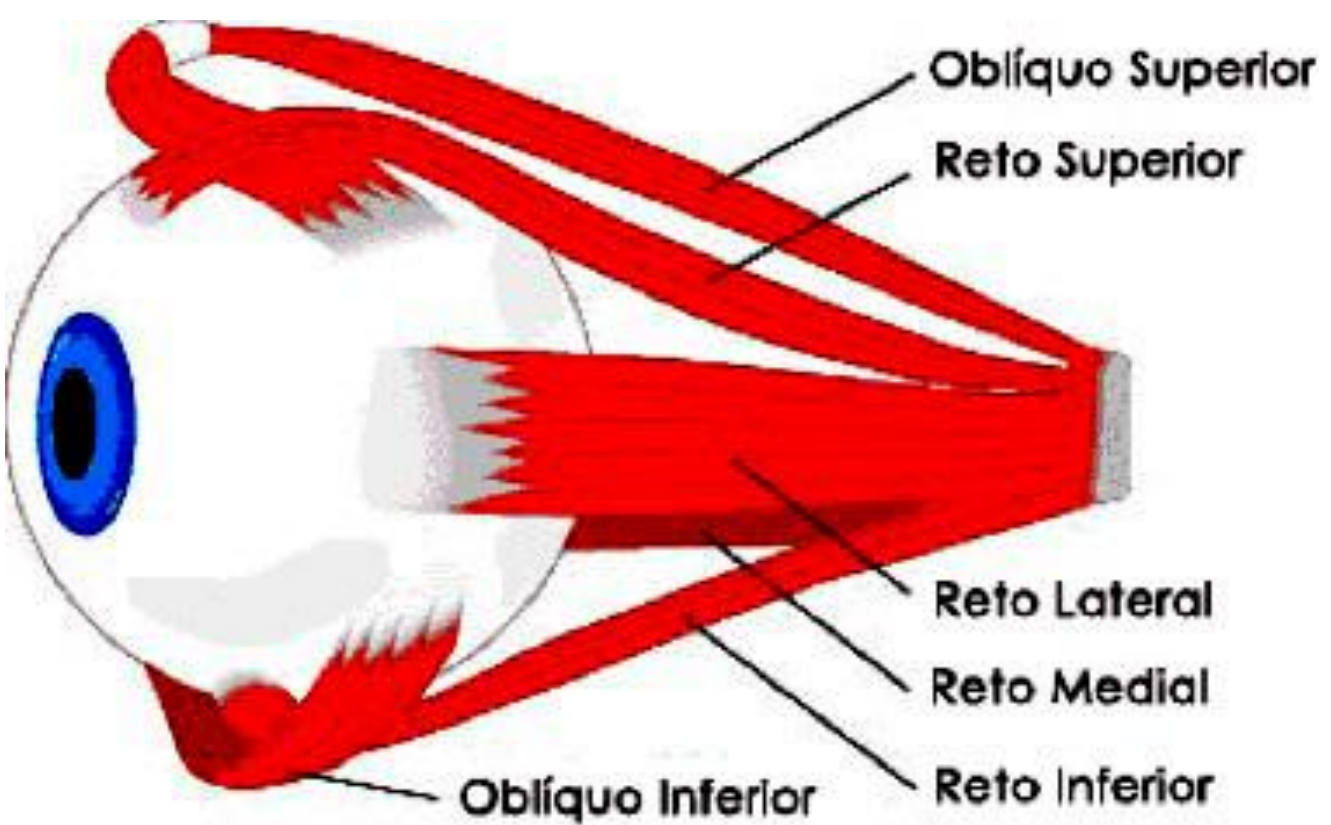

Figura C.7 - Músculos oculares (Prof. Dr. Luciano P. Bellini "ceoportoalegre.com.br")

Dentre os mais importantes movimentos do olho, segundo Tunnacliffe (1993) destacam-se:

- Movimentos sacádicos (sacadas) - surgem quando se procura algum objeto. São movimentos muito rápidos, com duração de 150-200ms para planejamento e execução da visão, ou seja, tempo necessário para focar um objeto. O início da movimentação dos olhos tem um retardo de $30 \mathrm{~ms}$. A velocidade de giro do olho é de 900 graus/s.

- Movimentos de perseguição (Figura C.8a) - trata-se de movimentos lentos de acompanhamento da movimentação de um objeto. A velocidade de giro do olho varia de 10 a 100 graus/s. O ângulo entre os olhos não muda e a imagem de fundo está desfocada.

- Movimentos de vergência (Figura C.8b) - ocorrem quando o homem aproxima ou se afasta o objeto do olho. São movimentos lentos, com velocidade de rotação do olho de 10 graus/s. O ângulo entre os olhos muda. 


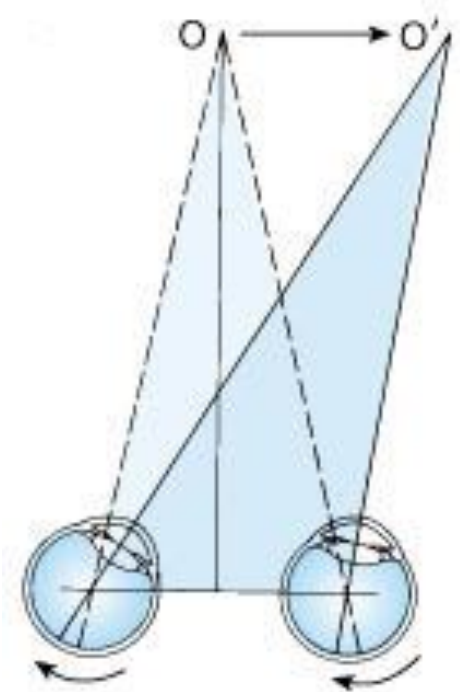

Figura C.8a - perseguição O objeto se desloca de O para O' IESNA (2000).

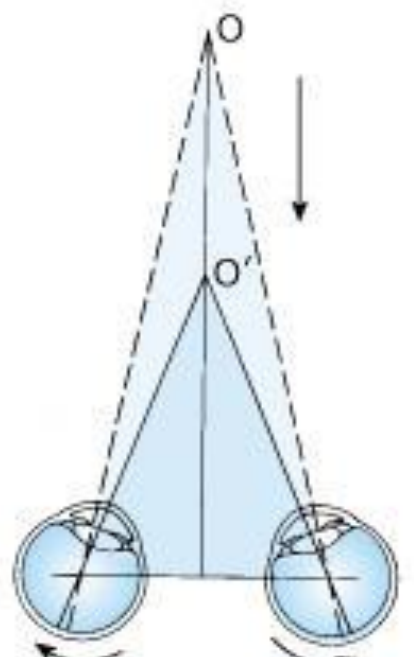

Figura C.8b - vergência O objeto se desloca de O para O' IESNA (2000).

O campo de visão pode ser dividido em três áreas de acuidade visual: campo de visão total (ângulo máximo de visibilidade), campo de visão preferencial (ângulo de visão que circunda a tarefa em execução) e campo de visão ótimo (ângulo de focalização da tarefa em execução). Os valores dos ângulos de visibilidade desses campos são apontados na Figura C.9 (GANSLANDT; HOFMANN, 1992). O quadrante superior esquerdo apresenta o campo de visão horizontal; o quadrante superior direito, o campo de visão vertical de uma pessoa em pé, o quadrante de visão inferior esquerdo, mostra o campo de visão de leitura na posição sentada e, por último, o quadrante inferior direito mostra o campo de visão de uma pessoa sentada com a visão horizontal. Em função das limitações do campo visual, a posição dos passageiros de avião sentados próximos às janelas ou próximos ao corredor pode ser um fator importante na determinação do desconforto de iluminação, uma vez que a visão é limitada em determinados ângulos.

Outra característica a ser considerada é o campo de visão do olho humano não ser simétrico, há diferenças entre o esquerdo e o direito, devido a obstruções anatômicas - nariz, pálpebras e ossos da face. O pesquisador Inkarojrit (2005) mostra a assimetria de visualização na Figura C.10. Observa-se que na linha horizontal e central, o campo de visão do olho direito situa-se entre $60^{\circ}$ à esquerda e $90^{\circ}$ à direita, ao passo que o olho esquerdo o campo de visão é $90^{\circ}$ à esquerda e $60^{\circ}$ à direita. 

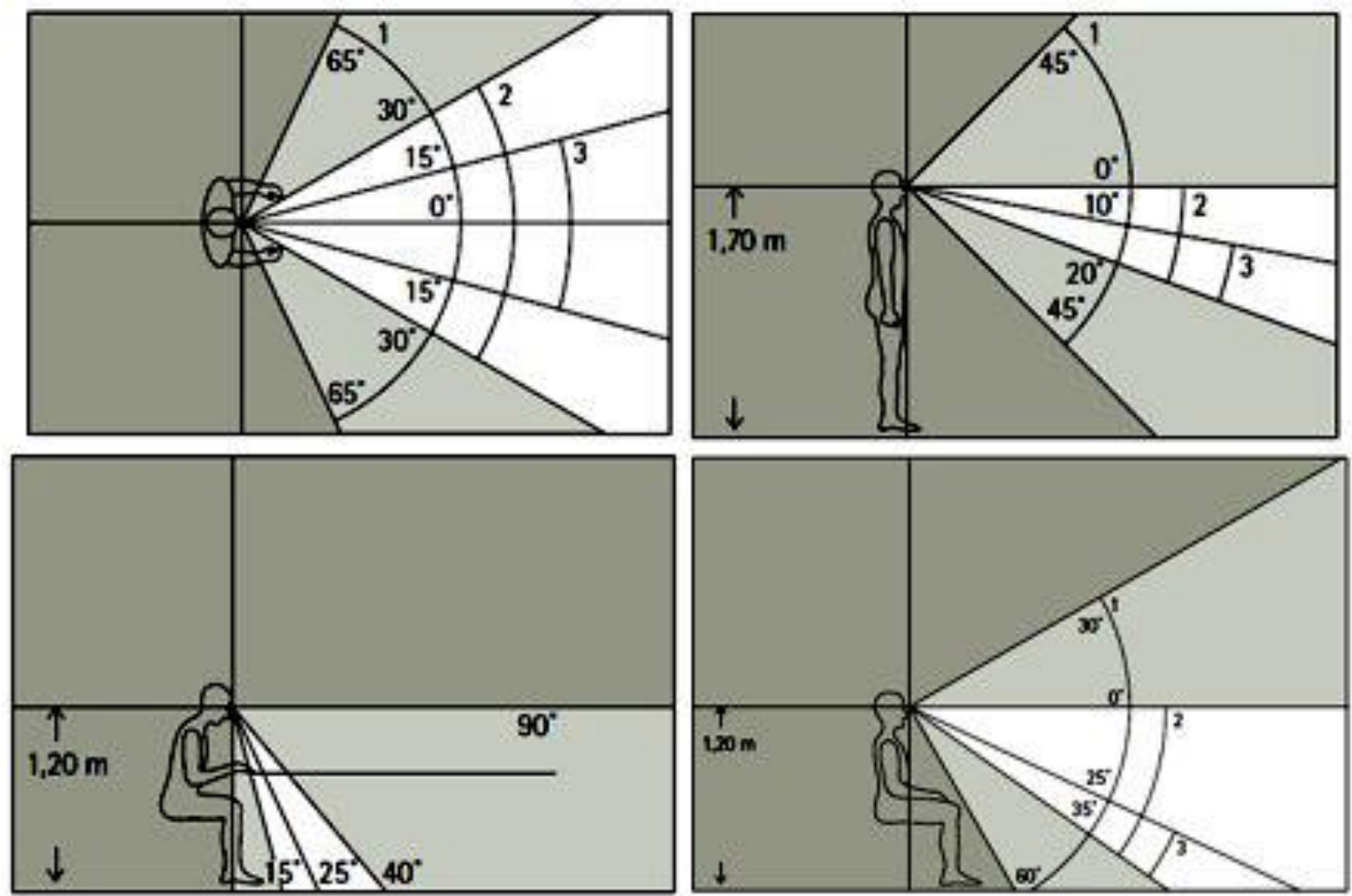

Figura C.9 - Campo de visão (1), campo de visão preferencial (2) e campo de visão ótimo (3) (GANSLANDT; HOFMANN, 1992, p. 38).

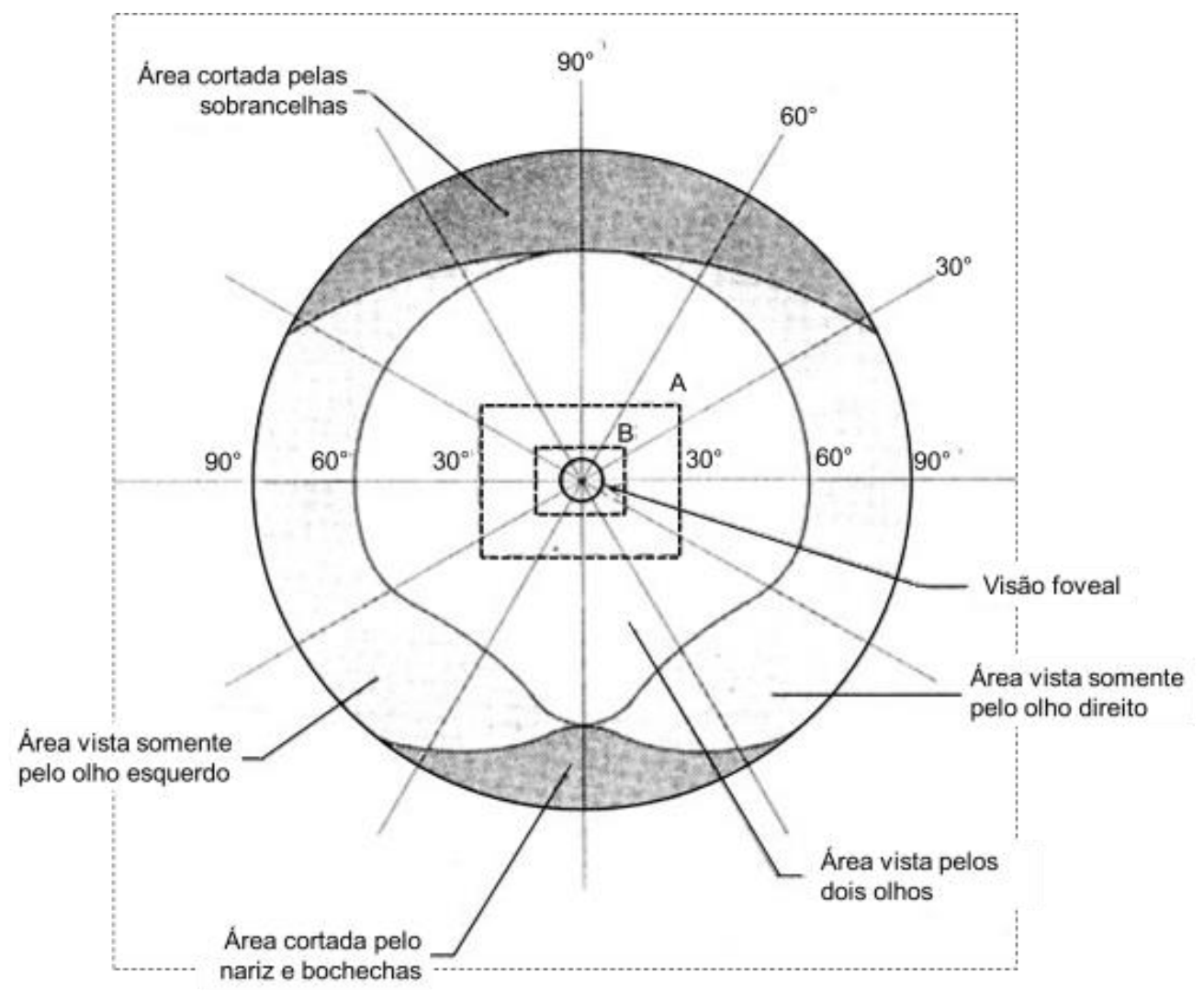

Figura C.10 - O campo de visão de um par de olhos normais. Os retângulos A e B sobrepostos no campo de visão podem representar um livro, uma revista ou um monitor (INKAROJRIT, 2005, p. 62). 
Para a interpretação de uma imagem, além dos ajustes físicos do sistema ocular (movimentos e focalização) a energia recebida da luz deve ser convertida em impulsos elétricos que chegam ao cérebro. Os fotorreceptores são os responsáveis para captar e transformar a energia luminosa em impulsos elétricos.

A retina contem duas classes principais de receptores, os cones e os bastonetes, que se diferenciam por sua morfologia e pela sensibilidade espectral dos fotos pigmentos que eles contem. A Figura C.11 ilustra, de maneira esquemática, as diversas camadas da retina.

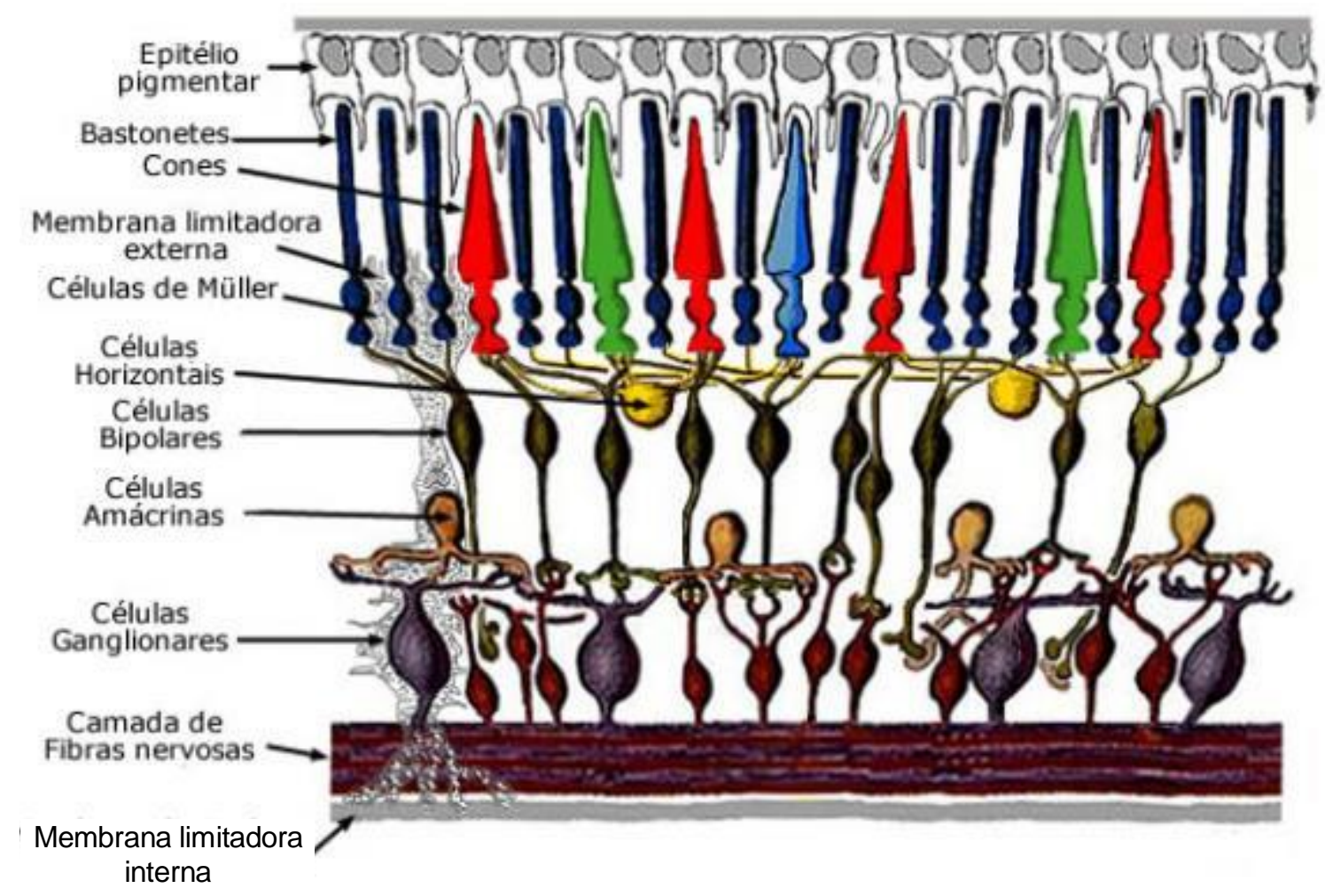

Figura C.11 Diagrama das conexões entre os elementos neurais na retina. A luz incidente está na parte inferior desse diagrama (membrana limitadora interna). Fonte: RUSS pág. 101

Os cones são divididos em três classes, cada uma delas contendo um foto pigmento diferente, sensível a comprimentos de onda curtos (S), com pico em torno de $420 \mathrm{~nm}$ (azul), médio (M) em torno de $530 \mathrm{~nm}$ (verde) ou longo (L) em torno de $558 \mathrm{~nm}$ (vermelho). Os cones estão concentrados na fóvea, embora haja cones em toda a retina, e os bastonetes têm maior concentração em um cone de $20^{\circ}$ em relação ao ponto cego, como pode ser visto na Figura C.12. O olho possui 65\% de cones sensíveis à luz vermelha, 33 sensíveis à luz verde e $2 \%$ sensíveis ao azul. A baixa 
quantidade de cones sensíveis ao azul é compensada pela maior sensibilidade desses cones em relação aos outros dois tipos.

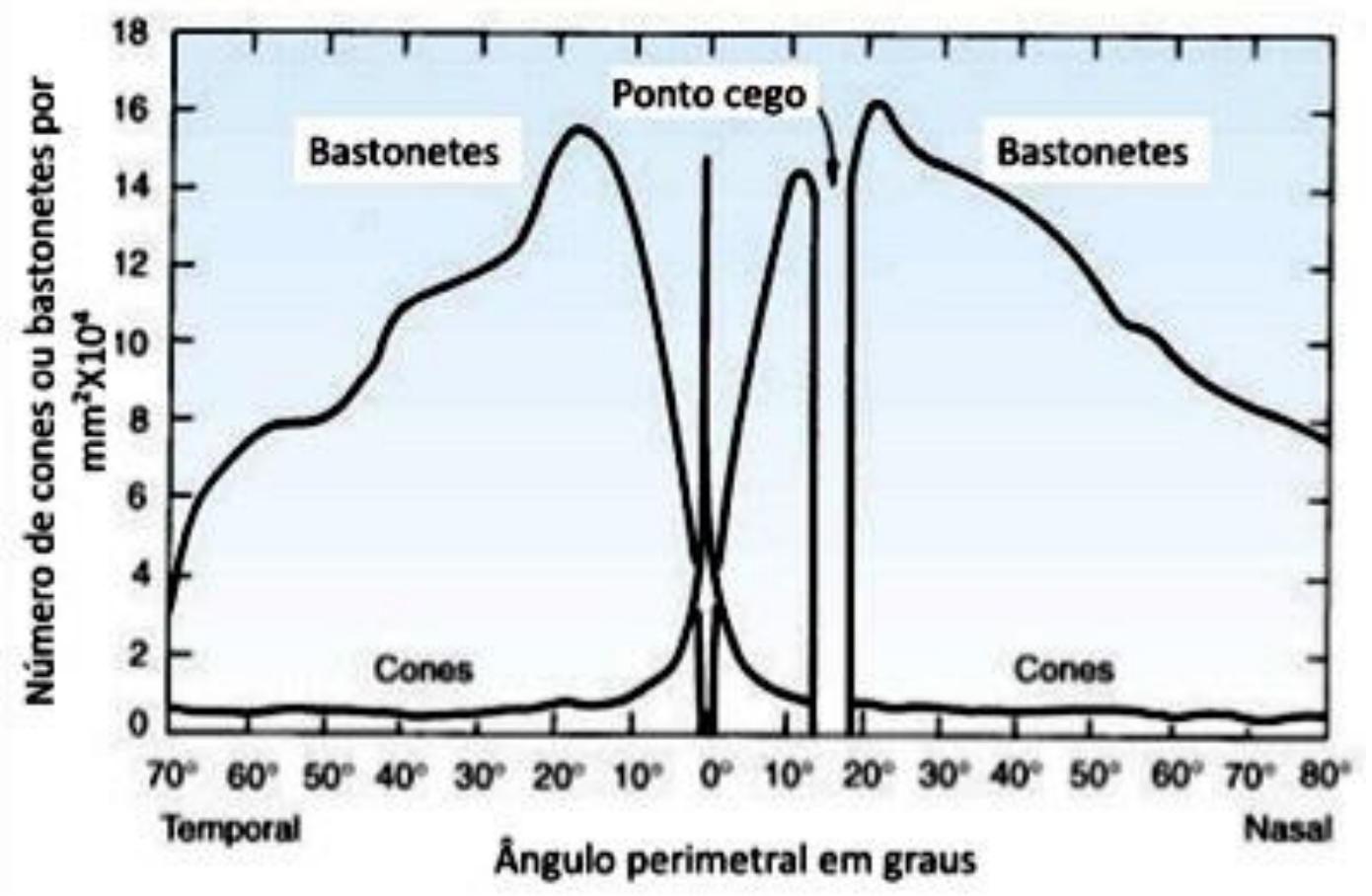

Figura C.12 Distribuição na retina dos cones e bastonetes. O ponto $0^{\circ}$ representa a fóvea

\section{Adaptação ao Claro e ao Escuro}

O trabalho eficiente do sistema visual implica em sua adaptação a várias condições de iluminação. Para lidar com as amplas variações de iluminação retinal, do escuro para luz solar, o sistema visual muda sua sensibilidade pelo processo chamado de adaptação, em que a abertura da pupila varia em função das condições de iluminação.

\section{Visão Fotópica, Escotópica e Mesópica}

O processo de visão varia em função das condições de Luminância dos objetos e da iluminação do ambiente. Esses processos são denominados por visão Fotópica, visão Escotópica e visão Mesópica. As curvas de sensibilidade espectrais relativas a esses tipos de visão são mostradas na Figura C.13. Essas curvas representam a sensibilidade relativa do olho humano em função do comprimento e de bastonetes (visão noturna - Escotópica) ou de cones (visão diurna - Fotópica). 
1. Visão Fotópica: ocorre para Luminâncias maiores do que $3 \mathrm{~cd} / \mathrm{m} 2$ (visão diurna), com utilização dos cones. Nesse tipo de visão as cores e detalhes dos objetos podem ser distinguidos.

2. Visão Escotópica: Ocorre para Luminâncias menores do que $0.001 \mathrm{~cd} / \mathrm{m} 2$ (visão noturna), com utilização dos bastonetes. Ao contrário da visão anterior, nesta, as cores não são percebidas.

3. Visão Mesópica: é a condição em que há combinação da visão Fotópica e Escotópica.

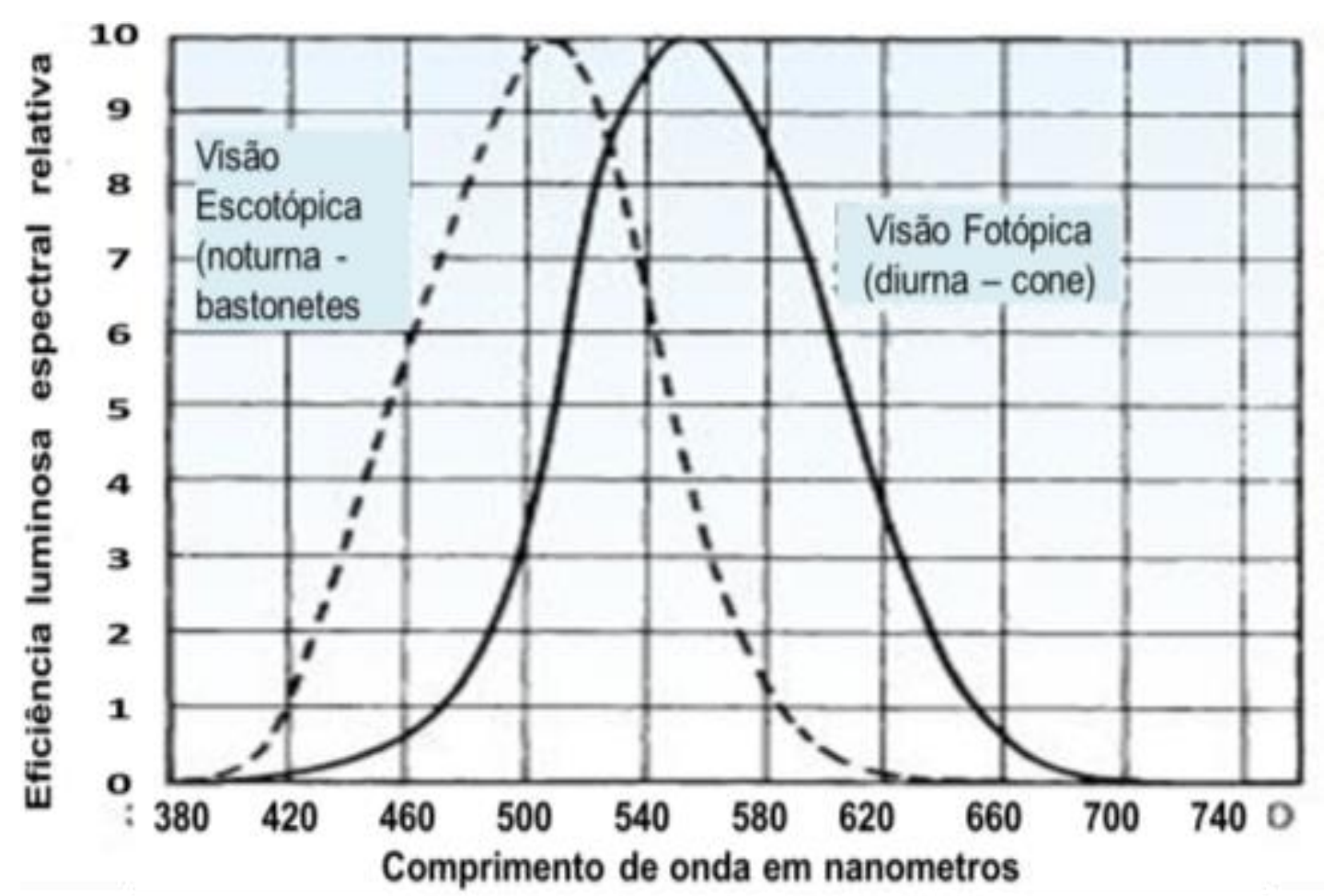

Figura C.13 - Curvas de sensibilidade espectral relativa do olho humano. IESNA (2000)

\section{Desempenho Visual, Desempenho de tarefa e Produtividade}

A análise dos processos de visão permitem entender o que ocorre nas diferentes situações de trabalho do ser humano. As diferentes tarefas executadas pelo homem, que dependem da visão, variam em função dos estímulos visuais absorvidos pelo sistema nervoso. Dessa maneira, o desempenho de determinada atividade terá maior ou menor eficiência, de acordo com a influência causada pelas condições de 
iluminação ambiental. Ao desenvolvermos tarefas que dependem da visão, estamos sujeitos a estímulos visuais que são absorvidos pelo sistema visual de forma que possamos executar tais tarefas com uma determinada eficiência. $O$ relacionamento conceitual entre estímulo visual, desempenho visual, desempenho da tarefa e produtividade é mostrado na Figura C.14. Nesta figura divide-se a execução da tarefe em 4 partes: estímulo visual, sistema visual, desempenho de tarefas e produtividade. Em cada parte são mostrados os componentes que afetam tal parte. As setas indicam os sentidos de seus efeitos para a execução de uma tarefa. Como exemplo, é apresentada uma seta tracejada, indicando se a desempenho visual for baixa deve-se alterar o estímulo visual aumentando-se o tamanho visual por aproximação ou por sistemas óticos.

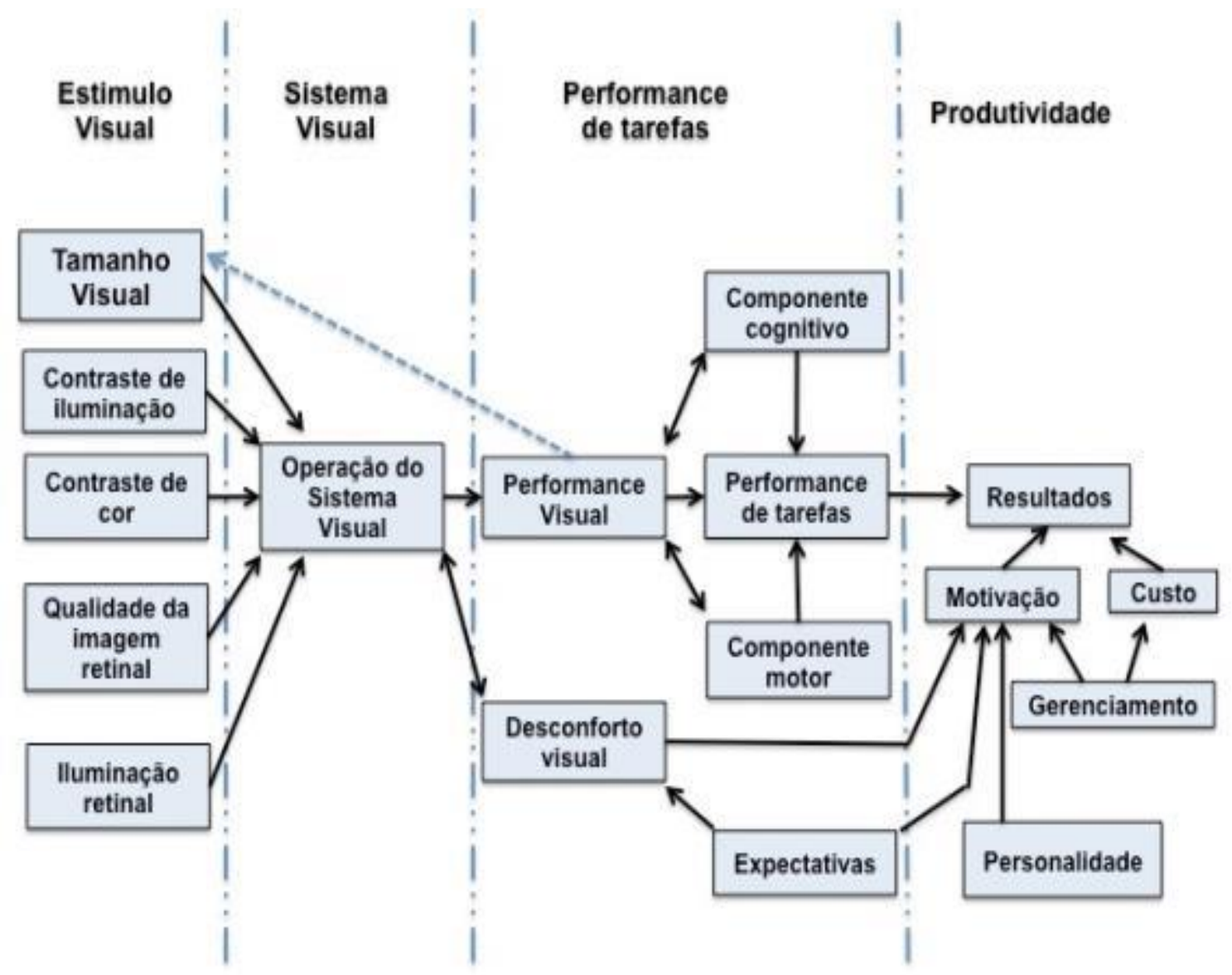

Figura C.14 - Diagrama do relacionamento entre os estímulos para o sistema visual e seus impactos no desempenho visual, desempenho de tarefa e produtividade (SALVENDY, 1997). 


\section{ANEXO 1 - Significado das cores em diferentes culturas}

A tabela abaixo mostra as variações dos significados das cores em função da região/pais/cultra

Tabela 2.3 baseada em "Color Meanings by Culture do site extraída do site "The International Business Edge"

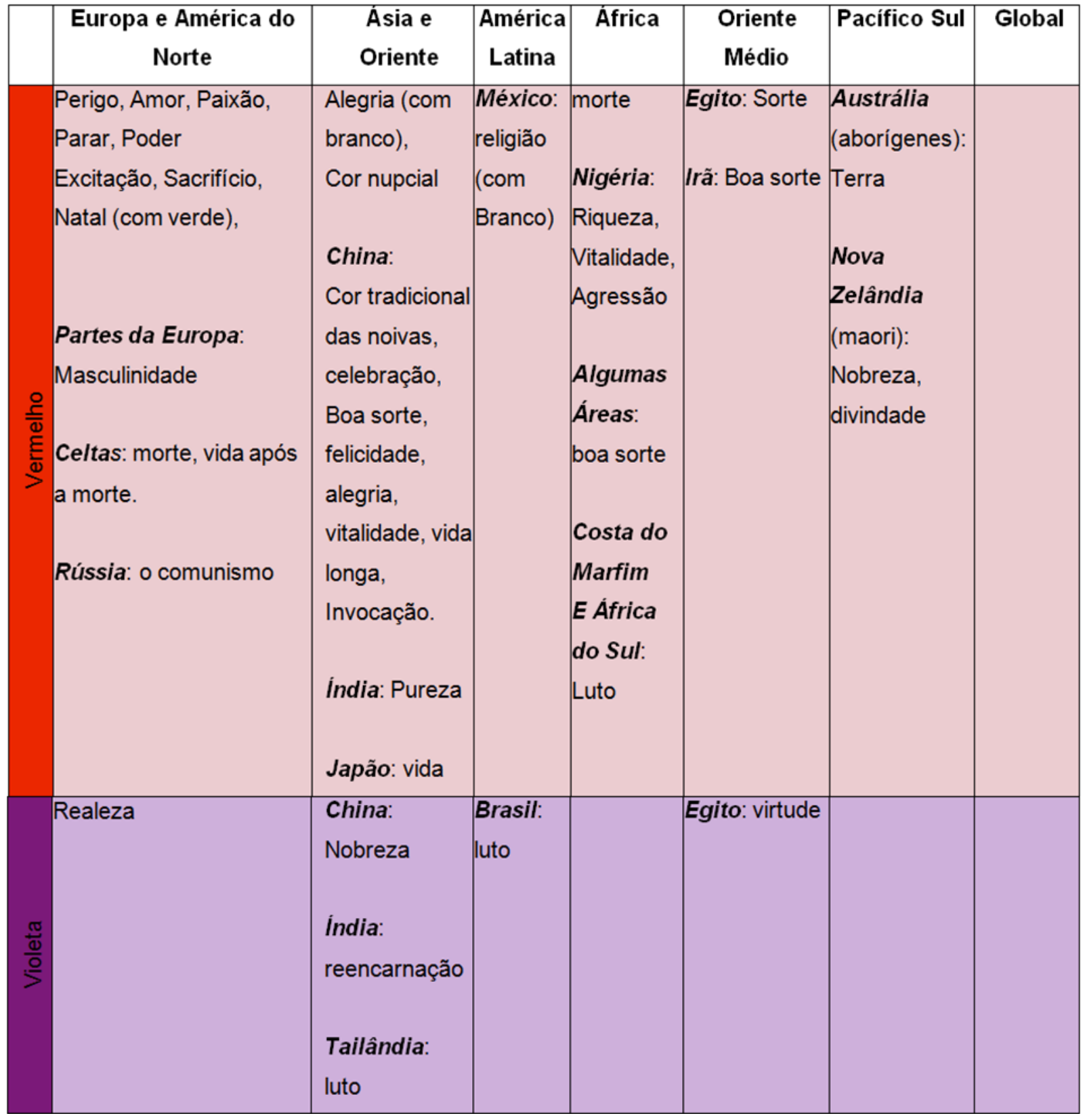


Continuação

\begin{tabular}{|c|c|c|c|c|c|c|c|}
\hline & $\begin{array}{c}\text { Europa e América do } \\
\text { Norte }\end{array}$ & $\begin{array}{l}\text { Ásia e } \\
\text { Oriente }\end{array}$ & $\begin{array}{c}\text { América } \\
\text { Latina }\end{array}$ & África & $\begin{array}{l}\text { Oriente } \\
\text { Médio }\end{array}$ & Pacifico Sul & Global \\
\hline & $\begin{array}{l}\text { Outono, colheita } \\
\text { Irlanda: os protestantes } \\
\text { Holanda: realeza (muito } \\
\text { popular) } \\
\text { Ucrânia: Força } \\
\text { Estados Unidos: dia das } \\
\text { bruxas (com preto) }\end{array}$ & $\begin{array}{l}\text { İndia (Hindu) } \\
\text { sagrado (a cor } \\
\text { açafrão) } \\
\text { Japão: } \\
\text { coragem, } \\
\text { amor }\end{array}$ & & & Egito: luto & & \\
\hline$\frac{\text { 인 }}{\frac{1}{20}}$ & $\begin{array}{l}\text { Esperança, Felicidade, } \\
\text { Covardia, } \\
\text { Fraqueza, Riscos, Taxis, } \\
\text { Calor } \\
\text { Alemanha: inveja } \\
\text { Itália: Verão } \\
\text { Ucrânia: Hospitalidade, } \\
\text { Benevolência }\end{array}$ & $\begin{array}{l}\text { Sagrado } \\
\text { Imperial } \\
\text { China: } \\
\text { Realeza, } \\
\text { nutritivo } \\
\text { India: } \\
\text { comércio } \\
\text { Japão: } \\
\text { Coragem }\end{array}$ & $\begin{array}{l}\text { México: } \\
\text { luto }\end{array}$ & $\begin{array}{l}\text { Etiópia: } \\
\text { Luto } \\
\text { África do } \\
\text { Sul (Zulu): } \\
\text { riquezas }\end{array}$ & $\begin{array}{l}\text { Egito: } \\
\text { luto } \\
\text { Arábia } \\
\text { Saudita: } \\
\text { força, } \\
\text { confiança }\end{array}$ & & \\
\hline & $\begin{array}{l}\text { Consciência Ambiental, } \\
\text { Primavera, Novo } \\
\text { Nascimento, Seguir, } \\
\text { Natal (com vermelho), } \\
\text { Dia de São Patrício } \\
\text { França: Não é uma boa } \\
\text { cor para embalagens } \\
\text { Irlanda: Cor Nacional, } \\
\text { catolicismo } \\
\text { Estados Unidos: } \\
\text { Dinheiro }\end{array}$ & $\begin{array}{l}\text { China: } \\
\text { Exorcismo, } \\
\text { Infidelidade } \\
\text { (Chapéus } \\
\text { verdes), não é } \\
\text { bom } \\
\text { Cor para } \\
\text { embalagens } \\
\text { India: } \\
\text { Islamismo } \\
\text { Japão: Vida, } \\
\text { Alta tecnologia }\end{array}$ & & $\begin{array}{l}\text { Norte da } \\
\text { África: } \\
\text { corrupção } \\
\text { África do } \\
\text { Sul } \\
\text { (Zulu): } \\
\text { Natureza }\end{array}$ & $\begin{array}{l}\text { Santidade } \\
\text { Egito: } \\
\text { cor nacional, } \\
\text { Fertilidade, } \\
\text { não é uma } \\
\text { boa cor para } \\
\text { embalagens }\end{array}$ & $\begin{array}{l}\text { Indonésia: } \\
\text { Cor proibida } \\
\text { Malásia e } \\
\text { Algumas } \\
\text { Áreas: } \\
\text { perigo }\end{array}$ & $\begin{array}{l}\text { Militaris- } \\
\text { mo }\end{array}$ \\
\hline
\end{tabular}

Continua 
Continuação

\begin{tabular}{|c|c|c|c|c|c|c|c|}
\hline & $\begin{array}{c}\text { Europa e América do } \\
\text { Norte }\end{array}$ & $\begin{array}{l}\text { Ásia e } \\
\text { Oriente }\end{array}$ & $\begin{array}{c}\text { América } \\
\text { Latina }\end{array}$ & África & $\begin{array}{l}\text { Oriente } \\
\text { Médio }\end{array}$ & Pacífico Sul & Global \\
\hline 胥 & $\begin{array}{l}\text { Escandinávia: limpeza } \\
\text { Ucrânia: boa saúde } \\
\text { Estados Unidos: bebês } \\
\text { meninos (azul claro), } \\
\text { usado por muitos bancos } \\
\text { para simbolizar a } \\
\text { confiança }\end{array}$ & $\begin{array}{l}\text { China: } \\
\text { imortalidade } \\
\text { India (hindu): } \\
\text { Krishna }\end{array}$ & $\begin{array}{l}\text { Colômbi } \\
\text { a: sabão }\end{array}$ & \begin{tabular}{|l|} 
Nigéria \\
(Yoruba): \\
muito \\
positivo \\
África do \\
Sul (Zulu): \\
alegria
\end{tabular} & $\begin{array}{l}\text { Protetivo } \\
\text { Irã: Paraiso, } \\
\text { imortalidade, } \\
\text { espirutualida } \\
\text { de }\end{array}$ & & $\begin{array}{l}\text { frequente } \\
\text { mente } \\
\text { considera } \\
\text { da a cor } \\
\text { mais } \\
\text { segura e } \\
\text { mais } \\
\text { positiva }\end{array}$ \\
\hline 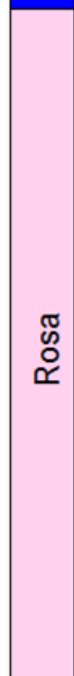 & Feminino & $\begin{array}{l}\text { casamento } \\
\text { Índia: } \\
\text { feminino } \\
\text { Japão: } \\
\text { Popular } \\
\text { para ambos os } \\
\text { sexos } \\
\text { Coréia: } \\
\text { Confiança }\end{array}$ & & $\begin{array}{l}\text { África do } \\
\text { Sul } \\
\text { (Zulu): } \\
\text { pobreza }\end{array}$ & & & \\
\hline 인 & $\begin{array}{l}\text { Funerais, morte, o luto, } \\
\text { Formalidade, Rebeldia }\end{array}$ & $\begin{array}{l}\text { China: Cor para } \\
\text { Meninos jovens, } \\
\text { confiança, alta } \\
\text { qualidade } \\
\text { Tailândia: má } \\
\text { sorte, } \\
\text { Infelicidade, o } \\
\text { mal } \\
\text { Tibet: o mal }\end{array}$ & $\begin{array}{l}\text { Peru, } \\
\text { Brasil: } \\
\text { luto, } \\
\text { Cor } \\
\text { preferida } \\
\text { para } \\
\text { roupa } \\
\text { masculi- } \\
\text { na }\end{array}$ & $\begin{array}{l}\text { Etiópia: } \\
\text { impuro, } \\
\text { desagra- } \\
\text { dável } \\
\text { Nigéria: } \\
\text { ameaçador }\end{array}$ & $\begin{array}{l}\text { Egito: } \\
\text { renascimento } \\
\text { Irã: luto }\end{array}$ & $\begin{array}{l}\text { Nova } \\
\text { Zelândia: cor } \\
\text { nacional } \\
\text { patriótico } \\
\text { Austrália } \\
\text { (aborígenes): } \\
\text { a cor do povo }\end{array}$ & \\
\hline
\end{tabular}

Continua 
Conclusão

\begin{tabular}{|c|c|c|c|c|c|c|c|}
\hline & $\begin{array}{c}\text { Europa e América do } \\
\text { Norte }\end{array}$ & $\begin{array}{l}\text { Ásia e } \\
\text { Oriente }\end{array}$ & $\begin{array}{c}\text { América } \\
\text { Latina }\end{array}$ & África & $\begin{array}{l}\text { Oriente } \\
\text { Médio }\end{array}$ & Pacifico Sul & Global \\
\hline 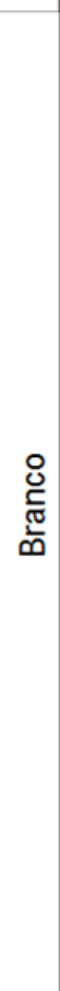 & $\begin{array}{l}\text { Casamento, paz, pureza, } \\
\text { Hospitais, Santidade } \\
\text { Itália: Morte e Funerais } \\
\text { (Crisântemo branco) }\end{array}$ & 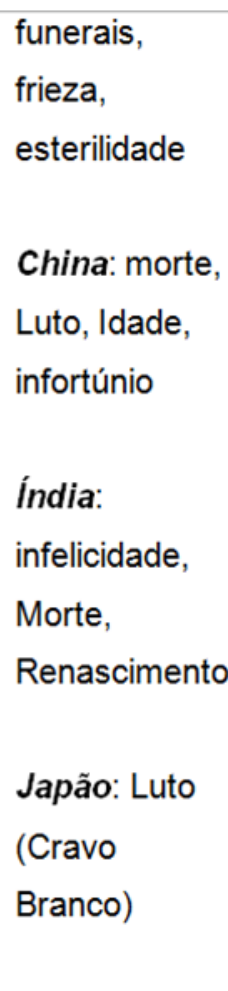 & & $\begin{array}{l}\text { Etiópia: } \\
\text { Doença, } \\
\text { Pureza } \\
\text { Nigéria: } \\
\text { Boa } \\
\text { Sorte, Paz } \\
\text { África do } \\
\text { Sul } \\
\text { (Zulu): } \\
\text { bondade } \\
\text { Zâmbia: } \\
\text { bondade, } \\
\text { Limpeza, } \\
\text { boa sorte }\end{array}$ & $\begin{array}{l}\text { Egito: Status } \\
\text { Irã: } \\
\text { santidade, } \\
\text { paz }\end{array}$ & $\begin{array}{l}\text { Nova Guiné: } \\
\text { prosperidade }\end{array}$ & \\
\hline $\begin{array}{l}\mathbb{N} \\
\frac{\mathbb{N}}{\mathrm{C}}\end{array}$ & Pobreza, Singeleza & & & & & $\begin{array}{l}\text { Papua Nova } \\
\text { Guiné: } \\
\text { luto }\end{array}$ & \\
\hline$\frac{\text { E }}{\text { Oे }}$ & $\begin{array}{l}\text { terrestre, saudável, } \\
\text { pobreza } \\
\text { Estados Unidos: muitas } \\
\text { vezes uma cor bem } \\
\text { sucedida para o } \\
\text { alimento } \\
\text { embalagens }\end{array}$ & Índia: Luto & $\begin{array}{l}\text { Colôm- } \\
\text { bia: } \\
\text { Desencor } \\
\text { aja } \\
\text { Vendas } \\
\text { Nicará- } \\
\text { gua: } \\
\text { Desapro- } \\
\text { ação }\end{array}$ & & $\begin{array}{l}\text { Austrália } \\
\text { (aborígenes): } \\
\text { Cor da Terra }\end{array}$ & & \\
\hline$\frac{\pi}{\frac{\pi}{0}}$ & Dinheiro, elegante & & & & & & \\
\hline 음 & & & & & & & $\begin{array}{l}\text { dinheiro, } \\
\text { sucesso, } \\
\text { alta } \\
\text { qualidade }\end{array}$ \\
\hline
\end{tabular}

